\title{
The investigative function of the European parliament : holding the EU executive to account by conducting investigations
}

Citation for published version (APA):

Syrier, C. N. (2013). The investigative function of the European parliament : holding the EU executive to account by conducting investigations. [Doctoral Thesis, Maastricht University]. Wolf Legal Publishers. https://doi.org/10.26481/dis.20130411cs

Document status and date:

Published: 01/01/2013

DOI:

10.26481/dis.20130411cs

Document Version:

Publisher's PDF, also known as Version of record

\section{Please check the document version of this publication:}

- A submitted manuscript is the version of the article upon submission and before peer-review. There can be important differences between the submitted version and the official published version of record.

People interested in the research are advised to contact the author for the final version of the publication, or visit the DOI to the publisher's website.

- The final author version and the galley proof are versions of the publication after peer review.

- The final published version features the final layout of the paper including the volume, issue and page numbers.

Link to publication

\footnotetext{
General rights rights.

- You may freely distribute the URL identifying the publication in the public portal. please follow below link for the End User Agreement:

www.umlib.nl/taverne-license

Take down policy

If you believe that this document breaches copyright please contact us at:

repository@maastrichtuniversity.nl

providing details and we will investigate your claim.
}

Copyright and moral rights for the publications made accessible in the public portal are retained by the authors and/or other copyright owners and it is a condition of accessing publications that users recognise and abide by the legal requirements associated with these

- Users may download and print one copy of any publication from the public portal for the purpose of private study or research.

- You may not further distribute the material or use it for any profit-making activity or commercial gain

If the publication is distributed under the terms of Article $25 \mathrm{fa}$ of the Dutch Copyright Act, indicated by the "Taverne" license above, 


\section{THE INVESTIGATIVE FUNCTION OF THE EUROPEAN PARLIAMENT}

Holding the EU executive to account by conducting investigations

Christian Syrier

ฟ 
The investigative function of the European Parliament

Holding the EU executive to account by conducting investigations

Christian Syrier

ISBN: 978-90-5850-959-8

Published by:

ฟolf Legal Publishers (WLP)

PO Box 313

5060 AH Oisterwijk

The Netherlands

E-Mail: info@wolfpublishers.nl

www.wolfpublishers.com

All rights reserved. No part of this publication may be reproduced, stored in a retrieval system, or transmitted in any form or by any means, electronic, mechanical, photocopying, recording or otherwise, without prior written permission of the publisher. Whilst the authors, editors and publisher have tried to ensure the accuracy of this publication, the publisher, authors and editors cannot accept responsibility for any errors, omissions, misstatements, or mistakes and accept no responsibility for the use of the information presented in this work.

(C) The Author, 2013 


\section{THE INVESTIGATIVE FUNCTION OF THE EUROPEAN PARLIAMENT}

\section{Holding the EU executive to account by conducting investigations}

\section{Proefschrift}

ter verkrijging van de graad van doctor aan de

Universiteit Maastricht,

op gezag van de Rector Magnificus, prof. dr. L.L.G. Soete,

volgens het besluit van het College van Decanen, in het openbaar te verdedigen op

donderdag 11 april 2013 om 14.00 uur

door

Christian Nicolas Syrier 
Promotiecommissie

Promotores

Prof. mr. L.F.M. Verhey

Prof. dr. E.I.L. Vos

Beoordelingscommissie

Prof. dr. B. de Witte (voorzitter)

Prof. dr. J.Th.J. van den Berg

Prof. dr. mr. M.A.P. Bovens (Universiteit Utrecht)

Prof. dr. M.L.H.K. Claes

Prof. dr. W.J.M. Voermans (Universiteit Leiden)

This research project is subsidized by the Montesquieu Institute. 
voor mïn ouders 



\section{ACKNOWLEDGEMENTS}

In summer 2007 Luc Verhey asked me whether I was interested in writing a doctoral thesis in Maastricht. "Yes I am", was my answer, "but first I would like to go to Berlin for a study period". I am grateful that Luc agreed. After six great months in Berlin I spent four pleasant years writing my doctoral thesis at the law faculty of Maastricht University. I would like to extend my sincere thanks to everyone who contributed.

First of all I am thankful to my supervisors, Luc Verhey and Ellen Vos, for the congenial and inspiring guidance and for the freedom they gave me while writing my thesis. In this case, 'freedom' is definitely not a euphemism for indifference. Quite the contrary; I cherish fond memories of our discussions and I am sure that we will meet again in the future. I am grateful to Bruno de Witte, Joop van den Berg, Mark Bovens, Monica Claes and Wim Voermans, who have not only agreed to sit on the thesis committee, but who have also provided valuable comments on the manuscript. My thanks also go to the Montesquieu Institute for financing the doctoral project and to the 'Verfassung jenseits des Staates' graduate school at the Humboldt University in Berlin, where I spent five months in 2010 conducting my research in an inspiring environment, quite literally 'Unter den Linden'.

Furthermore, I would like to thank my former colleagues at the law faculty of Maastricht University for making the time I spent writing this thesis very agreeable. Special thanks go to the colleagues at 'jong publiekrecht' with whom I spent numerous coffee breaks and lunches. Particular thanks go to Danielle and my former roommate Mira.

As of April 2012, I have been working with great pleasure at the Dutch Ministry of Security and Justice in The Hague. I am particularly grateful to the head of Constitutional and Administrative Law of the Directorate of Legislation and Legal Affairs, Anneke van Dijk, for giving me the opportunity to finalize my thesis.

As a matter of course, life has much more to offer than just work. I am lucky to have family and friends who are always there if I need them. Special thanks go to my parents, Remy and Adje, to my brothers, Gilles and Raoul, to Meryl, and - last but definitely not least - to my great friends, of which I mention my 'paranymphs' Tim and Tum in particular.

The Hague, 27 December 2012. 


\section{TABLE OF CONTENTS}

1. INTRODUCTION 1

1.1 Introduction 1

1.2 The alleged accountability deficit in the EU 2

1.3 The concept of accountability 3

1.4 Holding the executive to account by conducting investigations 8

$\begin{array}{lll}1.5 & \text { Research questions and methodology } & 11\end{array}$

2. INVESTIGATIONS BY TEMPORARY COMMITTEES OF INQUIRY 13

$\begin{array}{lll}2.1 & \text { Introduction } & 13\end{array}$

$\begin{array}{ll}2.2 & \text { The right of inquiry prior to Maastricht } \\ \end{array}$

$\begin{array}{lll}2.3 & \text { The right of inquiry since Maastricht; legal framework } & 18\end{array}$

2.4 Proceedings and powers of committees of inquiry 24

2.5 The right of inquiry in practice: inquiries since 1993

2.6 The future shape of the right of inquiry 112

$\begin{array}{lll}2.7 & \text { Conclusion } & 123\end{array}$

3. INVESTIGATIONS BY TEMPORARY SPECIAL COMMITTEES 129

$\begin{array}{lll}3.1 & 129\end{array}$

$\begin{array}{lll}3.2 & \text { Special committees prior to Maastricht } & 129\end{array}$

$\begin{array}{ll}3.3 & \text { Special committees since Maastricht; legal framework }\end{array}$

$\begin{array}{lll}3.4 & \text { Proceedings of special committees } & 133\end{array}$

3.5 Practice of special committees since $1993 \quad 136$

$\begin{array}{ll}3.6 & \text { Accountability investigations by special committees } \\ 3.7 & 149\end{array}$

$\begin{array}{lll}3.7 & \text { Gathering of information } & 183\end{array}$

$\begin{array}{lll}3.8 & \text { Conclusion } & 187\end{array}$

4. INVESTIGATIONS BY STANDING COMMITTEES 191

$\begin{array}{lll}4.1 & \text { Introduction } & 191\end{array}$

4.2 Standing committees of the European Parliament 192

$\begin{array}{lll}4.3 & \text { Gathering information: legal procedures and informal practices } & 197\end{array}$

4.4 Accountability investigations by special committees 203

$\begin{array}{lll}4.5 & \text { Conclusion } & 224\end{array}$

$\begin{array}{lll}\text { 5. CONCLUSION } & 227\end{array}$

$\begin{array}{lll}5.1 & \text { Three types of committees } & 227\end{array}$

$5.2 \quad$ Formal investigative powers; status quo and future perspectives 231

5.3 Beyond formal powers; incentives to investigate and to cooperate 236

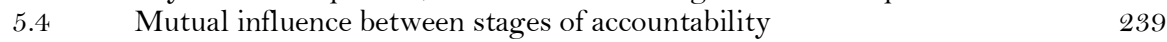

5.5 Strengthening the investigative function of the Parliament 240

$\begin{array}{lll}5.6 & \text { Outlook } & 245\end{array}$

$\begin{array}{ll}\text { SAMENVATTING } & 251\end{array}$

$\begin{array}{ll}\text { BIBLIOGRAPHY } & 257\end{array}$

$\begin{array}{ll}\text { CURRICULUM VITAE } & 271\end{array}$ 


\section{TABLE OF CONTENTS (EXTENDED)}

1. INTRODUCTION 1

1.1 INTRODUCTION 1

1.2 The alleged accountability Deficit In The EU 2

1.3 The CONCEPT OF ACCOUNTABILITY 3

1.3.1 Defining accountability 3

1.3.2 Purposes of accountability 4

1.3.2.1 Direct purposes of accountability 4

1.3.2.2 Indirect purposes of accountability 6

$\begin{array}{lll}\text { 1.3.3 Three accountability stages } & 7\end{array}$

1.4 Holding The EXECUTIVE TO ACCOUNT By CONDUCTING INVESTIGATIONS 8

1.4.1 Political accountability 8

1.4.2 The EU executive as actor and the European Parliament as forum 8

1.4.3 Parliamentary investigations as an accountability instrument 9

$\begin{array}{ll}\text { 1.4.3.1 Accountability investigations } & 10\end{array}$

$\begin{array}{ll}\text { 1.4.3.2 Non-accountability investigations } & 10\end{array}$

$\begin{array}{ll}\text { 1.4.3.3 Object of research: accountability investigations } & 11\end{array}$

$\begin{array}{lll}1.5 & \text { ReSEARCH QUESTIONS AND METHODOLOGY } & 11\end{array}$

2. INVESTIGATIONS BY TEMPORARY COMMITTEES OF INQUIRY 13

$\begin{array}{lll}2.1 & \text { INTRODUCTION } & 13\end{array}$

2.2 The RIGHT OF INQUIRY PRIOR TO MAASTRICHT $\quad 15$

2.3 ThE RIGHT OF INQUIRY SINCE MAASTRICHT; LEGAL FRAMEWORK 18

2.3.1 Article 226 TFEU 18

$\begin{array}{ll}\text { 2.3.2 Interinstitutional Agreement } & 19\end{array}$

2.3.3 Rules of Procedure of the European Parliament 21

2.3.4 Legal status of the arrangements 22

$\begin{array}{ll}\text { 2.3.5 Duty of sincere cooperation } & 23\end{array}$

2.4 ProceEdings AND POWERS OF COMMITTEES OF INQUiRY 24

2.4.1 Chronological proceedings 24

2.4.2 Establishment and composition of committees of inquiry 26

$\begin{array}{ll}\text { 2.4.2.1 Quorum } & 26\end{array}$

$\begin{array}{lll}\text { 2.4.2.2 Formal requirements } & 27\end{array}$

2.4.2.3 Duration of inquiries $\quad 27$

2.4.2.4 Composition of committees of inquiry 28

$\begin{array}{ll}\text { 2.4.2.5 Staff of committees } & 28\end{array}$

2.4.3 Scope of the right of inquiry $\quad 29$

$\begin{array}{ll}\text { 2.4.3.1 Object of investigation } & 29\end{array}$

2.4.3.2 Subject of investigation 34

2.4.4 Powers of committees of inquiry $\quad 35$

2.4.4.1 The right to call witnesses $\quad 35$

$\begin{array}{ll}\text { 2.4.4.2 Legal position of witnesses } & 40\end{array}$

$\begin{array}{ll}\text { 2.4.4.3 Access to documents } & 43\end{array}$

$\begin{array}{ll}\text { 2.4.4.4 Fact-finding visits } & 45\end{array}$

2.4.4.5 Sanctions 46

2.4.5 Legal protection in the course of inquiries 49

2.4.5.1 Legal protection against the establishment of a committee of inquiry $\quad 49$ 
2.4.5.2 Legal protection against acts of committees of inquiry 51

2.4.6 Inquiry outcomes and follow-up 52

2.5 THE RIGHT OF INQUIRY IN PRACTICE: INQUIRIES SINCE 1993

2.5.1 Inquiry into the Community Transit System 55

2.5.1.1 Subject, establishment and duration of the inquiry $\quad 55$

$\begin{array}{lr}\text { 2.5.1.2 Inquiry proceedings } & 56\end{array}$

$\begin{array}{ll}\text { 2.5.1.3 The committee's final report } & 60\end{array}$

2.5.1.4 Chairman's evaluation of the committee's working methods 64

2.5.1.5 Plenary debate of 12 March $1997 \quad 66$

$\begin{array}{lll}\text { 2.5.1.6 Follow-up to the inquiry } & 67\end{array}$

$\begin{array}{ll}\text { 2.5.2 Inquiry into BSE } & 69\end{array}$

2.5.2.1 Subject, establishment and duration of the inquiry 69

$\begin{array}{ll}\text { 2.5.2.2 Concurrence with judicial investigations } & 70\end{array}$

$\begin{array}{ll}\text { 2.5.2.3 Inquiry proceedings } & 72\end{array}$

$\begin{array}{ll}\text { 2.5.2.4 The committee's final report } & 78\end{array}$

2.5.2.5 Chairman's evaluation of the committee's working methods 82

2.5.2.6 Plenary debate of 18 February $1997 \quad 84$

$\begin{array}{lll}\text { 2.5.2.7 Follow-up to the inquiry } & 86\end{array}$

2.5.3 Inquiry into the crisis of the Equitable Life Assurance Society 88

$\begin{array}{ll}\text { 2.5.3.1 Subject, establishment and duration of the inquiry } & 88\end{array}$

$\begin{array}{ll}\text { 2.5.3.2 Inquiry proceedings } & 90\end{array}$

$\begin{array}{ll}\text { 2.5.3.3 The committee's final report } & 95\end{array}$

$\begin{array}{ll}\text { 2.5.3.4 The role of committees of inquiry } & 97\end{array}$

$\begin{array}{ll}\text { 2.5.3.5 Plenary debate of } 19 \text { June } 2007 & 101\end{array}$

$\begin{array}{lll}\text { 2.5.3.6 Follow-up to the inquiry } & 102\end{array}$

2.5.4 Assessment of the parliamentary inquiries held since $1993 \quad 103$

$\begin{array}{ll}\text { 2.5.4.1 Gathering of evidence } & 103\end{array}$

$\begin{array}{ll}\text { 2.5.4.2 Three inquiries, one working method? } & 106\end{array}$

$\begin{array}{ll}\text { 2.5.4.3 Legal limitations in practice } & 107\end{array}$

2.5.4.4 The fall of the Santer Commission: a missed opportunity? 111

$\begin{array}{ll}2.6 & \text { THE FUTURE SHAPE OF THE RIGHT OF INQUIRY } \\ & 112\end{array}$

2.6.1 Should the right of inquiry be strengthened? 113

$\begin{array}{ll}\text { 2.6.2 Proposed modifications to the right of inquiry } & 115\end{array}$

$\begin{array}{ll}\text { 2.6.2.1 The scope of the right of inquiry } & 116\end{array}$

$\begin{array}{ll}\text { 2.6.2.2 The powers of committees of inquiry } & 117\end{array}$

2.6.2.3 Legal protection in the course of inquiries 120

2.6.2.4 Remarks on the proposed modifications 120

$\begin{array}{lll}2.7 & \text { Conclusion } & 123\end{array}$

3. INVESTIGATIONS BY TEMPORARY SPECIAL COMMITTEES 129

$\begin{array}{llr}3.1 & \text { INTRODUCTION } & 129\end{array}$

$\begin{array}{lll}3.2 & \text { SPECIAL COMMITTEES PRIOR TO MAASTRICHT } & 129\end{array}$

3.3 SPECIAl COMmittees Since MaAstricht; LEgal Framework 130

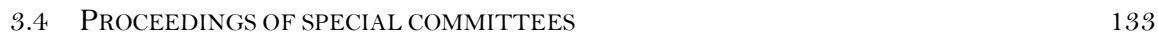

$\begin{array}{lll}\text { 3.4.1 Chronological proceedings } & 133\end{array}$

3.4.2 Individual aspects of the investigations 134

$\begin{array}{ll}\text { 3.4.2.1 Duration of investigations } & 134\end{array}$

3.4.2.2 Committee meetings 134

3.4.2.3 Bureau, rapporteur, coordinators, and shadow rapporteurs $\quad 135$ 
3.4.2.4 The role of the rapporteur $\quad 135$

$\begin{array}{ll}\text { 3.4.2.5 Committee staff } & 136\end{array}$

3.4.2.6 Minority opinions 136

3.5 PRACTICE OF SPECIAL COMMITTEES SINCE $1993 \quad 136$

$\begin{array}{lll}3.5 .1 & \text { Employment (1994-1995) } & 137\end{array}$

$\begin{array}{lll}\text { 3.5.2 BSE follow-up (1997) } & 137\end{array}$

$\begin{array}{lll}3.5 .3 & \text { Echelon (2000-2001) } & 138\end{array}$

3.5.4 Human genetics (2001) 140

3.5.5 Foot-and-mouth disease (2002) 141

3.5.6 Improving safety at sea (2003-2004) 142

3.5.7 Policy challenges and budgetary means of the enlarged Union 2007-2013 (2003-

2004) 143

3.5.8 CIAflights (2006-2007) 144

3.5.9 Climate change (2007-2008) 145

3.5.10 Financial, economic, and social crisis (2009-2010) 146

3.5.1 1 Policy Challenges and Budgetary Resources for a Sustainable European Union after 2013 (2010-2011) 146

$\begin{array}{lll}3.5 .12 & \text { Organized crime, corruption and money laundering } & 147\end{array}$

$\begin{array}{ll}\text { 3.5.13 Types of investigation: concluding remarks } & 147\end{array}$

3.6 ACCOUNTABILITY INVESTIGATIONS BY SPECIAL COMMITTEES 149

$\begin{array}{lll}\text { 3.6.1 BSE follow-up } & 149\end{array}$

3.6.1.1 Subject, establishment and duration of the investigation 149

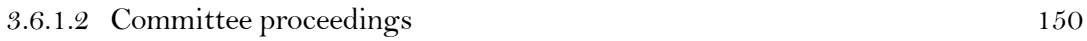

3.6.1.3 The committee's final report 152

3.6.1.4 Plenary debate of 18 November 1997

3.6.1.5 Follow-up to the investigation 155

$\begin{array}{ll}\text { 3.6.2 Echelon } & 156\end{array}$

3.6.2.1 Subject, establishment and duration of the investigation 156

$\begin{array}{ll}\text { 3.6.2.2 Committee proceedings } & 157\end{array}$

3.6.2.3 The committee's final report 161

3.6.2.4 Plenary debate of 5 September 2001

3.6.2.5 Follow-up to the investigation 164

$\begin{array}{lll}\text { 3.6.3 Foot-and-mouth disease } & 165\end{array}$

3.6.3.1 Subject, establishment and duration of the investigation 165

3.6.3.2 Committee proceedings 165

3.6.3.3 The committee's final report 167

$\begin{array}{ll}\text { 3.6.3.4 Plenary debate of } 17 \text { December } 2002 & 167\end{array}$

$\begin{array}{ll}\text { 3.6.3.5 Follow-up to the investigation } & 168\end{array}$

$\begin{array}{ll}\text { 3.6.4. Improving safety at sea } & 169\end{array}$

3.6.4.1 Subject, establishment and duration of the investigation 169

$\begin{array}{ll}\text { 3.6.4.2 Committee proceedings } & 170\end{array}$

3.6.4.3 The committee's final report 172

3.6.4.4 Plenary debate of 20 April 2004 174

$\begin{array}{ll}\text { 3.6.4.5 Follow-up to the investigation } & 175\end{array}$

$\begin{array}{lll}\text { 3.6.5 CIAflights } & 175\end{array}$

3.6.5.1 Subject, establishment and duration of the investigation $\quad 175$

$\begin{array}{ll}\text { 3.6.5.2 Committee proceedings } & 177\end{array}$

$\begin{array}{ll}\text { 3.6.5.3 The committee's final report } & 179\end{array}$

3.6.5.4 Plenary debate of 14 February $2007 \quad 182$ 
3.6.5.5 Follow-up to the investigation 183

$\begin{array}{lll}3.7 & \text { GATHERING OF INFORMATION } & 183\end{array}$

$\begin{array}{lll}\text { 3.7.1 Oral information } & 183\end{array}$

$\begin{array}{ll}3.7 .2 & \text { Written information } \\ 3.7 .385\end{array}$

$\begin{array}{lll}3.7 .3 & \text { Fact-finding visits } & 186\end{array}$

$\begin{array}{llr}3.8 & \text { CONCLUSION } & 187\end{array}$

4. INVESTIGATIONS BY STANDING COMMITTEES 191

$\begin{array}{lll}4.1 & \text { INTRODUCTION } & 191\end{array}$

$\begin{array}{lll}4.2 & \text { Standing committees of the European Parliament } & 192\end{array}$

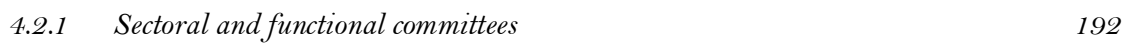

4.2.2 Committee members 194

4.2.3 Committee bureaux 194

4.2.4 Rapporteurs, draftspersons and shadow rapporteurs 195

$\begin{array}{lll}\text { 4.2.5 Group coordinators } & 195\end{array}$

$\begin{array}{lll}\text { 4.2.6 Committee staff } & 196\end{array}$

4.2.7 Own-initiative reports 196

4.3 GATHERING OF INFORMATION: LEGAL PROCEDURES AND INFORMAL PRACTICES 197

$\begin{array}{lll}\text { 4.3.1 European Commission } & 197\end{array}$

$\begin{array}{lll}\text { 4.3.2 European Council } & 199\end{array}$

4.3.3 Council of the European Union 200

4.3.4 European Central Bank 201

4.3.5 EU agencies 202

4.4 ACCOUNTABILITY INVESTIGATIONS BY STANDING COMMITTEES 203

$\begin{array}{lll}\text { 4.4.1 Inquiry-type investigations } & 204\end{array}$

$\begin{array}{ll}\text { 4.4.2 Investigations following petitions } & 207\end{array}$

4.4.3 Investigations in the course of the discharge procedure 210

4.4.3.1 Timetable of the discharge procedure 211

4.4.3.2 Holding the executive to account through the discharge procedure 212

4.4.3.3 Discharge to the Commission 214

4.4.3.4 Discharge to EU agencies: two case studies 216

4.4.4 Investigations regarding the implementation of EU legislation 221

$\begin{array}{lll}4.5 & \text { Conclusion } & 224\end{array}$

$\begin{array}{lll}\text { 5. CONCLUSION } & 227\end{array}$

$\begin{array}{lll}5.1 & \text { Three TyPes OF COMMITTEeS } & 227\end{array}$

5.2 Formal INVESTIGATIVE POWERS; STATUS QUO AND FUTURE PERSPECTIVES 231

5.3 BEYOND FORMAL POWERS; INCENTIVES TO INVESTIGATE AND TO COOPERATE 236

5.4 Mutual Influence BetWeEn Stages OF ACCOUNTABility 239

5.5 Strengthening the investigative function of the Parliament 240

$\begin{array}{lll}5.6 & \text { OUTLOOK } & 245\end{array}$

$\begin{array}{ll}\text { SAMENVATTING } & 251\end{array}$

$\begin{array}{ll}\text { BIBLIOGRAPHY } & 257\end{array}$

$\begin{array}{ll}\text { CURRICULUM VITAE } & 271\end{array}$ 


\section{INTRODUCTION}

\subsection{Introduction}

"Pour qu'on ne puisse abuser du pouvoir, il faut que, par la disposition des choses, le pouvoir arrête le pouvoir"

Charles de Montesquieu (1689-1755), De l'Esprit des Lois (1748)

Montesquieu articulated his famous theory on the separation of powers with a view to preventing the abuse of state power. Separation of powers, he argued, requires not only a division of the legislative, executive and judicial powers (the trias politica), but also a balance between these three powers. Both power and countervailing power are needed to prevent one from dominating the other. One way of organizing such countervailing powers - hereafter referred to as 'checks and balances' - is the establishment of accountability relationships between the three powers. In Western democracies this implies inter alia that the executive branch of a government is bound by the law, and as such it is legally accountable to the judiciary branch. Furthermore, notably in parliamentary democracies, the executive branch is politically accountable to the legislative branch. These accountability relationships aim to prevent the abuse of executive power.

Although theories on the separation of powers might change according to developments in society and politics, the spirit of Montesquieu's doctrine is still topical today. This is particularly true for the European Union, where power is said to escape accountability due to a lack of proper checks and balances. Accountability deficits are said to exist and even to be growing, as a result of which some commentators claim that the democratic legitimacy of the polity of the European Union has been compromised. ${ }^{1}$

Accountability is a central theme in this book. The book concentrates on the European Parliament as a forum that holds EU executive actors to account. The European Parliament has several means to hold EU executive actors to account. Well-known instruments include the right to put questions to executive actors and the right to debate specific issues with them. This study is limited to one particular instrument which the Parliament may use to hold the executive to account, namely parliamentary investigations. The Treaty on the Functioning of the European Union (hereafter: the TFEU) grants the European Parliament a specific tool to organize such investigations: the right of inquiry. Article 226 TFEU stipulates that the European Parliament may establish temporary committees of inquiry to investigate 'alleged contraventions or maladministration in the implementation of Union law'. Like their counterparts in most EU Member States, temporary committees of inquiry of the European Parliament have special powers to conduct investigations. They may, for example, invite witnesses and request access to

${ }^{1}$ Cf. Curtin (2004), p. 14 and further; Bovens (2007), p. 447; Arnull/Wincott (2002), p. 1; Harlow (2002), p. 168 and further; Papadopoulos (2007), p. 470. 
documents. The European Parliament has used its right of inquiry rather prudently. Since 1993, when the right of inquiry was for the first time recognized as primary EU law, the Parliament has only set up three committees of inquiry. Chalmers has noted that the European Parliament committees of inquiry have yet to become the key players in securing greater accountability in the European Union that they were promised to be.. ${ }^{2}$ In addition to its temporary committees of inquiry, the European Parliament investigates executive action through its standing committees and its other temporary committees (the so-called 'special committees'). This book discusses the investigative activities of committees of inquiry, temporary 'special committees', and standing committees.

\subsection{The alleged accountability deficit in the EU}

"The temptation to deprive the concept of responsibility of all substance is a dangerous one. That concept is the ultimate manifestation of democracy". ${ }^{3}$ With these famous words, a Committee of Independent Experts finished its devastating first report on allegations of fraud, mismanagement and nepotism in the European Commission in 1999. The Committee's conclusion, that within the European Commission "it is becoming difficult to find anyone who has even the slightest sense of responsibility" ", symbolized the critical situation of democratic governance in the European Union. The democratic quality of the European polity is a constant subject of criticism. The most frequently heard reproach is that the European Union is considered by its citizens to have a low level of legitimacy, and that there is a 'democratic deficit' in the European decision-making process. The former was most clearly expressed by the 'No' votes in the European Constitution referenda in France and the Netherlands in 2005 and the 'No' in the Irish referendum on the Reform Treaty of Lisbon in 2008. The latter - the 'democratic deficit' - is a reference to democratic problems in the EU polity. Claims of this democratic deficit usually cite the erosion of representative democracy as a consequence of executive dominance. This executive dominance has its origins in the fact that the transfer of national executive competences to the EU level has not been matched by an equivalent increased intensity of parliamentary supervision over the exercise of these executive powers. ${ }^{5}$ National parliaments experience difficulties in exercising effective scrutiny of their governments in EU matters. The European Parliament alleviates this problem by providing a directly elected forum at the EU level, but is - so the argument goes - not able to solve it because of inter alia the lack of voter interest in its elections, because of the absence of a developed party system on the EU level and because of the limited formal powers with regard to the formation of the EU executive. ${ }^{6}$ Majone puts the claims of a democratic deficit somewhat in perspective. According to him, the real problem is the 'accountability deficit', not an alleged 'democratic deficit', of

\footnotetext{
${ }^{2}$ Chalmers (2006), p. 316.

${ }^{3}$ Committee of Independent Experts (1999), p. 144.

${ }^{4}$ Ibid. p. 144.

${ }^{5}$ Cf. Follesdal/Hix (2005), pp. 4-5; Fisher (2004), p. 496; Schmitter (2000).

${ }^{6} \mathrm{Cf}$. Follesdal/Hix (2005), p. 19.
} 
the EU: "accountability, rather than an unattainable democratic legitimacy, should be the main concern". ${ }^{7}$

Accountability deficits exist where accountability relationships are lacking or where existing relationships do not function properly, or - to put it more generally - where power escapes accountability. The EU is said to suffer from accountability deficits and it is argued that these deficits contribute to the low public visibility and legitimacy of the EU. ${ }^{8}$ In the words of Verhey and Claes, the accountability deficit in the EU displays itself by non-accountable governance, with the machinery failing at both the European and the national level. 9 Bovens et al. seem less pessimistic about accountability in the EU context and they even refer to occasional whispers of 'accountability overloads'. ${ }^{10}$ Rather than investigating whether the EU in its entirety actually suffers from an accountability deficit, this book examines one specific accountability instrument at the disposal of the European Parliament: parliamentary investigations.

\subsection{The concept of accountability}

\subsubsection{Defining accountability}

In 2001, the European Commission described accountability in its White Paper on European Governance as one of the principles that underpin 'good governance'. ${ }^{11}$ Accountability, the Commission argued, implies that "each of the EU institutions must explain and take responsibility for what it does in Europe". ${ }^{12}$ On an earlier occasion, the Commission defined accountability as an "obligation to answer for a responsibility that has been conferred". ${ }^{13}$ These descriptions are rather vague and therefore of little use in bringing the necessary clarity to the concept of accountability. In this regard, Bovens' definition of accountability is more helpful. He defines accountability as "a relationship between an actor and a forum, in which the actor has an obligation to explain and to justify his or her conduct, the forum can pose questions and pass judgement, and the actor may face consequences". ${ }^{14}$ This corresponds to the definition of Oliver, who states: "accountability has been said to entail being liable to be required to give an account or explanation of actions and, where appropriate, to suffer the consequences, take the blame or undertake to put matters right if it should appear that errors have been made" ${ }^{15}$. According to Strøm, "accountability implies that vis-à-vis agents, principals have a right to

\footnotetext{
${ }^{7}$ Majone (2006), p. 621.

${ }^{8}$ Cf. Harlow (2002), p. 168 and further; Papadopoulos (2007), p. 470; Arnull/Wincott (2002), p. 1.

${ }_{9}$ Verhey/Claes (2008), p. 3.

${ }^{10}$ Bovens/Curtin/'t Hart (2010b), pp. 174-188.

${ }^{11}$ European Commission (2001). European Governance: A White Paper (COM/2001/428, 25.7.2001), p. 10.

12 Ibid. p. 10.

13 European Commission (2000). Reforming the Commission: A White paper, Part I (COM/2000/200, 5.4.2000). p. 34.

${ }_{14}$ Bovens (2007), p. 450.

${ }_{15}$ Oliver (2003), p. 48.
} 
demand information and a capacity to impose sanctions". ${ }^{16}$ These definitions seem to evince a certain degree of consensus on what accountability is essentially about. All of these definitions share what Mulgan describes as the "original or core sense" of accountability: "the process of being called "to account' to some authority for one's actions". ${ }^{17}$

The notions of 'accountability' and 'control' are sometimes used interchangeably. Although both concepts indeed relate to each other, they should not be put on a par. Whereas control can be ex ante, as well as ongoing and ex post, accountability can only be ex post..$^{18}$ Accountability, as Curtin observes, "is concerned with ex post oversight, with ascertaining after the fact, to which extent the agent has lived up to its ex ante mandate". ${ }^{19}$ This book is principally aimed at examining accountability. However, as ex ante, ongoing and ex post oversight cannot always be distinguished clearly in practice, this book touches on several occasions upon other forms of oversight as well.

In the framework of this book, Bovens' definition of accountability is used, as well as his terminology according to which the person or institution held accountable is described as the 'actor' and the account-holder is described as the 'forum'.

\subsubsection{Purposes of accountability}

Some commentators claim that the European Union suffers from an accountability deficit. But why would this be a problem? Why does accountability actually matter?

Three main purposes of accountability can be observed: democratic control, checks and balances and improvement/learning. ${ }^{20}$ In addition to these three direct purposes of accountability, Bovens recognizes two indirect purposes of accountability: legitimacy and catharsis. ${ }^{21}$

\subsubsection{Direct purposes of accountability}

Firstly, accountability is important from a democratic perspective, because it helps citizens to control those holding public office. The democratic perspective is traditionally linked with the principal-agent model. ${ }^{22}$ The logic is as follows. In democratic societies, the people are the ultimate principals. Since 'the people', however, do not as such have the time, and, probably not the ability, to make well-informed decisions, they delegate their power by means of elections to representatives. These representatives, in turn, delegate their power to the executive. The democratic chain of delegation is mirrored by a corresponding chain of accountability that runs in the reverse direction: from the executive to the representatives, and from the representatives to the voters. The voters can

\footnotetext{
${ }_{16} \operatorname{Str} ø \mathrm{~m}(2003)$, p. 62.

17 Mulgan (2000), p. 555.

${ }_{18}$ Curtin (2009), p. 249; Scott (2000), p. 39.

${ }_{19}$ Curtin (2009), p. 250.

20 Cf. Bovens/Curtin/'t Hart (2010a), pp. 49-52; Bovens (2007), pp. 462-467; Aucoin/Heintzman (2000), pp. 45-55.

${ }^{21}$ Bovens (2007), pp. 464-465.

${ }_{22}$ Bovens/Curtin/'t Hart (2010a), pp. 50-51; Bovens/Schillemans/'t Hart (2008), pp. 230231; Bovens (2007), p. 463.
} 
pass their final judgment on the representatives and the executive through democratic elections. This chain of accountability serves to ensure that agents serve the interests of their principals. ${ }^{23}$

The question arises, however, as to how relevant this principal-agent model is for the European Parliament as an accountability forum. In contrast with most of its Member States, the EU lacks a clear chain of delegation from the voters via its representatives in the European Parliament to the executive. It is true that the European Parliament has gained ever more influence on the formation of the European Commission. ${ }^{24}$ However, the European Council still has an important, if not the most important, say in this procedure. ${ }^{25}$ Furthermore, chains of delegation from the voters via the European Parliament to other EU executive actors are thin. Concerning EU agencies, for example, Parliament often has only a marginal role, if any, in the appointment of board members and agency directors. ${ }^{26}$ Members or of the European Central Bank are appointed by the European Council and the European Parliament's role in this procedure is only of a consultative nature. ${ }^{27}$ There is no chain of delegation at all from the voters via the European Parliament to the European Council (except for the President of the Commission therein ${ }^{28}$ and the Council of the European Union $^{29}$, as these chains of delegation run along the lines of national elections. Despite the fact that the principal-agent model is only of little relevance when regarding the European Parliament vis-à-vis executive actors at the EU level, it cannot be said that the European Parliament plays no role in the democratic perspective of accountability. Quite the contrary is true. The mere fact that the European Parliament is the only directly elected body at the European level implies that the democratic perspective does play an important role for the European Parliament as an accountability forum. The European Parliament directly represents EU citizens and it is on behalf of these citizens that it attempts to hold EU executive power to account. This marks an important difference with non-elected (at least not directly elected) accountability forums at the EU level, such as the Court of Justice of the European Union, the Court of Auditors, and the EU Ombudsman.

Secondly, accountability has a constitutional function as it contributes to the prevention of corruption and the extensive use of power by organizing checks and balances. ${ }^{30} \mathrm{~A}$ system of checks and balances does not presuppose a clear distinction between the executive, the legislative and the judicial branch of government. It rather focuses on relationships and interconnections between the bodies exercising executive, legislative and judiciary powers.

\footnotetext{
${ }^{23}$ Strøm (2003), pp. 266-267.

${ }^{24}$ Cf. Priestley (2008), pp. 45-77; Corbett/Jacobs/Shackleton (2007), pp. 267-271.

25 The procedure is laid down in Article 17 (7) of the Treaty on the European Union (TEU).

${ }_{26}$ For a description of Parliament's role in appointments to EU agencies, $c f$. Corbett/Jacobs/Shackleton (2011), pp. 302-307. See also: Dehousse (2008).

${ }_{27}$ Cf. Article 283 (2) TFEU. Although Parliament's role is only consultative, Corbett et al. observe that its opinion is potentially crucial, $c f$. Corbett/Jacobs/Shackleton (2007), pp. 271272.

${ }^{28} \mathrm{Cf}$. Article 15 (2) TEU.

${ }^{29}$ Cf. Article 16 (2) TEU.

so $C f$. Bovens/Curtin/'t Hart (2010a), pp. 51-52; Bovens (2007), p. 463.
} 
The constitutional perspective is of particular importance for the European Parliament as an accountability forum. Instead of a strict separation of powers, the European Union is rather characterized by a balancing of powers. ${ }^{31}$ In this respect, reference is generally made to the constitutional principle of 'institutional balance'. This principle does not imply that the Treaties represent a balanced distribution of the powers, whereby the weight of each institution is the same as that of the others. Rather it refers to the fact that the institutional structure of the $\mathrm{EU}$ is based on the division of powers between the various institutions established by the Treaties. ${ }^{32}$ Accountability should in this respect be seen as an instrument to maintain and organize this balance between the different actors in the EU. The European Parliament attempts to guard the institutional balance by holding EU executive actors to account. The constitutional perspective of accountability is, in the words of Bovens, "essential in order to withstand the ever-present tendency toward power concentration and abuse of powers in the executive power". ${ }^{33}$

Thirdly, accountability provides the executive with feedback from accountability forums on the management of its tasks. This feedback induces executive actors to learn from the past and to improve their performance. ${ }^{34}$ In this way, accountability should be seen as a tool to make and keep the executive effective in delivering its promises and to search for effective and efficient ways of governing.

\subsubsection{Indirect purposes of accountability}

Bovens observes that accountability further serves two indirect purposes, namely legitimacy and catharsis. ${ }^{35}$ In his view, accountability can help to ensure that the legitimacy of governance remains intact or is increased. This is not just the consequence of the three direct purposes which accountability serves. Also in itself, the fact that executive actors publicly give account of their conduct can promote acceptance of government authority and the citizen confidence in the government's administration. ${ }^{36}$ The European Union seems to suffer from legitimacy problems. Legitimacy deficits became apparent in the European Constitution referenda in the Netherlands, France and Ireland and has its origins inter alia in the fact that the decision making process is considered to be distant from citizens. ${ }^{37}$ Legitimacy can be considered in terms of 'input legitimacy' and 'output legitimacy'. In the terms of Lincoln's famous description of the main elements of democracy, input legitimacy refers to government by the people, whereas output legitimacy refers to government for the people. As Curtin observes, input legitimacy - via a compound system of representative democracy or via methods of direct democracy - is out of reach

\footnotetext{
${ }^{31}$ Cf. Curtin (2009), p. 54 and further.

32 Jacqué (2004), p. 383.

${ }^{33}$ Bovens (2007), p. 466.

${ }^{34}$ Bovens/Curtin/'t Hart (2010a), p. 52; Bovens/Schillemans/'t Hart (2008), p. 232. See also:

Aucoin/Heintzman (2000), p. 52; Bovens (2007), pp. 463-464.

${ }^{35} \mathrm{Cf}$. Bovens (2007), p. 464.

${ }^{36}$ Bovens (2007), p. 464.

${ }^{37}$ Cf. Lord (2000), p. 4; Curtin (2009), pp. 283 and further.
} 
for the $\mathrm{EU}$ for the foreseeable future. ${ }^{38}$ Accountability could, however, serve to strengthen the output legitimacy of the EU as it induces decision makers to publicly give account of the decisions they take. Scharpf has most consistently pleaded for an output-oriented rather than an input-oriented legitimization of European Union policies. ${ }^{39}$

Another indirect purpose of accountability is providing public catharsis in the event of catastrophes, tragedies, scandals, and fiascos, such as railway accidents, plane crashes, and bribery scandals. Parliamentary investigations into such events can help to bring a tragic episode to an end by offering a platform for victims to voice their grievances, and for the alleged wrongdoers to account for themselves and to justify or excuse their conduct. ${ }^{40}$

\subsubsection{Three accountability stages}

Three stages can be recognized in the accountability process: the information stage, the debating stage, and the judgement stage. ${ }^{41}$ These stages are a sine qua non for any accountability relationship and the strength of a specific accountability relationship depends to a great extent on the degree to which provision is made for these stages.

The provision of information is an essential prerequisite for an accountability relationship. An accountability forum needs reliable information to be able to gain a thorough picture of the way in which accountability actors have performed their tasks. Therefore, the process of account giving starts with the provision of information. The actor informs the forum about its conduct. One could, for example, think of the President of the European Council informing the European Parliament on the outcome of a European Council summit.

Account giving is more than just an obligation - be it formal or informal - on the part of the actor to report its past performances to a forum. Particularly in the case of failures or incidents it also involves an obligation to explain or justify the performances with regard to these alleged failures or incidents. ${ }^{42}$ Thus provision must be made for a debate to take place between the forum and the actor on the information made available by the latter. Accountability forums may, for example, hear representatives of accountability actors and debate the performances of the latter. Think, for example, of a political debate between the European Parliament and a Commissioner on the implementation of the budget the preceding year.

After the accountability forum has gained a picture of the conduct of an accountability actor, it may deliberate possible 'consequences' for the actor. These consequences need not necessarily be formal, such as a parliamentary vote of no confidence. They can also be informal, such as having to provide an account in front of television cameras, or, as was the case for former

\footnotetext{
${ }^{38}$ Curtin (2009), p. 285.

${ }^{39} \operatorname{Scharpf}(1999)$.

40 Bovens (2007), p. 464.

${ }_{41} C f$. Bovens (2007), p. 451; Verhey and Claes call these stages the stage of 'being accountable', the stage of 'calling to account', and the stage of 'holding to account'. $C f$. Verhey/Claes (2008), p. 12.

${ }^{42}$ Bovens (2007), p. 451.
} 
Commissioner Edith Cresson, having one's public image and career disintegrated as a result of negative publicity. ${ }^{43}$

\subsection{Holding the executive to account by conducting investigations}

This rather general introduction of the concept of accountability serves as an introduction to the subject of this book: the political accountability of EU executive actors (i.e. the accountability actors) to the European Parliament (i.e. the accountability forum) by means of parliamentary investigations (i.e. the accountability instrument).

\subsubsection{Political accountability}

In the context of this book, the concept of accountability denotes political accountability, implying the accountability of executive actors vis-à-vis elected representatives. Bovens points out that accountability vis-à-vis political parties, voters and media may also be regarded as political accountability. This book, however, concentrates solely on the political accountability of EU executive actors vis-à-vis the European Parliament. ${ }^{44}$ Although political accountability can be distinguished from other types of accountability, such as legal accountability (accountability to a court of law), financial accountability (accountability to a court of auditors) and ethical accountability (including rules of good behaviour), they do not necessarily exclude each other. Quite the contrary is true; the European Parliament may very well use legal, financial and ethical arguments to hold the EU executive to political account.

\subsubsection{The EU executive as actor and the European Parliament as forum}

In the EU context, the accountability actors and the accountability forums are not both concentrated within one single institution or body. The European Commission, for example, is not the only executive actor at the European level. It shares EU executive power with several other executive actors, such as the European Council, the Council of the European Union (hereafter also referred to as: 'the Council'), the European Central Bank, EU agencies and Member States. In accountability terms, these EU executive actors are accountability actors. Together they form the EU executive, which can be held to account by accountability forums, one of them being the European Parliament. However, also the European Court of Justice, national parliaments, the Ombudsman and the Court of Auditors are accountability forums in the EU context. This book concentrates on the accountability of EU executive actors vis-à-vis the European Parliament, and so the accountability of EU actors vis-à-vis other accountability forums are not considered here.

Before 1979, when its first direct elections were held, the European Parliament was viewed by many as a 'talking shop'. ${ }^{45}$ Since then, the position of the European Parliament has been significantly strengthened within the

\footnotetext{
${ }^{43}$ Bovens (2007), p. 452.

${ }^{44} C f$. Bovens (2007), p. 455; Bovens/Curtin/'t Hart (2010a), p. 42.

${ }^{45} \mathrm{Cf}$. Rittberger (2005), p. 1.
} 
institutional framework of the European Union. As Nugent points out, the European Parliament is less the "supportive ally" of the Commission against the Council that it was inclined to be and it has become rather a "third side of an institutional triangle". ${ }^{46}$ Although Parliament lacks a right to initiate legislation in any significant field of policy making ${ }^{47}$, it can veto legislation in a large range of policy areas and therefore plays a vital role in the EU legislative process. In the scope of the ordinary legislative procedure (the former codecision procedure), the European Parliament has attained co-equal status with the Council.

Whereas the European Parliament has thus become a strong player in the legislative process, this effect cannot be said to extend to holding the EU executive to account. It is true that the Parliament has developed its powers to scrutinize nominees for inter alia the Commission. In the words of Sir Julian Priestley: "Parliament has established for itself a determinant role in appointing the Commission. A half-hearted consultation of the parliamentary leadership of the 1980 s has developed into the most elaborate advice and consent procedure in the continent's parliamentary experience." ${ }^{48}$ History has also shown that in some cases the European Parliament can be effective in holding the European Commission to account for its actions. The most famous example is the Parliament's contribution to the resignation of the Santer Commission in 1999. The events were heralded at the time as the coming of age of the European Parliament and as the confirmation of the Parliament as "the only Union institution able and willing to hold the Commission to account for its conduct as an administration" ${ }^{49}$ However, Chalmers observes that the Parliament's ability to ensure the Commission's accountablitiy for its work has not developed as far as it ought to have since the events of $1999 .{ }^{50}$ Furthermore, the European Parliament's focus seems to be mainly on the Commission, as the core executive actor of the European Union. ${ }^{51}$ This book aims to discuss the accountability of other EU executive actors vis-à-vis the Parliament as well.

\subsubsection{Parliamentary investigations as an accountability instrument}

The European Parliament has several formal and informal means to hold EU executive actors to account. The Parliament may put questions to executive actors and it may debate specific issues with them. Such debates may be held spontaneously, to discuss questions of the day, or they may be held at regular intervals, for example to discuss annual reports or the annual budget. Commissioners are required to reply to questions from MEPs and a convention has grown whereby the Council also answers questions put to it by MEPs. The

\footnotetext{
${ }^{46}$ Cf. Nugent (2001), p. 189.

${ }_{47}$ However, the Parliament can request the Commission to submit a legislative proposal, $C f$. Article 225 TFEU.

${ }_{48}$ Priestley (2008), p. 76.

${ }^{49}$ Editorial Comment, Common Market Law Review (1999), p. 271. See also on the relations between the Parliament and the Commission after the fall of the Santer Commission: Judge/Earnshaw (2002).

${ }^{50}$ Cf. Chalmers (2006), pp. 334-337.

${ }^{51}$ Hix (2005), p. 32.
} 
presence of individual Commissioners, members of the Council, directors of EU agencies, the President of the ECB and both national and Union civil servants at committee meetings of the European Parliament has become a routine event. ${ }^{52}$

These means of holding the executive to account can be regarded day-to-day accountability mechanisms. Situations may arise in which the Parliament feels that these day-to-day means of holding the executive to account, by asking single questions or debating issues at regular committee meetings, do not do sufficient justice to the complexity and/or the importance of a particular issue. In these cases, Parliament can authorize a standing or a temporary committee to start an in-depth investigation.

This book concentrates on one specific accountability mechanism which the European Parliament can use to hold the EU executive to account: parliamentary investigations. In the context of this book, a parliamentary investigation is defined as: 'a study carried out by a parliamentary committee under the authority of the Parliament. The parliamentary committee gathers information and, once complete, forwards its conclusions to the Parliament, which can take action on that basis'.

Parliament can investigate specific issues both with the aim of holding executive actors to account and with the aim of preparing decisions which are not connected to accountability, for example in the context of the Parliament's legislative function. Both types of investigation are discussed hereafter.

\subsubsection{Accountability investigations}

Firstly, the Parliament can investigate specific issues with a view to scrutinizing executive action and holding executive actors to account. The Parliament can start such investigations for example when it suspects an EU executive actor, e.g. the Commission, of maladministration. In such cases, the Parliament will generally ask questions first and/or debate the alleged mismanagement with the Commission. However, if the Parliament feels that it needs more information in order to assess the situation adequately, it may start a parliamentary investigation. In the course of such an investigation, the Parliament can obtain information by hearing witnesses, by requesting written information, and by conducting fact-finding visits.

\subsubsection{Non-accountability investigations}

Secondly, Parliament may want to investigate specific issues without the aim of holding executive actors to account. This occurs regularly in the context of the Parliament's legislative function. Take, for example, a case where the Commission submits a legislative proposal to which the Parliament needs to adopt a position. It is, of course, perfectly possible that Parliament is already well-informed about the specific subject matter of the legislative proposal and that the Parliament can follow its usual internal procedure to adopt a parliamentary position. However, it is also possible that the Parliament needs to become better acquainted with the subject matter before adopting a position. In such cases, an investigation may be started on this issue, during the course

${ }^{52}$ Cf. Corbett/Jacobs/Shackleton (2007), pp. 283-284. 
of which the Parliament can invite experts to provide MEPs with detailed and independent information, or the Parliament can invite the Commission to elaborate further on the legislative proposal.

The Parliament may also require more information on a specific issue if concrete legislative proposal are not (yet) available. This might be the case for rather general matters of public concern about which the Parliament feels it needs more information. In the past, the European Parliament has established temporary committees to investigate such matters, notably the rise of fascism and racism, the drugs problem, employment, human genetics, and climate change. As a rule, such investigations ultimately lead to recommendations for legislative proposals.

\subsubsection{Object of research: accountability investigations}

'Accountability investigations' thus do, and 'non-accountability investigations' do not serve as an instrument to hold EU executive actors to account. In view of this book's focus on accountability in the European Union, the spotlight is therefore put on accountability investigations, leaving non-accountability investigations aside. Hence, where this book uses the terms 'investigations' or 'parliamentary investigations', reference is being made to 'accountability investigations'.

Admittedly, in practice it is not always possible to cut a clear line between the two categories, as parliamentary investigations generally have features of both types of investigation. Nonetheless, it does make sense to distinguish between them. In the first place because investigations which do not serve as a mechanism of accountability (clear non-accountability investigations) are not relevant in the context of this book. Moreover, non-accountability investigations are by definition inadmissible within the framework of the right of inquiry ex Article 226 TFEU, as committees of inquiry can only be set up to scrutinize executive actors for 'alleged contraventions or maladministration in the implementation of Union law', which necessarily implies the examination of past executive action.

The right of inquiry is specifically designed for conducting accountability investigations. This book therefore focusses primarily on the right of inquiry. Other parliamentary committees, such as temporary committees (the 'special committees') and standing committees, do however conduct accountability investigations. The investigative work of these committees is therefore also discussed. By doing so, a complete picture of the accountability investigations conducted by the European Parliament is presented.

\subsection{Research questions and methodology}

Writing a doctoral thesis not only implies clearly defining what will be examined, but also what will not be examined. Of course it would be interesting to examine in detail the overall position of the European Parliament within the constitutional framework of the European Union by focusing not only on its investigative function, but also on its other functions, such as its legislative and representative functions. And it would also be interesting to go beyond examining investigations conducted by the European Parliament and 
to look at the wider context by comparing the investigative function of the European Parliament with the investigative function of a representative selection of national parliaments. However, in view of practical constraints both the object of the study and the way it is analyzed are necessarily limited.

The main research question of this book is how the European Parliament uses its investigative powers to hold executive action in the European Union to account. In order to answer this question, this book examines the three types of committees which conduct parliamentary investigations: the temporary committees of inquiry (Chapter 2), the temporary special committees (Chapter 3 ), and the standing committees (Chapter 4). These chapters examine the legal position of these committees, i.e. their formal powers of investigation, with regard to inter alia the invitation of witnesses and access to documents. Furthermore, the committees' working methods are analysed on the basis of case studies of investigations conducted by them. An examination is made of how and the extent to which they can contribute, and actually do contribute, to holding EU executive actors to account. Conclusions are drawn in Chapter 5. The research on the legal provisions concerning parliamentary investigations follows a traditional legal approach, implying that relevant legal provisions and legal literature is studied. Although a purely theoretical legal study might perhaps be interesting from a legal perspective, its practical relevance would be limited. Particularly in the field of constitutional law, relationships are not only governed by normative legal provisions but also (if not mainly) by the actual political setting. Therefore, previous investigations by the European Parliament are examined on the basis of parliamentary reports and academic literature on the investigative work of the parliamentary committees. Furthermore, interviews held with practitioners in the field are also used. These interviews provide insight into parliamentary investigations and also allow provisional impressions to be tested. 


\section{INVESTIGATIONS BY TEMPORARY COMMITTEES OF INQUIRY}

\subsection{Introduction}

Since its first direct elections in 1979, the European Parliament has set up several temporary committees of inquiry. Before 1993, these committees were set up on the basis of the internal Rules of Procedure of the European Parliament. With the entry into force of the Maastricht Treaty on 1 November 1993, the right of inquiry of the European Parliament was for the first time recognized as primary law. The right of inquiry is currently laid down in Article 226 TFEU. Detailed provisions governing the exercise of the right of inquiry can be found in an interinstitutional agreement between the European Parliament, the Council and the European Commission. ${ }^{53}$

The right of inquiry aims to assist the European Parliament in performing its scrutiny and control function. In contrast to the 'day-to-day' methods for the Parliament to scrutinize executive action by means of posing (oral and written) questions and by holding debates, the right of inquiry represents a rather heavy weapon in the armoury of the Parliament. The right of inquiry, which can only be asserted by a parliamentary majority, enables the Parliament to investigate in detail specific matters of public concern. For reasons of efficiency, the plenum mandates a small committee, consisting of MEPs and reflecting the composition of the Parliament, to conduct the inquiry. The direct goal of inquiries is to assess who was politically accountable for what. However, other goals are generally served at the same time. If a committee of inquiry identifies an abuse, it will generally go beyond merely assessing political accountability as it is likely that the committee will make recommendations to prevent similar abuses in the future.

Having relevant, reliable and complete information is of vital importance in order to determine precisely who was accountable for specific events. Therefore committees of inquiry need to have ways of gathering information, for example by hearing witnesses and having access to documents. It may be assumed that the strength of the right of inquiry depends to a certain extent on the powers a committee of inquiry has to gather information. Committees equipped with strong investigative powers may be expected to be more effective in scrutinizing executive action than committees with limited powers.

When it comes to the European Parliament, it has been assumed that the powers of its committees of inquiry are fairly weak. ${ }^{54}$ Moreover, it seems as if the European Parliament itself does not consider its right of inquiry an effective mechanism to hold EU executive actors to account. The initial enthusiasm on the part of the Parliament to establish committees of inquiry seems to have waned in recent years. Two committees of inquiry were

\footnotetext{
${ }^{53} \mathrm{Cf}$. Decision of the European Parliament, the Council and the Commission of 6 March 1995 on the detailed provisions governing the exercise of the European Parliament's right of inquiry (OJ L 1 13, 19.5.1995, pp. 2-4).

${ }^{54} C f$. Shackleton (1998), p. 117 and further; (2007). European Parliament (2007). Report on the crisis of the Equitable Life Assurance Society. Final Report (A6-0203/2007, 23.5.2007), p. 357.
} 
established shortly after the right of inquiry was formally recognized in the Maastricht Treaty, ${ }^{55}$ but only one committee has been established since then. ${ }^{56}$ At the same time, however, the Parliament has made substantial use of its ability to establish other - formally weaker - temporary committees on the basis of its own Rules of Procedure ${ }^{57}$, which appears to confirm that the teeth of committees of inquiry are indeed dull.

The course of events before the downfall of the Santer Commission in 1999 is remarkable. The right of inquiry was considered not to be the most suitable instrument to investigate the allegations of fraud, mismanagement and nepotism in the European Commission. ${ }^{58}$ Consequently, the European Parliament did not establish a parliamentary committee of inquiry, but delegated its supervisory power to an extra-parliamentary Committee of Independent Experts which was not constituted under any precise institutional regulation and which had no formal investigative power. ${ }^{59}$ This gives cause for thought. Despite the existence of an instrument specifically designed to investigate allegations of maladministration, the European Parliament preferred to delegate the investigation to external experts. Lequesne and Rivaud concluded in clear terms: "the creation of the Committees of Independent Experts is the direct result of the EP's inability to bring into play the formal mechanisms of parliamentary control - the right of censure and the Temporary Committees of Inquiry"60. Similarly, the committee of inquiry created to investigate the crisis of the Equitable Life Assurance Society described the powers of committees of inquiry in 2007 as: "very limited and not in line with the political stature, needs and competences of the European Parliament". ${ }^{61}$

It has thus been assumed that the current right of inquiry is a rather weak instrument that is unsuitable for holding EU executive actors to account. This chapter scrutinizes the tenability of this assumption. Section 2.2 discusses the right of inquiry between 1979, when the European Parliament was directly elected for the first time, and 1993, when the right of inquiry was formalized in the EC Treaty. Section 2.3 focuses on the current constitutional framework for

55 The Interinstitutional Agreement entered into force on 19 May 1995. In December 1995, the Parliament decided at its plenary session to set up a temporary committee of inquiry into the Community Transit System ( $c f$. Section 2.5.1). In July 1996, the Parliament decided to set up a temporary committee of inquiry into BSE (cf. Section 2.5.2).

${ }_{56}$ About ten years after the establishment of the committees of inquiry into Transit and BSE, the Parliament decided at its plenary session of January 2006 to set up a committee of inquiry into the crisis of the Equitable Life Assurance Society ( $c f$. Section 2.5.3).

${ }_{57}$ Chapter 3 addresses these other temporary committees of the European Parliament, the so-called 'special committees'.

${ }^{58}$ Cf. Lequesne/Rivaud (2003), p. 701.

${ }^{59} \mathrm{Cf}$. Committee of Independent Experts (1999), p. 10. For a detailed analysis of the reports of the Committee of Independent Experts, $c f$. Craig (2000).

${ }^{60}$ Lequesne/Rivaud (2003), p. 707; Van Gerven, who regretted that no committee of inquiry was established, suggested that the procedure of Article 193 EC Treaty (at present: Article 226 TFEU) was not followed because of a 'political deadlock' at the time between the two major political groups, $c f$. Van Gerven (2009), p. 120.

${ }^{61}$ European Parliament (2007). Report on the crisis of the Equitable Life Assurance Society. Final Report (A6-0203/2007, 23.5.2007), p. 357. 
the right of inquiry. Subsequently, Section 2.4 analyzes the proceedings and powers of committees of inquiry. The practical experience of the three committees of inquiry established since 1993 are discussed in Section 2.5. Section 2.6 discusses the future of the right of inquiry and proposals made in this respect. Section 2.7 draws conclusions about the right of inquiry.

\subsection{The right of inquiry prior to Maastricht}

Two periods can be distinguished when analyzing the right of inquiry from the first direct election to the European Parliament in 1979 to the present day, namely the period before and the period after the formal recognition of the right of inquiry as laid down in the EC Treaty in 1993.

Ever since its foundation, the European Parliament has proved creative in securing rights informally prior to these rights being recognized in a formal sense. The development of the right of inquiry is no exception to this general rule. Before 1993, the right of inquiry was not recognized as primary law. However, in 1979 the Parliament had already established a temporary committee to investigate a specific issue, namely the situation of women in Europe. ${ }^{62}$ The Parliament adopted its first Rules of Procedure in 1981. These Rules of Procedure provided for two types of temporary committee; on the basis of Rule 91 the Parliament could establish ordinary temporary committees and on the basis of Rule 95 it could establish temporary committees of inquiry. The functions of these two types of temporary committees correspond with the two types of investigations as described in Section 1.4.3: committees of inquiry were designed to conduct 'accountability investigations' and ordinary temporary committees were designed to conduct 'non-accountability investigations'. The committees of inquiry are discussed hereafter whereas the ordinary temporary committees (which are now called 'temporary special committees') are adressed in Chapter 3.

Rule 95 of the 1981 EP Rules of Procedure regarding the right of inquiry stipulated:

'1. Parliament shall, on a motion by one quarter of its Members and without previously referring the motion to committee, set up a committee of inquiry to investigate specific matters. The motion shall indicate the matter to be investigated, which must fall within the sphere of activities of the Communities.

On a motion by one quarter of its Members, Parliament shall automatically set up a committee of inquiry; such a motion need not be put to the vote in the House.

(...).

2. Parliament shall determine the composition of the committee of inquiry on a proposal from the Bureau, subject to the provisions of Rule $92(1)$, second sentence.

\footnotetext{
62 The investigation of this committee led to the creation of a permanent committee on women's affairs (which still exists under the name 'Women's Rights and Gender Equality'). Cf. Corbett/Jacobs/Shackleton (2011), p. 332.
} 
3. The provisions of these Rules of Procedure relating to the committees shall apply to the proceedings of the committee of inquiry and to the powers of its chairman.'

In the Rules of Procedure 1987, this provision was replaced by Rule $109(3)^{63}$, which stipulated:

'Parliament shall, at the request of one quarter of its current Members, set up committees of inquiry to investigate alleged contraventions of Community law or incidents of maladministration with respect to Community responsibilities. The request shall indicate the matter to be investigated and contain a justification in sufficient detail for the President, without reference to Parliament, to decide whether the conditions are met.'

Prior to 1993, the right of inquiry was thus designed as a right which could be asserted by a parliamentary minority ('Parliament shall, on a motion by one quarter of its Members and without previously referring the motion to committee, set up a committee of inquiry to investigate specific matters' (my italics, $C N S$ )). This corresponds to the current right of inquiry of the German Bundestag, which is also designed as a minority right. ${ }^{64}$ The rationale for having this minority right was, in the words of the draftsman of the European Parliament's committee on the Rules of Procedure and Petitions, "that a majority should not have the possibility to prevent investigations of unpleasant or embarrassing events". ${ }^{65}$ A qualified minority could not, however, use the right of inquiry to investigate any matter it wanted. The scope of the right of inquiry was restricted to 'specific matters' which had to fall 'within the sphere of activities of the Communities' ( $c f$. the wording of Rule 95 of the $1981 \mathrm{EP}$ Rules of Procedure). In this regard, the draftsman of the committee on the Rules of Procedure and Petitions observed: "The competences of a committee of inquiry shall be limited to investigating specific matters for which a standing committee is not equipped, e.g. because of its size or workload, or for which no existing standing committee is competent because the investigation of a specific matter is not covered by the competences of the existing committees as decided by Parliament". ${ }^{66}$ The expression 'specific matters' was intended to be restrictive. It did not mean that committees of inquiry could be set up to consider specific policy matters or changes in existing law. The phrase 'specific matters' rather denoted matters such as specific allegations of corruption or

\footnotetext{
${ }^{63}$ It should be noted that the right of inquiry was briefly governed by Rule 91 (3) Rules of Procedure 1986 between 1986 and 1987. The wording of Rule 91 (3) Rules of Procedure 1986 is identical to the wording of Rule 109 (3) Rules of Procedure 1987.

${ }^{64}$ Article 44 (1) of the German Basic Law stipulates: "The Bundestag shall have the right, and on the motion of one quarter of its Members the duty, to establish an investigative committee, which shall take the requisite evidence at public hearings. The public may be excluded."

${ }_{65}$ European Parliament (1982). Working document on the interpretation of Rule 95 of the Rules of Procedure (PE 80.257, 3.9.1982), p. 5.

${ }_{66}$ Ibid. p. 6.
} 
maladministration and contraventions of existing law. ${ }^{67}$ However, Sir Christopher Prout (EPP) observed in 1986 that the Parliament had given a rather broad interpretation of 'specific matters'.68 This phrase was therefore defined more specifically when the Parliament changed its Rules of Procedure in 1987. Rule 109 (2) of 1987 replaced 'specific matters' with 'alleged contraventions of Community law or incidents of maladministration with respect to Community responsibilities'.

The Parliament set up eight temporary committees of inquiry between 1979 and 1993:

\begin{tabular}{|l|l|}
\hline Year & Investigation \\
\hline $1983-$ & $\begin{array}{l}\text { The treatment of toxic and dangerous substances. The committee } \\
\text { examined the procedures applicable to handling toxic and dangerous } \\
\text { substances, particularly concerning the trans-frontier shipment of } \\
\text { dangerous waste in the light of a related accident (the 'Seveso } \\
\text { accident'). The committee's final report stimulated new legislation in } \\
\text { this field. }\end{array}$ \\
\hline 1984 & $\begin{array}{l}\text { The rise of fascism and racism. The committee was set up shortly } \\
\text { after the 1984 EP elections and the formation of a 'European Right' } \\
\text { group led by the French nationalist Jean-Marie Le Pen. The } \\
\text { committee's work led to the adoption by the Council, Commission, } \\
\text { Parliament and Member States of the 'Joint Declaration against racism } \\
\text { and xenophobia' in 1986. }\end{array}$ \\
\hline $1985-$ & $\begin{array}{l}\text { The drugs problem. The committee compared the methods used by } \\
\text { Member States to deal with the drugs problem and it examined the } \\
\text { problem of extraditing drug traffickers. It further examined the } \\
\text { problems facing developing countries where drugs are produced. The } \\
\text { investigation stimulated the interest of Member States to cooperate in } \\
\text { this field, which was eventually given a legal basis in the Maastricht } \\
\text { Treaty. }\end{array}$ \\
\hline 1988 & $\begin{array}{l}\text { Agricultural stocks. The committee investigated the causes and } \\
\text { ramifications of agricultural stocks at a time when the debate on the } \\
\text { reform of the Common Agricultural Policy (CAP) was at a crucial } \\
\text { juncture. The committee's conclusions contributed to the shaping of } \\
\text { the reformed CAP. } \\
\text { investigate a transnuclear scandal in Mol (B). It concluded that } \\
\text { were lacunae in Community regulations pertaining to the transfrontier } \\
\text { shipment of nuclear waste. The committee initially had some } \\
\text { difficulties in obtaining testimony from some Belgian government } \\
\text { officials. As a result, the problems faced by inquiry committees were }\end{array}$ \\
\hline $1986-$
\end{tabular}

${ }_{67}$ European Parliament (1986). Working document incorporating proposed amendments to the Rules of Procedure concerning committees of inquiry (A2-100/86, 15.8.1986), p. 11.

${ }^{68}$ Ibid. p. 11. 


\begin{tabular}{|l|l|}
\hline 1 & $\begin{array}{l}\text { discussed by the Council. The Council adopted a statement } \\
\text { emphasising that while there was no legal obligation on national } \\
\text { authorities to attend Parliament's hearings, they were invited } \\
\text { nonetheless to do so on a voluntary basis, bearing in mind the duty of } \\
\text { sincere cooperation. The Council accepted that invitations from the } \\
\text { Parliament to national authorities could be sent through the Council. }\end{array}$ \\
\hline $1988-$ & $\begin{array}{l}\text { Hormones in meat. The committee investigated this aspect of } \\
\text { Community policy which had sparked off a trade war with the USA. } \\
\text { The committee endorsed the continuation of the Community's } \\
\text { restrictive policy in this matter. }\end{array}$ \\
\hline $1989-$ & $\begin{array}{l}\text { The application of the Joint Declaration against racism and } \\
\text { xenophobia. The committee was a follow-up to the 1984 committee } \\
\text { on the same subject. Its aim was to investigate what progress had been } \\
\text { made in the five years since the initial investigation. }\end{array}$ \\
\hline 1991 & $\begin{array}{l}\text { Trans-frontier crime linked to drug trafficking. The committee } \\
\text { compared the divergent legal situations and general approaches of } \\
\text { governments to trans-frontier criminality and drug trafficking and } \\
\text { made proposals in the build-up to the Maastricht Treaty. }\end{array}$ \\
\hline
\end{tabular}

Figure 2.1 Inquiries between 1979 and $1993^{69}$

It is striking that only the inquiry into the handling of nuclear materials appears to have been specifically aimed at 'alleged contraventions of Community law or incidents of maladministration with respect to Community responsibilities'. Thus it can be observed that despite the stricter definition of the right of inquiry being introduced in 1987, the European Parliament continued to interpret the scope of its right of inquiry rather broadly.

\subsection{The right of inquiry since Maastricht; legal framework}

With the entry into force of the Maastricht Treaty in 1993, the right of inquiry of the European Parliament was given formal status in the EC Treaty. In comparison with the pre-Maastricht arrangement, a restriction was added to the Treaty provision; committees of inquiry could no longer be established in case of simultaneous judicial investigations into the same facts. This is the sub judice rule, which is discussed in more detail in Section 2.4.3.1. The scope of the right of inquiry, however, remained restricted to 'alleged contraventions or maladministration in the implementation of Community law'.

The right of inquiry is currently established as primary law in Article 226 TFEU. Detailed rules on the right of inquiry have been laid down in an interinstitutional agreement between the European Parliament, the Council and the Commission, and in the Rules of Procedure of the European Parliament. These arrangements are discussed separately below.

\subsubsection{Article 226 TFEU}

Article 226 TFEU stipulates:

${ }^{69} C f$. Corbett/Jacobs/Shackleton (2011), pp. 331-333, and Costa (2001), p. 215-216. 
'In the course of its duties, the European Parliament may, at the request of a quarter of its component Members, set up a temporary Committee of Inquiry to investigate, without prejudice to the powers conferred by the Treaties on other institutions or bodies, alleged contraventions or maladministration in the implementation of Union law, except where the alleged facts are being examined before a court and while the case is still subject to legal proceedings.

The temporary Committee of Inquiry shall cease to exist on the submission of its report.

The detailed provisions governing the exercise of the right of inquiry shall be determined by the European Parliament, acting by means of regulations on its own initiative in accordance with a special legislative procedure, after obtaining the consent of the Council and the Commission.'

With the entry into force of the Lisbon Treaty, this provision succeeded Article 193 EC Treaty. The previous Article 193 EC was amended on three points.

Firstly, the word 'component' was added to the first sentence. This linguistic amendment has brought no changes in a legal sense. The other two amendments, however, have brought about legal changes. The scope of the right of inquiry has been extended from matters of 'Community law' (the former first pillar) to matters of 'Union law'. Section 2.4.3.1 addresses this amendment. Furthermore, the last sentence of Article 193 EC Treaty ('The detailed provisions governing the exercise of the right of inquiry shall be determined by common accord of the European Parliament, the Council and the Commission') was replaced by the last sentence of Article 226 TFEU (see above), which includes a special legislative procedure on the basis of which the detailed provisions governing the exercise of the right of inquiry shall be determined. Section 2.3.2 discusses this amendment.

\subsubsection{Interinstitutional Agreement}

The former Treaty provisions on the right of inquiry (Article 138c and 193 EC Treaty) included an instruction to the European Parliament, the Council and the Commission to determine by common accord detailed provisions governing the exercise of the right of inquiry. In 1995, fifteen months after the entry into force of the new legal basis, these institutions concluded such an interinstitutional agreement. ${ }^{70}$ It appeared to be difficult to overcome the enormous differences of opinion between the three institutions. ${ }^{71}$ The European Parliament proposed far-reaching powers for the new committees of inquiry, such as a general right of summons, a right of access to documents, a right to swear in witnesses, and mechanisms to penalize persons and

\footnotetext{
70 Decision of the European Parliament, the Council and the Commission of 6 March 1995 on the detailed provisions governing the exercise of the European Parliament's right of inquiry (OJ L 1 13, 19.5.1995, pp. 2-4).

${ }^{71}$ Shackleton (1998), p. 119; Wiersma (2004), p. 227.
} 
authorities in the event of a refusal to cooperate in the course of an inquiry. ${ }^{72}$ The Parliament's proposal differed enormously from that of the Council, which did not include strong inquiry powers. ${ }^{73}$ The Council, rather, advocated an arrangement where European and national authorities were no more than voluntary co-operators in the course of parliamentary inquiries. The Parliament and Council were thus diametrically opposed to each other as to the 'teeth' the new committees of inquiry should have. ${ }^{74}$

Although the draft result of the negotiations shows that the Council came off best, the Parliament's standing committee on Institutional Affairs nevertheless advised the plenum to accept the proposed compromise, stating: "The European Parliament may not be entirely satisfied with the compromise reached. However, the result seems acceptable and necessary as a means of acquiring experience of parliamentary committees of inquiry over the next few years. Rejection of the compromise would prevent the creation of this important means of parliamentary scrutiny for an indefinite period. Instead, the compromise will make it possible to examine in public any shortcomings in the present rules on the basis of practical examples and thereby to create the necessary political pressure to bring about a revision of the provisions." ${ }^{5}$ The plenary subsequently approved the text of the compromise.

The Interinstitutional Agreement (hereafter also referred to as 'IIA') contains provisions concerning inter alia the invitation of witnesses, the legal position of witnesses, and access to documents. Section 2.4 discusses these provisions in more detail. Article 6 IIA specifies that 'at the request of the European Parliament, the Council or the Commission, the above rules may be revised as from the end of the current term of the European Parliament in the light of experience'. However, seventeen years and three inquiries later, no such revision has been concluded. Due to the entry into force of the Lisbon Treaty, the Interinstitutional Agreement is - at least with regard to the terminology used therein - outdated and in need of revision. Even though the pillar system does not exist anymore as such, the 1995 IIA still refers to the 'European Communities', to 'Community law', to 'Community legislation' et cetera. The question of whether the agreement is in need of further change, namely with regard to the legal position of committees of inquiry, is discussed throughout this chapter.

At the national level, the rules concerning the right of inquiry are generally laid down in an inquiry act which has been adopted according to a general legislative procedure. ${ }^{76}$ Whereas such a national legislative process may be assumed to be transparent, the IIA is a product of negotiations held between

\footnotetext{
72 European Parliament (1992). Proposal of the European Parliament on parliamentary committees of inquiry (A3-0302/02, OJ C 21, 25.1.92, pp. 147-151).

${ }^{73} \mathrm{Cf}$. Council of Ministers (1994). Proposal of the Council on parliamentary committees of inquiry (SN 1338/94, 3.2.1994).

${ }^{74}$ Shackleton (1998), p. 117.

${ }^{75}$ European Parliament (1995). Committee on Institutional Affairs. Report on the right of inquiry of the European Parliament (A4-0003/95, 12.1.1995), p. 14.

${ }^{76}$ European Parliament (2007). AFCO committee. Parliamentary committees of inquiry: a survey (31.1.2007), pp. 13-14.
} 
the European Parliament, the Commission and the Council behind closed doors. Furthermore, one must almost fully rely on a literal interpretation of the Interinstitutional Agreement, as there is no explanatory memorandum or travaux préparatoires explaining the single provisions of the agreement.

Whereas prior to Lisbon the IIA was amended by common accord of the three main institutions, the Parliament now has an exclusive right to initiate provisions regarding its right of inquiry. Since the approval of the Council and the Commission is still required for such provisions to take effect, one could easily play down the advantage of this novelty and argue that it does not effectively change the former situation. However, it can also be argued that the amendment may encourage the Parliament to initiate revised rules, and that it may also put the Commission and the Council under additional pressure to publicly take a standpoint on the powers of committees of inquiry. The standing committee on Constitutional Affairs, not surprisingly, took the view that the special legislative procedure would "reinforce" the Parliament's position in the interinstitutional negotiations. ${ }^{77}$

In addition to this rather political consideration, the amended wording has further legal consequences. Whereas under the former Article 193 EC Treaty the three institutions were entrusted to negotiate an interinstitutional agreement, Article 226 TFEU entrusts the European Parliament to address to the Council and the Commission a proposal to conclude a regulation. Whereas interinstitutional agreements are applicable inter partes ${ }^{78}$, regulations are applicable erga omnes. ${ }^{79}$ As a consequence, such an arrangement could include legal powers vis-à-vis authorities and persons other than the Member State governments, the Council and the Commission (and the persons working for them).

With the entry into force of the Lisbon Treaty, the Parliament appointed British Labour MEP David Martin to prepare a parliamentary proposal for such a regulation on the right of inquiry. Section 2.6.2 discusses the proposed modifications to the right of inquiry.

\subsubsection{Rules of Procedure of the European Parliament}

In accordance with Article 2 (1) IIA, the Parliament has laid down 'the composition and rules of procedure of temporary committees of inquiry' in its Rules of Procedure. Rule 185 consists of organizational stipulations regarding, for example, the requirements for a request to set up a committee of inquiry and the allocation of duties among the members of inquiry committees. Section 2.4 discusses the provisions of Rule 185 Rules of Procedure in more detail.

\footnotetext{
77 European Parliament (2009). Conference of Committee Chairs. Letter of 11 February 2009 from Gerardo Galeote forwarding his report on the action taken in the parliamentary committees concerned on the basis of the recommendations of the Committee of Inquiry into the Equitable Life Assurance Society (PE 421.757/CPG), p. 6.

78 Cf. De Witte (2008), p. 102.

79 Article 288 TFEU stipulates: "A regulation shall have general application. It shall be binding in its entirety and directly applicable in all Member States".
} 


\subsubsection{Legal status of the arrangements}

The question arises as to how the three arrangements (Article 226 TFEU, the Interinstitutional Agreement, and Rule $185 \mathrm{EP}$ Rules of Procedure) should be qualified in legal terms and how they relate to each other.

Article 226 TFEU is a source of primary law and as such is legally binding. Assessing the legal status of the Interinstitutional Agreement on the right of inquiry of the European Parliament appears to be more problematic. The EC Treaty was silent on the legal status of interinstitutional agreements. Under Lisbon, however, Article 295 TFEU stipulates that the Parliament, the Council, and the Commission may conclude interinstitutional agreements 'which may be of a binding nature'. In March 1996 the Court of Justice ruled that interinstitutional agreements may be of a binding nature. It considered with regard to an interinstitutional agreement between the Council and the Commission: "It is clear, moreover, from the terms of the Arrangement, that the two institutions intended to enter into a binding commitment towards each other". ${ }^{80}$ It is by all means not possible to state in general terms that interinstitutional agreements, typified by Westlake as "a sort of constitutional glue" 81 , are legally binding. ${ }^{82}$ The Lisbon Treaty has brought no changes in this respect and it therefore remains necessary to scrutinize each specific agreement in order to draw conclusions about its legal status. Furthermore, if interinstitutional agreements are indeed of a binding nature, they are applicable inter partes, i.e. not erga omnes. ${ }^{83}$

It must be concluded that the Interinstitutional Agreement containing the detailed provisions governing the exercise of the right of inquiry is legally binding. ${ }^{84}$ Firstly, the agreement is directly derived from a Treaty provision. As Monar points out, all interinstitutional agreements concluded by virtue of a Treaty provision must be regarded as legal acts derived from the Treaties and therefore as legally binding. ${ }^{85}$ Secondly, the use of words such as 'shall' and 'may not' points to a clear determination of legal competences and to an intention of the institutions to enter into a binding commitment. This intention is further demonstrated by the preamble of the agreement, which contains the phrase: 'Whereas temporary committees of inquiry must have the means necessary to perform their duties; whereas, to that end, it is essential that the Member States and the institutions and bodies of the European Communities take all steps to facilitate the performance of those duties'. In conjunction with the duty of sincere cooperation laid down in Article 4 (3) EU Treaty, the wording of the preamble leads to the conclusion that this Interinstitutional Agreement is binding upon the concluding parties. ${ }^{86}$

\footnotetext{
${ }^{80}$ Cf. Case C-25/94 Commission v Council, para. 49.

${ }^{81}$ Westlake (1994), p. 101. Driessen refers to interinstitutional agreements as the "cartilage enabling the legal bones to move. Without it a certain constitutional arthritis is bound to occur", $c f$. Driessen (2007), p. 266.

${ }^{82}$ Hummer (2007), p. 47-48.

${ }^{83}$ See also: De Witte (2008), p. 102.

${ }^{84}$ According to Driessen, the Interinstitutional Agreement on the right of inquiry of the European Parliament "clearly is a legally binding instrument". Cf. Driessen (2007), p. 13.

${ }^{85}$ Cf. Monar (1994), p. 697.

${ }^{86} \mathrm{Cf}$. Senden (2005), p. 21-22.
} 
The last arrangement on the right of inquiry is Rule 185 of the Rules of Procedure of the European Parliament. Article 232 TFEU stipulates that the European Parliament shall adopt its own Rules of Procedure. The rules created on the basis of this Treaty provision are internal organizational rules of the Parliament which are formulated by the Parliament itself and which cannot be legally binding upon third parties.

\subsubsection{Duty of sincere cooperation}

In addition to the specific legal arrangements which determine the legal position of committees of inquiry in relation to $\mathrm{EU}$ and national executive actors, another - rather general - legal figure needs to be addressed at this stage: the duty of sincere cooperation.

The duty of sincere (or loyal) cooperation has its basis in Article 4 (3) EU Treaty, which reads:

'Pursuant to the principle of sincere cooperation, the Union and the Member States shall, in full mutual respect, assist each other in carrying out tasks which flow from the Treaties.

The Member States shall take any appropriate measure, general or particular, to ensure fulfilment of the obligations arising out of the Treaties or resulting from the acts of the institutions of the Union.

The Member States shall facilitate the achievement of the Union's tasks and refrain from any measure which could jeopardize the attainment of the Union's objectives.'

Article 4 (3) EU Treaty contains two positive obligations ('The Member States shall take any appropriate measure, general or particular, to ensure fulfilment of the obligations arising out of the Treaties or resulting from the acts of the institutions of the Union', and 'The Member States shall facilitate the achievement of the Union's tasks') and one negative obligation ('The Member States shall $[\ldots]$ refrain from any measure which could jeopardize the attainment of the Union's objectives').

Following CJEU case law, the duty of sincere cooperation must be interpreted more broadly than the wording of Article 4 (3) EU Treaty suggests. ${ }^{87}$ The principle entails a mutual duty of sincere cooperation between the Member States and the EU institutions ${ }^{88}$, between Member States inter se, and between EU institutions inter se. ${ }^{89}$ According to De Witte, the duty of sincere cooperation serves "to allow for the flexible regulation of the multiple conflicts that may arise in a multi-level political system like that of the European Union where these conflicts cannot be solved by 'simply' enforcing the division of competences between those levels". ${ }^{90}$ In this sense, the duty of loyal

${ }^{87}$ Cf. Senden (2003), p. 71; De Witte (1995), p. 142; Majone (2005), p. 80.

${ }_{88}$ Cf. Case-44/48 Hurd, para. 38; Case C-2/88 Zwartveld.

${ }^{89}$ Cf. Case C-65/93 European Parliament v Council.

${ }^{90}$ De Witte (1995), p. 142. 
cooperation can serve as a guideline for settling conflicts between committees of inquiry on the one hand, and EU institutions and Member States on the other.

Majone observes that the function of the duty of loyal cooperation is to fill gaps which may arise in EU law. ${ }^{91}$ The question arises whether this principle can go beyond this and be an independent source of rights and obligations for cases in which there is no provision in primary or secondary EU law and where further clarification is needed. In his opinion in Case C-303/90 (France v. Commission), Advocate-General Tesauro formulated a negative answer, stating that the duty of sincere cooperation cannot be invoked "in the absence of a particular provision in the Treaty or in binding acts adopted by the institutions". ${ }^{92} \mathrm{He}$ thus argues that the duty of sincere cooperation cannot in itself call into existence rights and obligations. This view may be supported, as a broader interpretation of the principle of sincere cooperation would endanger the principle of legality.

The above implies that the duty of sincere cooperation serves as general guidance for the interpretation of the legal provisions concerning the right of inquiry. Moreover, the duty of sincere cooperation prescribes that EU authorities and EU Member States are under a general duty to cooperate in the course of parliamentary inquiries. EU authorities or Member States which persistently and deliberately thwart the work of committees of inquiry clearly act in breach of the duty of sincere cooperation. However, the duty of sincere cooperation cannot in itself call into existence additional inquiry powers. It does not obtain significance on its own, but only in conjunction with other provisions of EU law.

\subsection{Proceedings and powers of committees of inquiry}

Whereas the previous section addressed the constitutional framework for committees of inquiry, this section describes single aspects of the right of inquiry in greater detail. The chronological proceedings of committees of inquiry are discussed first.

\subsubsection{Chronological proceedings}

Article 226 TFEU requires that the initial impetus for an inquiry be a request of at least a quarter of the members of the European Parliament. This request must specify precisely the subject of the inquiry and include a detailed statement of the grounds for it. ${ }^{93} \mathrm{~A}$ proposal to establish a committee of inquiry has to win a majority in the Conference of Presidents. ${ }^{94}$ The Conference of Presidents does not only consider whether establishing a committee of inquiry is a good idea from a political point of view. It is also tasked with verifying

\footnotetext{
91 Majone (2005), p. 80.

92 Cf. Senden (2003), p. 370.

93 Cf. Rule 185 (3) Rules of Procedure of the European Parliament.

94 The Conference of Presidents consists of the President of the Parliament and the chairmen of the political groups, who may arrange to be represented by a member of their group. The Conference of Presidents takes decisions on the organization of Parliament's work. Cf. Rule 23 and 24 of the Rules of Procedure of the European Parliament.
} 
whether the proposal is legally admissible in the light of Article 226 TFEU. It follows from this Treaty provision that the European Parliament cannot establish committees of inquiry on any issue it pleases, as it limits the scope of the right of inquiry to 'alleged contraventions or maladministration in the implementation of Union law'. The right of inquiry thus is specifically designed to investigate alleged abuses. The Interinstitutional Agreement further specifies that the alleged abuses must be the act of 'an institution or a body of the European Communities, of a public administrative body of a Member State or of persons empowered by Community law to implement that law'. Another restriction on the scope of the right of inquiry is the sub judice rule. Following this rule, the Parliament may not establish a committee of inquiry if at the same time (i.e. at the moment of establishment) legal proceedings are ongoing on the same facts before a national or a Union court. ${ }^{95}$

If the Conference of Presidents ultimately supports a request to set up a committee of inquiry, it submits the request for approval to the plenary. ${ }^{96}$ The plenary subsequently has to approve this proposal by majority vote. ${ }^{97}$ After the approval, the decision to establish a committee of inquiry, which must specify the purpose of the inquiry and the time limit for submission of the report, shall be published in the Official Journal of the European Union. ${ }^{98}$ The time limit for submission of the final report may not exceed twelve months. However, the European Parliament can, by means of a reasoned decision, extend the twelve month period twice by three months. ${ }^{99}$ Upon a proposal of the Conference of Presidents ${ }^{100}$, the plenum determines the number of members and the composition of the committee of inquiry. The (vice-) chairperson(s) and rapporteur(s) are elected by the committee of inquiry itself during its constituent meeting. ${ }^{101}$ The composition of the inquiry committee shall, as far as possible, reflect the composition of the Parliament. ${ }^{102}$

After these formalities have been concluded, the actual inquiry can begin. As a general rule, committees of inquiry begin by collecting information on the subject matter under investigation. The Interinstitutional Agreement assigns powers to committees of inquiry concerning the gathering of evidence, such as the right to invite witnesses and the right to request documents. ${ }^{103}$ Inquiry committees can furthermore collect evidence through on-the-spot fact-finding visits.

The chairperson leads the internal organization of the committee of inquiry. He or she represents the committee both within the Parliament (in the Conference of Committee Chairs) and outside the Parliament. He or she can further have a

\footnotetext{
${ }^{95} \mathrm{Cf}$. Section 2.4 .3 on the scope of the right of inquiry.

${ }^{96} \mathrm{Cf}$. Rule 185 (3) Rules of Procedure of the European Parliament.

${ }_{97} \mathrm{Cf}$. Rule 176 Rules of Procedure of the European Parliament.

${ }^{98} \mathrm{Cf}$. Article 2 (1) IIA.

${ }^{99} \mathrm{Cf}$. Article 2 (4) IIA.

${ }^{100} C f$. Rule 186 (1) Rules of Procedure of the European Parliament.

${ }^{101} \mathrm{Cf}$. Article 2 (1) IIA and Rule 185 (5) Rules of Procedure of the European Parliament. In practice, these positions are shared out by agreement among political groups on the basis of the number of members within each political group. $C f$. Corbett/Jacobs/Shackleton (2011), p. 147.

${ }^{102}$ Rule 186 (1) Rules of Procedure of the European Parliament.

${ }^{103} \mathrm{Cf}$. Section 2.4.4 on the powers of committees of inquiry.
} 
powerful role in shaping the agenda of the committee and presides over the committee meetings. ${ }^{104}$ It is the committee rapporteur's task to submit a draft report to the committee, which can be amended by the committee members. ${ }^{105}$ Members of a committee of inquiry can deliver a minority opinion on the report. ${ }^{106}$ Committees of inquiry generally attach a motion for resolution to their report, addressed to EU institutions or bodies, or Member States. The committee of inquiry ceases to exist on the submission of its report. ${ }^{107}$ Finally, the rapporteur presents the report of the inquiry committee to the Parliament prior to a plenary debate, which is generally held at the part-session following the submission of the report.

\subsubsection{Establishment and composition of committees of inquiry}

\subsubsection{Quorum}

Article 226 TFEU stipulates that the European Parliament may set up a committee of inquiry at the request of a quarter of its members. Although the signatures of a quarter of the MEPs is necessary to put forward a proposal, the word 'may' implies that the Parliament is not obliged to set up a committee even if the requisite number of signatures is obtained. ${ }^{108}$ A proposal to establish a committee of inquiry has to win majority support in the Conference of Presidents ${ }^{109}$, which then submits a proposal for approval to the plenary. The plenary subsequently has to approve this proposal by majority vote. ${ }^{110}$ Before the right of inquiry was laid down in primary law, inquiry committees could be established by a parliamentary minority. Rule 109 (3) of the Rules of Procedure 1987 stipulated: 'Parliament shall, on a motion by one quarter of its Members [...], set up a committee of inquiry'. This wording was replaced by the current wording of Article 226 TFEU: 'Parliament may, at the request of a quarter of its component Members, set up a committee of inquiry'. The situation before 1993 was similar to the current system in Germany, where the right of inquiry is designed to guarantee the rights of a parliamentary minority. Article 44 of the German Basic Law (Grundgesetz) stipulates that a committee of inquiry must be established upon the request of a quarter of the members of the Bundestag. The rationale for giving a parliamentary minority the right to establish a committee of inquiry follows from the fear that if the establishment of a committee of inquiry depends on the willingness of a coalitional majority, the oppositional right to scrutinize government action may be illusory. However, since the relations between EU executive actors and the European Parliament

\footnotetext{
${ }_{104}$ Cf. Corbett/Jacobs/Shackleton (2011), p. 147.

105 Cf. Corbett/Jacobs/Shackleton (2011), p. 147.

106 Cf. Rule 185 (10) Rules of Procedure.

107 Cf. Article 2 (4) IIA.

108 See also: Shackleton (1998), p. 117; Höpfner (2004), pp. 92-95; Wiersma (2004), p. 227; Berner (2004), p. 199.

109 The Conference of Presidents consists of the President of the Parliament and the chairmen of the political groups, who may arrange to be represented by a member of their group. The Conference of Presidents takes decisions on the organization of Parliament's work. Cf. Rule 23 and 24 of the Rules of Procedure of the European Parliament.

${ }^{110} \mathrm{Cf}$. Rule 176 Rules of Procedure of the European Parliament.
} 
are not as close as the relations between many national governments and 'their' respective majorities in national parliaments, it may be argued that oppositional rights are in less need of protection on the EU level. ${ }^{111}$ The requirement of a majority vote further guarantees a prudent use of the right of inquiry, whereas an overly frequent use of the right of inquiry could turn the right of inquiry into a dull weapon in the armoury of the Parliament.

\subsubsection{Formal requirements}

Article 2 (1) IIA specifies that the decision to set up a temporary committee of inquiry shall be published in the Official Journal of the European Communities (at present: the Official Journal of the European Union), stating in particular its purpose and the time limit for submission of its report. Rule 185 (3) of the Rules of Procedure stipulates that the request to set up a committee of inquiry must precisely specify the subject of the inquiry and include a detailed statement of the grounds for it. The subject of the inquiry, as defined by a quarter of the members of the European Parliament, is not open to amendments. ${ }^{112}$ The fact that a minority proposal cannot be amended by a majority marks some sort of protection for the proposing minority. Either the minority proposal is accepted, or it is rejected. It cannot be changed by the majority. This is, of course, a rather simplistic and formalistic way of putting it. The Conference of Presidents and the plenary do de facto have the ability to adapt the proposal by replying to the requestors: "we only agree with the establishment of a committee of inquiry if you file a new request and adapt the initial proposal”.

The publication of the precise subject and a detailed statement of the grounds is more than a solemn public announcement. The content of the decision to set up a committee of inquiry specifically defines the mandate beyond which an inquiry committee may not investigate. It is of great importance that the subject and the purpose of the inquiry be described sufficiently accurately, since this cannot be changed during the inquiry. The rationale behind this rule lies therein that a committee of inquiry may not depart from the mandate conferred on it by a parliamentary majority.

\subsubsection{Duration of inquiries}

Article 2 (4) IIA determines the maximum duration of inquiries. The temporary committee of inquiry ceases to exist on the submission of its report within the time limit laid down when it was set up or at the latest twelve months from the date when it was set up. In addition, a temporary committee of inquiry ceases to exist at the close of the parliamentary term. Hence, one and the same inquiry may not be spread out over more than one parliamentary term. The Parliament can, by means of a reasoned decision, extend the twelve month period twice by three months, again provided that this takes place within one parliamentary term. Article 2 (5) IIA specifies that a committee of inquiry may only be re-established for matters into which an inquiry has

\footnotetext{
111 See also: Höpfner (2004), pp. 94-95.

$112 C f$. Rule 185 Rules of Procedure of the European Parliament.
} 
already been held at least twelve months after the close of that inquiry and only after new facts have emerged.

\subsubsection{Composition of committees of inquiry}

The Interinstitutional Agreement stipulates that it is the Parliament's task to determine the composition of committees of inquiry. ${ }^{113}$ The Parliament has laid down the procedure for this. According to Rule 25 (7) of its Rules of Procedure, the Conference of Presidents is responsible for determining the composition of committees of inquiry. The proposal from the Conference of Presidents in this regard is open to amendments and the composition of the committees shall, as far as possible, reflect the composition of Parliament. ${ }^{114}$ The composition of the three committees of inquiry held since 1993 shows that the number of MEPs within a committee of inquiry varies from 17 in the case of the Transit inquiry to 22 members in the case of the BSE inquiry (excluding substitute members). ${ }^{115}$ Rule 185 (5) of the Rules of Procedure stipulates that a committee of inquiry shall elect its chair and two vice-chairs and appoint one or more rapporteurs. Practice shows that the chair and the rapporteur come from different political groups. ${ }^{116}$ The chair leads the committee of inquiry and plays an important role during the hearings, whereas the rapporteur writes the report and submits draft conclusions to the committee, which can be amended by the committee members. ${ }^{117}$

Political groups (and the non-attached Members) may further appoint a number of permanent substitutes for each committee equal to the number of full members representing them on the committee. These substitute members normally have full speaking and voting rights if acting as a replacement for an absent 'full' member. ${ }^{118}$

\subsubsection{Staff of committees}

Committees of inquiry are assisted by a staff. Compared to the US Congress, but not to the national parliaments of the Member States, the staffs of committees of the European Parliament are relatively small. Committees of the European Parliament normally have four to ten administrators, one or two committee assistants who look after the logistics of the meetings, and a number of secretaries. ${ }^{119}$ The committee staff assists rapporteurs with background research and have an important role in briefing members on the past activities and positions adopted within the committee. ${ }^{120}$ In addition, other officials attend committee meetings. The Legal Service of the Parliament advises

\footnotetext{
113 Article 2, Paragraph 1, IIA.

114 Rule 177, Paragraph 1, Rules of Procedure of the European Parliament.

115 The committee of inquiry into the Community Transit Regime consisted of 17 Members and 17 substitutes, against 19 Members and 19 substitutes in the committee of inquiry into BSE and 22 members and 15 substitutes in the committee of inquiry into the crisis of the Equitable Life Assurance Society. Section 2.5 discusses these inquiries.

116 Cf. Section 2.5. See also: Wiersma (2004), p. 227.

117 Wiersma (2004), p. 227.

118 Cf. Rule 187 (1) Rules of Procedure of the European Parliament.

119 Corbett/Jacobs/Shackleton (2011), p. 151.

${ }_{120} \mathrm{Cf}$. Corbett/Jacobs/Shackleton (2011), p. 151-152.
} 
committees on legal questions, the Directorate-General for Information is represented and researchers from the Policy departments working alongside the committee secretariats also follow the meetings. Committee members are further assisted by staff members from their respective political groups and by their personal assistants.

The three committees of inquiry established since 1993 have had a secretariat existing of one head of secretariat, three administrators and a number of assistants and secretaries. This might look rather small compared to other committees of the European Parliament, but one should not forget that the staffs of committees of inquiry concentrate exclusively on the inquiry, whereas the staffs of standing committees must handle a wide variety of issues.

\subsubsection{Scope of the right of inquiry}

Which matters may, and which matters may not be investigated by a committee of inquiry? This sub-section addresses the scope of the right of inquiry.

The wording of Article 226 TFEU limits the scope of the right of inquiry in the first place to 'alleged contraventions or maladministration in the implementation of Union law'. Secondly, the Interinstitutional Agreement states that the alleged abuses must be the act of an institution or a body of the European Communities, of a public administrative body of a Member State or of persons empowered by Community law to implement that law. Thirdly, the European Parliament may not establish a committee of inquiry if at the same time legal proceedings are ongoing on the same facts before a national or a Union court. This is the sub judice rule. The restrictions on the scope of the parliamentary right of inquiry are discussed separately hereafter.

\subsubsection{Object of investigation}

In contrast with the wide variety of matters that inquiry committees in many national Member States may investigate, the scope of what may be investigated by committees of inquiry of the European Parliament is rather narrow. There are five restrictions on what a committee of inquiry may investigate. Committees of inquiry may only be set up to investigate (I) alleged contraventions or maladministration, (II) in the implementation of Union law, (III) which are concrete and clearly defined, (IV) which have occurred in the past, and (V) which are not sub judice. These restrictions are discussed separately below.

\section{I. alleged contraventions or maladministration}

Firstly, there must be allegations of 'contraventions' or 'maladministration'. The word 'contraventions' suggests violation of rules (in casu of EU law), but the meaning of the word 'maladministration' is less clear. 'Maladministration' is neither defined by primary nor by secondary Union law. However, in his 1995 Annual Report, the European Ombudsman explained the term as follows: "Clearly there is maladministration if a Community institution or body fails to act in accordance with the Treaties and with the Community acts that are binding upon it, or if it fails to observe the rules and principles of law 
established by the Court of Justice and Court of First Instance". ${ }^{121}$ The Ombudsman went on to say that many other things may also amount to maladministration, including administrative irregularities, administrative omissions, abuses of power, unfairness, malfunction or incompetence, discrimination, avoidable delays, refusal to provide information, negligence, et cetera. ${ }^{122}$ Parliament endorsed this definition in its resolution of 16 July $1998 .{ }^{123}$ In 1999 there further was a correspondence between the Ombudsman and the Commission which made clear that the Commission also agreed with this definition. ${ }^{124}$

The restriction to 'alleged contraventions or maladministration' limits the scope of investigation substantially. Due to this stipulation, the right of inquiry cannot be used as an instrument to examine and evaluate general policy areas, and it further cannot be used to investigate matters solely with a view to making proposals for future policy or legislation (the 'non-accountability investigations'). ${ }^{125}$ Such inquiries are inadmissible as long as there are no allegations of 'contraventions or maladministration'. This is at odds, for example, with the Select Committees in the UK, where every so-called Departmental Select Committee is responsible for the scrutiny of a government department. The Departmental Select Committees' role is to examine the 'expenditure, administration and policy' of the relevant government department. This, as a matter of course, implies a far wider scope of investigation than the scope of committees of inquiry of the European Parliament. Investigations into general policy matters are normally conducted by other committees of the European Parliament, namely the temporary special committees and the standing committees ${ }^{126}$.

\section{II. in the implementation of Union law}

Secondly, the right of inquiry is restricted to alleged contraventions or maladministration 'in the implementation of Union law'. Under the former Article 193 EC Treaty, the right of inquiry was further restricted to matters of 'Community law', thus excluding issues under the second and the third pillars, the Common Foreign and Security Policy (CFSP) and Justice and Home Affairs (JHA) respectively. As a consequence of this restriction, on at least two occasions the Parliament was only able to set up a special committee where it perhaps would have preferred to establish a committee of inquiry. ${ }^{127}$ However, the Treaty of Lisbon has abandoned the three-pillar structure in favour of a single corpus of the Union. The current Treaty provision (Article 226 TFEU) enables the Parliament to investigate issues under the former second and third pillar within the framework of the right of inquiry. The second restriction on the object of investigation has therefore, to a substantial extent, disappeared.

\footnotetext{
${ }^{121}$ European Ombudsman (1996). Annual Report for 1995 (22.4.1996), p. 8.

122 Ibid. pp. 8-9.

123 OJ C 292, 21.9.1998, p. 168.

124. European Ombudsman (2000). Annual Report for 1999 (1.4.2000), p. 19.

125 See also: Höpfner (2004), p. 104.

126 Chapter 3 addresses the temporary special committees and Chapter 4 the standing committees of the European Parliament.

${ }^{127} \mathrm{Cf}$. The investigations into Echelon and CIA flights (Sections 3.6.2 and 3.6.5).
} 
The only restriction that is left within this category is that the inquiry must be connected to 'the implementation of Union law', which includes both the transposition and the application of Union law but excludes the implementation of national and international law outside the EU sphere. In 2003, as a result of maritime disasters which had occurred in European waters, the Parliament wanted to examine in detail the causes and the effects of these disasters. However, since many regulations in the field of maritime safety fall under the authority of the International Maritime Organization (IMO), and consequently lie outside the EU sphere, the Parliament decided to establish a temporary special committee instead of a temporary committee of inquiry. ${ }^{128}$

\section{III. which are concrete and clearly defined}

Thirdly, the allegations of contraventions and/or maladministration of Union law must be concrete and clearly defined. ${ }^{129}$ This condition cannot be considered to be fulfilled, for example, for a blanket inquiry into all policy within the Directorate-General for Agriculture and Rural Development of the European Commission. Due to this restriction, the Conference of Presidents declined a proposal to set up a committee of inquiry into 'the incorporation into national law of Community legislation on the environment' in 1990. ${ }^{130}$ The proposal did not contain a concrete allegation of a contravention or of maladministration, but rather requested general scrutiny of the incorporation into national law of Community legislation on the environment. The Conference of Presidents therefore referred the submitters of the proposal to one of the standing committees, namely the committee on Legal Affairs and Citizens' Rights, whose task it is to draw up annual reports on the application of Community law. ${ }^{131}$

The three inquiries conducted since 1993 were targeted at specific issues, namely at allegations of contraventions or maladministration in the Community Transit System ${ }^{132}$, at alleged contraventions or maladministration in the implementation of Community law in relation to $\mathrm{BSE}^{133}$, and at the application of Community law in relation to the crisis of the Equitable Life Assurance Society. ${ }^{134}$

IV. which have occurred in the past

The phrase 'alleged contraventions or maladministration in the implementation of Union law' denotes retrospective investigations, since there must be allegations of contraventions of Union law which have occurred in the past. The wording of Article 226 TFEU thus excludes possible future contraventions which cannot be considered to have occurred yet. As a matter of course, it does not necessarily exclude contraventions which are ongoing while the inquiry is taking place.

\footnotetext{
128 Cf. Section 3.6.4.

129 Cf. Beckedorf (1995), p. 320.

130 Ibid. p. 276.

131 OJ C 284, 12.11.1990, p. 2.

${ }^{132}$ Cf. Section 2.5.1.

${ }^{133}$ Cf. Section 2.5.2.

${ }^{134}$ Cf. Section 2.5.3.
} 
The fifth restriction on the scope of the right of inquiry is the sub judice rule. Article 226 TFEU stipulates that the Parliament cannot establish committees of inquiry 'where the alleged facts are being examined before a court and while the case is still subject to legal proceedings'. Article 2 (3) IIA specifies: 'A temporary committee of inquiry may not investigate matters at issue before a national or Community court of law until such time as the legal proceedings have been completed'. The rationale of this provision is directly connected to the doctrine of the separation of powers and the independence of the judiciary. The sub judice rule serves to ensure that legal proceedings are not prejudiced by parliamentary activity.

When are parliamentary inquiries on the European level inadmissible in the light of the sub judice rule? The wording of Article 226 TFEU implies that the European Parliament may not establish a committee of inquiry if at the same time (i.e. at the moment of establishment) legal proceedings are ongoing on the same facts. An inquiry into a matter which initially was not being examined before a court, but which at some stage becomes an issue before a court when a committee of inquiry has already been established, is thus admissible in the light of Article 226 TFEU. The wording of Article 2 (3) IIA, however, implies an absolute prohibition of simultaneous parliamentary and judicial investigations into the same matter, even if the judicial investigations start after the establishment of the inquiry committee. Article 226 TFEU and Article 2 (3) IIA thus outline a different scope of the sub judice rule and the question arises which of these provisions has precedence. The answer is Article 226 TFEU, since a provision in the Interinstitutional Agreement cannot have the legal effect of narrowing the scope of the right of inquiry as defined in the higher-ranking Treaty provision. It thus follows that the sub judice rule is only applicable with regard to legal proceedings at the point in time when the committee of inquiry is established.

The term 'court' is construed extensively in Article 2 (3) IIA and includes both Union and national courts ("A temporary committee of inquiry may not investigate matters at issue before a national or Community court of law until such time as the legal proceedings have been completed'). It is thus important to understand what is meant by the term 'court'. It may be clear that the Court of Justice of the European Union at the European level is a court, but what exactly is a national court? Are the Member States free to decide themselves what a court is, or is 'court' a Union concept? For the purposes of the preliminary reference procedure (ex Article 267 TFEU), the Court of Justice has ruled that the term 'court or tribunal of a Member State' is subject to an autonomous Union interpretation. Several criteria defining a court can be found in the Court of Justice's case law. In general, bodies must be established by law, be independent, have a binding jurisdiction, use inter partes procedures, and apply rules of law. ${ }^{135}$ It is reasonable to assume that the term 'court' has

\footnotetext{
135 Derived from: Chalmers/Monti (2008), pp. 293-294. These criteria were first established in: Case C-61/65, Vaassen v Beambtenfonds voor het Mijnbedrijf, and upheld ever since. Cf. more recently: Case C-53/03, Syfait v Glaxo Smith Kline.
} 
the same meaning for the purpose of Article 226 TFEU as the term 'court or tribunal of a Member State' for the purpose of Article 267 TFEU. It thus follows that the same criteria are applicable.

The fact that the term 'court' in Article 226 TFEU means both EU and national courts ( $c f$. Article 2 (3) IIA) is problematic, since it might have the effect of paralysing the right of inquiry. A practical example may clarify this. Following the sub judice rule of Article 226 TFEU and Article 2 (3) IIA, the parliamentary inquiry into BSE ( $c f$. Section 2.5.2) could have been partially frustrated by a 'simple' claim for damages by a British farmer before a civil law court. Even more perversely, the UK government could have provoked such civil proceedings to prevent the European Parliament from investigating alleged contraventions or maladministration on its part.

In the first place, it is up to the Parliament to decide whether or not specific facts are sub judice. If the Parliament observes that a proposal to establish a committee of inquiry might be problematic from this perspective, it has three options. Firstly, it can choose to refrain from establishing a committee of inquiry by refusing the proposal. Secondly, it can refuse the proposal, but table a new proposal which leaves out the problematic parts of the future committee's mandate. ${ }^{136}$ Lastly, it can choose to approve the proposal, in breach of the sub judice rule. By choosing the latter option - approving the establishment of an 'illegal' inquiry - the Parliament runs the risk that the Court of Justice might close down the inquiry. The Court of Justice thus has the final say on the admissibility of a decision to establish a committee of inquiry in light of the sub judice rule.137 In other words: the European Parliament proposes, the Court of Justice of the European Union ultimately disposes.

Furthermore, during the negotiations on the Interinstitutional Agreement, the Commission insisted that an inquiry into alleged infringements of the Treaties would be incompatible with a Commission pre-litigation procedure. ${ }^{138}$ This did not, however, result in an absolute prohibition of investigations into matters being simultaneously examined by the Commission as part of such a prelitigation procedure. Article 2 (3) IIA stipulates that in such cases the temporary committee of inquiry shall take all necessary steps to enable the Commission fully to exercise the powers conferred on it by the Treaties'.

The wording of Article 226 TFEU suggests that the sub judice rule solely concerns the establishment of committees of inquiry. However, a teleological interpretation reveals a wider scope of this rule. It is reasonable to assume that the sub judice rule is not only applicable when establishing a committee of inquiry, but also for its duration. Committees of inquiry should refrain from investigating matters which are sub judice. This should - at least in theory - not be a problem, since a committee of inquiry may not investigate issues which fall

\footnotetext{
136 A new proposal must then be tabled, as it is not possible to amend the subject of the inquiry as defined by at least a quarter of the members of the European Parliament (see also Section 2.4.2.2).

${ }_{137}$ Cf. Section 2.4.5.1.

138 European Parliament (1995). Committee on Institutional Affairs. Report on the right of inquiry of the European Parliament (A4-0003/95, 12.1.1995), p. 13.
} 
outside its mandate as conferred on it by the plenary. Thus, if a mandate is not sub judice, and the committee of inquiry does not exceed its mandate, its activities cannot be sub judice either.

An example may clarify the above. Suppose a committee of inquiry is investigating the alleged abuse of EU agricultural funds throughout Europe. The mandate of the inquiry committee is to investigate whether abuses are taking place and, if so, who is responsible for them. Due to national proceedings - let's say in Germany - into specific allegations of abuses in Bavaria, these specific cases fall outside the scope of the right of inquiry. In this case, it would be reasonable to assume that the committee of inquiry may not investigate the specific alleged abuses in Bavaria which are subjudice.

\subsubsection{Subject of investigation}

Article 226 TFEU does not specify which authorities can be the subject of an inquiry. The wording of this Treaty provision ('alleged contraventions or maladministration in the implementation of Union law', (my italics, CNS)) suggests that the European Parliament can exercise its right of inquiry solely in relation to EU executive actors, as only EU executive actors can implement Union law. Other actors, such as third countries (i.e. non-EU Member States), cannot implement EU law and therefore fall outside the scope of the right of inquiry. This restriction on the scope of the right of inquiry has proved to be an obstacle in practice. The alleged involvement of third countries was one of the reasons why the European Parliament preferred to establish an ordinary temporary committee rather than a committee of inquiry to investigate the Echelon interception system. ${ }^{139}$

Article 2 (1) IIA mentions three categories of subjects of inquiries: (1) institutions and bodies of the European Communities, (2) public administrative bodies of Member States, and (3) persons empowered by Community law to implement that law. The first category includes the Commission and the Council as 'main executive actors' of the European Union. The reference to 'EU bodies' further implies that European agencies fall within this category. Although to date no European agencies have been the subject of a parliamentary inquiry, their increasing number and powers - including powers to adopt decisions that are legally binding for third parties - require appropriate accountability mechanisms to keep them in check. ${ }^{140}$ The right of inquiry thus may be an important tool for the European Parliament to hold such European agencies to account in the future. The second category ("public administrative bodies of Member States') includes all Member State bodies which can implement Union law. National governments are key players in this respect. However, other public bodies, such as geographically decentralized bodies (i.e. provinces or municipalities) and functionally decentralized bodies

\footnotetext{
139 European Parliament (2001). Echelon committee. Working document in preparation for a report on the existence of a global system for intercepting private and commercial communications (ECHELON interception system) (PE 300.153, 4.5.2001), p. 9. Section 3.6.2 addresses the Echelon investigation.

${ }^{140}$ For a description of the 'explosion of agencies' in the European Union, $c f$. Curtin (2009), pp. 146-150. For further reading on the accountability of EU agencies, $c f$. Busuioc (2010a).
} 
(i.e. national agencies endowed with executive power) are included as well insofar as they can implement EU law. This second category is important in view of the fact that the bulk of EU law is implemented by executive actors in this category. The third category ("persons empowered by Community law to implement that law') is the residual category, encompassing both legal persons and natural persons insofar as they can implement EU law. In the absence of an explanatory memorandum elucidating the single provisions of the agreement, it unfortunately remains unclear which persons fall into this category.

\subsubsection{Powers of committees of inquiry}

The effectiveness of the right of inquiry depends inter alia on the powers held by committees of inquiry. In order to gather relevant information, committees of inquiry should, for example, be able to hear persons and gain access to relevant documents. This sub-section addresses the powers of committees of inquiry of the European Parliament.

\subsubsection{The right to call witnesses}

Committees of inquiry of the European Parliament can invite a wide range of persons to give evidence before them. However, it is unclear whether they can oblige witnesses to appear, and, if they can, whether they can penalize witnesses should they refuse to appear. Article 3 IIA lays down different arrangements for three categories of witnesses: (1) members of an institution or a body of the European Union or the government of a Member State (Article 3 (2) IIA), (2) officials and servants (Article 3 (3) IIA), and (3) other persons (Article 3 (8) IIA). These categories of witnesses are discussed separately below.

\section{(1) Members of an institution or a body of the European Union or the government of a Member State}

On the basis of Article 3 (2) IIA, committees of inquiry may invite an institution or a body of the European Union or the government of a Member State to designate one of its members to take part in its proceedings. On the basis of this provision, committees of inquiry can invite, for example, Commissioners, the High Representative of the Union for Foreign Affairs and Security Policy, the President of the European Council, the President-in-office of the Council of the European Union, directors of EU agencies, national ministers, national secretaries of state and heads of government.

According to Höpfner, Commissioners and Council members are under a legal duty to accept such an invitation. She draws this conclusion by referring to the preamble of the Interinstitutional Agreement, which includes the phrase: "whereas [...] it is essential that the Member States and the institutions and bodies of the European Communities take all steps to facilitate the performance of those duties”. ${ }^{141}$ In Höpfner's view, this phrase suggests a legal duty for Commissioners and Council members to appear before committees of inquiry. This view must be rejected for the simple reason that a provision in a preamble cannot have the effect of amending concrete provisions in the main text. At

${ }^{141}$ Höpfner (2004), pp. 202-203. 
best, a preamble may serve as some sort of guideline on how to interpret the legal provisions in the main text. However, concrete rights and obligations cannot be derived from it. Concrete rights and obligations are laid down in the main text of the Interinstitutional Agreement, in casu in Article 3 (2) IIA.

Höpfner's view is not corroborated by the wording of Article 3 (2) IIA. Unlike verbs such as 'require' and 'summon', the verb 'invite' does not indicate a legal duty. Anyone can invite a Commissioner to appear, but whether the Commissioner shows up is of course another matter altogether. Moreover, Höpfner's claim is at odds with the original intent of the 'founding fathers' of the Interinstitutional Agreement. During the negotiations on the Interinstitutional Agreement, it became clear that a right of summons vis-à-vis this category of witnesses was a bridge too far for the Council. ${ }^{142}$ For this reason, the initial proposal of the European Parliament, which included a general right of summons, was rejected and replaced by the current provision. ${ }^{143}$ In its report on the results of the negotiations on the Interinstitutional Agreement, even the Parliament itself acknowledged that the negotiations did not lead to a right of summons vis-à-vis witnesses of the first category. ${ }^{144}$

The Interinstitutional Agreement thus does not compel witnesses of the first category to appear before committees of inquiry. There may, however, be other legal provisions (outside the Interinstitutional Agreement) which place these witnesses under a duty to appear. Such is the case, for example, for members of the Commission. Article 230 TFEU stipulates that ' $(\mathrm{t})$ he Commission shall reply orally or in writing to questions put to it by the European Parliament or by its Members'. A reasonable interpretation of this provision leads - in conjunction with the duty of sincere cooperation - to the conclusion that Commissioners are under a legal duty to appear before a committee of inquiry if the latter so requests.

${ }_{142}$ Shackleton (1998), p. 119; In its first Draft Decision on European Parliament temporary Committees of Inquiry the Council proposed the following text for Article 3 (2): 'The TCI (Temporary Committee of Inquiry, CNS) may address a request to attend one of its meetings to a member of an institution of the European Communities or of a Government of a Member State via its Permanent Representation to the European Communities. The institutions and the Member States concerned shall consider such requests case by case and in a spirit of cooperativeness with the European Parliament'. Cf. Proposal of the Council on parliamentary committees of inquiry (SN 1338/94, 3.2.1994). In its second Draft Decision on European Parliament temporary Committees of Inquiry the Council proposed a more concise wording: 'Der nichtständige Untersuchungsausschuß kann an ein Mitglied eines Organs der Europäischen Gemeinschaften oder an ein Mitglied der Regierung eines Mitgliedstaats eine Einladung zur Teilnahme an einer seiner Sitzungen richten'. $C f$. Draft Decision on European Parliament temporary Committees of Inquiry (no. 2, SN 3982/94, 22.9.1994) (only available in German).

${ }_{143} C f$. Shackleton (1998), pp. 119-120; Wiersma (2004), p. 227.

${ }^{144}$ Whereas Article 3 (3) IIA regarding witnesses of the second category was described as 'a fundamental right to require (CNS) an official of the Community or of a Member State to appear before a committee of inquiry', Article 3 (2) IIA regarding witnesses of the first category was described as 'the right to invite $(C N S)$ members of institutions or bodies of the European Union or of the governments of the Member States with political approval'. $C f$. European Parliament (1995). Committee on Institutional Affairs. Report on the right of inquiry of the European Parliament (A4-0003/95, 12.1.1995), p. 13. 


\section{(2) Officials and servants}

The second category of witnesses includes national and EU officials and servants. Article 3 (3) IIA stipulates:

'On a reasoned request from the temporary committee of inquiry, the Member States concerned and the institutions or bodies of the European Communities shall designate the official or servant whom they authorize to appear before the temporary committee of inquiry, unless grounds of secrecy or public or national security dictate otherwise by virtue of national or Community legislation.

The officials or servants in question shall speak on behalf of and as instructed by their Governments or institutions. They shall continue to be bound by the obligations arising from the rules to which they are subject.'

In comparison with the witnesses of the first category, the position of committees of inquiry is somewhat stronger with regard to witnesses of this category, since Member States and institutions or bodies of the European Union can be placed under a duty to designate an official or servant to a committee of inquiry. However, this still falls short of a general right of summons, since it remains in the hands of the Member State, the institution or the body of the European Union to decide who to designate. Committees of inquiry thus cannot oblige authorities to designate specific officials or servants. It is quite remarkable that the European Ombudsman, who is appointed by the European Parliament and whose task it is to investigate complaints about maladministration in the institutions and bodies of the European Union, has a stronger position than committees of inquiry in this respect. The European Ombudsman can summon any official and servant of the European Union to testify before him. ${ }^{145}$

Article 3 (3) and Article 3 (5) IIA include exceptions to the general obligation to designate officials or servants to a committee of inquiry upon the request of the latter.

\section{Article 3 (3) IIA}

The obligation to designate an official or servant is firstly restricted by Article 3 (3) IIA. Member States and institutions or bodies of the European Union are under a duty to designate officials or servants 'unless grounds of secrecy or public or national security dictate otherwise by virtue of national or Community legislation'. Whereas it is understandable that grounds of secrecy or security may justify a refusal to answer single questions ( $c f$. Section 2.4.4.2),

\footnotetext{
145 The last sentence of Article 3 (2) of the 'Decision of the European Parliament on the regulations and general conditions governing the performance of the Ombudsman's duties' reads: Officials and other servants of Community institutions and bodies must testify at the request of the Ombudsman; they shall continue to be bound by the relevant rules of the Staff Regulations, notably their duty of professional secrecy. The European Ombudsman Statute was adopted by Parliament on 9 March 1994 (OJ L 113, 4.5.1994, p. 15) and amended by its decisions of 14 March 2002 (OJ L 92, 9.4.2002, p. 13) and 18 June 2008 (OJ L 189, 17.7.2008, p. 25).
} 
it is questionable that these grounds may even justify a refusal to appear before a committee of inquiry. It is arguable that, even without the provision of Article 3 (3) IIA, secrecy and security are already sufficiently protected. Firstly, because witnesses may refuse to answer single questions on the grounds of secrecy or public or national security ( $c f$. Section 2.4.4.2). Secondly, because there are sufficient safeguards to prevent officials and servants from disclosing sensitive information in violation of 'national or Community legislation'. An example of such a safeguard is the option of having legal assistance during a committee of inquiry hearing. Nothing prevents witnesses from invoking legal assistance when giving evidence. Another safeguard is the fact that witnesses, even those who are under a legal duty to appear before a committee of inquiry, may choose to provide testimony in camera (Article 2 (2) IIA). Article 4 (1) IIA stipulates that evidence given in camera may not be made public if it contains material of a secret or confidential nature.

\section{Article 3 (5) IIA}

Member States can further refuse to designate national servants to appear before a committee of inquiry if Article 3 (5) IIA is applicable. The first part of this provision stipulates that Article 3 (3) IIA 'shall be without prejudice to any other provisions of the Member States which prohibit officials from appearing'. This means that national legal provisions can justify a refusal on the part of national authorities to designate a servant to a committee of inquiry. The second part of Article 3 (5) IIA states that Member States shall inform the European Parliament of obstacles arising in this perspective, which amounts to a duty on the part of national governments to give reasons for a refusal to designate a civil servant. ${ }^{146}$

The implications of Article 3 (5) IIA can be illustrated by the example of a German civil servant being invited to testify before a committee of inquiry of the European Parliament. As a general rule, German civil servants may only give testimony if they are explicitly authorized by their superiors giving them a speaking permit (Aussagegenehmigung). According to Paragraph 68 (1) of the German Civil Servants Act, such a speaking permit may be refused when the disclosure of information on the basis of that permission 'would cause disadvantages to the well-being of the federation or one of the federal states, or when it would seriously jeopardize or severely hamper the performance of public duties and responsibilities'. ${ }^{147}$ It follows from Article 3 (5) IIA that a refusal on the part of the German government to grant a speaking permit to a civil servant takes precedence over the obligation of Article 3 (3) IIA to designate a civil servant to the European Parliament committee of inquiry. However, this does not mean that the German government can freely refuse to

\footnotetext{
146 The second part of Article 3 (5) IIA reads: 'an obstacle arising from reasons of secrecy, public or national security or the provisions referred to in the first subparagraph shall be notified to the European Parliament by a representative authorized to commit the Government of the Member State concerned or the institution.'

${ }^{147}$ The original German wording of Paragraph 68 (1) German Civil Servants Act reads: 'Die Genehmigung, als Zeugin oder Zeuge auszusagen, darf nur versagt werden, wenn die Aussage dem Wohle des Bundes oder eines deutschen Landes Nachteile bereiten oder die Erfüllung öffentlicher Aufgaben ernstlich gefährden oder erheblich erschweren würde.'
} 
grant speaking permits to civil servants. It follows from the duty of sincere cooperation that national governments may not abuse this provision in order to prevent national civil servants from appearing before a committee of inquiry of the European Parliament.

\section{No formal mechanisms to enforce and/or to impose sanctions}

The legal position of committees of inquiry is stronger with regard to witnesses from the second category. Member States and institutions and bodies of the European Union can be required to designate an official or servant to a committee of inquiry. However, this still falls short of a general right of summons, since it remains in the hands of the Member State, the institution or the body of the European Union to decide which person to designate. Furthermore, committees of inquiry lack legal mechanisms to enforce the attendance of witnesses and they lack direct legal mechanisms to impose sanctions in case of refusals to cooperate. Self-evidently, however, committees of inquiry can exert political pressure on those authorities and persons refusing to cooperate. Furthermore, the Parliament can bring an action under Article 265 TFEU before the Court of Justice of the European Union to defend its interests. Section 2.4.4.5 discusses in greater detail the sanctions at the disposal of the European Parliament in the event of a refusal to cooperate in the course of an inquiry.

\section{(3) Other persons}

The third category of witnesses is the residual category. On the basis of Article 3 (8) IIA committees of inquiry may request 'any other person' to give evidence before it 'insofar as is necessary for its duties'. Committees of inquiry may want to invite persons who fall outside the first two categories. A wide variety of persons could be considered in this regard, such as persons with specific academic or practical knowledge, former politicians and former officials/servants. The type of witness a committee of inquiry would like to hear depends on the inquiry at hand. In the event of an inquiry into a competition issue, it is conceivable that the committee of inquiry would wish to hear high officials from the enterprises involved, whereas in the event of an inquiry into an environmental issue it would perhaps be useful to invite people working for Greenpeace.

On the basis of Article 3 (8) IIA, committees of inquiry may request such 'other persons' to appear. In no sense can they summon them. Besides, such a right of summons vis-à-vis this category of persons would not only be quite farreaching, it would also be questionable from a legal perspective. Interinstitutional agreements can only produce legal effect inter partes ${ }^{148}$, i.e. in the relations between the three institutions which agreed on the Interinstitutional Agreement, namely the Parliament, the Council (including the Member States represented therein), and the Commission. The Interinstitutional Agreement consequently cannot bind third parties. The Lisbon Treaty brings change in this respect, by requiring in Article 226 TFEU that future details governing the exercise of the right of inquiry be laid down in

${ }^{148}$ De Witte (2008), p. 102. 
a regulation (which produces legal effects erga omnes). However, as long as the Parliament, Council and Commission do not reach an agreement on such a regulation, the current interinstitutional agreement, which applies inter partes, remains in force. ${ }^{149}$

\subsubsection{Legal position of witnesses}

The legal position of witnesses is in general terms provided for in Rule 185 (7) of the Rules of Procedure. This internal rule stipulates:

'Persons called to give evidence before a committee of inquiry may claim the rights they may enjoy when acting as witnesses before a tribunal in their country of origin. They must be informed of these rights before they make a statement to the committee'.

For several reasons, this is a remarkable provision. Firstly, because it assigns committees of inquiry the task of informing witnesses of the rights they would enjoy as a witness before a national court (i.e. not before a national committee of inquiry), even though these rights may not be applicable in the course of national parliamentary inquiries. ${ }^{150}$ Perhaps it would have been more logical to draw a parallel with national parliamentary inquiries rather than national judicial proceedings. Secondly, it is remarkable that the Parliament binds itself by this provision even though it was under no legal duty to do so. As a result, the Parliament has saddled its committees of inquiry with the time-consuming task of identifying the rights of witnesses before national courts. John Tomlinson, chairman of the committee of inquiry into the Community Transit regime, criticized the provision for being unworkable. He noted that even in the same Member State there was no single set of rules that could be applied. ${ }^{151}$ Rule 185 (7) Rules of Procedure may further undermine the right of inquiry as it is plausible that a duty to inform witnesses of their rights may encourage these witnesses to withhold relevant information which they would otherwise have provided to the inquiry committee. Thirdly, if one really wants to guarantee the rights of witnesses, the internal Rules of Procedure is not the appropriate framework, as Parliament may at any time unilaterally decide to remove or amend its internal provisions. From the perspective of legal protection of witnesses, it would be preferable to lay down the rights of witnesses in an interinstitutional agreement, or, as Article 226 TFEU currently prescribes, in a regulation. Considering the rather weak powers committees of inquiry have vis-à-vis witnesses, their legal protection is not

\footnotetext{
149 Section 2.6 addresses the European Parliament's proposals for such a regulation on its right of inquiry.

${ }_{150}$ In 2006, the European Court of Human Rights held that the hearing of witnesses in the course of a parliamentary inquiry by the Dutch Tweede Kamer did not fall within the scope of Article 6 of the European Convention of Human Rights. As a consequence, the applicant could not invoke the right to remain silent and the right not to incriminate oneself. $C f$. ECHR (2006) Van Vondel v The Netherlands (appl. nr. 38258/03).

151 European Parliament (1997). Transit committee. Chairman's report on the working methods of the Committee of Inquiry into the Community Transit System (PE 220.696/rev., 21.2.1997), p. 8.
} 
urgently needed. However, it goes without saying that witnesses should be protected better if committees of inquiry were to gain stronger powers vis-à-vis witnesses in the future, such as a general right of summons or an obligation to testify under oath in public.

\section{Duty to give evidence}

The question arises as to what the rights and obligations of witnesses are when they appear before committees of inquiry. Section 2.4.4.1 has shown that two categories of witnesses are under no legal duty to appear before a committee of inquiry, i.e. witnesses of the first category ${ }^{152}$ (members of an institution or a body of the European Union or the government of a Member State) and witnesses of the third category (the residual category). Witnesses who are under no legal duty to appear before a committee of inquiry cannot be put under any legal obligations if they decide to give evidence on a voluntary basis. However, the duty of sincere cooperation ex Article 4 (3) EU Treaty implies that EU and Member State authorities are under an obligation to adopt a cooperative attitude towards committees of inquiry, which means that these authorities must refrain from measures which jeopardize the work of committees of inquiry in any case. Deliberate lies and the provision of misleading information represent blatant violations of the duty of sincere cooperation. The same is true if relevant information is deliberately withheld from committees of inquiry without reasonable justification.

As a matter of course, the duty of sincere cooperation applies a fortiori to those witnesses who are under a duty to appear before a committee of inquiry. A legal duty to appear would, after all, be pointless if it were not combined with a duty to give evidence. The duty to give evidence is, however, restricted. Concerning witnesses of the second category ('officials and servants'), the last part of Article 3 (3) IIA stipulates: 'the officials or servants in question shall speak on behalf of and as instructed by their Governments or institutions. They shall continue to be bound by the obligations arising from the rules to which they are subject.'

These witnesses thus testify in their capacity as officials or servants, i.e. not in their capacity as private persons. Article 3 (3) IIA requires committees of inquiry to provide reasons for any request to hear an official or servant. On the basis of such a reasoned request, a government or institution can instruct the official or servant in question on the scope of the authorization to speak on its behalf. Inquiry committees must respect the refusal of a witness to give evidence if doing so would go beyond the scope of the instruction as issued to them by their superiors. ${ }^{153}$ Article 3 (3) IIA further implies that officials and servants continue to be bound by the obligations arising from the rules to which they are subject. Such an obligation is for example the duty of professional secrecy to which officials and servants are subject. At the EU level, a general duty of professional secrecy is provided for in Article 339 TFEU: 'The members of the institutions of the Union, the members of committees, and

\footnotetext{
${ }_{152}$ Except for Commissioners, who are compelled to appear pursuant to Article 230 TFEU. $C f$. Section 2.4.4.1.

${ }^{153}$ Höpfner (2004), p. 203.
} 
the officials and other servants of the Union shall be required, even after their duties have ceased, not to disclose information of the kind covered by the obligation of professional secrecy, in particular information about undertakings, their business relations or their cost components'. More specific rules on the forwarding of confidential information from the Commission to the Parliament are laid down in a framework agreement between the two institutions. ${ }^{154}$ The Rules of Procedure of the European Parliament further include arrangements for the treatment of confidential and sensitive information by the Parliament. ${ }^{155}$

Arrangements concerning the professional secrecy of national officials and servants can be found in national legislation. It follows from Article 3 (3) IIA that, in the event of a conflict between the duty of professional secrecy and the duty to give evidence, the former duty takes precedence over the latter.

\section{Oath}

There are many reasons for requiring witnesses to testify under oath. Because of the threat of punishments for perjury, evidence given under oath is generally considered more reliable. It is further likely that witnesses, when giving testimony under oath, feel additional pressure to speak the truth. Although the initial proposal of the European Parliament included an arrangement for witnesses to take an oath before giving evidence ${ }^{156}$, the current legal framework does not provide for such an arrangement. It is, however, questionable whether an obligation to take an oath would make sense in the absence of a mechanism to punish perjury.

\section{Public nature of the hearings}

Article 2 (2) IIA lays down rules for the hearings organized by committees of inquiry of the European Parliament. The last sentences of the paragraph stipulate: 'Hearings and testimony shall take place in public. Proceedings shall take place in camera if requested by one quarter of the members of the committee of inquiry, or by the Community or national authorities, or where the temporary committee of inquiry is considering secret information. Witnesses and experts shall have the right to make a statement or provide testimony in camera'. The last sentence of Article 2 (2) IIA is remarkable, since it implies a unilateral right of witnesses to choose to give testimony in camera. This provision is perhaps less remarkable in respect to witnesses who are under no legal duty to testify before a committee of inquiry, since these witnesses already are in the strong position of being able to decide whether to give evidence at all. It would, however, be appropriate to give committees of

\footnotetext{
${ }^{154} \mathrm{Cf}$. Annex 2 of the Framework Agreement on relations between the European Parliament and the European Commission (OJ L 304, 20.11.2010, pp. 47-62).

${ }_{155} \mathrm{Cf}$. Annex VIII of the Rules of Procedure of the European Parliament.

156 Article 5 (5) EP proposal reads: 'The committee of inquiry shall decide whether witnesses or experts shall be required to take the oath or give an undertaking. At the request of one quarter of its members, the committee of inquiry shall dispense them from this obligation'. $C f$. European Parliament (1992). Proposal of the European Parliament on parliamentary committees of inquiry (A3-0302/02, OJ C 21, 25.1.92, pp. 147-151), p. 150.
} 
inquiry, not the witnesses, the final say over the organization of inquiry proceedings.

\section{Legal assistance}

The arrangements on the right of inquiry of the European Parliament are silent on the issue of legal assistance before a committee of inquiry. This is a particularly relevant issue for witnesses who can be put under a legal duty to testify. It is arguable that these witnesses should have legal assistance when giving oral evidence. Legal assistance not only serves to protect the witnesses in question, but, moreover, is in the interest of the authorities being represented by these witnesses. One of the tasks of a legal advisor would be to prevent the witness from disclosing information that falls under a duty of professional secrecy. The only legal provision that could be relevant for the issue of legal assistance is Rule 185 (7) Rules of Procedure of the European Parliament, which stipulates that witnesses before a committee of inquiry "may claim the rights they would enjoy if acting as witness before a tribunal in their country of origin'. Ascertaining the various rights witnesses have before tribunals in the different Member States falls outside the scope of this book. However, it is reasonable to assume that most Member States allow legal assistance in such situations, which implies that officials and servants can be legally assisted when giving evidence before committees of inquiry of the European Parliament too. It is certainly advisable, however, that an explicit provision on legal assistance be included in any revision of the provisions governing the exercise of the right of inquiry.

\subsubsection{Access to documents}

In addition to gathering oral evidence by questioning witnesses, committees of inquiry may want to collect written evidence. The right of access to documents is provided for in Article 3 (4) IIA, which reads: 'the authorities of the Member States and the institutions or bodies of the European Communities shall provide a temporary committee of inquiry, where it so requests or on their own initiative, with the documents necessary for the performance of its duties, save where prevented from doing so by reasons of secrecy or public or national security arising out of national or Community legislation or rules'.

The authorities under investigation are thus under a legal duty ('shall') to provide a committee of inquiry with all documents necessary for an inquiry. Article 3 (4) IIA and Article 3 (5) IIA provide for exceptions, which are discussed separately below.

\section{Article 3 (4) Interinstitutional Agreement}

The general duty to forward documents to a committee of inquiry upon the request of the latter is firstly restricted by the last part of Article 3 (4) IIA, which reads: 'save where prevented from doing so by reasons of secrecy or public or national security arising out of national or Community legislation or rules'. 
This restriction is almost identical to the one discussed above with respect to the committee's right to require officials and servants to appear before it. ${ }^{157}$ The question arises which rules on secrecy and security are relevant in this respect. Concerning EU authorities, Regulation 1049/2001 is of importance. This regulation stipulates that EU institutions shall refuse access to documents where disclosure would undermine the protection of the public interest in terms of 'public security', 'defence and military matters', 'international relations', and 'the financial, monetary or economic policy of the Community or a Member State'. ${ }^{158}$ EU institutions must also refuse access to documents where disclosure would undermine the protection of an individual's privacy or integrity. ${ }^{159}$

The Interinstitutional Agreement contains no procedure for when a committee requests sensitive documents. The Statute of the European Ombudsman, which does include such a procedure, could serve as an example in such situations. The third and fourth paragraph of Article 3 (2) of this Statute stipulate: 'The institutions or bodies supplying classified information or documents $[\ldots]$ shall inform the Ombudsman of such classification. [...] the Ombudsman shall have agreed in advance with the institution or body concerned the conditions for treatment of classified information or documents and other information covered by the obligation of professional secrecy.' ${ }^{160}$ It is advisable that such a provision be included in the event of a revision of the provisions governing the exercise of the right of inquiry.

Article 3 (4) IIA further includes an exception to the general rule that Member States shall provide committees of inquiry with relevant documents. Member State authorities may decide to refuse a request for documents for 'reasons of secrecy or public or national security arising out of national [...] legislation or rules'. Article 3 (5) IIA provides a procedure for the event that a committee requests sensitive documents originating in a Member State: 'an obstacle arising from reasons of secrecy, public or national security or the provisions referred to in the first subparagraph shall be notified to the European Parliament by a representative authorized to commit the Government of the Member State concerned or the institution'.

\section{Article 3 (5) Interinstitutional Agreement}

Article 3 (5) IIA contains an additional restriction on the right of access to documents that is identical to the second restriction on the right to call

\footnotetext{
${ }_{157} \mathrm{Cf}$. Section 2.4.4.1.

${ }_{158} C f$. Article 4 (1a) of Regulation (EC) No 1049/2001 of the European Parliament and of the Council of 30 May 2001 concerning public access to European Parliament, Council and Commission documents (OJ L 145, 31.5.2001, pp. 43-48).

${ }_{159} C f$. Article 4 (1b) of Regulation (EC) No 1049/2001 of the European Parliament and of the Council of 30 May 2001 concerning public access to European Parliament, Council and Commission documents (OJ L 145, 31.5.2001, pp. 43-48).

${ }^{160} \mathrm{Cf}$. 'Decision of the European Parliament on the regulations and general conditions governing the performance of the Ombudsman's duties'. The European Ombudsman Statute was adopted by the Parliament on 9 March 1994 (OJ L 113, 4.5.1994, p. 15) and amended by its decisions of 14 March 2002 (OJ L 92, 9.4.2002, p. 13) and 18 June 2008 (OJ L 189, 17.7.2008, p. 25).
} 
witnesses. ${ }^{161}$ The provision stipulates that the right of access to documents 'shall be without prejudice to any other provisions of the Member States which prohibit [...] documents from being forwarded'. This restriction extends the exception in Article 3 (4) IIA. Whereas the latter provision can only be invoked for a particular reason, namely 'secrecy or public or national security', Article 3 (5) IIA does not prescribe such a requirement. It merely includes the formal criterion that if there is a national provision (with whatever purpose) which prohibits certain documents being forwarded to a committee of inquiry, than this national provision takes precedence over the general duty of Article 3 (4) IIA.

It goes without saying that the duty of sincere cooperation ex Article 4 (3) EU Treaty plays a role in the context of access to documents. One could, for example, be inclined to conclude that - in view of the wording of Article 3 (5) IIA - it is possible for a national legislator to adopt a national law placing a blanket prohibition on the forwarding of documents to a committee of inquiry of the European Parliament. Obviously this would run counter to the duty of sincere cooperation. Thus, any refusal to forward documents to a committee of inquiry must be assessed not only in the light of the specific legal provisions, but also in the light of the general duty of sincere cooperation.

\subsubsection{Fact-finding visits}

Committees of inquiry generally rely on oral and written evidence in their endeavour to gain an understanding of the issue under investigation. In some cases, however, it can be useful for committee members to make visits in person in order to witness things with their own eyes. Committees of inquiry have no formal powers related to such fact-finding visits, such as a right to enter premises. In contrast with, for example, committees of inquiry of the Dutch Tweede Kamer, which can enter inter alia ministry buildings ${ }^{162}$, committees of inquiry of the European Parliament do not have a right to enter - let's say the Commission's Berlaymont building in Brussels in order to look for specific documents. The Interinstitutional Agreement does not even mention on-thespot visits as a means of gathering evidence. Rule 185 (5) of the Rules of Procedure merely provides a general arrangement for committees of the European Parliament: 'any committee may, with the agreement of Parliament's Bureau, instruct one or more of its members to undertake a study or factfinding mission'.

Practice shows that committees of inquiry of the European Parliament regularly make use of fact-finding visits. During the inquiry into BSE, the committee of inquiry carried out a visit to the UK in order to obtain an on-thespot picture of the veterinary measures being taken to combat BSE. The committee also held talks with representatives of the national and local authorities. ${ }^{163}$ Similar fact-finding visits were conducted for the inquiries into

\footnotetext{
${ }^{161} \mathrm{Cf}$. Section 2.4.4.1.

${ }^{162} C f$. Article 7 of the Dutch Parliamentary Inquiry Act 2008.

${ }^{163} \mathrm{Cf}$. Section 2.5.2.3.
} 
the Community Transit regime ${ }^{164}$ and the Equitable Life Assurance Society crisis. ${ }^{165}$

\subsubsection{Sanctions}

Committees of inquiry and authorities under investigation are subject to the legal provisions governing the right of inquiry of the European Parliament. As discussed above, both Member States and EU authorities have a formal duty to cooperate with committees of inquiry. In general, legal obligations assume significance if they are linked to some form of sanction in the event of the obligation not being met. This raises the question of which sanctions committees of inquiry can impose should there be an unjustified refusal to cooperate with an inquiry.committee

In contrast with the situation in some Member States, where committees of inquiry can autonomously impose fines in the event of an unjustified refusal to cooperate ${ }^{166}$, committees of inquiry of the European Parliament lack such direct sanction mechanisms. It does not follow, however, that infringements of the rights of a committee of inquiry automatically remain without consequences. Rule 185 (6) of the Rules of Procedure stipulates that a committee of inquiry which considers that its rights have been infringed shall propose that the President of the Parliament take appropriate measures. The range of judicial and political measures which the Parliament can take in response to alleged infringements of its rights is discussed separately below.

\section{Judicial sanctions}

If an inquiry committee considers its rights to have been infringed, the Parliament can turn to the Court of Justice of the European Union to defend its interests. On the basis of Article 265 TFEU the Parliament may bring an action against a wide range of executive actors for failure to act. Whereas before Lisbon (under Article 232 EC Treaty) the European Parliament could only bring an action for failure to act against the Council, the Commission and the ECB, this action can now be brought against a wider range of EU executive actors. The Lisbon Treaty has added the following stipulation to Article 265 TFEU: 'this Article shall apply, under the same conditions, to bodies, offices and agencies of the Union which fail to act'.

The proceedings outlined in Article 265 TFEU are intended to establish whether an institution, body, office or agency of the Union has infringed Union law by failing to act. This could for example be a refusal to designate an official to give evidence or a refusal to submit documents to a committee of inquiry. Article 265 TFEU prescribes that the 'action shall be admissible only if the institution, body, office or agency concerned has first been called upon to act'. Once such a request has been made, the institution, body, office or agency has two months within which to define its position. If it refrains from doing so, the

\footnotetext{
${ }^{164}$ Cf. Section 2.5.1.2.

${ }^{165}$ Cf. Section 2.5.3.2.

166 This is inter alia the case in Germany, where committees of inquiry may fine witnesses in case of a groundless refusal to appear and/or to give evidence before a committee of inquiry (Cf. Paragraphs 21 and 27 of the German Parliamentary Inquiry Act).
} 
applicant (in this case the European Parliament) has a further two months within which to bring an action under Article 265 TFEU. ${ }^{167}$ The Court of Justice might then establish that an infringement has taken place. If, however, the inquiry has already come to an end by the time this decision is made, it will be too late to be of any direct use to the committee of inquiry.

As Member States are not listed in Article 265 TFEU, it follows that the Parliament cannot bring a direct action against them. The Parliament can only request that the Commission initiate infringement proceedings against a Member State that has failed to fulfil its obligations under the Treaty ( $c f$. Article 258 TFEU). ${ }^{168}$ If the Commission considers that a violation of Union law has occurred, it shall firstly give the Member State concerned the opportunity to explain its position. It is possible that the matter be resolved at this stage. If not, the Member State will be formally notified of the specific alleged infringement by means of a letter from the Commission. If the Member State still does not react satisfactorily to this formal notification, the Commission may issue a 'reasoned opinion' to the Member State. In this reasoned opinion, the Commission sets out clearly the grounds on which the alleged infringement rests. The reasoned opinion marks the beginning of the time period within which the Member State must comply in order to avoid the final stage: referral to the CJEU. The Commission enjoys considerable discretion to decide whether or not to refer a matter to the CJEU. ${ }^{169}$ The European Parliament's committee of inquiry into the BSE crisis experienced this in 1997, when the Commission refused a request made by the Parliament to institute infringement proceedings against the United Kingdom on account of the refusal of a British minister to appear before the inquiry committee. The Commission stated (rightly) that such recourse would have no chance of success, since members of national governments cannot be obliged to appear before a committee of inquiry of the European Parliament. Section 2.5.2.3 addresses this issue in more detail.

It is conceivable that Member States are inclined to cooperate with committees of inquiry in order to avoid referral to the CJEU. Calling upon the Commission to initiate infringement proceedings - or the mere threat of doing so - thus might prove helpful for a committee of inquiry to enforce its rights. However, if a Member State decides to stick to its refusal to cooperate with an inquiry until the CJEU gives its judgment, the damage to the inquiry may be irreparable, as the usual length of time required for infringement proceedings to be completed means the inquiry will probably have already come to an end. Therefore, the Court of Justice should be asked to prescribe an interim measure in such cases. ${ }^{170}$

\section{Political sanctions}

The Parliament can furthermore react to infringements of its rights by taking political measures. The right to put questions to executive actors - especially

\footnotetext{
${ }_{167}$ Cf. Craig/De Búrca (2011), p. 514.

${ }^{168}$ For a description of the several stages of the infringement procedure see: Ibid. p. 413.

$169 \mathrm{Ibid}$. p. 415 and further.

170 Article 279 TFEU stipulates: 'The Court of Justice of the European Union may in any cases before it prescribe any necessary interim measures'.
} 
the Commission and the Council - presents an opportunity to obtain an explanation for any reluctance to cooperate in the course of an inquiry. Answers to such questions may be followed by the adoption of a resolution, in which the Parliament can express its opinion - e.g. its discontent with the behaviour of executive actors - or its wishes pertaining to a specific matter.

The strongest instrument in the armoury of the European Parliament vis-à-vis the Commission, at least in theory, is the motion of censure which it can table by virtue of Article 234 TFEU. If the motion of censure is adopted by a twothirds majority, representing a majority of the Members of the European Parliament, the Commission shall resign as a body. Although formally the motion of censure can only be used to dismiss the entire Commission (i.e. not a single Commissioner), the collective accountability of the Commission is gradually evolving into a structure of individual accountability of Commissioners. ${ }^{171}$ Before becoming the new Commission President in 1999, Romano Prodi stated that he would not hesitate to ask for the resignation of an individual Commissioner, should this prove necessary. All Commissioners accepted their portfolios on this understanding. ${ }^{172}$ Article 217 EC Treaty was amended accordingly with the Treaty of Nice. The fourth paragraph of this provision stipulated: 'a Member of the Commission shall resign if the President so requests, after obtaining the approval of the College'. The Treaty of Lisbon amended this provision again. Article 17 (6) EU Treaty reads: 'A member of the Commission shall resign if the President so requests'. The elimination of the last part of the former Article 217 (4) EC Treaty ('after obtaining approval of the College') underlines the reinforced position of the President of the European Commission. The power of the Commission President to dismiss individual Commissioners paves the way for the (indirect) individual accountability of Commissioners. There is nothing to prevent the Parliament from adopting a resolution criticizing an individual Commissioner and requesting the Commission President to make use of his or her discretion under Article 17 (6) EU Treaty. It may be assumed that a Commission President would generally prefer to sack a single Commissioner rather than take the risk of facing a motion of censure against the Commission as a whole. ${ }^{173}$ Admittedly, it is quite inconceivable that the Parliament would adopt a motion of censure in response to the Commission refusing to cooperate in the course of an inquiry. However, the mere threat of tabling such a motion might urge the Commission to adopt a more cooperative attitude.

The European Parliament can furthermore use the public character of an inquiry to exert pressure on the Member States, EU authorities and persons involved to secure their cooperation throughout the entire inquiry. 'Namingand-shaming', as well as the other political pressure mechanisms discussed above, need not be reserved for when the specific rights of a committee of inquiry are infringed upon. John Tomlinson, the chairman of the committee of inquiry into the Community Transit regime, demonstrated aptly how a committee of inquiry can use naming-and-shaming tactics to get what it wants.

\footnotetext{
${ }_{171}$ Mehde (2009), p. 75; Verhey/Claes/Broeksteeg (2008), p. 310.

172 Craig (2000), p. 110; Clegg/Van Hulten (2004), p. 25.

173 Cf. Corbett/Jacobs/Shackleton (2011), p. 311.
} 
The repeated failure of several Member States to respond promptly to a request for information led chairman Tomlinson to call a press conference at which he listed the various countries that had failed to provide an answer. Michael Shackleton, who was head of the committee's secretariat, pointed out that this served to accelerate the return of information. ${ }^{174}$

\subsubsection{Legal protection in the course of inquiries}

It is beyond dispute that the predominant public nature of parliamentary inquiries can have far-reaching consequences for the authorities and persons involved. The following sections discuss whether the 'subjects of investigation' (cf. Section 2.4.3.2) can invoke legal protection against, firstly, the establishment of a committee of inquiry and, secondly, against an individual act by a committee of inquiry.

\subsubsection{Legal protection against the establishment of a committee of inquiry}

Legal protection against the establishment of a committee of inquiry is provided for by the action for annulment (ex Article $263 \mathrm{TFEU}$ ) which enable certain applicants to call on the CJEU to review the legality of a specific act. If the action is well-founded, the CJEU declares the act void ( $c f$. Article 264 TFEU).

Three criteria must be fulfilled for an action for annulment to be reviewed by the CJEU. Firstly, the action must be brought by an authorized applicant. There are three categories of applicant: (1) privileged applicants (Member States, the European Parliament, the Council, and the Commission), which can always challenge the legality of acts before the Court of Justice, (2) semiprivileged applicants (the Court of Auditors, the European Central Bank, and, since Lisbon, the Committee of the Regions), which may only defend their own prerogatives and, (3) non-privileged applicants (legal or natural persons), which may only institute proceedings against a decision addressed to that person or against a decision which is of direct and individual concern to the former. ${ }^{175}$ Secondly, an applicant must prove that a decision to establish a committee of inquiry is an act intended to produce legal effects vis-à-vis third parties. Parliamentary acts related only to the Parliament's internal organization thus cannot be challenged in an action for annulment. ${ }^{176}$ Acts of the Parliament which do produce or which are intended to produce legal effects with regard to third parties, however, do fall within the scope of Article 263 TFEU. ${ }^{177}$

\footnotetext{
174 Shackleton (1998), p. 128; Section 2.5.1. discusses the inquiry into the Community Transit system.

175 Chalmers (2006), pp. 416-436.

${ }_{176}$ Cf. Case C-78/85, Group of the European Right v European Parliament, para. 11; Case C68/90, Blot and Front national v European Parliament, para. 11; Case C-314/91, Weber v European Parliament, para. 9; Case T-17-00, Willi Rothley v European Parliament, para. 54.

177 Case C-314/91, Weber v European Parliament, para. 11; Joined cases T-222/99, T327/99 and T-329/99, Martinez and Others v European Parliament, para. 53); Willi Rothley v European Parliament, paras. 55-57.
} 
How should the parliamentary act by which a committee of inquiry is established be typified? Does it produce, or does it intend to produce legal effects vis-à-vis third parties? Before the entry into force of the Maastricht Treaty and the Interinstitutional Agreement, committees of inquiry were a purely internal phenomenon, established solely on the basis of the internal Rules of Procedure of the European Parliament and without additional powers at their disposal vis-à-vis third parties. ${ }^{178}$ For that reason, the ECJ declared an action for annulment of a decision to establish a committee of inquiry in 1986 to be inadmissible. ${ }^{179}$ However, the claim that setting up a committee of inquiry is a purely internal organizational matter is no longer valid. Present-day committees of inquiry are set up on the basis of a Treaty provision and they have at their disposal additional powers vis-à-vis third parties, such as the right to call witnesses and the right of access to documents. Today, a decision to establish a committee of inquiry thus goes beyond the internal organization of the Parliament by activating additional powers vis-à-vis third parties. Since committees of inquiry gain no additional rights vis-à-vis legal or natural persons, it follows that these non-privileged applicants cannot bring an action to have the legality of a decision to establish a committee of inquiry reviewed. However, other applicants under Article 263 TFEU may be successful in bringing the case before the CJEU. The third criterion is a time-limit of two months, within which the action must be brought (Article 263 TFEU).

Subsequently, in order for an admissible action to be successful, the applicant must prove that the establishment of a committee of inquiry is 'illegal' on one of the grounds stipulated in Article 263 TFEU. These grounds are: lack of competence, infringement of an essential procedural requirement, infringement of the Treaties or of any rule of law relating to their application, or misuse of powers. The third basis - infringement of the Treaties - appears to be the most relevant, as it is most conceivable that an applicant could claim that the Parliament intends to set up a committee of inquiry contrary to the conditions laid down in Article 226 TFEU. Some examples may illustrate this. The CJEU may be called upon to deliver a judgement on whether the inquiry is admissible in light of the sub judice rule, as formulated in Article 226 TFEU. ${ }^{180}$ Furthermore, applicants may claim that a committee of inquiry intends to investigate an issue which is purely national in nature. Before Lisbon, applicants could claim that a committee of inquiry intended to investigate a second or third-pillar issue. Wiersma, a former MEP, notes that the parliamentary investigation into Echelon was not conducted by a committee of inquiry but by a regular temporary committee due to the fear that a Member State would call on the ECJ claiming that the committee of inquiry would investigate matters beyond its scope. ${ }^{181}$ However, such an inquiry could have been admissible under the current Article 226 TFEU. committeeDecisive for whether an action contesting the establishment of a committee of inquiry is admissible or not is whether the establishment as such - i.e. not its possible

\footnotetext{
${ }_{178} \mathrm{Cf}$. Section 2.2.

179 Case C-78/85, Group of the European Right v European Parliament, para. 11.

180 Section 2.4.3.1. addresses the sub judice rule.

181 Wiersma (2004), p. 226.
} 
consequences - conforms with EU law. Thus, a decision to set up a committee of inquiry cannot be declared void merely due to a fear that a committee of inquiry will act 'illegally' in the future.

Actions brought before the CJEU do not have a suspensory effect. However, Article 278 TFEU stipulates that the CJEU may suspend the application of the contested act, if it considers that circumstances so require. Hence, in view of the urgency, an applicant who wishes to prevent the Parliament from starting an inquiry should seek such an interim measure.

\subsubsection{Legal protection against acts of committees of inquiry}

The CJEU may also be called upon in the course of an inquiry to review the legality of an act of an inquiry committee. Again, the action for annulment ex Article 263 TFEU forms the legal basis for this. As discussed above, Article 263 TFEU requires that an authorized applicant prove that the act is intended to produce legal effects vis-à-vis third parties and that the act is 'illegal' on one of the grounds stipulated in Article 263 TFEU.

Section 2.4.4 shows that committees of inquiry can produce legal effects vis-àvis third parties in several ways. Firstly, committees of inquiry can oblige Member States and EU institutions and bodies to designate an official or servant to appear before them. These officials and servants are under a duty to give evidence to the inquiry committee. Secondly, members of the Commission are both under a legal duty to appear before committees of inquiry and to answer questions put to them. Thirdly, Member States and EU institutions and bodies are under a legal duty to send documents to committees of inquiry, upon request of the latter.

The question subsequently arises how committees of inquiry can act illegally when asserting their rights under the Interinstitutional Agreement. In general, it can be said that committees of inquiry act illegally if they use their powers for purposes other than those for which they were granted. The purpose of committees of inquiry is to fulfil their mandate formulated by the European Parliament. It follows that a committee of inquiry cannot place a Member State under a legal duty to send it documents which fall outside the mandate of the inquiry committee. Article 3 (1) IIA further restricts the scope of the powers of committees of inquiry by stipulating that committees of inquiry shall carry out the inquiries 'necessary to verify alleged contraventions or maladministration in the implementation of Community law'. The use of inquiry powers thus must not only fall within the committee's mandate but also be necessary in order to fulfil the mandate. Moreover, committees of inquiry act illegally if they disregard the restrictions provided for in Article 3 (3) IIA ('grounds of secrecy or public or national security'), Article 3 (4) IIA ('reasons of secrecy or public or national security'), and Article 3 (5) IIA ('other provisions of the Member States which prohibit officials from appearing or documents from being forwarded').

Admittedly, the reasoning on the possibilities of challenging the exercise of a committee of inquiry's rights under the Interinstitutional Agreement is highly theoretical. As committees of inquiry lack mechanisms to enforce their powers, it may be assumed that authorities and persons called upon to cooperate in the 
course of the inquiry simply prefer to ignore such a request over making a time-consuming challenge before the CJEU.

\subsubsection{Inquiry outcomes and follow-up}

Committees of inquiry cease to exist when they submit their report to the plenary. ${ }^{182}$ Single members of a committee of inquiry can deliver a minority opinion in the report. ${ }^{183}$ As a rule, the report is debated in plenary at the partsession following its submission. ${ }^{184}$ This debate can be used to sound out the Commission, generally represented by the responsible Commissioner, and the Council, generally represented by its President-in-Office. ${ }^{185}$ A committee of inquiry's report, which usually has already been amended in committee, may be further amended in plenary. The final report generally includes recommendations addressed to EU authorities and/or to Member States. As it is important that conclusions and recommendations are actually dealt with after the inquiry has come to an end, Rule 185 (11) of the Parliament's Rules of Procedure mandates the President of Parliament to instruct the (standing) committee responsible to monitor the action taken on the results of the work of the committee of inquiry and, if appropriate, to report thereon.

The Parliament may also want to impose sanctions on specific executive actors if committees of inquiry have revealed abuses which can be attributed to them. It should be noted that the word 'sanction' has a rather formal and legal connotation. It is however not restricted to formal sanctions, such as disciplinary measures or the adoption of a motion of censure. The importance of informal or implicit sanctions, such as having to account for one's actions in front of television cameras or the damage caused to a person's public image and career as a result of negative publicity, cannot be overlooked. ${ }^{186}$ In practice, the informal mechanism of penalizing executive misbehaviour by publicly disapproving of the behaviour of executive actors may be an effective means of securing redress or reparation. This sanction mechanism can be used at any time and against any executive actor. This differs from the other sanctioning powers of the European Parliament, which can only be used vis-à-vis some (or only one) executive actor. The array of sanctioning powers at the disposal of the Parliament vis-à-vis specific executive actors is discussed below.

\section{Sanctioning powers vis-à-vis the Commission}

The power to impose sanctions is particularly strong with regard to the Commission. Section 2.4.4.5 describes the power to censure the Commission under Article 234 TFEU. The fact that a vote of no confidence has never been passed does not automatically mean that the power to censure is weak. The

${ }^{182} C f$. Article 226 TFEU: 'The Temporary Committee of Inquiry shall cease to exist on the submission of its report'.

${ }^{183}$ Cf. Rule 185 (10) Rules of Procedure.

${ }^{184}$ Cf. Rule 185 (10) Rules of Procedure.

${ }^{185} \mathrm{Cf}$. Article 230 TFEU and Article 26 of the Rules of Procedure of the Council (OJ L 285, 16.10.2006, pp. 47-71).

${ }^{186}$ Bovens mentions the example of Edith Cresson, the former Commissioner who became the main target of criticism in the fraud allegations that led to the resignation of the Santer Commission in 1999; $C f$. Bovens (2007), p. 452. 
opposite seems to be true. The threat of censure is a powerful weapon which the Parliament can use to put the Commission under pressure. Two historical events may illustrate this.

In 1997, a committee of inquiry adopted a report which was critical about the way the Commission managed the BSE issue. The plenary approved the report and it adopted a resolution calling on the Commission to take urgent and effective action to follow up on the recommendations in the report and to implement the measures formulated therein without delay. In order to ensure that the recommendations were dealt with in practice, the Parliament threatened to table a motion of censure against the Commission should the Commission not show improvements within six months. This conditional threat served to ensure that the Commission indeed followed up on most of the recommendations issued to it by the Parliament. ${ }^{187}$

In 1999, the findings of a Committee of Independent Experts, which was established to investigate claims of fraud, mismanagement and nepotism within the European Commission, resulted in strong support for a motion of censure. ${ }^{188}$ The Santer Commission, however, resigned in advance of the motion that almost certainly would have been passed. ${ }^{189}$ Although adopting a motion of censure remains a nuclear option, a strategic use of this power enables the Parliament to wield control over the Commission. If Parliament deems that one or more individual Commissioners, rather than the Commission as a whole, should be removed from office, it can file a request to the Commission President to make use of his discretion under Article 17 (6) EU Treaty to urge individual Commissioners to resign.

\section{Sanctioning powers vis-à-vis the Council and the European Council}

The Parliament has a rather weak position when it comes to imposing sanctions on the Council and the European Council. In the absence of direct sanctioning powers, the Parliament can seek soft and/or indirect ways to achieve its aims. The Parliament may, for example, invite the President of the European Council and the President-in-office of the Council to give a reaction to the findings of a committee of inquiry in public. 'National' members of the Council and the European Council are in the first place accountable to their respective national parliaments ( $c f$. Article 10 (2) TEU). The Parliament can try to hold them to account indirectly by passing on inquiry results to national parliaments, which can then use their powers to hold their members of government to account at the national level.

\section{Sanctioning powers vis-à-vis Member States}

The Parliament's powers to impose sanctions on Member States are likewise limited. In addition to informing national parliaments of inquiry results, the Parliament may request the Commission to bring proceedings under Article 258 and 260 TFEU against Member States that have failed to fulfil their

\footnotetext{
${ }_{187}$ Section 2.5.2 discusses the parliamentary inquiry into the handling of the BSE crisis.

${ }^{188}$ Cf. Committee of Independent Experts (1999).

189 Cf. Weatherill/Beaumont (1999), p. 1061; Editorial Comment, Common Market Law Review (1999), p. 270; Nugent (2001), pp. 192-193; Corbett/Jacobs/Shackleton (2011), p. 310. For further reading on the events at the time; $C f$. Tomkins (1999).
} 
Treaty obligations. However, the Commission enjoys broad discretion to decide whether or not to refer a matter to the Court of Justice.

\section{Sanctioning powers vis-à-vis European agencies}

The Parliament lacks explicit powers to impose sanctions on European agencies. However, the European Parliament has the ultimate power of discharge over the expenditure of most EU agencies. ${ }^{190}$ Section 4.4.3.4 shows that the Parliament actually uses the discharge procedure to impose sanctions on agencies. In its capacity as a budgetary authority (together with the Council), the Parliament can further wield the 'power of the purse' by cutting agencies' budgets (or merely threatening to do so). In its capacity as a legislative authority (again with the Council), the Parliament can also try to pass secondary legislation to restructure agencies, to change their powers and tasks, or even to abolish them.

\subsection{The right of inquiry in practice: inquiries since 1993}

Although the European Parliament advocated strong powers for committees of inquiry after the entry into force of the Maastricht Treaty, it ultimately concluded an interinstitutional agreement which rather reflected the Council's desires. Section 2.4 shows that the 1995 Interinstitutional Agreement, which has not been amended to date, assigns only limited powers to committees of inquiry of the European Parliament. This section analyzes how committees of inquiry have dealt with their relatively limited formal position.

Since the formal recognition of its right of inquiry in 1993, the European Parliament has established three temporary committees of inquiry to investigate contraventions or maladministration in the implementation of Union law (before Lisbon: Community law). After the formalization of this right in the EC Treaty, it seems the Parliament could hardly wait to make use of it. Although the negotiations on the interinstitutional agreement caused some delay, it took little time for the first committee of inquiry to be established. Whereas in 1995 a minority proposal to establish a committee of inquiry to investigate the case of French nuclear tests in the Pacific did not win majority support ${ }^{191}$, in December of that same year a majority decided to set up a committee of inquiry to investigate alleged abuses in the Community Transit system. To date, two further parliamentary inquiries have been conducted. In 1996, shortly after the first committee of inquiry had been established, the Parliament set up a committee of inquiry to investigate the handling of the BSE crisis. After this ambitious start (two inquiries in the space of two years) it took a decade before the Parliament established its third committee of inquiry, into the crisis of the Equitable Life Assurance Society, in 2006. The three inquiries are discussed separately below.

\footnotetext{
190 Cf. Article 185 (2) Council Regulation 1605/2002 (OJ L 248, 16.09.2002, p. 1) as last amended by Council Regulation 1995/2006 (OJ L 390, 30.12.2006, p. 1): 'Discharge for the implementation of the budgets of the bodies referred to in paragraph 1 (EU agencies, CNS), shall be given by the European Parliament on the recommendation of the Council'.

191 Shackleton (1998), p. 117; Wiersma (2004), p. 227.
} 


\subsubsection{Inquiry into the Community Transit System}

\subsubsection{Subject, establishment and duration of the inquiry}

On the basis of a proposal by the Conference of Presidents ${ }^{192}$, the Parliament decided at its plenary session in December 1995 to set up a temporary committee of inquiry to examine alleged contraventions or maladministration in the Community Transit System. ${ }^{193}$

\section{Background information on the inquiry subject}

The Community Transit System was created to permit goods entering the European Community to defer tax payment until the goods either exited the Community or reached the country of destination. The immediate reason for the inquiry was a growing awareness that the Community Transit System was subject to a worrying level of fraud, in large part due to the ease with which such fraud could be perpetrated. International criminal organizations had exploited weaknesses in Transit procedures to evade government surveillance of considerable quantities of particularly high-tax products, such as cigarettes and alcohol. ${ }^{194}$ These concerns were confirmed in March 1995, when the Commission published a document entitled 'Fraud in the Transit Procedure, Solutions Foreseen and Perspectives for the Future'. ${ }^{195}$ The Commission revealed serious fraud in the Transit procedures, leading to the loss of several billion ECU (the precursor of the Euro). Similar concerns were also expressed by the Court of Auditors in its 1994 Annual Report, which was published in November $1995^{196}$, and by the Council in its November 1995 resolution on the computerization of the Transit System. ${ }^{197}$ The Parliament, however, noted that the reports provided by the Commission and the Court of Auditors did not specify the exact way the fraud was taking place, the increase in shortcomings and cases of maladministration, or even breaches of the relevant provisions of Community law, over the years. ${ }^{198}$ The Parliament therefore decided to mandate a committee of inquiry to investigate the issue.

\section{Transit committee}

The first committee of inquiry set up after the formalization of the right of inquiry - hereafter referred to as the Transit committee - was composed of 17

192 The Conference of Presidents consists of the President of Parliament and the chairmen of the political groups, who may arrange to be represented by a member of their group. The Conference of Presidents takes decisions on the organization of Parliament's work. $C f$. Rule 23 and 24 of the Rules of Procedure of the European Parliament.

193 This decision was published in the Official Journal of the European Communities on 12 January 1996 (OJ C 7, 12.1.1996, p. 1).

${ }_{194}$ European Parliament (1997). Transit committee. Report on the Community Transit System (Volume I, A4-0053/97, 20.2.1997), p. 19.

${ }_{195}$ European Commission (1995). Fraud in the Transit Procedure, Solutions Foreseen and Perspectives for the Future (COM/95/108, 29.03.1995).

196 European Court of Auditors (1995). Annual Report for 1994 (OJ C 303, 14.11.1995).

197 OJ C 327, 7.12.1995, p. 2.

198 Decision of the European Parliament to set up a temporary committee of inquiry to examine alleged contraventions or maladministration in the Community Transit System (OJ C 7, 12.1.1996), p. 3. 
full members and 17 substitutes. The Transit committee started its work in January 1996 under the chairmanship of the British MEP John Tomlinson (PES). The rapporteur was the British MEP Edward Kellett-Bowman (EPP). The committee's mandate was to investigate in particular the reasons for the crisis in the Transit System, the shortcomings and loopholes in the procedures, the measures taken to improve the procedures, the additional measures to be taken forthwith, and the measures taken or to be taken to recover the sums lost and to penalize those responsible. ${ }^{199}$

In February 1997, one month after the prescribed time limit of twelve months had been extended by three months, the Transit committee presented its final report. ${ }^{200}$

\subsubsection{Inquiry proceedings}

The committee of inquiry conducted its work between 16 January 1996 and 19 February 1997. At the outset of its work, the committee published a call for evidence in the Official Journal and on the internet, encouraging persons with relevant information to send in written contributions. ${ }^{201}$ Following this call for evidence, the committee received 41 specific written contributions. ${ }^{202}$ Some formed the basis for the hearing of witnesses whereas others were retained as written evidence only. ${ }^{203}$

37 meetings were held in the course of the inquiry at the rate of roughly three per month. The committee held three kinds of meeting: (I) interrogative meetings at which witnesses were questioned, (II) information meetings designed to enable the committee, particularly at the beginning of its work, to understand the Transit issue and (III) deliberative meetings, during which the committee discussed progress and procedural issues. ${ }^{204}$

\section{Interrogative meetings}

The committee held 16 interrogative meetings at which 62 witnesses from 32 separate organizations were heard. Among the witnesses were two Commissioners: Mario Monti (Internal Market, Service Customs and Taxation) and Anita Gradin (Immigration, Justice \& Home Affairs, Financial

\footnotetext{
199 Ibid. p. 3.

200 The committee's report was printed in four volumes under the reference number A40053/97: Volume I: Final Report and Recommendations, Volume II: Oral Evidence, Volume III: Written Contributions, and Volume IV: Contributions from the Institutions of the Union.

201 European Parliament (1997). Transit committee. Report on the Community Transit System (Volume I, A4-0053/97, 20.2.1997), p. 21.

202 European Parliament (1997). Transit committee. Chairman's report on the working methods of the Committee of Inquiry into the Community Transit System (PE 220.696/rev., 21.2.1997), p. 5.

${ }_{203}$ The written contributions received by the Committee are published in Volume III of the report: European Parliament (1997). Transit committee. Report on the Community Transit System (Volume III, A4-0053/97, 20.2.1997).

${ }_{204}$ European Parliament (1997). Transit committee. Chairman's report on the working methods of the Committee of Inquiry into the Community Transit System (PE 220.696/rev., 21.2.1997), pp. 1-2.
} 
Control, Anti-fraud and Relations with the European Ombudsman). ${ }^{205}$ The committee did not seek to test the constraints laid upon it by the Interinstitutional Agreement by inviting members of national governments to testify before it. ${ }^{206}$ Instead, the committee chose to hear a large number of national civil servants, mainly representatives of national customs services. None of the eight Member States which were asked for cooperation showed any reluctance to nominate someone to attend. Shackleton, the Head of Secretariat of the Transit committee, pointed out that some Member States even expressed some surprise that they had not been invited to express their point of view. However, as Shackleton considered: "whether they would have been so enthusiastic if the committee had expressly asked for a particular individual to attend is perhaps open to doubt". ${ }^{207}$

As a general rule, the witnesses were required to provide a written contribution in advance of their testimony to form a basis for questioning in the committee. ${ }^{208}$ Witnesses were heard in closed session on only a small number of occasions, each time at the request of the witness and with the agreement of the committee. ${ }^{209}$ Transcripts were taken of all evidence, but those given in closed session were not made public.

\section{Information meetings}

The Transit committee also arranged several 'information meetings' at which individuals and organizations provided, in a rather informal atmosphere, the benefit of their personal knowledge and expertise to the Transit committee. Such meetings were held with representatives of the Directorate General of the Commission responsible for customs matters (DG XXI), and other external organizations, such as the International Road Transport Union. ${ }^{210}$

\section{Deliberative meetings}

During its deliberative meetings the Transit committee discussed the progress of the inquiry and procedural issues. The committee's rapporteur prepared three 'progress reports' over the course of the inquiry for these meetings, summarizing the committee's findings to date and indicating areas still requiring attention. ${ }^{211}$

\footnotetext{
205 A list of hearings and witnesses can be found in Appendix I of the final report: European Parliament (1997). Transit committee. Report on the Community Transit System (Volume II, A4-0053/97, 20.2.1997).

206 European Parliament (1997). Transit committee. Chairman's report on the working methods of the Committee of Inquiry into the Community Transit System (PE 220.696/rev., 21.2.1997), p. 7.

${ }^{207}$ Shackleton (1998), p. 121.

208 European Parliament (1997). Transit committee. Chairman's report on the working methods of the Committee of Inquiry into the Community Transit System (PE 220.696/rev., 21.2.1997), p. 9.

209 European Parliament (1997). Transit committee. Report on the Community Transit System (Volume I, A4-0053/97, 20.2.1997), p. 22.

210 Ibid. p. 23.

211 Ibid. p. 23.
} 


\section{The gathering of written information}

On three occasions the committee circulated formal questions to all Member States with a view to gathering relevant information. On the first occasion, the committee requested details on the rights of witnesses in view of Rule 185 (7) EP Rules of Procedure, which stipulates: 'persons called to give evidence before a committee of inquiry may claim the rights they may enjoy when acting as witnesses before a tribunal in their country of origin. They must be informed of these rights before they make a statement to the committee'.

The committee chair, John Tomlinson, criticized this provision for being "unworkable", noting that even in the same Member State there was no single set of rules that could be applied. ${ }^{212}$ In the framework of the same request to the Member States, the Transit committee asked for an initial response on the five points of the committee's terms of reference. The second request took the form of a lengthy questionnaire with regard to detailed statistics and policy orientations from Member States. The third concerned a request for information concerning court cases connected with Transit crime. ${ }^{213}$ The repeated failure of several Member States to respond promptly to the committee's questionnaires led Tomlinson to call a press conference at which he named the various countries that had failed to produce an answer. Shackleton points out that this served to accelerate the return of information. ${ }^{214}$ However, the uncooperative attitude of several Member States caused serious delays to the committee's work and was, according to the committee, "indicative of a general lack of responsiveness on the part of some national authorities to the needs of the Inquiry". ${ }^{215}$

\section{Fact-finding visits}

Delegations of the Transit committee also undertook five on-the-spot factfinding visits to various locations in the European Union to look into specific points of interest and/or to meet specific interlocutors. ${ }^{216}$ After each of these visits, a specific report was prepared in which the findings of the delegation were summarized. ${ }^{217}$ In addition to these fact-finding visits, the Transit committee made use of reports drawn up by standing committees of the

\footnotetext{
212 European Parliament (1997). Transit committee. Chairman's report on the working methods of the Committee of Inquiry into the Community Transit System (PE 220.696/rev., 21.2.1997), p. 8.

${ }^{213}$ Cf. European Parliament (1997). Transit committee. Report on the Community Transit System (Volume I, A4-0053/97, 20.2.1997), p. 22; The text of the Committee's main questionnaire is published in Volume III of the final report; $c f$. European Parliament (1997). Transit committee. Report on the Community Transit System (Volume III, A4-0053/97, 20.2.1997).

214 Shackleton (1998), p. 128.

215 European Parliament (1997). Transit committee. Report on the Community Transit System (Volume I, A4-0053/97, 20.2.1997), p 22.

216 The reports of these delegations can be found in Volume III of the Committee's final report; $c f$. European Parliament (1997). Transit committee. Report on the Community Transit System (Volume III, A4-0053/97, 20.2.1997), pp. 315-351.

217 The reports of the fact-finding visits are published in Volume III of the report: European Parliament (1997). Transit committee. Report on the Community Transit System (Volume III, A4-0053/97, 20.2.1997).
} 
European Parliament.218 Committee members further gathered information through individual contacts and visits in pursuit of the committee's work. In many cases, these formed the subject of notices from members in order to share information gathered with the committee as a whole. Such meetings were frequently based on invitations from persons and organizations in the respective home states of committee members and from other interested third parties. ${ }^{219}$

\section{The committee's efforts to overcome the formal restraints}

The members of the Transit committee were aware of the limits which the provisions of the Interinstitutional Agreement imposed upon them. In this context, the committee observed: "a Committee of Inquiry of the European Parliament is not a judicial or even quasi-judicial body. Whether it should be is a separate issue, but the Committee could not (and at present committees of inquiry still cannot): administer oaths, legally oblige specific individuals to testify, publish names of persons implicated in the course of the inquiry, publish information received in confidential session, or apply sanctions for false or inaccurate testimony”. ${ }^{220}$

The committee's limited formal position became clear when it invited tobacco manufacturer Philip Morris Europe to give evidence concerning Transit fraud with regard to cigarettes. The company was reluctant to attend, arguing that the view of the tobacco manufacturers was best represented by their confederation rather than by one company. The Transit committee refused to accept this and it insisted that it was for the committee to decide which witnesses could best elucidate the fraudulent trade in cigarettes. The committee reminded the company that it could choose to give evidence in camera. Philip Morris eventually accepted this offer, perhaps also influenced by the fact that another cigarette manufacturer, Rothmans UK, had already given evidence to the committee in public. At the end of the meeting with representatives of Philip Morris Europe, which was held behind closed doors, the committee chairman invited the representatives of Philip Morris to review their transcript and to consider which passages were truly confidential. However, the representatives refused to allow their testimony to be made public. ${ }^{221}$ Hence the committee was not able to use the evidence in the final report. ${ }^{222}$

The committee was furthermore limited in terms of resources. The committee did not have direct access to outside expertise in the form of specialist advisers and it depended on a small secretariat, including three administrators, drawn temporarily from other parliamentary committees. Nor did the committee have

\footnotetext{
218 In particular, the Transit Committee drew heavily on the report on the visit by the Committee on Budgetary Control to the Port of Rotterdam and the report of the Committee on Transport on its visit to Frankfurt (Oder). Cf. European Parliament (1997). Transit committee. Report on the Community Transit System (Volume I, A4-0053/97, 20.2.1997), pp. 22-23.

219 Ibid. p. 23.

220 Ibid. p. 99.

221 Shackleton (1998), p. 122.

${ }^{222} \mathrm{Cf}$. Article $2(2)$ and 4 (1) of the Interinstitutional Agreement.
} 
a special budget to pursue its inquiries. It was also subject to the same rules as standing committees for the organization of visits outside the three places of work. On the other hand, the committee's work was given high priority in the provision of technical services, such as translation, interpretation, printing and meeting rooms. ${ }^{223}$ Aware of these constraints, the committee members had to seek responses to overcome their formal limitations. They did so by searching for informal mechanisms. ${ }^{224}$ Shackleton describes how the committee made use of the public character of the inquiry as a tool to make witnesses aware that they would be held to account by a wider audience than the one to which they gave evidence. The committee published its evidence inter alia by placing it on the internet ${ }^{225}$, and it managed to generate substantial media coverage. ${ }^{226}$ Additionally, in order to give the appearance of an investigation of a more inquisitorial nature, the meetings were held in small rooms where the committee members were seated in a U-shape. This enabled the committee members to be close to the witnesses, who were seated at the open end of the U-shape. According to Jan Mulder (ALDE), a member of the Transit committee, this proved useful as it made it clear to witnesses that the hearings were not just the regular business of a parliamentary committee. ${ }^{227}$ Witnesses were furthermore requested to produce a written statement before appearing before the committee and the committee insisted that all witnesses return their evidence signed, indicating that it was a true record of their testimony. In this way, there could be no dispute about what a witness had actually said before the committee.228 The committee's approach was successful as no witness sought to challenge these informal mechanisms. ${ }^{229}$

\subsubsection{The committee's final report}

On 19 February 1997, the Transit committee adopted its final report and submitted it to the Parliament. ${ }^{230}$ The report is discussed below in five separate points: (I) the conclusions, (II) the determination of responsibilities, (III) the

\footnotetext{
${ }^{223}$ Shackleton (1998), p. 118.

224 Ibid. p. 123.

225 Ibid. p. 123; European Parliament (1997). Transit committee. Chairman's report on the working methods of the Committee of Inquiry into the Community Transit System (PE 220.696/rev., 21.2.1997), p. 9.

226 In January 1997, for example, articles appeared in all the main Swiss newspapers where the Swiss customs authorities rejected the complaints of the Committee that their country was a haven for Transit criminals and that Switzerland provided inadequate legal assistance in the pursuit of Transit offences. Subsequently, in advance of the Amsterdam European Council, the German weekly Der Spiegel published an article in which it argued that the summit should be addressing the kind of fraud issues discussed in the Transit committee's report. In addition, a number of television and radio programmes were produced, including two full-length investigations on German TV and British radio that looked in-depth at butter and cigarette smuggling; $c f$. Shackleton (1998), p. 124.

227 Interview with Jan Mulder, 30 May 2011.

228 European Parliament (1997). Transit committee. Chairman's report on the working methods of the Committee of Inquiry into the Community Transit System (PE 220.696/rev., 21.2.1997), p. 9.

229 Shackleton (1998), p. 123.

230 The four volumes of the report can be found under the reference number A4-0053/97.
} 
recommendations, (IV) the committee's assessment of its performance, and (V) the minority opinion of Jean-Pierre Thierry (I-EDN).

\section{Conclusions}

The committee's major finding was that the mechanisms for managing Transit were outdated and that revision of the existing Transit regime was required. The committee concluded: "a system designed to cope with a relatively small amount of trade in the late sixties within a group of six Community countries simply cannot cope with today's volumes of trade across a group of 23 countries". ${ }^{231}$ This was illustrated by a German witness's observation that "the European customs services use administrative methods that were commonly practiced in the German Empire around 1900, with customs stamps which practically invite forgery and which are indeed frequently forged". 232 The system had provoked the loss of several million ECU of VAT, customs duties and excise revenue, both for national budgets or for that of the $\mathrm{EU}$, and the committee found that organized crime was deeply involved in the Transit fraud. ${ }^{233}$ The committee concluded that the introduction of the Single Market, with its removal of internal frontiers, caused serious problems in the field of Transit: "the introduction of the Single Market has been followed by a reduction in the numbers and morale of customs services, whose different powers, legal constraints, traditions and outlooks have hindered effective cooperation". ${ }^{234}$ The committee concluded: "Goods cross borders, criminals cross borders, profits from illegal activities cross borders, public authority stops at the borders". ${ }^{235}$

\section{Responsibilities}

The committee considered it impossible to attribute sole responsibility for the crisis in the Transit regime to a specific person or institution. The Commission and the Member States were criticized but without being singled out for particular blame. The problems in the Transit system were principally due to the weakness of the system and mistakes had generally been of omission rather than commission. ${ }^{236}$ The committee noted: "responsibility for the state of affairs is thus shared between all the legislators and managers of the system". ${ }^{237}$ It deplored the fact that both groups had proved unable "to protect the legitimate interests of those using the Transit System, the taxpayer at large and the economy as a whole". ${ }^{238}$

\footnotetext{
231 European Parliament (1997). Transit committee. Report on the Community Transit System (Volume I, A4-0053/97, 20.2.1997), p. 35.

232 Oral evidence of Mr. Schmidt, Director-General of the Federation of German LongDistance Hauliers (BDF); $c f$. European Parliament (1997). Transit committee. Report on the Community Transit System (Volume II, A4-0053/97, 20.2.1997), p. 322.

233 European Parliament (1997). Transit committee. Report on the Community Transit System (Volume I, A4-0053/97, 20.2.1997), p. 13.

${ }^{234}$ Ibid. p. 14.

235 Ibid. p. 13.

236 Ibid. p. 109.

237 Ibid. p. 109.

238 Ibid. p. 109.
} 
The crisis had been exacerbated by the introduction of the Single Market and the associated removal of internal frontiers. The committee concluded that, even though it was evident that an already creaking Transit System would be exposed to large-scale fraud at that point, the responsible technical and political authorities took no action to avert the crisis. No serious effort was made to enhance cooperation or coordination between national customs services and, at the same time, their effectiveness was compromised by largescale personnel cuts. ${ }^{239}$

\section{Responsibilities of the Commission}

The committee blamed the Commission not only for a complete lack of foresight, but also for inaction and negligence. According to the committee, the passive attitude of the Commission had delayed the computerization of the Transit System. The committee noted that the establishment of the single market in 1993 was guided "by the principles of market liberalization and the abolition of controls rather than those of safeguarding revenue and maintaining the Community's own resources". ${ }^{240}$ Despite repeated warnings from numerous organizations concerning the threats to a system increasingly exposed to fraud, the Commission had failed to take appropriate measures to bring the Transit System, which was created in 1968 for a Community of six Member States, into line with new realities: a European Union of 15 Member States, a substantial increase in international traffic and the introduction of the single market without internal borders. ${ }^{241}$ Although the committee stated that "a competent administration does not create a system unless it also has the instruments necessary to manage it" 242 , it acknowledged that the Commission was "severely constrained in the legislative area", as it relied on the support and cooperation of the political authorities, particularly the Council. ${ }^{243}$

\section{Responsibilities of the Council and the Member States}

The committee noted that "the Council failed to recognize the new challenges posed by the Single Market project and the customs services proved unable to adapt ways of thinking that were manifestly out of date". ${ }^{244}$ Moreover, on the basis of the remarks made by Commissioner Monti, the committee strongly condemned the "contradictory and ambiguous attitude" of the Member States and the Council which consisted of "making declarations of intent extolling the virtues of more effective European Union measures to combat fraud, but of acting in such a way as to make such measures practically impossible or even deliberately hindering them by seeking to preserve, for whatever purpose, the prerogatives of the national administrations to the detriment of the Commission's powers". ${ }^{245}$ The committee was further struck by the fact that the national customs authorities were generally unaware of the scale of the

\footnotetext{
239 Ibid. p. 109.

240 Ibid. p. 50.

${ }^{241}$ Ibid. pp. 99-100.

${ }^{242}$ Ibid. p. 100.

${ }^{243}$ Ibid. p. 103.

${ }^{244}$ Ibid. p. 14.

${ }^{245}$ Ibid. p. 104.
} 
crisis, and that the Member States displayed not only ignorance or indifference, but also inaction in the face of the substantial losses to public revenue. The committee was also concerned by the Member States' "lack of enthusiasm" for releasing the budgetary resources needed to finance the computerization of the Transit System. ${ }^{246}$

\section{Recommendations}

Rather than just recognizing the problem, the committee also formulated recommendations to improve matters. A thorough investigation of possible measures resulted in a list of 38 concrete recommendations. ${ }^{247}$ These recommendations included the creation of a single EU framework for customs services, the adoption of concrete measures aimed at allowing customs services to function in a more uniform and consistent manner, and the computerization of the Transit System. ${ }^{248}$

\section{The committee's assessment of its performance}

The Transit committee was satisfied with its performance. It claimed that it had been able to use the right of inquiry to make a difference to a particular policy area. In the course of its work, it observed significant changes in the importance given to the Transit problem and it considered that its very existence had already made a difference in four respects. ${ }^{249}$

Firstly, the committee concluded that it had succeeded in bringing the issue of Transit out of the administrative undergrowth and into the political arena. Secondly, it concluded that it had brought an end to the ignorance surrounding the Transit System among the actors involved. Thirdly, the committee was satisfied with the increased level of urgency and seriousness in the debate on reform of the Transit System. It observed that this was particularly true with regard to the attitude of the Commission. During the work of the committee, the Commission had given the issue a higher level of priority, which according to the committee - was a direct result of the existence of the inquiry committee. Finally, the Transit committee concluded that it had been successful in obtaining commitments on the future direction of policy. The most obvious case in this respect was the Commission's agreement not to extend the Transit System further until it had been reformed and computerized. ${ }^{250}$

\section{$V \quad$ Minority opinion}

One of the members of the Transit committee delivered a minority opinion pursuant to paragraph 10 of Rule 176 (currently: Rule $185(10)$ ) of the Rules of

\footnotetext{
${ }^{246}$ Ibid. p. 105.

${ }^{247}$ Ibid. pp. 171-179.

${ }^{248}$ Ibid. pp. 171-179. In its Annual Report for 1994 the European Court of Auditors too recognized computerization and legal reform of Community transit as key elements for fighting fraud; $c f$. European Court of Auditors (1995). Annual Report for 1994 (OJ C 303, 14.11 .1995 , p. 1).

249 European Parliament (1997). Transit committee. Report on the Community Transit System (Volume I, A4-0053/97, 20.2.1997), pp. 16-17.

250 Ibid. p. 166.
} 
Procedure. Jean-Pierre Thierry (Group of Independents for a Europe of Nations, I-EDN) took the view that the establishment of a framework for customs services to combat fraud in the Community Transit System would be an unjustifiable infringement of the sovereignty of the Member States. ${ }^{251}$

\subsubsection{Chairman's evaluation of the committee's working methods}

The chairman of the Transit committee, John Tomlinson (PES), provided the members of the European Parliament with an internal document in which he evaluated the work of the Transit committee. ${ }^{252}$ This evaluation, which was submitted to Parliament on 21 February 1997, was intended to serve as a background brief on the work of committees of inquiry with regard to possible renewed negotiations with the Council and the Commission to revise the Interinstitutional Agreement of 1995. ${ }^{253}$ The chairman's evaluation consists of three parts: the first considers the way the committee organized its work internally, the second examines how it developed its external contacts, and the third looks at the specific issue of the rights and obligations of witnesses before a committee of inquiry.

\section{Internal organization}

With regard to the internal organization of the committee's work, Tomlinson evaluated the room in which the oral hearings were held. The room was adapted to make it possible to place two seats for witnesses in the centre of the room, in such a way that all committee members could see and could be seen by the witnesses. He found that this proved a "successful experiment", which led to his recommendation that "Committees of Inquiry should give careful consideration as to the room in which they wish to hold their hearings of witnesses with a view to ensuring that it provides the best environment for cross-examining witnesses". ${ }^{254}$

Furthermore, he discussed the absence of firm rules with regard to the treatment of confidential documents. To remedy this, he called on the Parliament to examine the possibility of providing a safe area for keeping confidential material in secure conditions, both during and after the life of the committee.

Tomlinson pointed out that the resources available to the committee were insufficient, both in relation to staff and to finance. He observed with regard to financial resources that, had the committee been granted resources equivalent to those available to committees of inquiry in some Member States, it would "doubtless have achieved more". ${ }^{255}$ Tomlinson touched on the fact-finding

\footnotetext{
${ }^{251}$ Ibid. pp. 191-194.

252 European Parliament (1997). Transit committee. Chairman's report on the working methods of the Committee of Inquiry into the Community Transit System (PE 220.696/rev., 21.2.1997).

${ }^{253}$ It should be recalled that article 6 of that agreement specifies that such a revision could take place in the light of experience.

254 European Parliament (1997). Transit committee. Chairman's report on the working methods of the Committee of Inquiry into the Community Transit System (PE 220.696/rev., 21.2.1997), p. 2.

255 Ibid. p. 4.
} 
visits of the committee as an example. These visits were, according to him, "invaluable in expanding the level of information available to Committee members". ${ }^{256}$ However, in spite of a general feeling that there were not enough such visits, the financial resources did not allow for that.

With regard to staff, "in view of the difficulty of creating a permanent secretariat for committees of inquiry”, he recommended that the Parliament should examine the possibility of seconding an outside expert with specific knowledge for the duration of an inquiry. ${ }^{257}$

\section{External contacts}

Concerning relations with actors outside the Parliament, Tomlinson observed that the Transit committee was more than pleased with the overall response to its call for witnesses and evidence in the Official Journal and on the internet. He noted that the evidence received ensured the credibility of the conclusions and the legitimacy of the report. ${ }^{258} \mathrm{He}$ furthermore stressed the importance of close contacts with the Commission, the Member States and national parliaments: "close contacts should be developed with national parliaments from the beginning of a committee of inquiry. This may permit an exchange of views during the work of the committee but should above all be seen in terms of the follow-up on the work of the committee at the national level".259

\section{Rights and obligations of witnesses}

Since the provisions regarding the rights and obligations of witnesses had had a particularly limiting effect on what the committee could do, Tomlinson devoted the third part of his internal report to this issue. The committee did not seek to test the formal constraints. No national minister had been invited and the committee accepted that national authorities had the right to designate the servant of their own choosing, even though the committee might sometimes have preferred someone else to appear before it.260 The committee was not satisfied with the right of witnesses to provide testimony in camera. Tomlinson therefore recommended that this provision be renegotiated to give the initiative on requests for in camera sessions to the committee: "witnesses should retain the right to request such a session $[\ldots]$ but they should not have a unilateral right to decide the nature of the proceedings within the Parliament”. ${ }^{261}$ Moreover, he criticized the provision in the Rules of Procedure stipulating that any witness should enjoy the same rights as they would before a tribunal in their country of origin. This provision proved to be unworkable, since it emerged that even in one state there was no single set of rules that could be applied. In the context of the Transit inquiry, this heterogeneity did not prove an obstacle to the committee, but Tomlinson emphasized the importance of giving further consideration to the issue. ${ }^{262}$ With regard to the

\footnotetext{
256 Ibid. p. 4.

257 Ibid. p. 4.

258 Ibid. p. 5.

259 Ibid. p. 7.

260 Ibid. p. 7.

261 Ibid. p. 8.

262 Ibid. p. 8.
} 
obligations of witnesses, the committee accepted that it could not administer oaths and that private individuals could not be obliged to cooperate in the course of the inquiry. Nor could sanctions be imposed on them should they refuse to attend or give false evidence. ${ }^{263}$ Tomlinson stressed the importance of the informal procedures which the committee designed to underline the seriousness of giving evidence: "all committees of inquiry should consider very carefully the way in which they organize their work so as to maximize the credibility of the taking of evidence and to minimize the opportunities for witnesses to weaken the impact before such a committee". ${ }^{264}$ The Transit committee achieved this by requiring a written contribution from witnesses before the giving of evidence, by requesting witnesses to return their evidence signed after giving evidence and by giving the greatest-possible publicity to the testimonies in order to ensure that those outside as well as inside the committee could judge the nature and quality of the evidence given. ${ }^{265}$

\subsubsection{Plenary debate of 12 March 1997}

The Transit committee presented its report in plenary on 12 March 1997.266 The report was debated with the two responsible Commissioners, Giorgio Monti and Anita Gradin, and a representative of the (Dutch) Presidency-inOffice of the Council, Michiel Patijn.

The Transit committee was praised for its work not only by MEPs, but also by the representatives of the Commission and the Council. Monti emphasized that the Commission was prepared to assume its responsibilities and he called on the Council and the Member States to do the same by making their political contribution and rapidly adopting the proposals put before them. Patijn stressed the Council's commitment to tackle fraud involving EC budget funds. He refrained from commenting on the substance of the report on behalf of the Council, as it had not yet been discussed within the Council. However, Patijn pointed out that - partly as a result of the existence of the Transit committee much had already been done on both the national and Community levels to combat Transit fraud. He furthermore promised to get the report placed on the Council agenda as soon as possible.

From an institutional perspective, it is worth mentioning the contribution of Edith Müller (Greens), who was a member of the Transit committee. Müller was satisfied with the right of inquiry of the European Parliament and its use by both the Transit and the BSE committee. ${ }^{267}$ However, if the right of inquiry was to be made even more effective in future, she stated, "the existing loopholes must be closed and present weaknesses remedied". To that end she proposed the following six points:

\footnotetext{
263 Ibid. p. 9.

264 Ibid. p. 10.

265 Ibid. p. 9.

266 The written transcripts of the plenary debate of 12 March 1997 are available online at: http://www.europarl.europa.eu/calendar/calendar?APP=DEBATS\&LANGUE=EN (click on '12 March 1997' and subsequently on 'Community Transit System').

267 Although the BSE Committee had been established after the Transit Committee had started its inquiry, it submitted its final report to Parliament two weeks earlier than the latter. Section 2.5.2 discusses the BSE inquiry.
} 
"(1) those in positions of political responsibility, whether in the EU institutions or in Member States, must have an obligation to appear and give evidence to the committee. Surely it cannot be left to the discretion of Mr Hogg, the Minister of Agriculture, whether he justifies his actions to the BSE Committee or not.268

(2) Secondly, committees of inquiry must be granted a general right to summon witnesses, swear them in and impose penalties for infringements of the rules.

(3) Thirdly, the power of investigation must be extended to cover the actions of individuals and corporate entities, even if they have not been operating on behalf of the Community or the Union, as for instance in the tobacco industry.

(4) The fourth point follows from this, namely that individuals and corporate entities must also be compelled to submit documents;

(5) the fifth point is that committees of inquiry will need to have their own right of access to all documents of the European institutions in future.

(6) And one final point: the secretariats must be better equipped in future. Michael Shackleton and his crew often managed to do the impossible, and the demands made of them sometimes bordered on the unreasonable".

The committee's report was adopted on 13 March 1997.269

\subsubsection{Follow-up to the inquiry}

The Parliament's call for urgent action was taken seriously by the Commission. On 30 April 1997, less than two months after the Parliament adopted the Transit report, the Commission submitted an 'Action plan for Transit in Europe' to the European Parliament and the Council. The Commission stressed the importance of the work of the committee, "which greatly contributed to convincing the system's administrators and users of the urgent need for radical action". ${ }^{270}$ The Commission further stated: "The work of the Committee of Inquiry, together with its conclusions and recommendations, was instrumental in the Commission's own policy review; it has greatly contributed to bringing out the full political implications of what is a rather technical subject, and placing it in the wider context of Community customs policy and customs cooperation between States". ${ }^{271}$ In its action plan, the Commission proposed various measures largely corresponding to the recommendations of the inquiry committee. ${ }^{272}$ In keeping with the Commission's action plan and one of the

\footnotetext{
${ }^{268}$ Edith Müller referred to the refusal of the UK Minister of Agriculture, Douglas Hogg, to appear before the committee of inquiry into the BSE crisis. $C f$. Section 2.5.2.

269 Cf. OJ C 115, 14.4.1997, p. 157.

270 European Commission (1997). Action plan for transit in Europe - a new customs policy

(OJ C 176, 10.6.1997), Section 1.5.

271 Ibid. Section 1.5.

${ }^{272}$ European Commission (1997). Action plan for transit in Europe - a new customs policy (OJ C 176, 10.6.1997), Annex.
} 
recommendations of the Transit committee, a legal basis was adopted for the introduction of a new computerized Transit System (NCTS) in 1999. This computerized system, which replaced the existing vulnerable paper-based Community Transit procedure, was implemented in several phases and completed in January 2006. ${ }^{273}$ In 2001, in parallel with the computerization, the Commission presented a reform of the legal basis for the Transit System. ${ }^{274}$

The European Court of Auditors investigated the Community Transit System in 2006. ${ }^{275}$ The audit was conducted with a twofold objective. Firstly, it was to obtain assurances that the Member States were applying the revised legal provisions correctly and that the new procedures for Transit had been well coordinated by the Commission and properly implemented by the Member States. The second objective was to analyze the implementation of the measures recommended by the European Parliament ${ }^{276}$, the Council277 and the Court of Auditors ${ }^{278}$, and the measures envisaged in the Commission's action plan. ${ }^{279}$ Although the Court of Auditors still identified shortcomings in the Transit System, it concluded that the Commission had put in place the key elements of the 'Action plan for Transit in Europe'. 280 Moreover, the Commission had successfully computerized the Transit procedure. ${ }^{281}$

Shackleton concludes that the Transit committee provoked a number of specific changes which would almost certainly not have taken place had the committee not existed. ${ }^{282}$ He notes that the influence of the inquiry went even further than the changes in the Community Transit regime. The committee succeeded in influencing the broader debate on the way in which criminality can be combated at a European level and it provided a wide range of very specific evidence to foster that discussion. ${ }^{283}$ The Committee of Independent Experts, which was established by the European Parliament to investigate claims of fraud, mismanagement and nepotism within the Commission, indeed observed that the findings of the Transit committee gave a 'boost' to the debate on better cooperation between national judicial authorities in the context of combating fraud by UCLAF (at present: OLAF).284 The British Financial Times wrote in

\footnotetext{
${ }_{273}$ European Court of Auditors (2006). Special Report No. 11/2006 on the Community transit system, together with the Commission's replies (OJ C 44, 27.2.2007), p. 6.

${ }^{274}$ Commission Regulation (EC) No 2787/2000 of 15 December 2000 amending Regulation (EEC) No 2454/93 laying down provisions for the implementation of Council Regulation (EEC) No 2913/92 establishing the Community Customs Code (OJ L 330, 27.12.2000, p. 1).

275 European Court of Auditors (2006). Special Report No. 11/2006 on the Community transit system, together with the Commission's replies (OJ C 44, 27.2.2007).

276 European Parliament (1997). Transit committee. Report on the Community Transit System (Volume I, A4-0053/97, 20.2.1997), pp. 171-179.

277 OJ C 327, 7.12.1995, p. 2.

278 European Court of Auditors (1995). Annual Report for 1994 (OJ C 303, 14.1 1.1995).

279 European Commission (1997). Action plan for transit in Europe - a new customs policy (OJ C 176, 10.6.1997).

280 European Commission (1997). Action plan for transit in Europe - a new customs policy (OJ C 176, 10.6.1997).

281 European Court of Auditors (2006). Special Report No. 11/2006 on the Community transit system, together with the Commission's replies (OJ C 44, 27.2.2007), pp. 3-11.

282 Shackleton (1998), p. 125.

283 Ibid. 126.

${ }^{284}$ Committee of Independent Experts (1999c), p. 10.
} 
its leader column: "This was the first EU parliamentary inquiry set up under the provisions of the Maastricht Treaty. The result is a welcome sign that the parliament can be more than a talking shop, can bend its energies to an important problem neglected by the Brussels bureaucracy, and is able to come up with some practical remedies". ${ }^{285}$

\subsubsection{Inquiry into BSE}

\subsubsection{Subject, establishment and duration of the inquiry}

At its plenary session of 18 July 1996, the Parliament established a temporary committee of inquiry to investigate the crisis following the outbreak of BSE, also known as 'mad cow disease'. 286

\section{Background information on the inquiry subject}

BSE (bovine spongiform encephalopathy) is an infectious disease in the brain of cattle. The first cases of BSE were identified in the UK in 1986 and the outbreak of the disease peaked between 1990 and 1994. BSE is caused by prions, which are infectious proteins. BSE was said to stem from the introduction of an American system of manufacturing meat-and-bone meal using lower temperatures and no chemical solvents. This method claimed to save energy and avoid environmental damage from possible chemical emissions. ${ }^{287}$ The UK government, unlike those of other EU Member States, authorized the change in the system for manufacturing meat-and-bone meal, which allegedly lead to the outbreak of BSE. 288

\section{The BSE committee}

The committee of inquiry was established due to significant indications that the BSE problem had not been managed with the necessary vigilance by the Commission and the Member States in their responsibility for monitoring the activities of economic operators. The measures and initiatives taken by the Commission and the Members States had further not proved sufficiently effective to protect the health of the public in the European Union and to combat BSE. 289 The request for the establishment of a committee of inquiry summarized the allegations as follows:

285 Financial Times, 13 March 1997, in an editorial titled, 'Fraud across EU Frontiers'. Cf. Shackleton (1998), p. 124.

286 Decision setting up a temporary committee of inquiry, OJ C 261, 9.9.1996, p. 132.

287 European Parliament (1997). BSE committee. Report on alleged contraventions or maladministration in the implementation of Community law in relation to BSE (Part B, A40020/97/B, 7.2.1997), p. 27.

288 European Parliament (1997). BSE committee. Report on alleged contraventions or maladministration in the implementation of Community law in relation to BSE (Part AI and AII, A4-0020/97/A, 7.2.1997), p. 6.

${ }^{289} \mathrm{Cf}$. Request for the setting up of a temporary committee of inquiry to investigate alleged contraventions or maladministration in the implementation of Community law in relation to bovine spongiform encephalopathy (BSE) OJ C 261, 9.9.1996, p. 133. 
“- According to an internal Commission document published in the press, the Commission underestimated its duty to inform the Member States in an appropriate manner about the risks connected with BSE and encouraged one Member State no longer to publish its research findings.

- Press revelations indicated that the export ban imposed by the Commission on 27 March 1996 with regard to bovine meat had not been observed by certain Member States.

- Although the British Government banned the sale, in July 1988, of feeding stuffs for ruminants containing ruminant protein, the Council did not adopt the first measures in this connection until 1990. Moreover, the European Parliament had called on the Commission already in 1990 to bring forward a proposal with regard to prohibiting the use as animal feed of animal protein recycled from carcasses.

- Further to a technological change in the manufacturing process of meal of animal origin, the disease seems to have appeared without the Member States or the Commission taking the precaution of effectively ascertaining the harmlessness of these new processes and the practices of the businesses concerned." 290

The committee of inquiry was composed of 19 full members and 19 substitutes. It was chaired by the German MEP Reimer Böge (EPP-ED) and the Spanish MEP Manuel Medina Ortega (PES) was appointed as rapporteur. The Parliament asked the BSE committee "to clarify the nature and causes of the alleged contravention or maladministration of the application of Community law by the competent authorities of the European Union and the Member States with regard to BSE, without prejudice to the jurisdiction of the Community and national courts". ${ }^{291}$ The main objective of the inquiry was to identify any malfunctioning and to formulate conclusions in the light of the requirements of public health. ${ }^{292}$ Initially the committee had three months to formulate its conclusions and recommendations. However, the mandate was extended for a further three months as it transpired that the period of three months was too short. ${ }^{293}$ In February 1997, after six months of work, the BSE committee adopted its report. ${ }^{294}$

\subsubsection{Concurrence with judicial investigations}

Fears about dealing with matters sub judice led to initial hesitations in the Parliament to set up a committee of inquiry. ${ }^{295}$ Article 226 TFEU and Article 2

\footnotetext{
290 Ibid. p. 133.

291 Ibid. p. 134.

292 Ibid. p. 134.

293 European Parliament (1997). BSE committee. Report on alleged contraventions or maladministration in the implementation of Community law in relation to BSE (Part B, A40020/97/B, 7.2.1997), p. 43.

294 The inquiry report was divided into two parts, the first (Part A) presenting the work of the committee and basic data, the second (Part B) presenting the results of the inquiry. Annexed are the documents on which its findings were based and a literal transcription of the evidence hearings. The reference number is A4-0020/97.
}

${ }^{295}$ Westlake (1997), p. 22. 
(3) IIA stipulate that the European Parliament may not establish a committee of inquiry if at the same time (i.e. at the moment of establishment) legal proceedings are ongoing for the same facts before a national or a Union court. ${ }^{296}$ Considering that legal proceedings with regard to BSE were ongoing both at the national and the Community level, it was indeed questionable whether a parliamentary inquiry was admissible in the light of the sub judice rule. ${ }^{297}$ Such questions arose in particular with respect to case T-53/96 before the Court of First Instance of the European Communities. ${ }^{298}$ The applicant in this case, a French trade union claimed compensation from the Commission for damages suffered as a result of the delay in adopting measures to deal with BSE. The BSE committee, however, claimed that the sub judice rule did not apply. It highlighted the difference between judicial investigations and parliamentary investigations: “The committee's exercise of the functions entrusted to it is [...] to be carried out without prejudice to the jurisdiction of the Community and national courts". It is, therefore, not for the Parliament to determine individual responsibilities which must be the subject of actions before criminal and civil courts by the victims of the crisis. The attribution of political responsibility, and whether the committee should propose initiatives to that end to the plenary of the Parliament, is another matter altogether". ${ }^{299}$

Following a German logic ${ }^{300}$, undoubtedly influenced by its German chairman, the BSE committee thus pointed out that judicial and parliamentary investigations serve different purposes. Judicial investigations aim to determine criminal or civil responsibilities, whereas parliamentary investigations aim to determine political responsibilities. Although this consideration might seem reasonable in theory, it is highly questionable whether it is tenable in practice. At least with regard to the abovementioned case, T-53/96, it is arguable that the BSE committee wanted to investigate the same matter as the Court of First Instance. In view of the similarity between, on the one hand, assessing the lawfulness of the Commission's delay in adopting BSE measures, and, on the

\footnotetext{
$296 \mathrm{Cf}$. Section 2.4.3.1 on the sub judice rule.

297 See also: Beckedorf (1997), pp. 239-241.

298 Case T-53/96, Syndicat des producteurs de viande bovine de la coordination rurale and Others $\mathrm{v}$ European Commission. Other legal actions relating to BSE were:

- an action for annulment; Case C-180/96, United Kingdom v European Commission. By order of 12 July 1996, the Court rejected an application for suspension of implementation of the ban;

- an action for annulment Case T-76/96, National Farmers Union and others v European Commission;

- a reference to the Court for a preliminary ruling; Case C-157/96 in connection with a case before the High Court of Justice, Queen's Bench Division brought by the National Farmers Union and others against the Ministry of Agriculture, Fisheries and Food concerning the measures taken by the Ministry's departments in implementing the export ban of 27 March 1996.

299 European Parliament (1997). BSE committee. Report on alleged contraventions or maladministration in the implementation of Community law in relation to BSE (Part AI and AII, A4-0020/97/A, 7.2.1997), p. 4.

${ }^{300}$ Committees of inquiry of the German Bundestag may investigate issues which have given rise to court proceedings. However, they may not assess concrete judgments or decisions of the judiciary, since that would imply that inquiry committees interfere in judicial business rather than in parliamentary business. Cf. Schulte (2003), p. 506.
} 
other hand, assessing the Commission's handling of the BSE crisis from a political point of view, a valid claim can be made that the Parliament breached the sub judice rule by establishing a committee of inquiry. At the same time, however, the question arises whether it is only the Parliament's task to assess comprehensively whether or not its activities conflict with the competences of other institutions. Section 2.4.5.1 mentions that any decision to establish a committee of inquiry can be challenged by means of an action for annulment $e x$ Article 263 TFEU. However, none of the possible applicants (e.g. the European Commission) brought such an action before the ECJ. There was merely an exchange of letters between the Parliament and the Commission, in which the latter suggested that the establishment of a committee of inquiry ran counter to the sub judice rule. In the same letter, however, the Commission ensured full cooperation with the committee of inquiry. ${ }^{301}$

It is perfectly reasonable to argue that the Parliament established a committee of inquiry in breach of the sub judice rule. However, the lack of resistance to the establishment of the inquiry committee allowed the BSE committee to start its work. The chair of the BSE committee, Reimer Böge, observed that the sub judice rule continued to be an issue after the establishment of the BSE committee: "The sub judice rule actually was an important issue not only with regard to the establishment of the committee of inquiry, but also during the work of the committee of inquiry. The Commission actually could have counteracted certain decisions of the committee of inquiry, such as requests for documents. However, it was under enormous public pressure, with articles appearing in newspapers all over Europe on an almost daily basis. The Commission therefore chose not to offer resistance to the inquiry". ${ }^{302}$

\subsubsection{Inquiry proceedings}

The BSE committee conducted its work between 17 August 1996 and 7 February 1997. With a view to ensuring maximum transparency for its activities, the committee decided to operate as much as possible on the basis of public hearings. This principle was maintained at most of its meetings, except for the meetings in which the committee discussed internal matters such as the coordination of activities and the assessment of testimonies and documents received. ${ }^{303}$

\section{Gathering of oral and witten evidence}

The BSE committee held 16 oral hearings during which it questioned 34 witnesses. Among the witnesses were five Commissioners (Santer, the Commission President, Bonino (Health and Consumer Protection), Fischler (Agriculture and Rural Development), Flynn (Employment, Social Affairs and Equal Opportunities), and Van Miert (Competition)), and two former Commissioners (MacSharry (Agriculture and Rural Development during Delors

\footnotetext{
${ }^{301} C f$. Beckedorf (1997), p. 241.

${ }^{302}$ Interview with Reimer Böge, 21 June 2011.

303 European Parliament (1997). BSE committee. Report on alleged contraventions or maladministration in the implementation of Community law in relation to BSE (Part B, A40020/97/B, 7.2.1997), p. 4.
} 
II) and Steichen (Agriculture and Rural Development during Delors III)). The BSE committee further heard high officials from the Commission, national civil servants and external experts in the field of BSE. ${ }^{304}$ The fact that the BSE committee heard several external experts (including veterinary medics, microbiologists, zoologists, agricultural engineers and pharmacists) suggests that it was willing to investigate the BSE issue thoroughly. According to its chairman, this was in line with the committee's intentions: "Of course there were Members who had already put the blame on the Commission before even investigating its actions. However, it was a challenge for me to chair the committee in such a way that it would analyze the handling of the BSE crisis thoroughly and on the basis of facts, not on the basis of biased positions. After all, the main aim of an inquiry is not to remove those who are guilty from office, but rather to bring about policy changes which matter for the citizens of Europe". 305

After its oral hearings, the committee put numerous additional questions to witnesses in writing, which the committee considered a most valuable means of gaining further details, clarifying and confirming witnesses' oral contributions. The largest number of written questions was addressed to the Commission. The BSE committee deemed the Commission's replies extremely valuable for illustrating the technical aspects of the subject and for comprehending the reasons underlying the successive political decisions and legislative measures. ${ }^{306}$

At the outset of the investigation, the Parliament was not entirely sure that the Commission would cooperate with the BSE committee. As the chairman of the BSE committee stated: "We exercised the right of inquiry for the first time since its recognition in the Maastricht Treaty. It consequently was a political minefield and no one knew: how will the Commission react? What kind of information will the Commission give us? How will the Member States react? Particularly regarding this rather sensitive BSE issue this was a gamble". ${ }^{307}$

At least with regard to the Commission, this gamble turned out well for the BSE committee. The close institutional ties between the Commission and the Parliament ensured the cooperation of the Commission throughout the inquiry, in the same way as for the Transit inquiry as discussed in Section 2.5.1.2. ${ }^{308} \mathrm{In}$ addition to these close constitutional ties, the public interest and resulting public pressure on the Commission lent the BSE committee a helping hand. This was true in a direct sense, in that the Commission gave the BSE committee access to sensitive information, but also in an indirect way, in the sense that journalists, with their own sources and ways of finding relevant

\footnotetext{
${ }^{304}$ Ibid.pp. 4-16. Literal transcriptions of all the hearings can be found in Part C of the Final Report: European Parliament (1997). BSE committee. Report on alleged contraventions or maladministration in the implementation of Community law in relation to BSE (Part C, A40020/97/C, 7.2.1997).

305 Interview with Reimer Böge, 21 June 2011.

306 European Parliament (1997). BSE committee. Report on alleged contraventions or maladministration in the implementation of Community law in relation to BSE (Part B, A40020/97/B, 7.2.1997), p. 3.

${ }^{307}$ Interview with Reimer Böge, 21 June 2011.

${ }^{308}$ Shackleton (1998), p. 119.
} 
information, became interested in the BSE issue. ${ }^{309}$ The Commission authorized the attendance of all the officials invited and it went further by releasing the tapes of a whole series of meetings of the Standing Veterinary committee going back to the 1980s, in which some of the officials that were invited had participated. ${ }^{310}$ On several occasions, the BSE committee was informed off-the-record - by persons who preferred to remain anonymous - of the existence of relevant Commission documents. The BSE committee received this information gratefully and it was subsequently able to view these documents - which had previously not been known to exist - after sending specific official requests to the Commission to forward these documents. ${ }^{311}$

However, the situation was different when dealing with members of national governments. The BSE committee acknowledged that it was difficult to hold the Council and individual Member States to account for their actions. Therefore, and also in view of the limited time at its disposal, the committee concentrated mainly on the Commission. ${ }^{312}$ It did manage to question the Irish Minister of Agriculture, Sean Yates, though he came in his capacity as President-in-Office of the Council rather than as a national minister. ${ }^{313}$ The committee was less successful in getting the British Agriculture Minister, Douglas Hogg, to attend. He chose not to appear and to send the Permanent Secretary from the Ministry of Agriculture in his place. The then Prime Minister, John Major, supported this decision. In response to the suggestion that Hogg might appear before the committee of inquiry, Major stated: "no minister of the crown would ever appear when summoned by the European Parliament. Those calling for him to do so should go and boil their heads". ${ }^{314}$ The BSE committee qualified Hogg's refusal to give evidence as a breach by the British Government of the Member States' obligations under Article 3 (2) IIA, all the more since a 'Permanent Secretary' (who stood in for the Minister) could not be considered to be a member of Government within the meaning of that provision. ${ }^{315}$ However, as Section 2.4.4.1 shows, the Interinstitutional Agreement does not provide for a general right of summons vis-à-vis members of national governments. Article 3 (2) IIA stipulates that members of national governments may be invited, i.e. not summoned, to appear before a committee of inquiry. It thus follows that the refusal of Douglas Hogg to appear and testify before the BSE committee was not in breach of the Interinstitutional Agreement. ${ }^{316}$ Apparently the BSE committee itself was not absolutely convinced that the UK violated the Interinstitutional Agreement. It rather

\footnotetext{
309 Two examples are Jean Quatremer and André Riche, who worked for the French newspaper Libération and the Belgian newspaper Le Soir respectively. Both journalists wrote numerous articles about the role of the Commission in policy making relating to BSE. $C f$. Shackleton (1998), p. 124.

310 Ibid. pp. 120-121.

${ }^{311}$ Interview with Reimer Böge, 21 June 2011.

${ }^{312} C f$. Interview with Reimer Böge, 21 June 2011.

313 Shackleton (1998), p. 119.

${ }^{314}$ Castle (1996).

315 European Parliament (1997). BSE committee. Report on alleged contraventions or maladministration in the implementation of Community law in relation to BSE (Part AI and AII, A4-0020/97/A, 7.2.1997), p. 14.

316 See also: Shackleton (1998), p. 120.
} 
appears that this reproach was used for political purposes. In the words of the committee chairman: "From a political perspective, Hogg's refusal to appear before us was of course delicate. One can only speculate whether a judicial recourse against this refusal would have been successful. But the threat to bring this case before the Court of Justice naturally was a political weapon. There was a crisis regarding BSE and the UK simply refused to give account for its actions regarding BSE." 317

If Hogg's refusal to appear before the BSE committee cannot be qualified as a breach of the Interinstitutional Agreement, the question arises whether it can be interpreted as a breach of the duty of sincere cooperation ex Article 4 (3) TFEU. The answer is again negative. Although demonstrating a persistently uncooperative attitude towards a committee of inquiry and a total lack of cooperation on the part of EU authorities or Member States clearly is in breach of Article 4 (3) TFEU, the duty of sincere cooperation cannot in itself give rise to a right to summon national ministers. ${ }^{318} \mathrm{~A}$ total refusal to designate officials and servants to the BSE committee would clearly imply a breach of the duty of sincere cooperation. This was, however, not the case, as the United Kingdom designated the Permanent Secretary from the Ministry of Agriculture in the minister's place.

The committee made full use of the ability to invite 'any other person to give evidence before it' on the basis of Article 3 (8) IIA. None of the witnesses invited from this category refused the invitation to testify. ${ }^{319}$ The testimonies of the various experts in the field of BSE gave the committee a sound understanding of the subject matter. This enabled the committee to pose pertinent questions to those being held to account, which in turn helped the committee to assess the conduct of the various persons involved thoroughly and to draw solid conclusions.

\section{Fact-finding visit to the UK}

In addition to its efforts to gather oral and written evidence, the committee carried out a three-day fact-finding visit to the UK in December 1996. The purpose of the visit was to obtain an on-the-spot picture of the implementation of veterinary measures against BSE. The opportunity was also taken to hold talks with representatives of the local veterinary authorities, the agricultural and consumer protection associations and the British Ministry of Agriculture. The committee's delegation discovered that the measures were being implemented satisfactorily, which demonstrated that such measures actually can be implemented in practice. This finding was significant because during its hearings the committee established that many measures were initially implemented and monitored inadequately in the UK. ${ }^{320}$ This fact-finding visit thus proved its value in the course of the inquiry.

\footnotetext{
317 Interview with Reimer Böge, 21 June 2011.

318 Cf. Section 2.3.5.

319 Shackleton (1998), p. 121.

320 European Parliament (1997). BSE committee. Report on alleged contraventions or maladministration in the implementation of Community law in relation to BSE (Part B, A40020/97/B, 7.2.1997), pp. 16-20.
} 


\section{Committee's efforts to cope with its limited legal position}

The BSE committee conducted its inquiry within the same legal framework as the Transit committee. Like the Transit committee, it had limited resources at its disposal: it did not have direct access to outside expertise in the form of specialist advisers and it depended on a small secretariat, including three administrators drawn temporarily from other parliamentary committees but who did not work on a full-time basis for the BSE committee. Chairman Böge observed: “Compared to the present-day's secretariats of temporary committees, we had a rather small secretariat. I had to read dossiers in a foreign language, because they were only available in French. I had to use a dictionary to look up the technical terms. We thus tried to make the best out of it, but the limited resources did not make it any easier for us". ${ }^{321}$

The committee further had no special budget to pursue its inquiries and it was subject to the same rules as standing committees for visits outside the three places of work. On the other hand, as was the case for the Transit inquiry, the committee's work was given high priority in the provision of technical services, such as translation, interpretation, printing and meeting rooms. ${ }^{322}$

Aware of its formally limited position and the limited resources available, the committee had to seek innovative solutions. Shackleton notes that the BSE committee chose to cope with its limited formal position in a similar way to the Transit committee, namely by using the public character of the inquiry as a tool to make witnesses aware that they would be held to account by a wider audience than the one to which they gave evidence. Therefore, the committee published its evidence, inter alia by placing it on the internet. ${ }^{323}$ With several hundred articles appearing in the press of all Member States of the European Union, the inquiry further generated significant media coverage. ${ }^{324}$ The particular sensitivity of the German public to the health aspects of the inquiry and the fact that the committee was chaired by the German MEP Reimer Böge ensured substantial coverage in Germany. ${ }^{925}$ Mann signalized during the inquiry that the publicity was successful: "there is $[\ldots]$ no doubt that the publicity generated by the committee has begun to seep through into the Union's overall approach to food policy-making". ${ }^{296}$ According to Böge, it was mainly the topic of the inquiry which accounted for the publicity: "In general, Europe does not have one public sphere, but in this case it was different. There was a common sensitivity for consumers across Europe. The BSE crisis was a classic example of a cross-border issue, which is not always the case in Europe.

\footnotetext{
321 Interview with Reimer Böge, 21 June 2011.

322 Shackleton (1998), p. 118.

323 Shackleton (1998), p. 123.

324. In some countries individual journalists decided to follow the committee throughout its work and became involved in doing extra research of their own. This was true, for example, of Jean Quatremer in the French paper Libération and André Riche in the Belgian francophone paper Le Soir, both of whom wrote numerous articles which were specifically concerned to identify the role of the Commission in policy-making relating to BSE. Cf. Shackleton (1998), p. 124.

325 Cf. Shackleton (1998), p. 124.

${ }^{326}$ Mann (1997).
} 
The fact that the inquiry attracted public interest across Europe is exactly the reason why we gathered so much relevant information”. 327

Notwithstanding its innovative responses to its limited formal position, the committee did not succeed in overcoming all of the formal restraints. Article 3 (4) IIA states that the authorities of the Member States and the institutions or bodies of the European Communities shall provide a committee of inquiry, where it so requests or on their own initiative, with the documents necessary for the performance of its duties. Committees of inquiry, however, lack a right to seize files to prevent the authorities under investigation from concealing incriminating information. ${ }^{328}$ In practice this means that the authorities under investigation are in the strong position of being able to decide which documents they forward to committees of inquiry, and when they do so. The limited position of committees of inquiry with respect to access to documents was felt by the BSE committee when the UK government refused to forward documents to it. ${ }^{329}$ As a consequence, the committee felt "severely hampered" in its efforts to clarify responsibilities for the BSE crisis. ${ }^{330}$ The fact that officials gave evidence not as individuals but on behalf of their institutions, acting in accordance with prior instructions from the institutions, as laid down in Article 3 (3) IIA, presented a further obstacle to the work of the committee. According to the committee, the Commission had employed this provision to conceal the truth from the committee on various sensitive issues. ${ }^{331}$ Furthermore, the committee found that the deadline for the submission of the report, as laid down in Article 2 (4) IIA, was, willingly or unwillingly, used against the BSE committee by the Commission and the UK government. The Commission delivered written replies extremely slowly, and the BSE committee accused the UK government of using blocking tactics from the moment its Minister for Agriculture refused to appear before the committee. As a consequence, these blocking tactics and the need for the committee to complete its work within the deadline laid down meant that a number of questions remained unanswered. ${ }^{332}$ The committee concluded: "The pressure of time and the wording of the 1995 Interinstitutional Agreement made it impossible to attribute individual responsibility for maladministration. The Committee of Inquiry confined itself to the institutional framework, although it remains aware that, in addition to political responsibilities, there may also be administrative responsibilities which can be attributed to individuals who work and hold or have held office in the various institutions". ${ }^{333}$

It seems, however, that things were slightly different in reality. It was not the committee's limited formal powers but rather the unwillingness of some members of the BSE committee that accounted for the BSE committee not

\footnotetext{
327 Interview with Reimer Böge, 21 June 2011.

328 Cf. Section 2.4.4.3.

329 European Parliament (1997). BSE committee. Report on alleged contraventions or maladministration in the implementation of Community law in relation to BSE (Part AI and AII, A4-0020/97/A, 7.2.1997), p. 14.

330 Ibid. p. 14.

331 Ibid. p. 36.

332 Ibid. p. 5.

333 Ibid. p. 5.
} 
attributing individual responsibility for maladministration. Chairman Böge described a dichotomy within the BSE committee between, on the one hand, those who thought 'institutionally' and who wanted to assess the actions of the institutions without blaming individuals within these institutions, and, on the other hand, those who actually did want to attribute individual responsibility to single persons working within the institutions. ${ }^{334}$ The text cited above apparently reflects the ultimate compromise between these two camps within the committee.

In one case, the committee was hampered by an Interinstitutional Agreement provision without recognizing that itself. Since the committee interpreted Article 3 (2) IIA as a right to summon national ministers, it blamed the UK Minister of Agriculture for his refusal to testify. However, as discussed above, the committee interpreted this provision falsely, since national ministers are under no formal obligation to accept an invitation to appear before a committee of inquiry. Hence, not the UK minister, but the limited legal provision was to blame. It is not unlikely that the existence of a formal obligation to appear would have lead to the attendance of the UK minister. In that case, the Commission would at least have taken into consideration the committee's recommendation of instituting proceedings against the United Kingdom before the European Court of Justice on account of the UK Minister's refusal to appear before the committee of inquiry. ${ }^{335}$

\subsubsection{The committee's final report}

The BSE committee adopted its final report on 7 February 1997.336 The following discussion of the report follows its structure: (I) conclusions and responsibilities, (II) recommendations for the future, and (III) the minority opinions of committee members.

\section{Conclusions and responsibilities}

In the first section of its report, the BSE committee draws conclusions on the responsibilities of the United Kingdom, the Council and the Commission. ${ }^{337}$ The committee blamed the UK government for its attitude concerning the BSE problem. The UK had failed to ensure the proper application of legislative measures in the field of BSE and it had not carried out the necessary checks. The BSE committee went on to say that, "doubtless under pressure of the meat industry”, the UK government had exerted pressure on the Commission's veterinary services with the objective of keeping the matter within the national orbit, thus avoiding Community inspections and preventing publicizing the extent of the epidemic, since this would have provoked unilateral action by

\footnotetext{
394 Interview with Reimer Böge, 21 June 2011.

335 Cf. European Parliament (1997). BSE follow-up committee. Report on the European Commission's follow-up of the recommendations made by the committee of inquiry into BSE (A4-0362/97, 14.11.1997), p. 46.

336 European Parliament (1997). BSE committee. Report on alleged contraventions or maladministration in the implementation of Community law in relation to BSE (Part AI and AII, A4-0020/97/A, 7.2.1997).

337 Ibid. pp. 4-37.
} 
some Member States on public health grounds. ${ }^{338}$ The committee revealed several breaches of the principle duty of sincere cooperation. ${ }^{339}$ The refusal by the UK Minister of Agriculture to give evidence before the committee was qualified as a breach by the UK government of the Member States' obligations under Article 3 (2) IIA. The UK government was furthermore criticized for its unwillingness to release documents, which "severely hampered" the work of the committee. ${ }^{340}$ The committee finally concluded that the successive British governments refused "to 'play the game' of proper and transparent cooperation which must govern relations between the Member States of the European Union, even beyond the terms of the Treaty". ${ }^{34.1}$

The Council was criticized as well, since it shared responsibility for the inaction and delays in connection with the control of the epidemic in the UK, the wrong decisions and poor coordination concerning health protection, and the disinformation supplied to the public. ${ }^{342}$ The committee furthermore concluded that the Council had failed to take effective steps to enforce export bans and control measures and it criticized the Council for giving political priority to economic interests of the meat industry over health protection. ${ }^{343}$

A large amount of blame was ultimately apportioned to the Commission for its management of the BSE crisis. Although the Commission had sufficient legal instruments available to adopt the measures necessary for the protection of public health from potential risks arising from animal epidemics, it failed to use these means to take the most stringent precautionary measures required. ${ }^{344}$ The committee revealed that the Commission had given priority to the management of the market, as opposed to the possible human health risks. ${ }^{345}$ From 1990 to 1994, when the outbreak had reached crisis levels, the Commission had followed a policy of downplaying the problem and of disseminating disinformation due to its interest in minimizing the public debate in order to avoid disrupting the beef market. This policy had not, however, been confined to avoiding publicity for the BSE issue, but had also played a major role in relations both among the Community institutions themselves (legislative activity on BSE by the Community had been suspended and no debates on BSE were held in the Council) and with the Member States (the then Commissioner for Agriculture, MacSharry, had in 1990 prevented both France and Germany from restricting the import of British beef by threatening them with Court proceedings). ${ }^{346}$ Moreover, due to the large number of British officials present in the two scientific committees operating in the field of BSE, the Commission had, instead of being instructed in an objective and impartial manner, been strongly influenced by 'British

\footnotetext{
398 Ibid. p. 15.

339 Ibid. pp. 6-13.

340 Ibid. p. 14.

341 Ibid. p. 15.

342 Ibid. p. 18.

343 Ibid. p. 18.

344 Ibid. p. 35.

345 Ibid. p. 22.

${ }^{346}$ Cf. Ibid. pp. 22-37; Vos (2000), p. 232.
} 
thinking' ${ }^{347}$ In addition, the committee concluded that there had been a lack of coordination and cooperation between the various Directorate-Generals of the Commission and the relevant scientific committees operating in the field of BSE. ${ }^{348}$ Lastly, the committee condemned the Commission for its obstructive attitude in the course of the inquiry. The committee accused the Commission of employing Article 3 (3) IIA, which stipulates that officials speak on behalf of their institution, to conceal the truth from the committee. The obstructive attitude of the Commission shed doubt on the reliability of other Commission testimonies, but the committee was not able to substantiate this within the framework of the Interinstitutional Agreement. The committee thus observed that the Commission's attitude undermined the Parliament's capacity for investigation, contrary to the spirit of the Interinstitutional Agreement. In the light of these circumstances, the committee emphasized the necessity of revising the provisions of the Interinstitutional Agreement. ${ }^{349}$ After the inquiry, the committee chairman, Reimer Böge, sent an internal document to the members of the European Parliament in which he put forward suggestions on how to modify the right of inquiry. Section 2.5.2.5 discusses this internal document.

\section{(II) Recommendations for the future}

The second section of the report sets out recommendations for the future. ${ }^{350}$ The committee considered that "measures must be taken in response to the BSE crisis and the serious failings on the part of the Commission and the United Kingdom, in such a way as to bring about tangible changes for the future". ${ }^{351}$ In line with this, the BSE committee included over 70 recommendations in its final report. The committee urged the Commission to assume its political responsibilities and to take an active part in the implementation of the recommendations. It called upon the Parliament to be meticulous in scrutinizing the Commission's follow-up on the recommendations. ${ }^{352}$ In compliance with its brief, the committee made recommendations mainly on the following aspects:

“- the transparency of the action to combat BSE through the widest possible dissemination of relevant research data and findings,

- the procedures for monitoring to combat BSE and protect public health and animal health,

- the adoption of all relevant measures for the protection of public health,

- the adoption of measures to restore the smooth operation of the markets,

347 European Parliament (1997). BSE committee. Report on alleged contraventions or maladministration in the implementation of Community law in relation to BSE (Part AI and AII, A4-0020/97/A, 7.2.1997), p. 10.

$348 \mathrm{Ibid}$. pp. 24 and further.

${ }^{349}$ Ibid. p. 36.

350 Ibid. pp. 38-48.

${ }^{351}$ Ibid. p. 37.

352 Ibid. p. 37. 
- the adoption of measures corresponding to responsibilities identified by the present committee of inquiry". ${ }^{353}$

Concerning the third category, the adoption of all relevant measures for the protection of public health, the Parliament urged the Commission to call, together with the Parliament, for another decision-making procedure to be used for agricultural matters. In order to give the Parliament a stronger position in decision-making in these matters, the Parliament recommended replacing the consultation procedure with the co-decision procedure. ${ }^{354}$

Concerning the last category, the adoption of measures corresponding to responsibilities identified by the BSE committee, the committee voiced its conviction that those responsible should be condemned for the errors they had committed. The committee urged the Commission to take disciplinary action against those officials who failed to carry out their duties in the BSE matter. ${ }^{355}$ The committee further called upon the Commission to bring administrative proceedings against the UK to secure repayment of all sums allocated for the purposes of eradicating BSE. In addition, it recommended that the Commission launch infringement proceedings against the Member States which had not fulfilled their obligations under the Treaty. In particular, the committee recommended that the Parliament call upon the Commission to start such proceedings against the United Kingdom on account of the failure the UK Minister of Agriculture to appear before the committee of inquiry. ${ }^{356}$ Furthermore, the committee called on the Commission to propose an amendment to the Treaty enabling a motion of censure to be tabled against individual members of the Commission. ${ }^{357}$

Finally, the BSE committee finally addressed a recommendation to the European Parliament in rather general terms concerning the general position of committees of inquiry: "In the course of this temporary committee of inquiry's work, cooperation with the witnesses called has not always been as good as it should have been. On the basis of this experience, the Committee of Inquiry recommends that Parliament examine whether the legal basis provided by Article $138 \mathrm{c}$ of the Treaty (now Article 226 TFEU, CNS) and/or the provisions of Decision 95/167 [...] (the Interinstitutional Agreement, CNS) are sufficient and adequate for making the best use of that right and, if necessary, propose initiatives for extending Parliament's scope for taking action”. ${ }^{358}$

(III) Minority opinions

Seven members of the BSE committee delivered a minority opinion to the committee report. ${ }^{359}$

\footnotetext{
353 Ibid. p. 38.

354 Ibid. p. 42.

355 Ibid. p. 36.

356 Ibid. p. 46.

357 Ibid. p. 46.

358 Ibid. p. 48.

359 These minority opinions are published separately in Part AIII of the Final Report: European Parliament (1997). BSE committee. Report on alleged contraventions or
} 
Four committee members expressed their will to table a motion of censure against the Commission in accordance with Article 144 EC Treaty (at present: Article 234 TFEU). ${ }^{360}$ One of them, Jean-Claude Martinez, pointed out that the rapporteur of the BSE committee, Manuel Medina Ortega, "wished it to be thought that it was legally impossible" to censure the Commission because (1) only two Commissioners were responsible, and (2) that they were no longer in office. ${ }^{361}$ Martinez subsequently correctly explained the theory of the motion of censure. With regard to the first objection, he stated: "As regards the individual responsibility of the Commissioners Mr. MacSharry and Mr. Steicher, this distinction is based on confusion between civil and criminal liability, which can clearly only be individual, and the political responsibility of a collective body, which, equally clearly, can only be collective". ${ }^{362}$ As regards the second objection, that the Commission could not be censured because the responsible Commissioners were no longer in office, Martinez pointed out: "this runs counter to the basic principle of the continuity of institutions. In legal terms, the Santer Commission is not an institutionally different 'species' from the Delors Commission, it is the continuity of a single institutional 'species': the Brussels Commission as referred to in the Treaty of Rome and Maastricht Treaty. The political responsibility cannot be attributed intuitue personae' to its component members, but instead the institution which they serve". ${ }^{363}$

José Happart (PES) discussed in his minority opinion the Council's and Commission's "blatant lack of cooperation" with the BSE committee throughout the inquiry. He deplored the fact that most information and "revealing" documents reached the committee by means of leaks or from information provided by journalists via the media. ${ }^{364}$

\subsubsection{Chairman's evaluation of the committee's working methods}

Like the chairman of the Transit committee did for his committee, the chair of the BSE committee presented his observations on the working methods of the BSE committee in an internal document to the members of the European Parliament. ${ }^{365}$ This document was submitted to Parliament on 7 January 1997. Chairman Böge discussed three issues concerning the right of inquiry which he considered problematic: (1) access to documents, (2) the invitation of witnesses, and (3) the powers vis-à-vis witnesses who testify before a committee of inquiry.

maladministration in the implementation of Community law in relation to BSE (Part AIII, A4-0020/97/AIII, 7.2.1997).

360 Cf. European Parliament (1997). BSE committee. Report on alleged contraventions or maladministration in the implementation of Community law in relation to BSE (Part AIII, A4-0020/97/AIII, 7.2.1997); These MEPs were: Christine Barthet-Mayer (p. 3), José Happart (p. 6), Jean-Claude Martinez (p. 10) and Édouard des Places (p. 16).

361 Ibid. p. 10.

362 Ibid.p. 10.

363 Ibid.pp. 10-11.

364 Ibid.p. 5.

365 European Parliament (1997). BSE committee. Chairman's observations on institutional aspects of the work of the committee of inquiry (PE 220.853, 7.1.1997). 


\section{(1) Access to documents}

The right to require documents was considered problematic since a committee of inquiry lacks a right to seize files to prevent the authorities under investigation from concealing incriminating information. Böge observed: "any document forwarded to us by the Council, Commission or national authorities has already been scrutinized by those whose actions the committee is supposed to be scrutinizing. There is therefore much less likelihood of discovering omissions on the part of the authorities under investigation". ${ }^{366}$

Böge noted that the Commission and the Council were cooperative in the sense that they forwarded documents to the committee upon the latter's request. However, national authorities and Community institutions only inadequately fulfilled their duty to provide the committee with the documents necessary for the performance of its duties on their own initiative as the BSE committee usually had to take the initiative itself and request the documents it needed. ${ }^{367}$

\section{(2) Invitation of ritnesses}

Another constraint was the lack of means to compel persons to appear before a committee of inquiry. As a consequence thereof, the BSE committee could not hear the UK Minister of Agriculture, which made it "much harder for it to trace the chain of responsibility from the officials responsible for implementation back to those at the top with political responsibility". ${ }^{368}$ Böge observed that the Commission and the Council were cooperative in the sense that they made themselves available to testify before the committee. ${ }^{369}$

\section{(3) Powers vis-à-vis witnesses}

The third problematic issue was the lack of a right to put witnesses under oath to tell the truth and the lack of penalties in case of false testimony. Chairman Böge observed that the absence of such rights made it very difficult to discover possible irregularities by hearing evidence from those concerned. ${ }^{370}$

Böge recommended the following amendments with regard to the three problematic issues:

- "A European Parliament committee of inquiry must have a right to autonomous inspection of files. It must - like an investigating magistrate - be able to seize files from the Commission, Council and, where necessary, national administrations. In doing so, the Committee must confine itself to what is necessary for the performance of its duties, as defined in the mandate conferred to it by the European Parliament.

- A European Parliament committee of inquiry must have the right to summon witnesses. If witnesses fail to comply with a summons, it must be possible to bring about their appearance through the threat and/or imposition of penalties (fines).

\footnotetext{
366 Ibid. p. 2 .

367 Ibid. p. 3.

${ }^{368}$ Ibid. p. 2

369 Ibid. p. 3.

${ }^{370}$ Ibid. p. 2.
} 
- A European Parliament committee of inquiry must have the right to swear in witnesses. It must be possible to prosecute witnesses if they give false testimony." 371

When comparing these proposals to the recommendations of the chairman of the Transit committee, it is striking that both chairmen had fundamentally different views on the future of the right of inquiry. Whereas the German MEP Reimer Böge proposed equipping inquiry committees with strong formal powers, the British MEP Tomlinson mainly came up with recommendations on the working methods of inquiry committees. ${ }^{372}$ Böge considered it necessary to amend the Interinstitutional Agreement in order to turn the relatively limited committees of inquiry into powerful committees equipped with a right to autonomous inspection of files, a right of summons, a right to swear in witnesses and a right to penalize witnesses in the event of their refusal to cooperate in the course of the inquiry. Tomlinson mainly advised the Parliament on how to proceed within the existing legal framework by using informal mechanisms, such as how to cross-examine witnesses and how to organize the work so as to maximize the credibility of the evidence and to minimize the opportunities for witnesses to weaken the impact of an inquiry. Interestingly, Reimer Böge seems to have adjusted his opinion on this issue somewhat since 1997, as he observed in 2011: "On the basis of experience I believe that it is particularly important to attract wide publicity for an inquiry. The wide interest of the public and the media for the BSE issue made the BSE inquiry a successful inquiry. Of course you can try to strengthen the provisions governing the right of inquiry. However, I believe that the degree of interest of the public and the media for an inquiry is at least as important as strong investigative powers on the part of inquiry committees". ${ }^{373}$

\subsubsection{Plenary debate of 18 February 1997}

On 18 February 1997, the final report of the BSE committee was debated in plenary session with representatives of the Commission, including its President, Jacques Santer and the two responsible Commissioners: Emma Bonino (Health and Consumer Protection) and Franz Fischler (Agriculture and Rural Development). ${ }^{374}$ The Parliament was indignant at the fact that the Council's Presidency - as one of the actors responsible for the BSE crisis - was absent during the plenary debate.

The chairman of the BSE committee, Böge, observed in his speech that despite the limited right of inquiry, the Parliament had proved to be in a position to use the right of inquiry as an instrument of control at any time and that it could be applied in other cases as well. He pointed out that Parliament could only succeed in restoring the damaged confidence of citizens by completely

\footnotetext{
371 Ibid. p. 3.

372 Cf. Section 2.5.1.4.

${ }^{373}$ Interview with Reimer Böge, 21 June 2011.

374 The literal transcripts of the plenary debate of 18 February 1997 are available online under:

http://www.europarl.europa.eu/calendar/calendar?APP=DEBATS\&LANGUE=EN (click on '18 February 1997' and subsequently on 'BSE').
} 
clarifying matters, establishing where responsibility lies and drawing the necessary political conclusions. Böge suggested in his final sentences that the Commission should be given "an opportunity to improve matters". However, he clarified that if things were not changed satisfactorily, a motion of censure would be tabled. At that time, José Happart (PES) had already tabled a motion of censure against the Commission.

The President of the Commission, Jacques Santer, apparently driven by a fear of being censured, responded promptly to the respective speeches by announcing actions in the following areas: the administrative structure of the Commission, the system of scientific consultation, the decision-making procedures, the control mechanisms, and the Community legal bases.

Although the plenum concentrated mainly on the Commission, it acknowledged that the largest portion of the blame was to be attributed to an executive actor which it had almost no formal powers over: the UK government. Charles Goerens (ELDR) remarked: "as everyone knows, the villain of the piece is first and foremost a national government over which we have no say. That government $[\ldots]$ should celebrate the fact that it is the Commission that is in the dock, whilst its own clearly documented crimes are quietly forgotten”. The UK government was blamed even more when Pauline Green (PSE) informed the Parliament that the then British Prime Minister, John Major, had referred to the final report of the BSE committee as a "load of tosh". Green explained: "for those of you who do not know that word, it means complete and utter rubbish. So the British Prime Minister considers the report we are discussing this afternoon to be a load of rubbish". Böge reacted directly: "let me avoid using an agricultural expression, since this word rubbish refers to our specific findings. One of the expectations of the European public is indeed that we should make progress with the major goals of European integration, but another is that, where necessary, we should take our pitchfork and clear out the stable". The reaction of Johannes Voggenhuber (Greens) was even more direct: "in view of the comments which have just been quoted, one can only hope that the Prime Minister's political career will one day be buried underneath this rubbish". Macartney (ARE) joked that the British Government's interpretation of BSE was "Blame Someone Else".

\section{Parliamentary resolution on the results of the BSE committee}

On 19 February 1997, one day after the debate, the Parliament approved the BSE committee's report (with 422 in favour, 49 against, and 48 abstentions) and it adopted a resolution calling on the Commission to take urgent and effective action to follow up on the recommendations in the report and to implement the legislative, organizational and personnel measures therein without delay, and to draw up a report for the European Parliament. ${ }^{375}$ The Parliament furthermore authorized its President to instruct its committees responsible for each aspect to verify the actions taken by the Commission on the recommendations of the BSE committee.

\footnotetext{
375 Resolution on the results of the Temporary Committee of Inquiry into BSE (OJ C 85, 17.03.1997, p. 61).
} 
According to Böge, the end of the inquiry by no means implied the end of parliamentary interest in the BSE issue: "There was a sense within the Parliament that we were not satisfied with the mere establishment of mismanagement. We wanted to achieve qualitative changes. That's when we asked ourselves: how can we put pressure on the Commission to enforce such changes? We decided to maximize the pressure on the Commission by saying: Commission, you should take your responsibilities and come up with improvements. If not, we can tell you right away that the Parliament will adopt a motion of censure at the end of this year". ${ }^{376}$

The Parliament thus threatened to table a motion of censure against the Commission if the recommendations were not carried out within a reasonable timeframe, in any event by November 1997. ${ }^{377}$ This threat, a novel invention of Parliament, became known as a 'conditional motion of censure'. Chambers observed that this novelty followed in the "European Parliament's tradition of exploiting new methods to gain influence". ${ }^{378}$

Furthermore, the Parliament expressed its frustration at the lack of cooperation by executive actors involved by calling for a reconsideration of the Interinstitutional Agreement with a view to including a sanction mechanism for Member States or institutions refusing to cooperate in the work of an inquiry. ${ }^{379}$

In keeping with the stipulation in Article 144 EC Treaty (at present: Article 234 TFEU) that the Parliament shall not vote on a motion of censure on the Commission within three days after the motion has been tabled, the Parliament voted on 20 February 1997 on the motion of censure as tabled on 17 February 1997 by José Happart (PES). The motion of censure was, however, rejected.

\subsubsection{Follow-up to the inquiry}

Directly after the BSE inquiry, the Parliament set up a temporary BSE followup committee to monitor the action taken by the Commission on the recommendations made by the committee of inquiry into BSE. This follow-up committee was instructed to adopt a report before the first part-session in November 1997. ${ }^{380}$ Section 3.6.1 discusses the work of this committee, which was not a temporary committee of inquiry but a 'temporary special committee'. This section is restricted to considering the impact the inquiry into the BSE crisis has had.

It can be concluded that the BSE committee has had a substantial impact. Shackleton observes that the inquiry was successful since it, like the Transit inquiry, provoked changes in Community policy which would almost certainly not have taken place had the inquiry not been conducted. These changes were

376 Interview with Reimer Böge, 21 June 2011.

377 Resolution on the results of the Temporary Committee of Inquiry into BSE (OJ C 85, 17.03.1997, p. 61).

378 Chambers (1999), p. 96.

379 Resolution on the results of the Temporary Committee of Inquiry into BSE (OJ C 85, 17.03.1997, p. 61).

380 Decision on the setting up of a temporary committee instructed to monitor the action taken on the recommendations made concerning BSE (OJ C 150, 19.5.1997, p. 9). 
not restricted to the limited domain of BSE, but the inquiry led to changes in a much broader territory: the future shape of the Common Agricultural Policy. ${ }^{381}$ Chambers uses mythological terms: "if the work of the BSE Inquiry and 'follow-up' committee can be likened to the Labours of Hercules, then we could say that it has had the effect of diverting a river through the Augean Stables of the Commission's veterinary services and the 'Stygian morass' of comitology". ${ }^{382}$

Additionally, without having strong inquiry powers at its disposal, the Parliament demonstrated how the right of inquiry can be exercised in conjunction with its other powers to bring about changes. ${ }^{383}$ The threat of a motion of censure combined with the setting up of a temporary committee to closely scrutinize the Commission's follow-up to the BSE inquiry made it virtually impossible for the Commission to escape accountability. In this manner, the Parliament managed to 'turn the screws' on the Commission's action in this area as never seen before. ${ }^{384}$ Westlake notes that the conditional vote of no confidence "provided an elegant and ingenious means for the Parliament to ward off constitutional crises whilst retaining a close hold on the Commission. These developments displayed Parliament's political and constitutional maturity and further consolidated the sea-change which has been occurring in Commission-Parliament relations since 1979". .85

However, critical comments can be made as well. Although it held a variety of executive actors responsible (Commission, Council and the UK), the BSE committee solely managed to hold the Commission to account. Former President of the European Parliament, Klaus Hänsch, remarked that the BSE inquiry showed how growing parliamentary control of the Commission can sometimes have the perverse effect of creating mismatches between power and responsibility in the political system of the European Union. The Commission was the only body that the Parliament could hold to account for the handling of the BSE outbreak, although it was not the only body that was responsible for the problem. ${ }^{986}$ Notwithstanding the fact that committees of inquiry only have limited powers vis-à-vis the Council and Member States, this criticism could have been avoided at least partly. Parallel to the BSE inquiry by the European Parliament, the UK government had set up a national, quasi-judicial, inquiry on BSE. 887 There was, however, no collaboration between the European and the UK inquiry committees. This was a missed opportunity for both of them. The BSE committee of the European Parliament would have had access to the evidence of UK ministers and the UK committee would have been informed better on European aspects. ${ }^{388}$ Close cooperation could, at least

\footnotetext{
381 Shackleton (1998), p. 125.

382 Chambers (1999), p. 105.

383 Cf. Shackleton (1998), p. 125.

384. Cf. Chambers (1999), p. 106.

385 Westlake (1997), p. 26.

386 Klaus Hänsch, cited in: Lord (2001), p. 652. See also: Wiersma (2004), p. 227.

387 The so-called 'Phillips Inquiry', set up by the Secretary of State for Agriculture in December 1997 and chaired by a judge. Its report is online available under: http://www.bseinquiry.gov.uk/.

${ }_{388}$ Cf. Harlow (2002), p. 100.
} 
partly, have compensated for the damage suffered by the BSE committee from the limited cooperation on the part of the UK government with the inquiry.

All in all, the European Parliament demonstrated in the case of BSE that, despite formal constraints, it managed to hold the Commission to account and showed that it can have a significant impact on the Commission's exercise of its powers. However, due to its main focus on the Commission, the Parliament was not able to hold the Council and the UK government to account for their responsibilities.

\subsubsection{Inquiry into the crisis of the Equitable Life Assurance Society}

\subsubsection{Subject, establishment and duration of the inquiry}

About ten years after the committees of inquiry into Transit and BSE, the Parliament decided to set up a committee of inquiry into the crisis of the Equitable Life Assurance Society at its plenary session of 18 January 2006. ${ }^{389}$

\section{Background information on the inquiry subject}

The Equitable Life Assurance Society (hereafter: Equitable Life) is a British life insurance company. Part of Equitable Life's range of services includes selling 'annuities' to individuals. An annuity is an insurance product that provides a series of periodic payments that are guaranteed in terms of amount and payment period. If a person chooses to take the annuity payments over his or her lifetime, the person will have a guaranteed source of income until his or her death. If the person dies younger than their life expectancy, he or she will get back from the insurer far less than was paid in. On the other hand, if he or she outlives their life expectancy, the person might get back far more than the cost of the annuity plus earnings. ${ }^{390}$

During the 1950s, Equitable Life began selling such Guaranteed Annuity Rates, the so-called GARs. Offering a guaranteed pension for life involves predicting how long a person will live and predicting interest rates for up to forty years into the future. Equitable Life did not correctly predict the increase in the life expectancy of the general population and the historical fall in interest rates. As a consequence, a time-bomb started ticking at the moment GARs were introduced. ${ }^{391}$ The management of Equitable Life realized this and decided subsequently to pay newly retired people less than the guaranteed amount. This was directly challenged in court by some of the policyholders affected. After a long legal battle, the UK House of Lords ruled that Equitable Life's approach was inappropriate and that it must meet its obligations to its GAR policyholders. As a result, the financial situation of Equitable Life worsened. In 2000 Equitable Life closed its doors to new business and a new board was appointed. In 2001, the new board cut all pension policy values by $16 \%$ (14\% for life policies). ${ }^{392}$ According to some estimates, 1.7 million

389 Decision of 18 January 2006 on setting up a Committee of Inquiry into the crisis of the Equitable Life Assurance Society (OJ L 186, 7.7.2006, pp. 58-59).

390 European Parliament (2007). Equitable Life committee. Report on the crisis of the Equitable Life Assurance Society. Final Report (A6-0203/2007, 23.5.2007), p. 18.

391 Ibid. p. 17.

392 Ibid. p. 17. 
policyholders were affected by this policy cut. It was estimated that some 15000 policies had been sold in Germany, Ireland and other non-UK Member States at the time of Equitable Life's closure to new business.

In the face of these developments, several investigations at the UK level started one after the other, of which two deserve particular mention: the investigation by the UK Parliamentary Ombudsman and the Penrose inquiry ${ }^{393}$. The UK Parliamentary Ombudsman concluded in June 2003 that prudential regulators were not guilty of maladministration. The Penrose report, which was published in March 2004, stated in essence that, despite having identified some serious regulatory failings in the way the firm was supervised, the balance of blame lay more with Equitable Life's management than with the regulators. ${ }^{394}$

In 2004, the first petitions on the case reached the European Parliament's committee on Petitions. The British, German and Irish petitioners argued that UK regulators had failed to supervise adequately the ability of Equitable Life to meet its regulatory financial requirements and that the actions and omissions of the past regulators were in breach of UK rules and the corresponding EU life insurance Directives. ${ }^{395}$

In order to understand the case, it is important to mention the central Directive in this matter: the Third Life Directive (Directive 92/96/EEC) on the coordination of laws, regulations and administrative provisions relating to direct life assurance. The main aim of the directive is to enable an insurer with its head office in the EU (in this case: Equitable Life) to set up operations anywhere in the European Union.

\section{Equitable Life committee}

The petitions concerning Equitable Life led to the establishment of the third committee of inquiry, the Equitable Life committee, at the plenary session of 18 January 2006. ${ }^{396}$ The Equitable Life committee was composed of 22 full members and 15 substitutes. ${ }^{397}$ The committee started its work on 2 February 2006. The Irish MEP Mairead McGuinness (EPP-ED) was appointed as chair of the Equitable Life committee and the British MEP Diana Wallis (ALDE) as rapporteur.

The Parliament mandated the Equitable Life committee to "investigate alleged contraventions or maladministration in the application of Community law in relation to the crisis of Equitable Life, without prejudice to the jurisdiction of national or Community courts". ${ }^{398}$ In particular, the committee's investigation was to focus on four key issues: (1) investigation into alleged contraventions or

${ }_{393}$ The Penrose report is online available under:

http://www.hm-treasury.gov.uk/indrev_pen_index.htm.

394 European Parliament (2007). Equitable Life committee. Report on the crisis of the Equitable Life Assurance Society. Final Report (A6-0203/2007, 23.5.2007), p. 18.

395 Ibid. 18.

396 A timeline of relevant events with respect to Equitable Life is available online under: http://www.europarl.europa.eu/comparl/tempcom/equi/background/timeline_short_en.pd f.

397 European Parliament (2007). Equitable Life committee. Report on the crisis of the Equitable Life Assurance Society. Final Report (A6-0203/2007, 23.5.2007), p. 4.

398 Decision of 18 January 2006 on setting up a Committee of Inquiry into the crisis of the Equitable Life Assurance Society (OJ L 186, 7.7.2006, pp. 58-59). 
maladministration in the application of Directive 92/96/EEC by the UK, (2) Assessment of the UK regulatory regime in respect of Equitable Life, (3) the status of claims and adequacy of remedies available to policyholders, and (4) assessment of the Commission's monitoring of implementation. ${ }^{399}$ The Equitable Life committee was instructed to "make any proposals that it deemed necessary in this matter." 400

Campaigners from the Equitable Members' Action Group (EMAG) welcomed the inquiry. Paul Braithwaite, EMAG's general secretary, said it was encouraging news for long-suffering policyholders that the European Parliament was keen to take action and contrasted this with the British establishment, which had "spent six years sweeping it under the carpet". Braithwaite furthermore noted that the chairman of the standing committee on Petitions, Marcin Libicki (UEN), had indicated the European Parliament would seek to resolve the problem either through the ECJ or through a compromise with the UK government. ${ }^{401}$

The committee's initial mandate of twelve months was extended for a further three months in July 2006. ${ }^{402}$ On 8 May 2007, the Equitable Life committee presented its report. ${ }^{403}$

\subsubsection{Inquiry proceedings}

At the beginning of the committee's proceedings, rapporteur Wallis submitted to the committee members a working document, entitled 'Lines of action arising from the mandate for inquiry into the collapse of Equitable Life Assurance Society'. ${ }^{404}$ The document aimed to provide an approach to establishing the committee's main lines of investigation and to propose various forms of action.

\section{Working document of the committee's rapporteur}

In her working document, the rapporteur, Wallis, discussed for each of the four key points of the committee's mandate - as discussed above - exactly what had to be investigated and how it should be done. To that end, she formulated specific actions for every key point, such as who to invite to testify, what kind of questions to ask them, where to go for on-the-spot fact-finding visits, and which information to request from the executive actors involved. Wallis furthermore proposed distinguishing between, on the one hand, investigations 'at the Member State level' (the first three key points:

\footnotetext{
399 Cf. European Parliament (2007). Equitable Life committee. Report on the crisis of the Equitable Life Assurance Society. Final Report (A6-0203/2007, 23.5.2007), p. 11.

${ }_{400} \mathrm{Cf}$. Decision of 18 January 2006 on setting up a Committee of Inquiry into the crisis of the Equitable Life Assurance Society (OJ L 186, 7.7.2006, pp. 58-59).

401 Jones (2005).

402 European Parliament resolution of 4 July 2006 on the crisis of the Equitable Life Assurance Society (2006/2026(INI)).

${ }_{403}$ European Parliament (2007). Equitable Life committee. Report on the crisis of the Equitable Life Assurance Society. Final Report (A6-0203/2007, 23.5.2007).

${ }^{404}$ European Parliament (2006). Equitable Life Committee. Working document on lines of action arising from mandate for inquiry into the collapse of Equitable Life Assurance Society (2006/2026 (INI), 9.3.2006).
} 
transposition/implementation, (2) regulation/supervision and (3) redress mechanisms), and the question of the Commission's role on the other hand (key point 4). The four points were to be developed gradually through different in progress' working documents and an interim report on the investigations was to be put to the plenary before the summer of 2006. Finally, with regard to the first three key points, Wallis proposed using a comparative approach, including the UK, Germany, Ireland and the Netherlands or Spain. ${ }^{405}$

The approach with regard to the first three key points, as proposed by the rapporteur, Wallis, can be summarized as follows ${ }^{406}$ :

\begin{tabular}{|l|l|l|l|}
\hline $\begin{array}{l}\text { Key } \\
\text { point }\end{array}$ & Issue & Main question & $\begin{array}{l}\text { Member States to } \\
\text { be addressed } \\
\text { (comparative } \\
\text { approach) }\end{array}$ \\
\hline $\mathbf{1 .}$ & $\begin{array}{l}\text { Investigation into alleged } \\
\text { contraventions or } \\
\text { maladministration in the } \\
\text { application/implementation } \\
\text { of the Third Life Directive } \\
\text { by the UK }\end{array}$ & $\begin{array}{l}\text { How did you } \\
\text { implement? }\end{array}$ & $\begin{array}{l}\text { UK, } \\
\text { Ireland, } \\
\text { Spain/Netherlands }\end{array}$ \\
\hline $\mathbf{2 .}$ & $\begin{array}{l}\text { Assessment of UK } \\
\text { regulatory regime: adequacy } \\
\text { of the level of supervision, as } \\
\text { required by the Directive }\end{array}$ & $\begin{array}{l}\text { How did you or } \\
\text { would you have } \\
\text { regulated? }\end{array}$ & $\begin{array}{l}\text { UK, } \\
\text { Ireland, } \\
\text { Spain/Netherlands }\end{array}$ \\
\hline $\mathbf{3 .}$ & $\begin{array}{l}\text { Status of claims by non-UK } \\
\text { citizens and adequacy of } \\
\text { system of remedies for } \\
\text { prejudice available to } \\
\text { policyholders }\end{array}$ & $\begin{array}{l}\text { What } \\
\text { mechanisms } \\
\text { are/were } \\
\text { available to } \\
\text { claimants in } \\
\text { your country? }\end{array}$ & $\begin{array}{l}\text { Ireland, } \\
\text { Spain/Netherlands }\end{array}$ \\
\hline
\end{tabular}

On the basis of these three points, the Equitable Life committee could subsequently assess the Commission's monitoring of implementation (the fourth key point).

\section{Work of the committee}

During the inquiry, the committee assembled 17 times, held 11 public hearings, organized two workshops and sent two official delegations to Dublin and London for on-the-spot fact-finding visits. It heard oral evidence from 38 witnesses, analyzed 92 pieces of public written evidence, 33 pieces of filed written evidence (which were not posted on the committee website) and 32

${ }^{405}$ Ibid. p. 3.

${ }^{406}$ Cf. Ibid. p. 8. 
pieces of confidential evidence. The committee also commissioned three external expert studies. ${ }^{407}$

\section{Oral evidence}

In the course of its public hearings, the Equitable Life committee heard 38 witnesses, including Equitable Life policyholders from the UK, Ireland and Germany (of which some had previously petitioned the European Parliament). It also heard representatives of the UK, Irish, German and Swiss governments, representatives of the Commission, including the Irish Commissioner Charlie McCreevy (Internal Market), and it heard the chief executive of Equitable Life. ${ }^{408}$

In contrast with the inquiries into the Community Transit regime and into the BSE crisis, many witnesses who were invited to testify before the committee declined to attend. ${ }^{409}$ More than a third of the witnesses (20 out of 58 ) that had been invited refused to appear before the committee. This is a strikingly large number of refusals when compared to the other two inquiries. For the Transit inquiry, all 62 witnesses invited agreed to testify, while only one out of 34 persons invited refused to appear before the BSE inquiry committee (namely Douglas Hogg, the UK Minister of Agriculture).

As for the Transit and BSE inquiries, gaining the attendance of Commissioners and representatives of the Commission did not prove problematic, although a former Commissioner (Frits Bolkestein, Internal Market) was among those who refused to testify. The persons who refused to testify included three representatives of the UK Treasury (the UK's economics and finance ministry), two representatives of the Financial Service Authority (FSA), which is an independent UK government agency, the Irish Minister for Enterprise, Trade and Employment, two UK Members of Parliament, the UK Ombudsman, the Financial Services Ombudsman (FOS) and the Head of UK Parliamentary Ombudsman Investigations into Equitable Life, and 'private' persons, such as persons working in the field of assurances, journalists and Lord Penrose, a Scottish Judge who lead the Penrose Inquiry mentioned above. ${ }^{410}$

With regard to the UK Members of Parliament, the UK Ombudsman, the Financial Services Ombudsman (FOS) and the Head of UK Parliamentary Ombudsman Investigations into Equitable Life, it must be noted that a delegation of the committee met those persons on its fact-finding trip to London on 16 October 2006. ${ }^{411}$ The question arises whether there were persons who refused to testify in spite of a legal obligation to do so. Section 2.4.4.1 shows that there are three categories of witnesses in this respect: (1) members of an institution or a body of the European Communities or the

407 European Parliament (2007). Equitable Life committee. Report on the crisis of the Equitable Life Assurance Society. Final Report (A6-0203/2007, 23.5.2007), p. 4.

408 Ibid. pp. 20-22.

409 The final report contains a list of names: European Parliament (2007). Equitable Life committee. Report on the crisis of the Equitable Life Assurance Society. Final Report (A60203/2007, 23.5.2007), p. 22.

${ }^{410} C f$. European Parliament (2007). Equitable Life committee. Report on the crisis of the Equitable Life Assurance Society. Final Report (A6-0203/2007, 23.5.2007), p. 22.

${ }_{411}$ Ibid.p. 29. 
government of a Member State (Article 3 (2) IIA), (2) officials and servants (Article 3 (3) IIA), and (3) other persons. The latter is the residual category which includes all those who do not fall under the first two categories (Article 3 (8) IIA).

Witnesses of the first (except for Commissioners) and the third category are under no formal obligation to accept an invitation to testify before a committee of inquiry. As a consequence, the Irish Minister (first category), the UK Members of Parliament, the UK Ombudsman, the Financial Services Ombudsman (FOS), the Head of UK Parliamentary Ombudsman and the private persons (third category) could legally refuse to appear before the committee. The situation is somewhat different with regard to witnesses of the second category: the officials and servants. Committees of inquiry cannot enforce specific officials or servants to appear before them, but in response to a 'reasoned request' for such an official or servant to appear 'the Member States concerned and the institutions or bodies of the European Communities shall designate the official or servant whom they authorize to appear' (Article 3 (3) IIA). The UK, indeed, did not designate the three representatives of the UK Treasury and the two representatives of the Financial Service Authority (FSA) as requested by the Equitable Life committee. However, according to Article 3 (3) IIA, it is the Member State's decision whom to authorize to appear. The UK apparently did not authorize the appearance of these specific persons, but it authorized the attendance of three other witnesses who in fact did testify before the committee. ${ }^{412}$ Strictly speaking, the UK government thus complied with the terms of Article 3 (3) IIA and it thus can be concluded that none of the persons who refused to accept an invitation to appear before the committee acted in breach of the Interinstitutional Agreement.

One can only speculate what the UK government's reasons were for blocking the appearance of specific officials and servants, but it might very well be that the Equitable Life committee's decision to invite particular UK officials and servants was the problem. Perhaps the UK government would have designated these officials and servants had the committee not explicitly mentioned their names in the invitations.

\section{Written evidence}

The Equitable Life committee received 92 pieces of public written evidence, 33 pieces of filed written evidence, which were not posted on the website, and 32 pieces of confidential evidence. The pieces of evidence included various reports on the Equitable Life issue, such as the abovementioned Penrose report, the UK Parliamentary Ombudsman's report, and the answers of non-UK Equitable Life policyholders to a detailed questionnaire circulated by the Equitable Life committee.

Under the terms of Article 3 (4) IIA, the committee requested information from the Commission regarding the transposition and implementation of the Third

${ }_{412}$ The UK authorized the following three persons to appear before the Equitable Life Committee: Clive Maxwell (UK Treasury), David Strachan (FSA), and Christopher Daykin (Head of the Government Actuary's Department). Cf. European Parliament (2007). Equitable Life committee. Report on the crisis of the Equitable Life Assurance Society. Final Report (A6-0203/2007, 23.5.2007), pp. 20-21. 
Life Directive in the UK and other Member States. This included the so-called implementation reports as well as the reviews of the implementation reports. In addition, the Commission was asked to provide the committee with a complete list of documents in its possession related to the Equitable Life affair as well as a list of the infringement procedures that had been opened with Member States other than the UK with regard to the Third Life Directive. The Commission responded by sending the private study commissioned into the implementation of the Third Life Directive, the so-called 'Wilde Sapte study', as well as nine individual country reports. It also sent a list of relevant infringement proceedings and further information on the review of the study and relevant correspondence. ${ }^{413}$

\section{Meeting with members of staff from the UK Parliamentary Ombudsman}

On 29 March 2006, the rapporteur, Wallis, had a meeting with members of staff from the UK Parliamentary Ombudsman, who at that time were conducting an inquiry into alleged maladministration by UK authorities in the regulation of Equitable Life. The rapporteur discussed possible ways of organizing cooperation between the UK Ombudsman and the Equitable Life committee. The question was raised as to whether and, if so, what kind of information the Ombudsman would be willing to share. For instance, the Ombudsman had already carried out a detailed analysis of the UK regulatory system for life assurance, something which the committee was also required to do under its mandate. However, the Ombudsman's staff underlined the fact that the Ombudsman was not empowered to disclose any information obtained in the course of its investigation other than through its final report. ${ }^{414}$ Unfortunately for the committee, the Ombudsman's final report had not been published when the committee finished its inquiry. The committee was thus not able to make use of the information gathered by the UK Parliamentary Ombudsman.

\section{External expert studies}

The committee commissioned three external expert studies from its budget for the first three key points of the mandate.415 The studies were conducted by experts associated to the Centre for Commercial Law Studies, Queen Mary University of London, and the British Institute of International and Comparative Law. The experts presented their findings to the committee on 5 October 2006 during one of the two workshops organized in the context of the inquiry. ${ }^{416}$

\section{Fact-finding visits}

As part of the evidence-gathering process, the committee made fact-finding visits to Dublin and London in October 2006. In Dublin, committee members

\footnotetext{
413 European Parliament (2007). Equitable Life committee. Report on the crisis of the Equitable Life Assurance Society. Final Report (A6-0203/2007, 23.5.2007), pp. 27-28.

${ }^{414}$ Ibid. p. 28.

415 European Parliament (2007). Equitable Life committee. Report on the crisis of the Equitable Life Assurance Society. Final Report (A6-0203/2007, 23.5.2007), p. 29.

${ }^{416}$ Ibid. p. 30.
} 
met Irish Equitable Life policyholders and financial services regulators as well as the Irish Financial Services Ombudsman and the former Insurance Ombudsman of Ireland. In London, they met inter alia British policyholders, the Economic Secretary to the Treasury, the Financial Service Authority (FSA) chairman, the Financial Ombudsman Service (FOS), and the Parliamentary Ombudsman. ${ }^{417}$

\subsubsection{The committee's final report}

On 23 May 2007, the Equitable Life committee adopted its final report. The report consists of seven parts. Parts 2, 3, 4 and 5 deal with the four key points of the mandate. In part 7 , the committee presents its recommendations for each key point.

The first key point of the committee's mandate was to investigate alleged contraventions or maladministration in the transposition and application of the Third Life Directive (Directive 92/96/EEC) by the UK. The committee revealed shortcomings in the way the UK transposed the Third Life Directive into national law, since the transposition was not carried out in a way which allowed the effective fulfilment of its underlying objectives. With regard to the application of the Directive, the committee considered that the UK applied it deficiently and that UK regulators and authorities did not adequately respect its ultimate purpose. ${ }^{418}$ The committee concluded that the implementation process of the Third Life Directive was 'flawed' due to the combination of a formalistic transposition with a defective application. ${ }^{419}$

The second key point of the committee's mandate was to assess the supervision by UK regulators of Equitable Life's business practices and financial standing, as required by the Third Life Directive. ${ }^{420}$ The committee revealed that the UK consistently applied a 'light touch' regulatory policy to the life insurance business. This contributed to a weak regulatory environment, which allowed the problems of Equitable Life to grow unchecked. Also problematic was the fact that the British company Equitable Life was supervised by UK regulators, even though its activities were spread over several EU Member States. German and Irish regulators appeared to be mere bystanders with little control over the insurance business being carried out in their respective territories. ${ }^{421}$ Overall, the committee concluded that the development of the internal market in financial services was given more priority than ensuring sufficient consumer safeguards were in place. ${ }^{4.22}$ The Equitable Life committee therefore called for stronger supervisory and regulatory standards throughout the EU for increased supervisory cooperation. ${ }^{423}$

The third key point of the committee's mandate was to assess the adequacy of remedies available to policyholders for obtaining redress for their losses as a

\footnotetext{
${ }_{417}$ Ibid. p. 29.

418 Ibid. p. 117.

419 Ibid. p. 117.

420 Ibid. p. 125.

${ }^{421}$ Ibid. p. 204.

422 Ibid. p. 204.

${ }^{423}$ Ibid. pp. 360-361.
} 
consequence of the Equitable Life crisis. ${ }^{424}$ The committee noted that a large number of people both in the UK and in other EU Member States had suffered as a result of the crisis at Equitable Life. Oral and written evidence had shown that many policyholders had great difficulty in knowing what route to take or who to apply to in trying to obtain information, to make a complaint and to obtain redress for their financial losses. ${ }^{425}$ The committee concluded that accessible legal redress through courts as well as effective alternative means of redress were absent, both for UK policyholders and non-UK policyholders and both on the national and the EU level. The committee strongly recommended the UK government implement an appropriate scheme to compensate Equitable Life policyholders in the UK and elsewhere. With a view to filling the gaps at the EU level, the Equitable Life committee put forward several proposals and it requested the Commission take action in this regard. ${ }^{426}$ Finally, the committee strongly recommended that the Parliament, the Council and the Commission, when legislating in the financial services area, bear in mind the need to draft legislation in a way which grants the individual consumer clearly defined rights which can be relied upon before national courts. ${ }^{427}$

The fourth key point of the committee's mandate was to analyze whether there had been systematic weaknesses in the Commission's monitoring of implementation in general and with regard to the Equitable Life case in particular. ${ }^{428}$ Concerning the Commission's role in the Equitable Life case, the committee concluded that the Commission had not monitored the application of the Third Life Directive effectively. Instead of taking a proactive stance, the Commission had simply waited for complaints to arrive. ${ }^{429}$ The Commission checked the formal legal transposition of the Directive into UK law, but it refrained from monitoring the practical application of the Third Life Directive by the national authorities. ${ }^{430}$

The Equitable Life committee formulated several recommendations to improve the quality of legislation and its evaluation over time. It called on the Commission to demonstrate its increased focus on implementation and enforcement of Community legislation and to ensure that any directive adopted be implemented consistently across the European Union, in line with its 'Strategic Review of Better Regulation in the EU'431. In order to ensure this, the committee recommended the application of the 'Lamfalussy process' ${ }^{432}$, as

\footnotetext{
${ }^{424}$ Ibid. p. 209.

${ }_{425}$ Ibid. p. 210.

${ }^{426}$ Ibid. pp. 362-363.

${ }_{427}$ Ibid. p. 364.

${ }_{428}$ Ibid. p. 319.

${ }_{429}$ Ibid. p. 338.

430 Ibid. p. 332.

${ }_{431}$ European Commission (2006). A strategic review of Better Regulation in the European Union (COM/2006/689, 14.11.2006).

432 The 'Lamfalussy process' is an approach to the development of financial services industry regulations adopted by the EU (named after the chair of the EU advisory committee that devised it), consisting of four levels: Level 1: The EP and Council adopt legislation in codecision, determining framework principles and guidelines on implementing powers. Level 2: Technical implementing measures taking the form of further directives and/or
} 
well as increased involvement of national parliaments in the implementation of directives. ${ }^{433}$

\subsubsection{The role of committees of inquiry}

The Equitable Life committee devoted the sixth part of its report to the role of committees of inquiry of the European Parliament in general. The committee noted that committees of inquiry are an important part of the Parliament's supervisory power and that, although the Parliament's political stature had grown, the constitutional framework had not changed since the Interinstitutional Agreement entered into force in 1995.434 It observed that, even if the standing committees accomplish their supervisory responsibilities very satisfactorily, the Parliament's investigative work should not be conducted solely by such committees, since temporary committees of inquiry are committees focused on one specific task, with Members from different committees bringing different experiences and knowledge. ${ }^{435}$

The committee pointed out that it had been limited in its investigation by a number of formal restrictions, except with regard to the Commission. It expressed "irritation and regret at the discourteous conduct of several witnesses who did not cooperate with the inquiry" and voiced its conviction that committees of inquiry should be strengthened. ${ }^{436}$ It therefore requested the Policy Department 'Citizens' Rights and Constitutional Affairs' carry out a comparative study on parliamentary committees of inquiry in selected EU Members States ${ }^{437}$ and Switzerland. ${ }^{438}$ The study's aim was to develop criteria for possible modifications of the powers of the committees of inquiry of the European Parliament. ${ }^{439}$ The findings of the study are summarized hereafter.

\section{Comparative study on committees of inquiry}

The comparative study reveals that the majority of Member States (except for the UK House of Commons) have a constitutional system that provides for parliamentary committees of inquiry. Some of the British select committees

regulations, adopted under powers delegated at level one. Level 3: Networking between regulators with a view to producing joint interpretative recommendations, consistent guidelines and common standards, peer review, and comparisons between regulatory practices to ensure consistent implementation and application. Level 4: Monitoring by the European Commission of Member States' compliance with EU legislation and enforcement action where necessary.

433 European Parliament (2007). Equitable Life committee. Report on the crisis of the Equitable Life Assurance Society. Final Report (A6-0203/2007, 23.5.2007), p. 336.

${ }^{434}$ Ibid. p. 346.

435 Ibid. p. 346.

${ }_{436}$ Ibid. p. 357.

${ }_{437}$ The EU Member States are: Austria, Belgium, Finland, France, Germany, Greece, Ireland, Italy, Netherlands, Spain, Sweden and the UK.

${ }_{438}$ European Parliament (2007). AFCO committee. Parliamentary committees of inquiry: a survey (31.1.2007). The survey is divided in two parts: the main part concentrates on the issues raised by the Equitable Life Committee. The annex presents supplementary data collected in the 2003 survey conducted by the European Centre for Parliamentary Research \& Documentation (ECPRD).

439 European Parliament (2007). AFCO committee. Parliamentary committees of inquiry: a survey (31.1.2007), p. 4. 
(both in the House of Commons and the House of Lords), however, have objectives and procedures similar to inquiry committees in other countries. Nonetheless, they are different since they usually have an open-ended mandate, much like standing committees in other parliaments. The legal framework for the creation of inquiry committees in most countries includes provisions either in the constitution, ordinary law, or the parliamentary rules of procedure. In some countries, the legal basis is found on all three levels, whereas in other countries the relevant provisions can be found in just one or two of the aforementioned categories. ${ }^{440}$

\section{Establishment and composition}

In most countries, a committee of inquiry is proposed and established by majority vote. In Germany, however, the right of inquiry is designed to guarantee the rights of a parliamentary minority. In Greece, on the other hand, a decision for the establishment of an inquiry committee is taken by increased majority vote. ${ }^{441}$ The composition of the committees reflects in most states the composition of the parliament. However, in Austria and in the UK House of Lords, the composition is specific and does not necessarily reflect the composition of the parliament. ${ }^{442}$

\section{Time limit}

The various systems differ strongly as to whether an inquiry has a fixed duration. In seven countries, there is no such time limit (Austria, Finland, Ireland, the Netherlands, Sweden, Switzerland and the UK (House of Lords)). In Spain it depends on the specific case and in the other countries there is such a time limit. ${ }^{443}$ French committees of inquiry have to perform their duties within a rather tight timeframe, namely within six months. If an inquiry committee has not finished a final report upon the expiry of six months, its chair shall deliver the papers in his possession to the President of the Assemblée Nationale. Those papers shall neither be published nor shall they be debated. ${ }^{444}$

\section{Purpose of inquiry committees}

The main purpose of inquiry committees in most systems is to supervise the actions of the government or the administration. In some states (Belgium, Spain (both Senate and Congress), and Sweden) the committees have the additional duty to ensure respect of the Constitution or other legal provisions. ${ }^{445}$

\section{Public nature of the inquiry}

The inquiry proceedings in five countries, as a rule, are public (Belgium, France, Germany, Ireland and the UK (House of Lords)), whereas in five other systems (Austria, Italy, the Netherlands, Spain and Sweden) the public

\footnotetext{
${ }_{440}$ Ibid. p. 4.

${ }_{441}$ Ibid. p. 14.

${ }^{442}$ Ibid. pp. 15-16.

${ }^{443}$ Ibid. pp. 18-19.

${ }_{444}$ Ibid. p. 24.

${ }_{445}$ Ibid. p. 4.
} 
character of the proceedings depends on a case-by-case decision. Inquiry proceedings are generally held in camera in Finland, and they are always held in camera in Greece and Switzerland. ${ }^{446}$

\section{Gathering of oral evidence}

The comparative study reveals that in all Member States with a legal basis for inquiry committees (except Finland) there is a possibility to summon witnesses such as heads of public bodies or other citizens to give evidence. ${ }^{447}$ Sanctions differ from country to country in cases of non-compliance with an invitation to appear before an inquiry committee. In Greece, for example, the chair of a committee may enforce the compulsory attendance of the witness, whereas in Ireland a refusal to appear before a committee may lead to the presentation of a case to the High Court for an order to appear. Refusal to comply may also constitute a criminal offence. A refusal to give evidence without justification may lead to an administrative fine in Austria. In the Netherlands, witnesses who refuse to appear before the committee or who deliberately do not attend may even be imprisoned. ${ }^{448}$

\section{Access to documents}

The comparative study indicates that in most Member States, committees of inquiry can require the transmission of information and documentation deemed necessary for the conduct of their investigations from a certain number of administrative or political bodies such as the government, judicial authorities, or administrative authorities. In a few countries, committees can also oblige private bodies to collect information for them. ${ }^{449}$ In most countries, inquiry committees have mechanisms to deal with a refusal of such bodies to cooperate, ranging from administrative fines (Austria) to imprisonment (the Netherlands). ${ }^{450}$

\section{Relations with courts}

In addition to the abovementioned right of access to documents, inquiry committees can in several countries (Austria, Belgium, Finland, Italy, Sweden and Switzerland) ask the courts for documents, and the courts normally comply with such requests. Conversely, in other countries (France, Ireland, Greece and the Netherlands) there is no direct interaction between inquiry committees and courts. ${ }^{451}$ In most countries, committees of inquiry can be established despite the fact that the matter of investigation is simultaneously under judicial review (sub judice). However, in five countries (France, Germany, Ireland, the UK and Switzerland) simultaneous investigation of the same matter is inadmissible. In most countries, courts can require inquiry documents from the parliament and

\footnotetext{
446 Ibid. pp. $21-22$.

447 Ibid. pp. $20-21$.

448 Ibid. pp. 5 and 10-11.

449 Ibid. pp. 5 and 8-9.

450 Ibid. pp. 5 and 10-11.

${ }^{451} \mathrm{Ibid}$. pp. 5 and 11-12.
} 
inquiry committees can forward - on their own or via the parliament - findings of criminal activities to the police or the public prosecutor. ${ }^{452}$

\section{Assistance in the performance of duties}

Committees of inquiry generally rely on internal and external assistance. In Austria, Italy and Switzerland, for instance, committees are granted additional help from external advisers to be hired by the inquiry committee as well as from judicial authorities, the criminal police and other administrative authorities. All national inquiry committees - except for the Finnish - can, in addition to the internal parliamentary assistance, rely on external assistance. ${ }^{453}$

\section{Final report and follow-up}

At the end of the inquiry, the committees generally draw up their conclusions in a final report. The submission of a final report is mandatory in Austria, Germany, Ireland, the Netherlands, Sweden, Switzerland and the UK (House of Lords). In general, the final reports are published. However, in some countries (Austria, Greece, Sweden, Switzerland and the UK (House of Lords)) publication is subject to parliamentary approval. ${ }^{454}$

\section{Conclusions of the comparative study}

On the basis of the comparative findings discussed, the authors of the report conclude that the rules concerning temporary committees of inquiry of the European Parliament "still leave some leeway for a further evolution of the responsibilities of these bodies". ${ }^{455}$ More in particular, they conclude that: "a tightening of the rules governing sanctions for persons or institutions refusing to cooperate would appear useful. Closer cooperation with national authorities could be one way of achieving this. However, the wide discrepancies between the sanctions provided for in different national systems could possibly create problems of discrimination in the European Parliament's treatment of EU citizens via national institutions". ${ }^{456}$

\section{The Equitable Life committee's recommendations on the right of inquiry}

The Equitable Life committee made use of the findings of the comparative study and it formulated recommendations concerning the right of inquiry of the European Parliament. The committee recommended that the Parliament initiate work with a view to proposing a modification of the Interinstitutional Agreement to the Commission and the Council. It observed that the Parliament's powers of inquiry should be improved and aligned with those of the majority of the Member States' parliaments. In particular, the committee pointed out the need to give them the power to summon witnesses and papers in close cooperation with Member States' authorities, which should be bound to

\footnotetext{
452 Ibid. pp. 22-23.

453 Ibid. pp. 5 and 18-19.

454 Ibid. pp. 23-25.

455 Ibid. p. 5.

${ }_{456}$ Ibid. p. 5.
} 
comply with such requests and to cooperate closely throughout the inquiry. ${ }^{457}$ The committee furthermore recommended that committees of inquiry be given an autonomous right to require the attendance of witnesses who are domiciled or resident within the European Union, and that they are required willingly, fully and truthfully to answer questions from members of the committee. ${ }^{458}$

\subsubsection{Plenary debate of 19 June 2007}

The Equitable Life committee presented its report in plenary on 19 June 2007. The report was debated with the Commissioner for the Internal Market, Charlie McCreevy. ${ }^{459}$ The rapporteur, Wallis (ALDE), opened the debate. She stated: "I believe this report will assist the victims in a pincer movement with the UK Parliamentary Ombudsman, perhaps finally to deliver compensation. More importantly, I hope it will deliver a huge jolt to our institutions about our lawmaking processes and the European system of justice." Commissioner McCreevy assured the Parliament that the Commission would give most serious consideration to all recommendations addressed to it. He furthermore informed the Parliament about the 'Solvency II proposal' he was intending to present to the College of Commissioners one month later. McCreevy pointed out that Solvency II was to reform and update insurance supervision and regulation in the European Union. A key element of the project was the aim of linking the capital requirements for insurance undertakings much more closely to their precise risk profile. He elucidated that it "will not be a zero-failure regime but will [...] make a collapse, such as that of Equitable Life, much more unlikely in the future". On the wider issue of ensuring Community law is correctly applied and the way transposition is monitored, McCreevy promised that the Commission would come up with ideas to improve the application of Community law.

Mairead McGuinness (EPP-ED), the committee chair, stressed the value of the inquiry in bringing the Parliament's work closer to the citizens. She also stressed that the UK implementation of the Third Life Directive was flawed: "yes, it ticked the boxes, but its day-to-day application was deficient and inadequate”.

With a large majority, the Parliament endorsed the committee's report (602 votes to 13 , with 64 abstentions).

\section{Recommendation}

On the basis of the report, the Parliament adopted a recommendation calling on the Council, the Commission and the Member States to ensure that the conclusions and recommendations arising out of the inquiry were acted upon. ${ }^{460}$ In particular, the Commission was required to ensure that the

\footnotetext{
457 European Parliament (2007). Equitable Life committee. Report on the crisis of the Equitable Life Assurance Society. Final Report (A6-0203/2007, 23.5.2007), p. 369.

458 Ibid. p. 369.

459 The literal transcripts of the plenary debate of 18 February 1997 are available online under: http://www.europarl.europa.eu/comparl/tempcom/equi/default_en.htm (click on 'Plenary debate - 19 June').

${ }^{460}$ European Parliament recommendation of 19 June 2007 on the report of the committee of inquiry into the crisis of the Equitable Life Assurance Society (B6-0199/2007).
} 
conclusions and recommendations on implementation matters were acted upon swiftly and to report back to the competent standing committees of the Parliament. The Parliament furthermore invited its president to instruct the relevant standing committees (Economic and Monetary Affairs, Internal Market and Consumer Protection, Legal Affairs, Constitutional Affairs and Petitions) to monitor the implementation of the committee's conclusions and recommendations, especially those pertaining to the Commission's responsibilities concerning transposition and redressing issues in the context of the internal market, and, if appropriate, to report thereon.

Finally, the plenary called on the Conference of Presidents and the Working Party on Parliamentary Reform set up in February 2007 "to enact the recommendations contained in the report with respect to closer cooperation with national parliaments and improved oversight by Parliament on implementation issues, as well as on the future reform of inquiry committees, in order to improve their functioning and effectiveness". ${ }^{461}$

\subsubsection{Follow-up to the inquiry}

In February 2009, Gerardo Galeote (Chairman of the Conference of Committee Chairs ${ }^{462}$ ) reported to the President of the European Parliament on the actions taken since the end of the Equitable Life inquiry. ${ }^{463}$ Galeote reported an increased focus of parliamentary committees on the transposition and implementation of Community law and he further touched upon the Second Interim Report of the Working Party on Parliamentary Reform, which includes proposals concerning the transposition and implementation of Community law and proposals regarding relations with national parliaments. ${ }^{464}$ In the report, the Working Party on Parliamentary Reform praised the Equitable Life committee for its "valuable suggestions" as to how Parliament could improve its scrutiny of application of EU law. ${ }^{465}$

In response to the Equitable Life committee's request for the Commission to investigate further the possibility of setting up a legal framework with uniform civil procedural requirements for European cross-border collective actions, the Commission presented a 'Green Paper on Consumer Collective Redress' in November 2008, proposing a number of options to address the unsatisfactory consumer redress situation. ${ }^{466}$ The committee on the Internal Market and

\footnotetext{
461 Ibid.

462 The 'Conference of Committee Chairs' consists of the chairmen of all the standing and temporary committees. Its main function is to coordinate the work of the EP committees and to enhance the cooperation between the committees. $C f$. Rule 24 Rules of Procedure of the European Parliament, and: Corbett/Jacobs/Shackleton (2011), p. 142.

${ }_{463}$ European Parliament (2009). Conference of Committee Chairs. Letter of 11 February 2009 from Gerardo Galeote forwarding his report on the action taken in the parliamentary committees concerned on the basis of the recommendations of the Committee of Inquiry into the Equitable Life Assurance Society (PE 421.757/CPG), pp. 3-4.

${ }_{464}$ European Parliament (2008). Working party on parliamentary reform. Second Interim Report on Legislative Activities and Interinstitutional Relations (Part B, PE 406.309/CPG/GT/B, 15.5.2008).

${ }_{465} \mathrm{Ibid}$. pp. 50-51.

466 European Commission (2008). Green Paper on Consumer Collective Redress (COM/2008/794, 27.11.2008).
} 
Consumer Protection further held an exchange of views with Commissioner Kuneva (Consumer Affairs) on the Green Paper. ${ }^{467}$ Reporting on the recommendations for the role of European Parliament's committees of inquiry, the committee on Constitutional Affairs stated that a revision of the interinstitutional agreement would require "complicated negotiations" with the Commission and the Council. The committee on Constitutional Affairs referred to the Treaty of Lisbon, which includes a special legislative procedure for such cases which, according to the committee on Constitutional Affairs, would "reinforce" the Parliament's position in the negotiations. ${ }^{468}$ It therefore suggested that this matter be reconsidered at the beginning of the next legislative term (2009-2014).469 Shortly after the 2009 elections, David Martin $(\mathrm{S} \& \mathrm{D})$ was appointed rapporteur to create a proposal for the revision of the detailed provisions governing the exercise of the right of inquiry. ${ }^{470}$

The executive actor which was blamed most for the Equitable Life fiasco proved the least responsive to the outcome of the inquiry. The UK government did not respond officially to the final report of the Equitable Life inquiry and it even remained silent on the issue after the President of the European Parliament asked UK prime minister Gordon Brown on 5 December 2007 to "ensure that the authority of the Parliament and of its right of inquiry enshrined in the EC Treaty do not risk being prejudiced by the lasting lack of formal response by the British Government". ${ }^{471}$

\subsubsection{Assessment of the parliamentary inquiries held since 1993}

This section assesses the three committees of inquiry held since 1993 as regards the gathering of evidence and their working methods. It will be examined whether, and if so, to what extent, these committees were hampered by their relatively weak legal position.

\subsubsection{Gathering of evidence}

This section discusses the gathering of oral and written evidence, and other means of gathering evidence employed by the committees of inquiry.

\section{Oral evidence}

All committees made full use of the ability to invite persons to testify before them. The committees of inquiry into Transit, BSE, and Equitable Life invited 62, 34 and 58 persons respectively. Witnesses of all three categories under Article 3 Interinstitutional Agreement were invited: (1) members of an

\footnotetext{
${ }_{467}$ European Parliament (2009). Conference of Committee Chairs. Letter of 11 February 2009 from Gerardo Galeote forwarding his report on the action taken in the parliamentary committees concerned on the basis of the recommendations of the Committee of Inquiry into the Equitable Life Assurance Society (PE 42 1.757/CPG), pp. 3-4.

${ }^{468}$ Cf. Section 2.3.2.

469 European Parliament (2009). Conference of Committee Chairs. Letter of 11 February 2009 from Gerardo Galeote forwarding his report on the action taken in the parliamentary committees concerned on the basis of the recommendations of the Committee of Inquiry into the Equitable Life Assurance Society (PE 421.757/CPG), p. 6.

${ }^{470}$ Section 2.6.2 discusses the work of rapporteur David Martin (S\&D).

471 Jones (2008).
} 
institution or a body of the European Union or the government of a Member State, (2) officials and servants, and (3) other persons. ${ }^{472}$

All committees of inquiry invited Commissioners to give evidence before them. The close institutional ties between the Parliament and Commission accounted for the fact that none of the Commissioners invited refused to comply with a committee's request to testify. The fact that the ties are less close between the Parliament on the one hand, and the Council and the governments of the Member States on the other, was particularly problematic in the course of the inquiries into the BSE and Equitable Life crises. The Transit committee was aware of its formally limited position and it therefore did not even try to invite members of national governments. ${ }^{473}$ The committees investigating the BSE and Equitable Life crises, however, did invite members of national governments. Nevertheless, the UK agriculture minister, Douglas Hogg, refused to appear before the BSE committee and the Irish Minister for Enterprise, Trade and Employment, Michael Martin, declined to accept an invitation from the Equitable Life committee.

The Commission also proved to be cooperative with the inquiry committees with respect to the second category of witnesses: the officials and servants. Requests to designate Commission officials to the inquiry committee hearings were complied with. Furthermore, the Transit and the BSE committees did not face problems as regards the attendance of national civil servants at its hearings. However, the Equitable Life committee was less successful in this respect. Several UK civil servants requested to appear as a witness did not appear before the Equitable Life committee. Perhaps this was a consequence of the Equitable Life committee inviting specific civil servants to appear, rather than requesting national authorities to designate and authorize a servant to appear (as prescribed in Article 3 (3) IIA).

The committees also made full use of the ability to invite persons of the residual category: 'other persons'. The invitation of these witnesses proved to be an important means of gathering evidence. In the case of the Transit inquiry, individuals and representatives of organizations provided the committee with their practical experiences in the field. Since the inquiry into BSE was very technical in nature, technical and scientific knowledge was needed in the course of that inquiry. Therefore, the BSE committee invited external experts in the field of BSE, such as veterinary medics, microbiologists, zoologists, agricultural engineers and pharmacists, in order to gain a better understanding of the technical aspects. The Equitable Life committee invited persons of the residual category to offer disadvantaged Equitable Life policyholders a platform to voice their displeasure with the crisis of the Equitable Life Assurance Society and its aftermath. The evidence given by these 'other persons' was of great importance to the three committees of inquiry. External persons with practical and/or theoretical knowledge were used to inform committees of inquiry about the specific issues under investigation. Sufficient knowledge of a specific issue on the part of inquiry

${ }^{472} \mathrm{Cf}$. Section 2.4.4.1 on the right to call witnesses.

${ }_{473}$ European Parliament (1997). Transit committee. Chairman's report on the working methods of the Committee of Inquiry into the Community Transit System (PE 220.696/rev., 21.2.1997), p. 7. 
committees is necessary in order for them to assess thoroughly the conduct of executive actors in the field and, subsequently, to draw solid conclusions. The evidence given by this category of witness was all the more important for the committees of inquiry in view of the limited internal resources of the inquiry committees in terms of staff and funding. External knowledge thus served as some sort of compensation for insufficient internal capacity and knowledge.

\section{Written evidence}

The three committees of inquiry gathered written evidence by sending requests to relevant authorities, organizations and persons. Although written evidence sometimes reached the committees without being requested, the three inquiries have shown that authorities tend to wait for an explicit request before sending documents to a committee of inquiry. Difficulties stem from the committees of inquiry generally not knowing which relevant documents exist, and if they do not ask for specific documents, the authorities generally are not keen to forward these documents to them. It was for this reason that the BSE committee made grateful use of information that it received 'off the record' from persons who preferred to remain anonymous. These persons informed the BSE committee of the existence of relevant Commission documents. The BSE committee was subsequently able to gather these documents after sending specific official requests to the Commission to forward these documents. ${ }^{474}$ Sometimes written evidence was already available on the internet or elsewhere, which for example was the case with the various other reports that had been written on the Equitable Life case.

The three committees of inquiry all found their own ways of gathering written evidence. The Transit committee collected written evidence inter alia by circulating a lengthy questionnaire to all Member States requesting detailed national statistics and policy orientations. Similarly, the Equitable Life committee circulated a questionnaire with detailed questions to non-UK Equitable Life policyholders. After its oral hearings, the BSE committee put numerous additional questions to witnesses in writing, which the committee considered a most valuable means of gathering further details and clarification in respect of witnesses' oral contributions. ${ }^{475}$

\section{Other means of gathering evidence}

The three committees of inquiry also found alternative means of gathering information throughout their respective inquiries. One of these was on-the-spot fact-finding visits. The Transit, BSE and Equitable Life committees conducted five, one, and two such visits respectively. Furthermore, with a view to better understanding the technical details of the matter at hand, the Equitable Life committee commissioned an external study on each part of its mandate. The academic experts who carried out these studies presented their findings to the Equitable Life committee during workshops organized in the context of the inquiry.

${ }^{474}$ Interview with Reimer Böge, 21 June 2011.

475 European Parliament (1997). BSE committee. Report on alleged contraventions or maladministration in the implementation of Community law in relation to BSE (Part B, A40020/97/B, 7.2.1997), p. 3. 


\subsubsection{Three inquiries, one working method?}

The terms of the Treaty provision and the Interinstitutional Agreement were not amended between the three inquiries. Thus the committees of inquiry conducted their investigations within an identical legal framework. The question arises as to how they conducted their inquiries and whether there was a common working method.

In their quest for relevant information on the respective matters under investigation, the three committees heard witnesses, conducted fact-finding visits, collected written evidence and, in the case of Equitable Life, commissioned external expert studies. The meticulous way in which the three committees endeavoured to gain a deep understanding of the matters being investigated may be seen as a common feature. This meticulous attitude indicated that the committees wanted to substantiate their conclusions on the basis of scientific findings and practical experience, which certainly had a positive influence on the credibility and legitimacy of their respective final reports.

However, there was a difference in the way the committees dealt with their limited legal position. The Transit committee took an approach of strict adherence to the legal framework. It accepted that inquiry committees were limited in power and that witnesses were little more than 'voluntary cooperators'. As a consequence, in order to avoid the embarrassment of a refusal, the Transit committee did not invite national ministers to appear before it. ${ }^{476}$ The other committees, by contrast, tested the limits of the legal framework and proved keen to find out how broadly the relevant legal provisions could be interpreted. Despite the lack of a right of summons vis-à-vis national ministers, both committees invited national ministers to appear before them. Whereas the Equitable Life committee expressed "irritation and regret at the discourteous conduct of several witnesses who did not cooperate with the Inquiry" ${ }^{477}$, the BSE committee argued that the refusal of a British national minister reflected a failure on the part of the British government to comply with the Interinstitutional Agreement. ${ }^{478}$

The committees' recommendations for the future shape of the right of inquiry of the European Parliament were in keeping with their respective approaches. The Transit committee mainly gave recommendations for informal mechanisms to be used by inquiry committees within the existing legal framework ${ }^{479}$, whereas the other committees mainly focused on changing the legal framework. Moreover, they proposed equipping inquiry committees with stronger formal powers, such as a right to autonomous inspection of files, a right of summons, a right to swear in witnesses, and a right to penalize witnesses and authorities in the event of their refusal to cooperate in the course of the inquiry. ${ }^{480}$

\footnotetext{
476 Shackleton (1998), p. 128.

477 European Parliament (2007). Equitable Life committee. Report on the crisis of the Equitable Life Assurance Society. Final Report (A6-0203/2007, 23.5.2007), p. 357.

${ }_{478}$ This argument has been countered in Section 2.5.2.3.

${ }^{479}$ Cf. Section 2.5.1.4.

${ }^{480} \mathrm{Cf}$. Sections 2.5.2.5 and 2.5.3.4.
} 
The different approaches of the BSE and Equitable Life committees on the one hand and the Transit committee on the other can be explained firstly by the differing volatility of the respective issues. The BSE and Equitable Life issues were politically salient, and thus required a more inquisitorial approach to define political responsibilities, whereas the Transit issue was less politically salient and the committee thus focussed on discovering weaknesses in the Transit System rather than defining political responsibilities. A second explanation for the different approaches could be the differing backgrounds of the respective chairpersons. The BSE and the Equitable Life committees were chaired by the German Reimer Böge and the Irish Mairead McGuinness respectively, who might have projected the strong investigative powers of 'their' national parliamentary committees of inquiry on those of the European Parliament. John Tomlinson, the British chairman of the Transit committee on the other hand, might have had the working methods of UK select committees in mind, which are less focussed on the use of strong formal powers.

It may thus be concluded that all of the committees made full use of the available opportunities to be informed about the respective matters under inquiry and to draw conclusions on the basis of that information. There was, however, no common approach with regard to the limited formal position of the committees. Whereas the Transit committee accepted its limited position under the existing legal arrangements, the committees into BSE and Equitable Life tried to stretch the rules of these arrangements by testing their limits.

\subsubsection{Legal limitations in practice}

The above section describes the inquiry proceedings of the three committees of inquiry. This section investigates whether, and if so, to what extent committees of inquiry were hampered by their relatively weak legal position.

\section{The right to call witnesses}

The extent to which the three inquiry committees succeeded in ensuring the appearance of witnesses before them depended very much on the executive actor invited.

The inquiry committees did not face difficulties with regard to the Commission, as the close institutional ties between the Parliament and the Commission ensured the attendance of Commissioners and people working for the European Commission at inquiry hearings.

Assuming that national ministers are to be categorized in the group 'members of national governments', rather than in the group 'members of the Council', it may be concluded that the inquiry committees furthermore experienced no problems with regard to the Council. The Irish Minister for Agriculture and President-in-Office of the Council of Agriculture Ministers, Sean Yates, accepted an invitation from the BSE committee to appear before it.

The three committees of inquiry were, however, on several occasions effectively hampered by their limited position when they tried to obtain the attendance of other national ministers, national civil servants and 'other persons' (as referred to in Article 3 (8) IIA). This became particularly clear during the BSE inquiry, when the UK Minister of Agriculture, Douglas Hogg, refused to give evidence before the BSE committee. However, this was not the 
only such incident. The lack of a right of summons severely hampered the work of the Equitable Life committee. Twenty witnesses - including several UK civil servants - refused to comply with a request by the committee to appear before it.

The fact that none of the persons invited to appear before the Transit committee refused does not automatically mean that this committee was not hampered by its limited legal position. The contrary rather seems to be true, since the Transit committee anticipated its limited position. In order to avoid the embarrassment of a refusal, it did not even try to invite members of national governments to appear before it. ${ }^{481}$ The chairman of the Transit committee pointed out explicitly that the absence of a right of summons had an important limiting effect on what the Transit committee could do. ${ }^{482}$ Such considerations - 'don't invite them because they won't come anyway' - may have influenced the proceedings of other inquiry committees as well.

All committees recognized that the legal position of committees of inquiry was limited with regard to the right to call witnesses. Whereas the Transit committee put up with this and made the best of it, the Equitable Life committee and the chairman of the BSE committee recommended that the Interinstitutional Agreement be amended and that committees of inquiry should be given a right of summons. ${ }^{483}$

\section{Legal position of witnesses}

The chairman of the Transit committee, John Tomlinson, pointed out that the limited legal position of committees of inquiry was particularly evident in relation to the rights and obligations of witnesses. He stressed that this had an important limiting effect on what the Transit committee could do. ${ }^{484}$ Besides the absence of a general right of summons, Tomlinson criticized the unilateral right of witnesses to provide testimony in camera, the inability to put witnesses under oath, and the absence of a means of penalizing false testimonies. ${ }^{485}$ This view was shared by his colleague, chairman of the BSE committee, Reimer Böge, who stated that the absence of such rights "makes it very difficult for a committee of inquiry to discover possible irregularities by hearing evidence from those concerned". ${ }^{486}$ The fact that officials gave evidence not as individuals, but on behalf of their institutions, presented a further obstacle to the work of the BSE committee. According to the BSE committee, the

\footnotetext{
${ }^{481}$ Cf. Shackleton (1998), p. 128.

482 European Parliament (1997). Transit committee. Chairman's report on the working methods of the Committee of Inquiry into the Community Transit System (PE 220.696/rev., 21.2.1997), p. 7.

${ }_{483}$ European Parliament (2007). Equitable Life committee. Report on the crisis of the Equitable Life Assurance Society. Final Report (A6-0203/2007, 23.5.2007), p. 369; and: European Parliament (1997). BSE committee. Chairman's observations on institutional aspects of the work of the committee of inquiry (PE 220.853, 7.1.1997), p. 3.

${ }^{484}$ European Parliament (1997). Transit committee. Chairman's report on the working methods of the Committee of Inquiry into the Community Transit System (PE 220.696/rev., 21.2.1997), p. 7.

${ }_{485}$ Ibid. pp. 8-9.

486 European Parliament (1997). BSE committee. Chairman's observations on institutional aspects of the work of the committee of inquiry (PE 220.853, 7.1.1997), p. 2.
} 
Commission had employed this provision to conceal the truth from the committee on various sensitive issues. ${ }^{487}$ This shows that the fact that persons appear before a committee of inquiry does not necessarily imply that these persons give rewarding answers, or give answers at all. In this sense, it would seem useful to follow up on the Transit committee chairman's recommendation of giving the fullest publicity to the testimonies to ensure that those outside as well as those on the committees of inquiry can judge the nature and quality of the evidence given. In that sense, publicity can serve as a tool to put pressure on witnesses to refrain from concealing relevant information before a committee of inquiry. The Equitable Life committee, which also recognized problems with regards to the legal position of witnesses, recommended that witnesses be required to answer questions from members of committees of inquiry willingly, fully and truthfully. ${ }^{488}$ Whereas the chairman of the BSE committee formulated a similar recommendation ("A European Parliament committee of inquiry must have the right to swear in witnesses. It must be possible to prosecute witnesses if they give false testimony" ${ }^{489}$ ), the Transit committee, again, put up with its limited position. Its chairman did not recommend introducing a right of summons, but recommended giving careful consideration to how to cross-examine witnesses. He also recommended withdrawing the unilateral right of witnesses to give evidence in camera. ${ }^{490}$

\section{Access to documents}

Following Article 3 (4) Interinstitutional Agreement, both EU and national authorities are under a duty to provide a committee of inquiry, at the latter's request, with all documents necessary for the inquiry. Committees of inquiry, however, do not have an autonomous right to seize files in order to prevent the authorities under investigation from concealing incriminating information. In practice this means that the authorities under investigation are in the strong position of being able to decide for themselves when and which documents they forward to committees of inquiry. The limited position of committees of inquiry with respect to access to documents was felt by the BSE committee when the UK government proved unwilling to release documents to it. As a consequence of this unwillingness on the part of the UK government, the BSE committee felt "severely hampered" in its efforts to clarify responsibilities for the BSE crisis. ${ }^{491}$ The chairman of the BSE committee observed that there was "much less likelihood of discovering omissions on the part of the authorities

487 European Parliament (1997). BSE committee. Report on alleged contraventions or maladministration in the implementation of Community law in relation to BSE (Part AI and AII, A4-0020/97/A, 7.2.1997), p. 36.

488 European Parliament (2007). Equitable Life committee. Report on the crisis of the Equitable Life Assurance Society. Final Report (A6-0203/2007, 23.5.2007), p. 369.

489 European Parliament (1997). BSE committee. Chairman's observations on institutional aspects of the work of the committee of inquiry (PE 220.853, 7.1.1997), p. 3.

490 European Parliament (1997). Transit committee. Chairman's report on the working methods of the Committee of Inquiry into the Community Transit System (PE 220.696/rev., 21.2.1997).

491 European Parliament (1997). BSE committee. Report on alleged contraventions or maladministration in the implementation of Community law in relation to BSE (Part AI and AII, A4-0020/97/A, 7.2.1997), p. 14. 
under investigation", since any document forwarded to the committee by the Council, Commission or national authorities had already been scrutinized by those whose actions the committee was supposed to be scrutinizing. ${ }^{492}$ José Happart (PES), who was a member of the BSE committee, deplored the fact that most information and revealing documents from the Commission and the Council reached the inquiry committee by means of leaks or from information provided by journalists via the media. ${ }^{493}$ The Equitable Life committee also acknowledged the limited right of access to documents. ${ }^{494}$

However, the BSE and Equitable Life committees came up with different proposals for strengthening the right of access to Member States' documents. The chairman of the BSE committee recommended that the committees be given, like an investigating magistrate, a right to autonomous inspection of files, even with regard to national administrations. ${ }^{495}$ This implies a right of direct access to documents without interference from the national authorities. The Equitable Life committee also recommended that committees be given the power to summon papers. However, contrary to the BSE committee chairman's proposal, it recommended that committees of inquiry do this in close cooperation with Member States' authorities, which should be bound to comply with such a request and to cooperate closely throughout the inquiry. ${ }^{496}$

\section{Other legal limitations in practice}

In addition to the powers regarding witnesses and documents discussed above, the three inquiry committees felt effectively hampered by other legal and practical limitations.

The BSE committee found that the deadline for the submission of the report was, willingly or unwillingly, used against the BSE committee by the Commission and the UK government. The Commission delivered written replies extremely slowly, and the BSE committee accused the UK government of using blocking tactics. As a consequence, the need to complete its work within the deadlines laid down meant that a number of questions remained unanswered.497 The committee concluded: "The pressure of time and the wording of the 1995 Interinstitutional Agreement made it impossible to attribute individual responsibility for maladministration". ${ }^{498}$ The Transit committee had a similar experience. It observed that, in view of its limited life

\footnotetext{
492 European Parliament (1997). BSE committee. Chairman's observations on institutional aspects of the work of the committee of inquiry (PE 220.853, 7.1.1997), p. 2.

493 European Parliament (1997). BSE committee. Report on alleged contraventions or maladministration in the implementation of Community law in relation to BSE (Part AIII, A4-0020/97/AIII, 7.2.1997), p. 5.

494 European Parliament (2007). Equitable Life committee. Report on the crisis of the Equitable Life Assurance Society. Final Report (A6-0203/2007, 23.5.2007), p. 346.

${ }_{495}$ European Parliament (1997). BSE committee. Chairman's observations on institutional aspects of the work of the committee of inquiry (PE 220.853, 7.1.1997), p. 2.

496 European Parliament (2007). Equitable Life committee. Report on the crisis of the Equitable Life Assurance Society. Final Report (A6-0203/2007, 23.5.2007), p. 369.

497 European Parliament (1997). BSE committee. Report on alleged contraventions or maladministration in the implementation of Community law in relation to BSE (Part AI and AII, A4-0020/97/A, 7.2.1997), p. 5.

${ }^{498}$ Ibid. p. 5.
} 
span, its work was “jeopardized” by Member States which did not react within a reasonable period to committee requests. ${ }^{499}$

The Transit committee's chairman further remarked that the resources available to the committee were insufficient both in terms of staff and funding. He observed that had the committee been granted financial resources equivalent to those available to committees of inquiry in some Member States, it would "doubtless have achieved more". With regard to staff, he recommended that the Parliament examine the possibility of seconding an outside expert with specific knowledge for the duration of an inquiry. ${ }^{500}$

\section{Concluding remarks on legal limitations in practice}

All of the committees acknowledged that they were effectively hampered in their respective inquiries as a consequence of the limited provisions of the Interinstitutional Agreement. The study of the three inquiries shows that the legally limited position of committees of inquiry was largely unproblematic in relation to the Commission. The close ties between the Parliament and the Commission ensured a responsive attitude of the Commission in the course of parliamentary inquiries. The Commission almost self-evidently complied with requests to send persons or documents to committees of inquiry. However, due to the lack of an autonomous right to seize files from the Commission, it is difficult to verify whether the Commission indeed forwarded all relevant information to committees of inquiry. This is mutatis mutandis the case with regard to the right of access to documents from Member States and the Council.

More problematic was the relationship between the committees of inquiry and Member State authorities. For members of national governments and, to a lesser extent, national civil servants, cooperation with inquiry committees seemed far from self-evident. The last inquiry reached a precarious stage with a substantial number of 'national witnesses' refusing to comply with requests to give evidence before the Equitable Life committee.

The situation with regard to the Council is somewhat diffuse, and, as a consequence, difficult to assess. On the one hand, the national ministers (who as a matter of course are members of the Council at the same time) seem to ignore committees of inquiry, whereas conversely the then Irish Minister for Agriculture and President-in-Office of the Council made himself available to the BSE committee as a witness.

\subsubsection{The fall of the Santer Commission: a missed opportunity?}

In 1999, when allegations were made regarding fraud, mismanagement and nepotism in the European Commission, the Parliament did not establish a parliamentary committee of inquiry but delegated its supervisory power to an extra-parliamentary Committee of Independent Experts which was not constituted under any precise institutional regulation and which had no formal

\footnotetext{
499 European Parliament (1997). Transit committee. Chairman's report on the working methods of the Committee of Inquiry into the Community Transit System (PE 220.696/rev., 21.2.1997), p. 6.

${ }^{500}$ Ibid. p. 4.
} 
investigative powers. Lequesne and Rivaud concluded in clear terms: "the creation of the Committees of Independent Experts is the direct result of the EP's inability to bring into play the formal mechanisms of parliamentary control - the right of censure and the Temporary Committees of Inquiry" "501. A question which remains to be answered in this chapter is why the Parliament refrained from establishing a committee of inquiry even though it appears it was a suitable occasion for the establishment of such a committee.

One reason was practicality. The decision to set up a committee of independent experts was taken in January 1999, less than six months before the European Parliament elections in June 1999. The fact that inquiries may not extend into a consecutive legislative term meant that a committee of inquiry would only have had approximately five months in which to conduct an inquiry, which is fairly short given the parliamentary agenda. Walter van Gerven, one of the five independent experts, further noted that another reason was a 'political deadlock' at the time between the two major political parties. ${ }^{502}$ Shackleton, who acknowledged that there were tensions within Parliament, added: "political groups were reluctant to stick their nose into affairs of the Commission where the likelihood was that one particular political family would be touched. That made it more difficult to do. Establishing an external committee therefore seemed like an easier option". ${ }^{503}$

Although setting up a parliamentary committee of inquiry would have been favourable from the perspective of democratic accountability, it would be too easy to describe the establishment of the Committee of Independent Experts as a missed opportunity. Had the Parliament set up a committee of inquiry, this committee would have had little time to come up with its conclusions. It is highly doubtful whether a committee of inquiry would have been able to finish the job within this timeframe and given the tensions within Parliament, it is similarly doubtful whether a committee of inquiry would have been able to draft a solid and credible report based on broad consensus in the Parliament. The decision to set up a Committee of Independent Experts thus was a reasonable decision after all.

\subsection{The future shape of the right of inquiry}

So far this chapter has addressed the current legal position of committees of inquiry and the practice of the right of inquiry from 1993 until the present. This section reflects on the question of whether and, if so, how, the legal position of committees of inquiry should be strengthened, and addresses proposals that have been made to date.

\footnotetext{
501 Lequesne/Rivaud (2003), p. 707; Van Gerven, who regretted that no committee of inquiry was established, suggested that the procedure of Article 193 EC Treaty (at present: Article 226 TFEU) was not followed because of a "political deadlock" at the time between the two major political parties, cf: Van Gerven (2009), p. 120.

${ }^{502} C f$. Van Gerven (2009), p. 120.

${ }^{503}$ Interview with Michael Shackleton, 15 April 2010.
} 


\subsubsection{Should the right of inquiry be strengthened?}

This chapter has revealed several bottlenecks regarding the legal position of committees of inquiry. It has been concluded that, in a formal legal sense, the right of inquiry is rather weak. However, despite this de jure weak position, committees of inquiry have proved to be in a de facto rather strong position vis$\grave{a}$-vis the European Commission. Relations with authorities at the Member State level have proved problematic, both de jure and de facto. With this in mind, it would perhaps be tempting to recommend that committees of inquiry be equipped with stronger legal powers vis-à-vis all EU executive actors, both at the European level and at the Member State level. However, such a recommendation would pass over constitutional and democratic objections too easily.

A fundamental question is which executive actors the European Parliament should hold to account. In view of its direct democratic legitimacy at the European level, it is reasonable to assume that the European Parliament is the principal actor that should hold actors with executive powers at the European level (such as the Commission, the Council, the European Council, EU agencies and the ECB) to political account. The situation is, however, somewhat different regarding executive actors at the national level, notably national governments. They are in the first place accountable to 'their' respective national parliaments. It follows that the European Parliament should not be overambitious when it comes to holding them to account. Rather, it should engage the principal forums in this perspective, the national parliaments, if it wishes to hold national authorities to account. The powers of inquiry vis-à-vis executive actors at the national level thus should not be amended radically.

The situation is different for the legal position of committees of inquiry vis-àvis executive actors at the European level. The de jure weak position of committees of inquiry vis-à-vis these executive actors should be strengthened. The following modifications should be made to the provisions regarding the right of inquiry:

\section{Sub judice rule}

Article 226 TFEU stipulates that committees of inquiry may not investigate 'alleged facts' which are being examined by a court at the Member State level or at the EU level. This broadly formulated sub judice rule has the potential to paralyse the right of inquiry. A simple claim for damages before a national court regarding 'alleged facts' may frustrate the establishment of a committee of inquiry on these 'alleged facts'.

A fair balance should be struck between, on the one hand, the rationale of the sub judice rule (the doctrine of separation of powers), and on the other hand, the ability of the Parliament to hold an inquiry into alleged abuses in the EU sphere. Therefore, the sub judice rule should be redefined in the TFEU. A more balanced wording of the sub judice rule would be: 'Committees of inquiry may not enter into concrete legal questions which are simultaneously being considered by a court of law'. This wording mitigates the risk that the right of inquiry is paralysed too easily, while at the same time observing the doctrine of separation of powers. 


\section{Right of summons}

In order to fulfil its task of holding EU actors to account through inquiries, committees of inquiry should be able to gather evidence from any person working for these actors. Inquiry committees should therefore be given a right to summon any person working directly for the EU at the European level, ranging from members of the Commission, the President of the European Council and the President-in-office of the Council to administrators working for the European Central Bank or EU agencies. It should be noted that the European Ombudsman, who is elected by the Parliament, already has a right of summons vis-à-vis all officials and other servants of EU authorities.

The current provisions concerning the invitation of officials and servants of a national Member State, as well as the provisions concerning the invitation of members of national governments, should be extended with a duty to inform committees of inquiry extensively of the reasons for any refusal to appear before it.

\section{Questioning of witnesses}

In order to increase the reliability of evidence given, the right of summons should be combined with the possibility for committees of inquiry to swear in witnesses. The witnesses who have specific inside information on alleged abuses under investigation are generally officials and servants. Access to their information is therefore of vital importance for committees of inquiry. Under the current Interinstitutional Agreement, officials and servants testify on behalf of and as instructed by their governments or institutions. In order to prevent these witnesses from concealing relevant information from committees of inquiry, they should be bound to testify on their own authority.

\section{Access to documents}

Executive actors should be discouraged from concealing information from committees of inquiry by issuing a blanket claim that information is too sensitive to be forwarded. To this end, arrangements should be made which ensure that committees of inquiry are informed of why information cannot be forwarded to them without running the risk of making sensitive information, such as state secrets, available to the public.

The President of the European Parliament could be given a mediating role in this respect. If authorities do not want to provide committees of inquiry with information because of its sensitive nature, they should be under a duty to inform the President of the Parliament of the reasons for this. The President of the Parliament may try to find a solution, for example by proposing that the sensitive parts are withheld and the rest is forwarded to the committee of inquiry. If the authorities insist on concealing the information from the committee of inquiry, the President of the Parliament should verify the correctness of that decision in the light of the provisions on access to documents, without necessarily divulging the grounds for the decision.

Furthermore, committees of inquiry could discuss the conditions for the treatment of classified information covered by obligations of professional secrecy in advance with the authorities in question. It is, for example, conceivable that an executive actor forwards specific information to a 
committee of inquiry (or only to some of its members) on the condition that this information remains confidential.

\section{Public proceedings}

With a view to optimizing the public character of inquiries, the current unilateral right of witnesses to testify in camera should be abolished, as it is appropriate to give committees of inquiry, not the witnesses, the final say over the organization of inquiry proceedings.

\section{Fact finding visits}

Although, as a rule, committees of inquiry undertake on-the-spot fact-finding visits in the course of their inquiries, the current Interinstitutional Agreement on the right of inquiry is silent on the issue. The ability of committees of inquiry to conduct fact-finding visits should be provided for explicitly.

\section{Quick access to the CJEU}

Committees of inquiry should not only be equipped with extra powers, but there should also be a mechanism for them to call on the CJEU directly when they consider that their rights have been infringed. Executive actors should be discouraged from deploying blocking tactics, such as responding slowly to requests for documents, against committees of inquiry. Such tactics may hinder the work of committees of inquiry substantially, given the fact that they are generally under the time pressure of their temporary mandate. The CJEU should therefore deal with such requests of committees of inquiry quickly, in order to enable committees of inquiry to conduct their investigations.

\section{Legal protection}

Particularly if committees of inquiry are to gain stronger powers vis-à-vis witnesses in the future, the need to lay down explicitly the rights of these witnesses grows. The rights of witnesses, such as the right to legal assistance and the duty to inform witnesses of their rights and obligations, should be laid down explicitly in order to safeguard the rights of witnesses.

Executive actors and (natural and legal) persons under investigation should have the opportunity to contest directly decisions of committees of inquiry by submitting a complaint to the Parliament. If the Parliament refuses the objection or fails to take a timely decision, it should be possible to make a direct appeal to the CJEU to request a judgement on the lawfulness of a decision of the committee of inquiry.

\subsubsection{Proposed modifications to the right of inquiry}

The pre-Lisbon Article 193 EC Treaty stipulated that the detailed provisions governing the exercise of the right of inquiry were to be determined by common accord between the Parliament, the Council and the Commission. The Lisbon Treaty has granted the Parliament an exclusive right of initiative on this subject. The third sentence of Article 226 TFEU reads: 'The detailed provisions governing the exercise of the right of inquiry shall be determined by the European Parliament, acting by means of regulations on its own initiative in accordance with a special legislative procedure, after obtaining the consent 
of the Council and the Commission'.504 On 30 November 2009, one day before the Lisbon Treaty entered into force, the British Labour MEP David Martin was appointed as rapporteur to prepare such a regulation on the right of inquiry, which would repeal and replace the 1995 Interinstitutional Agreement. Almost two years later, in October 2011, the committee on Constitutional Affairs adopted a report entailing a proposal to adopt a new regulation on the right of inquiry of the European Parliament. ${ }^{505}$ The Draft Proposal was subsequently debated in plenary on 23 May 2012. In view of likely resistance from the Council and Commission, the plenary amended single provisions of the Draft Proposal of 2011 and postponed the vote on the final text in order to leave a margin of maneuver for negotiations to continue with the Council and Commission. ${ }^{506}$

The draft report of 2011 gives three reasons for the need to modify Parliament's right of inquiry: the experiences of former committees of inquiry, the renewed procedure of Article $226 \mathrm{TFEU}$, and the fact that the European Ombudsman and national parliaments have broader powers than committees of inquiry. ${ }^{507}$ Whereas the latter two reasons do not seem persuasive, the first reason - the experiences of former inquiry committees - is more interesting. It is, however, disappointing that the explanation does not reach any further than a mere reference to one of the conclusions of the committee of inquiry which investigated the collapse of the Equitable Life Assurance Society. ${ }^{508}$ The following sub-sections discuss single aspects of David Martin's Draft Proposal. In order to expedite comparisons, the individual aspects of the proposed regulation (hereafter: 'Draft Proposal') are discussed in the same order as in the Interinstitutional Agreement discussed in Section 2.4.

\subsubsection{The scope of the right of inquiry}

The scope of the right of inquiry is laid down in Article 226 TFEU. As a Treaty provision cannot be amended by a regulation (Lex superior derogate legi inferiori), it is not surprising that the Draft Proposal does not contain proposals to extend or restrict the scope of the right of inquiry. The Draft Proposal does, however, contain a novelty regarding the sub judice rule. At present, the European Parliament may not establish a committee of inquiry if at the same time (i.e. at the moment of establishment) legal proceedings are ongoing on the same facts before a national or a Union court. ${ }^{509}$ Article 5 (2) Draft Proposal is intended to enable the European Parliament - without being legally obliged to

\footnotetext{
${ }^{504}$ Section 2.3.2 discusses this amendment and its implications in more detail.

${ }^{505}$ European Parliament (2011). AFCO committee. Report on a proposal for a regulation of the European Parliament on the detailed provisions governing the exercise of the European Parliament's right of inquiry and repealing Decision 95/167/EC, Euratom, ECSC of the European Parliament, the Council and the Commission (A7-0352/2011, 14.10.2011).

${ }^{506}$ Cf. Sebag (2012).

${ }^{507}$ European Parliament (2011). AFCO committee. Report on a proposal for a regulation of the European Parliament on the detailed provisions governing the exercise of the European Parliament's right of inquiry and repealing Decision 95/167/EC, Euratom, ECSC of the European Parliament, the Council and the Commission (A7-0352/2011, 14.10.2011), pp. 2527.

${ }^{508}$ Ibid. p. 26.

${ }^{509} \mathrm{Cf}$. Section 2.4.3.1 regarding the sub judice rule.
} 
do so - to suspend the investigation of a committee of inquiry if, after it has been set up, legal proceedings concerning the same subject are initiated. This might seem to be merely a codification of the existing situation, as the Parliament may, of course, suspend its own inquiry activities at any time. However, it actually is a modification, as Article 5 (2) Draft Proposal stipulates that time that passes while an inquiry is suspended does not count towards the time within which the committee of inquiry has to submit its report. Hence, this proposed modification enables Parliament to serve the independence of the judiciary - by not prejudging its work in Parliament - without, however, taking precious time from a committee of inquiry to conclude its work.

\subsubsection{The powers of committees of inquiry}

The Draft Proposal includes substantially stronger powers for committees of inquiry than those under the Interinstitutional Agreement.

\section{The right to call witnesses}

Article 15 (1) Draft Proposal stipulates that committees of inquiry 'may request any person who is resident in the Union to participate in a hearing before it, if this is necessary in order for it to be able to fulfill its tasks'. The first paragraph of this article reads: 'In accordance with the principle of sincere cooperation and the relevant legal provisions, the competent national authority shall summon the individual to appear before the committee of inquiry'. Article 15 (1) Draft Proposal leaves many questions unanswered. Its wording does not place individuals directly under a duty to appear before committees of inquiry, as these persons may only be 'requested' to give evidence to a committee of inquiry. However, the 'competent national authority' is put under an obligation to summon such individuals, in accordance with the principle of sincere cooperation and the relevant legal provisions'. It is foreseeable that this provision (if it enters into force) will lead to overall confusion and to conflicts between committees of inquiry and both EU and national authorities as to whether persons invited on the basis of Article 15 (1) Draft Proposal are under a legal duty to appear and whether national authorities are under a legal duty to cooperate in accordance with the principle of sincere cooperation and the relevant legal provisions'. The current wording seems to denote a far-reaching general right of summons, via national authorities, vis-à-vis any person who is resident in the European Union.

Under Article 16 Draft Proposal, 'committees of inquiry may invite the institutions of the Union, with the exception of the Court of Justice of the European Union, or governments of Member States to designate one or more of their members to take part in its proceedings if their testimony is considered to be of material importance and necessary for a thorough appraisal of the matter under investigation'. This provision is similar to Article 3 (2) of the Interinstitutional Agreement of 1995..$^{510}$

In comparison to Article 3 (3) of the Interinstitutional Agreement of 1995, the right to invite officials and other servants to testify before committees of inquiry has been extended. On the basis of Article 17 (2), committees of inquiry

${ }^{510}$ Cf. Section 2.4.4.1. 
may summon specific officials or other servants of the Union. The rapporteur, Martin (S\&D), defended this novelty by stating: "what we want is to be able to get to the appropriate desk officer, who sometimes has information that higher ups do not want to know or do not know". ${ }^{511}$ If the official or other servant concerned is not authorized to obey the summons from the committee to attend for examination and to submit statements and give evidence in person, than the official or authority responsible for denying the authorization shall appear before the committee of inquiry to explain the reasons for this. If Member States fail to designate an official upon a request by a committee of inquiry, Article 17 (4) provides that a representative authorized to commit the government of the Member State concerned shall appear before the committee and shall explain the reasons for this.

Article 16 and 17 of the Draft Proposal thus do not bring fundamental changes to the existing regime under the Interinstitutional Agreement of 1995. The question remains, however, how Article 15 should be interpreted. This provision does not include exceptions and it is thus also applicable to the categories of witnesses of Article 16 and 17 Draft Proposal. The current wording seems to denote a general right of summons, via national authorities, $v i s$-à-vis any person who is resident in the European Union. In view of the farreaching consequences such a power may have, the least that may be demanded is a further explanation of the exact meaning of Article 15 Draft Proposal.

\section{The legal position of witnesses}

The legal position of witnesses summoned under Article 15 (1) Draft Proposal is provided for in Article 15 (2) Draft Proposal in general terms: 'Individuals shall willingly, fully and truthfully answer questions put to them by members of the committee of inquiry. They may claim the right to refuse to give evidence which they would enjoy if requested to be heard by a parliamentary committee of inquiry or similar body in their Member State of residence or, in the absence of such committee or body, in the Member State where the hearing is held. Individuals shall be informed in advance of their rights and obligations and of the possible consequences of groundless refusal of the request to be heard, of giving false evidence and of the bribing of individuals'.

Contrary to the initial Draft Proposal of 2011, the Draft Proposal of 2012 does not contain an explicit provision for witnesses to be heard under oath, nor that they have the right to avail themselves of legal counsel. ${ }^{512}$ Article 6 of the Draft Proposal of 2012, however, does bring an end to the remarkable unilateral right of witnesses under the Interinstitutional Agreement of 1995 to testify in camera.

\footnotetext{
${ }^{511}$ Cf. Sebag (2012).

${ }^{512} C f$. Article 15 (2) and 15 (4) Draft Proposal 2011. Cf. European Parliament (2011). AFCO committee. Report on a proposal for a regulation of the European Parliament on the detailed provisions governing the exercise of the European Parliament's right of inquiry and repealing Decision 95/167/EC, Euratom, ECSC of the European Parliament, the Council and the Commission (A7-0352/2011, 14.10.2011).
} 


\section{Access to documents}

Like the Interinstitutional Agreement, the Draft Proposal stipulates that both EU authorities and national authorities are under a legal duty to make relevant documents available to committees of inquiry on the latter's request ( $c f$. Article 14 Draft Proposal). The Draft Proposal includes no explicit exceptions on this general duty for EU institutions, but it does list explicit exceptions for Member States' authorities. It follows from Article 14 (2) Draft Proposal that Member States' authorities may refuse to forward documents to committees of inquiry if that would run counter to provisions of national law or to the rules set out in Article 346 (1a) and 346 (1b) TFEU (for the sake of protecting national security).

The Draft Proposal's provision on access to documents goes further in that it equips committees of inquiry with a right to compel legal or natural persons to forward documents to it. These legal or natural persons may claim the rights 'they would enjoy under national legislation in the case of seizure of objects by national law-enforcement authorities' (Article 14 (3) Draft Proposal).

\section{Fact-finding visits}

The informal practice of on-the-spot fact-finding visits by committees of inquiry has found its way into the Draft Proposal. Article 13 Draft Proposal stipulates that fact-finding visits 'shall be conducted where appropriate in cooperation with the national authorities, in conformity with the provisions of national law'. This provision lacks clarity and it therefore bears the inherent risk that it will lead to conflicts of interpretation. It is, for example, unclear whether national authorities are under a legal duty to cooperate and it remains unclear which provisions of national law are meant in Article 13 Draft Proposal. This could be merely the provisions regarding fact-finding visits by parliamentary committees of inquiry, but it could also imply such visits by judicial and police authorities.

\section{Sanctions}

A major difference with the Interinstitutional Agreement is that the Draft Proposal includes a sanction mechanism, albeit an indirect one. Article 19 (2) Draft Proposal lists four infringements which shall be penalized by Member States under their national law: (1) groundless refusal to provide any documents requested; (2) groundless refusal by individuals of the request to be heard; (3) the giving of false evidence; and (4) the bribing of individuals. Article 19 (3) Draft Proposal puts Member States under a legal duty to bring proceedings (under national law) against persons who are reasonably suspected of having committed one of these infringements. The question arises how Member States can fulfil this positive obligation if these infringements are not punishable acts according to national law. It is further remarkable that it is not intended that a groundless refusal to give evidence (by means of remaining silent) should be punished, even though Article 15 (2) Draft Proposal obliges witnesses to answer questions 'willingly, fully, and truthfully'. 


\subsubsection{Legal protection in the course of inquiries}

It goes without saying that strong powers require appropriate legal remedies against the use of these powers. The Draft Proposal contains no novelties in this regard. Authorities and legal and natural persons who want to contest a decision to establish a committee of inquiry, or who wish to appeal against single decisions by inquiry committees, should thus resort to the general action for annulment as laid down in Article 263 TFEU. ${ }^{513}$

\subsubsection{Remarks on the proposed modifications}

Although the Draft Proposal of 2012 is fairly ambitious, it is not as farreaching as the Draft Proposal of 2011. With the proposal of 2011, the rapporteur, David Martin, seemed to embrace the negotiation tactic of starting high and hoping that in the end some of the proposals would survive. In this sense, the situation is similar to that shortly after the entry into force of the Maastricht Treaty when the European Parliament proposed strong powers for committees of inquiry but when the Council put a stop to this. ${ }^{514}$ One can only speculate which parts of the current proposal will ultimately survive, but it was highly unlikely that the Commission and the Council (under qualitative majority voting) would agree in full with David Martin's proposal of 2011. The less ambitious Draft Proposal of 2012 demonstrates that some of the initial ideas have already been eliminated after interinstitutional deliberations on this issue. In particular, the initial proposals regarding strong powers of committees of inquiry vis-à-vis persons and authorities at the Member State level have, undoubtedly under pressure from the Council, been weakened in the 2012 Draft Proposal. The proposed powers vis-à-vis persons and authorities at the Union level, on the contrary, may very well survive the interinstitutional negotiations. At present, the European Ombudsman has stronger investigative powers vis-à-vis persons and authorities at the Union level than committees of inquiry of the European Parliament. The European Ombudsman can summon any official and servant of the European Union to testify before him and EU authorities are obliged to supply the Ombudsman with any information he has requested from them. ${ }^{515}$ It would be reasonable to bring the powers of committees of inquiry of the directly elected European Parliament at least into line with the powers of the European Ombudsman, who is appointed by the European Parliament.

From a legal perspective, the question arises whether the far-reaching powers for committees of inquiry, as proposed by the European Parliament, can actually be based on the Treaties. This is particularly the case for the strong powers which are foreseen for committees of inquiry vis-à-vis Member State authorities and vis-à-vis legal and natural persons. Article 5 TEU lays down the principle of conferral, which implies that the Union shall act only within

\footnotetext{
${ }^{513}$ Cf. Section 2.4.5.

514. Cf. Section 2.3.2.

515 Cf. Article 3 (2) of the European Ombudsman Statute. The European Ombudsman Statute was adopted by Parliament on 9 March 1994 (OJ L 113, 4.5.1994, p. 15) and amended by its decisions of 14 March 2002 (OJ L 92, 9.4.2002, p. 13) and 18 June 2008 (OJ L 189, 17.7.2008, p. 25).
} 
the limits of the competences conferred upon it by the Member States in the Treaties to attain the objectives set out therein', and that 'competences not conferred upon the Union in the Treaties remain with the Member States'. Article 226 TFEU clearly confers the competence to adopt a regulation regarding the powers of committees of inquiry to the Union, notably the Parliament, the Council and the Commission. ${ }^{516}$ However, it is open to doubt whether the current parliamentary proposal is compatible with two other principles which are laid down in Article 5 TEU: the principles of subsidiarity and proportionality. Under the principle of subsidiarity, the Union shall act only if and in so far as the objectives of the proposed action cannot be sufficiently achieved by the Member States (Article 5 (3) TEU). The task of examining alleged abuses in the implementation of Union law does not fall within the exclusive competence of the European Union. It is clear that national parliaments are not in a position to hold executive actors at the European level, such as the Commission and the Council, to account for alleged abuses in the context of EU law. However, it is far from evident that national executive actors, such as national governments, cannot be held to account for alleged abuses in the EU context by national accountability forums, such as national parliaments. There is no direct accountability relationship between the European Parliament and national executive actors. As national governments are created, be it directly or indirectly, via national parliamentary elections, it follows that they are in the first place politically accountable to 'their' respective national parliaments. The same argument is applicable to other executive actors at the national level, such as national independent agencies and regional and local governments. They are first and foremost accountable to national accountability forums, including for alleged abuses in the context of EU law. From a subsidiarity perspective, the proposal to equip committees of inquiry of the European Parliament with strong powers vis-à-vis national executive actors must thus be regarded critically. It therefore is a pity that the European Parliament proposal is completely silent on its compatibility with the principle of subsidiarity. The least that could have been expected from the Parliament would have been an explanation of why the objective of holding national executive actors to account for alleged abuses in the EU context can be better achieved by the European Parliament than by national accountability forums.

Furthermore, it is doubtful whether the proposal of the European Parliament can pass the proportionality test. Under the principle of proportionality, the content and form of Union action shall not exceed what is necessary to achieve the objectives of the Treaties (Article 5 (4) TEU). In its explanatory statement, the European Parliament argues that the proposed powers are necessary in order to base the conclusions of inquiries "solely on elements which have evidential value". ${ }^{517}$ Unfortunately, the Parliament gives no solid explanation

516 The last sentence of this provision stipulates: "The detailed provisions governing the exercise of the right of inquiry shall be determined by the European Parliament, acting by means of regulations on its own initiative in accordance with a special legislative procedure, after obtaining the consent of the Council and the Commission."

517 European Parliament (2011). AFCO committee. Report on a proposal for a regulation of the European Parliament on the detailed provisions governing the exercise of the European 
of why it deems the specific powers both necessary and proportional to investigate alleged contraventions or maladministration in the implementation of Union law. This is particularly problematic considering the strong powers vis-à-vis legal and natural persons. Whereas it might be understandable that the Parliament wants to have firm powers to gather evidence from executive actors, this is somewhat different for legal and natural persons. Legal and natural persons may be considered 'third parties' in relation to the accountability forum (the European Parliament) and the several accountability actors which can be held to account under Article 226 TFEU. ${ }^{518}$ Even though third parties as such cannot implement Union law, and as a consequence they cannot be the subject of an inquiry, the Parliament wants to have strong powers to gather information from them. Under the European Parliament's proposal, any legal and natural person can be obliged to give oral and written evidence to committees of inquiry if the Parliament deems it necessary. This far-reaching proposal seems disproportional and incompatible with Article 5 (4) TEU. It is therefore regrettable that the European Parliament does not elaborate further on why it apparently believes that this proposal is in accordance with the principle of proportionality.

There are other aspects which should be assessed critically. At several points the Draft Proposal stipulates that national authorities are under an obligation to assist committees of inquiry in the course of their investigations. An example of such an obligation is the duty to assist committees of inquiry when they conduct on-the-spot fact-finding visits (Article 13 Draft Proposal). It remains unclear how this provisions should be implemented in practice. A question which remains unanswered is whether national authorities are given discretion to assess whether they were rightfully ordered to assist a committee of inquiry of the European Parliament, or whether national authorities are under an automatic duty to execute any order which they receive to this end from committees of inquiry of the European Parliament.

The parliamentary proposal on a new regulation regarding the right of inquiry leaves many further questions unanswered. Many of these questions are the consequence of the vague wording of the Draft Proposal. The Draft Proposal refers occasionally to the principle of sincere cooperation. It is foreseeable that this will lead to conflicts between committees of inquiry and both EU and national authorities on the concrete interpretation of this principle. However, it seems to be a necessary compromise between the European Parliament on the one hand, and the Council and the Commission, on the other. With the current compromise, both camps probably feel confident enough to plea their respective cases. Whereas Parliament will claim that the Draft Proposal obliges authorities and legal and natural persons to cooperate in the course of inquiries, the Council and the Commission may claim the opposite.

Furthermore, national law is at several points declared mutatis mutandis applicable to the proceedings of committees of inquiry of the European Parliament. ${ }^{519}$ It goes without saying that this will lead to legal inequality as

Parliament's right of inquiry and repealing Decision 95/167/EC, Euratom, ECSC of the European Parliament, the Council and the Commission (A7-0352/2011, 14.10.2011), p. 28.

${ }^{518}$ Cf. Section 2.4.3.2.

${ }_{519}$ See for example Articles 13, 14 (2), 19 (2), and 19 (3) of the Draft Proposal 2012. 
national laws vary from Member State to Member State. The Draft Proposal, however, unfortunately does not discuss this issue.

\subsection{Conclusion}

This chapter has discussed the right of inquiry of the European Parliament. The legal position of committees of inquiry has been analyzed and the three inquiries conducted since 1993 have been examined.

\section{Inquiry powers}

Unlike their counterparts in many Member States, committees of inquiry of the European Parliament have rather limited powers of investigation. Under the current legal provisions, committees of inquiry have no general right of summons, witnesses have a unilateral right to provide testimony in camera, they cannot be heard under oath and there are no means to sanction false testimonies. Furthermore, committees of inquiry practically depend on the willingness of executive actors to forward relevant documents to them and the scope of the right of inquiry is restricted. The three inquiries carried out so far have shown that the legal limitations placed on committees of inquiry have effectively hampered their work. The committees experienced difficulties in ensuring the attendance of witnesses they wanted to hear and in ensuring access to relevant documents.

On the basis of the findings, concrete recommendations to reinforce the legal position of committees of inquiry have been formulated ( $c f$. Section 2.6.1). These proposals include an amendment to the sub judice rule, which is currently formulated too widely. A more balanced wording has been proposed in order to prevent the risk that the right of inquiry could be easily paralyzed by the application of the current sub judice rule. A proposal has also been made to give committees of inquiry a right of summons vis-à-vis any person working directly for executive actors at the EU level, ranging from members of the Commission and the President of the European Council to administrators working for the European Central Bank or EU agencies. In order to increase the reliability of evidence given, the right of summons should also be combined with the ability of committees of inquiry to swear in such witnesses and the current unilateral right of witnesses to testify in camera should be abolished. Executive actors tend to make use of their right to conceal sensitive information from committees of inquiry by referring to reasons of secrecy or public or national security. In order to discourage executive actors from abusing this right, an arrangement should be created which on the one hand ensures that the Parliament is properly informed of the reasons why information cannot be forwarded to it, without, on the other hand, running the risk of making sensitive information available to the public. A proposal has been put forward to assign the President of the European Parliament a mediating role in such cases. The regularly used opportunity for committees of inquiry to conduct fact-finding visits should be provided for explicitly and committees of inquiry should be given direct formal mechanisms to penalize breaches of their rights. Furthermore, committees of inquiry should not only be equipped with extra powers, but there should also be a mechanism for them to call on the CJEU directly when they consider that their rights have been 
infringed. Executive actors should be discouraged from deploying blocking tactics, such as responding slowly to requests for documents, against committees of inquiry. Such tactics may hinder the work of committees of inquiry substantially, given the fact that they generally work under the time pressure of their temporary mandate. The CJEU should therefore deal with such requests of committees of inquiry quickly, in order to enable committees of inquiry to conduct their investigations. Executive actors and persons under investigation should have the ability to contest decisions by the committees of inquiry immediately before the CJEU and the rights of witnesses appearing before committees of inquiry should be laid down explicitly.

These recommendations are principally aimed at strengthening the legal position of committees of inquiry vis-à-vis executive actors at the European level, and not at the national level. The reason for this is that executive actors at the national level should first and foremost be accountable to accountability forums at the national level. The European Parliament does not seem to share this belief, as it has made proposals to give committees of inquiry strong powers both vis-à-vis executive actors at the European level and vis-à-vis executive actors at the national level. The proposals of the European Parliament, as discussed in Section 2.6.2, include a right of summons (via national authorities) vis-à-vis any person residing in the European Union and it include strong powers regarding inter alia the hearing of witnesses, access to documents and on-the-spot fact-finding visits.

\section{Beyond formal powers}

According to the rapporteur, David Martin $(\mathrm{S} \& \mathrm{D})$, the proposals of the European Parliament appear "appropriate enough to ensure that the political control exercised by the European Parliament - the only directly elected Union institution - is ultimately serious, efficient and in line with the European citizens' expectations of democratic accountability and good governance" ${ }^{520}$ However, the rapporteur jumps to conclusions too easily, as this chapter has shown that there are other important factors which determine the strength of the right of inquiry.

The strength of the right of inquiry also depends on the way in which the Parliament makes use of this instrument. The three committees of inquiry proceeded according to a meticulous working method and they proved able to substantiate their conclusions on the basis of facts rather than on the basis of biased positions, which certainly had a positive influence on the credibility and legitimacy of their final reports. It goes without saying that committees of inquiry are political bodies - i.e. not judicial bodies - and that an inquiry is consequently a political event. However, none of the three inquiries was hijacked by political disputes between the political groups represented on the inquiry committees. The fact that the final reports of the three committees were adopted by a large majority (including the two largest groups) in plenary

\footnotetext{
${ }^{520}$ European Parliament (2011). AFCO committee. Report on a proposal for a regulation of the European Parliament on the detailed provisions governing the exercise of the European Parliament's right of inquiry and repealing Decision 95/167/EC, Euratom, ECSC of the European Parliament, the Council and the Commission (A7-0352/2011, 14.10.2011), p. 29.
} 
further demonstrates the political groups' willingness to accept compromises and their determination to remedy the shortcomings which had come to light in the course of the inquiries. The support of a large majority of the plenary is particularly important with regard to the follow-up to an inquiry. A coincidental majority does not suffice if the Parliament really wants to achieve something, as only an overwhelming majority will be taken seriously by the Commission and the Council.

Another aspect which influences the success of an inquiry and which should not be underestimated is the level of publicity given to an inquiry. Wide publicity ensures that executive actors are held to public account. Hence, executive actors run the risk of suffering a loss of face if they do not cooperate properly in the course of an inquiry. It has been proposed that committees of inquiry be given powers to summon and swear in witnesses, but that is still not a guarantee that witnesses will provide inquiry committees with useful information. The pressure on witnesses to give a true statement may be assumed to be considerably higher if the witnesses know that they will be held to public account. The same is true for access to documents, as publicity raises the pressure to forward documents which authorities perhaps initially do not want to release. The BSE inquiry is an example of a case where publicity made formal inquiry powers almost superfluous. The BSE case generated wide publicity due to the concerns of meat-eaters all over Europe regarding the quality of the meat they were consuming. Journalists became interested in the BSE issue and, as well as other persons, passed on relevant information to the BSE committee. Some of these sources preferred to remain anonymous. However, their information certainly led the BSE committee in the right direction by steering the questioning of witnesses and requests for documents, as this information enabled the inquiry committee to put specific questions to witnesses and to ask for specific documents pointed out by sources to the inquiry committee. The degree of publicity given to an inquiry should thus not be underestimated as a factor which influences the success of an inquiry. Wider publicity increases the chance that relevant information finds its way to a committee of inquiry, which makes it more difficult for executive actors to disguise the real facts and to ignore recommendations for the future as formulated in the final committee reports.

An important indicator for determining the success of an inquiry is the impact it has on the issue under investigation. Despite the legal constraints, the inquiries held to date have had a considerable impact in their respective domains. Besides putting the respective issues on the agenda, the inquiries had an effect beyond the conclusion of the final reports and the issues remained on the political agenda even after the committees of inquiry ceased to exist. Furthermore, especially in the Transit and BSE cases, the inquiries led to concrete changes in policy and legislation which almost certainly would not have happened had the inquiries not been conducted.

\section{The right of inquiry as an accountability instrument}

The European Parliament has proved able to use its right of inquiry as a means of holding the Commission to account for its actions. The BSE inquiry is a particularly clear example of an accountability forum holding an accountability 
actor to account. At the same time, however, the inquiries into BSE and, particularly, Equitable Life have shown that there is a downside to this apparent success story. These inquiries demonstrated that committees of inquiry concentrate mainly on the Commission even though other executive actors (notably the Council and individual Member States) may be more to blame for the events under investigation. In both the BSE case and the Equitable Life case, the Commission was called to account for abuses for which mainly one Member State (the United Kingdom) and the Council were responsible. The growing parliamentary control over the Commission has thus had the perverse effect of creating mismatches between those actually responsible and those held to account. One could think that the explanation for this phenomenon is based on the (valid) belief that it is in the first place up to national parliaments - and not the European Parliament - to hold national governments to account. However, the Parliament's proposals on the future right of inquiry rather suggest that it does indeed want to hold national authorities directly to account. Thus in all probability it was not the subsidiarity principle which stood in the way of calling Member States and the Council to account, but the Parliament's ambition to make success stories out of their inquiries. The Parliament is conscious of the fact that a successful outcome of an inquiry is more likely if it concentrates mainly on the Commission. Had the main focus of the committee of inquiry into BSE been on the United Kingdom and the Council, then the BSE inquiry would probably have been substantially less successful. The committees of inquiry into BSE and Equitable Life did attempt to hold the United Kingdom and the Council to account for their actions, but they constantly came up against a wall of resistance with national ministers and national civil servants refusing to appear before the committees and relevant documents being concealed from them. The explanation for this lack of cooperation was a combination of, firstly, a British sense that the European Parliament should not stick its nose into their affairs, and secondly, a lack of incentives to cooperate with the inquiry committees. The Commission and the European Parliament depend on each other to a large extent to achieve their goals. In the course of the BSE case, the Parliament made clever use of this mutually dependency. After the committee of inquiry had adopted a report that was critical about the way the Commission had managed the BSE issue, the Parliament adopted a resolution calling on the Commission to take urgent and effective action to follow up on the report's recommendations and to implement without delay the measures formulated therein. In order to ensure that the recommendations were actually dealt with, the Parliament threatened to table a motion of censure against the Commission if it did not show improvements within six months. The Parliament established a temporary special committee to scrutinize the Commission's response. This conditional threat, in conjunction with the close scrutiny of the Commission, served to ensure that the Commission did indeed follow up on most of the recommendations made by the Parliament. Things are, however, quite different in the relationship between the European Parliament on the one hand, and the Council and individual Member States on the other, where it is hard to speak of mutual dependency and where incentives for the Council and Member States to cooperate are, as a consequence, considerably less self-evident. 
Despite the legal constraints, the European Parliament has shown that the right of inquiry can be a useful instrument to hold the Commission to account for its actions. At the same time, however, it proved difficult to hold the Council and individual Member States to account for their actions. As national parliaments are the appropriate democratic forum for holding 'their' respective national governments to account, it is by all means appropriate that the European Parliament show restraint when it comes to holding national governments (and other national authorities) to account. The situation in relation to the Council is different. Although national parliaments should hold national governments to account for their actions as part of the Council, none of them are able to hold the Council to account as such, it being a composition of 27 Member State governments. The Council should thus be held to political account by the European Parliament. Considering this, it is problematic that the Council proved untouchable for the European Parliament. 


\section{INVESTIGATIONS BY TEMPORARY SPECIAL COMMITTEES}

\subsection{Introduction}

Whereas only three committees of inquiry have been established since 1993, the Parliament has established twelve temporary special committees since 1993. This chapter will show that the Parliament uses its special committees for several purposes, including holding the executive to account. The question then arises why the Parliament did not choose to establish a temporary committee of inquiry when it set up a temporary special committee to investigate executive action. This chapter aims to answer this question and compares the proceedings for both types of temporary committee.

Firstly, Section 3.2 discusses the legal basis and the practice of special committees before the Treaty of Maastricht came into force in 1993. Section 3.3 considers the current legal framework within which special committees conduct their investigations. Subsequently, Section 3.4 addresses the chronological proceedings and individual aspects of investigations carried out by special committees. Section 3.5 examines the type of investigation conducted by every special committee established after 1993. The work of the special committees which conducted 'accountability investigations' is analyzed in Section 3.6. Section 3.7 looks at how these committees collected information in the course of their investigations. Conclusions are drawn in Section 3.8.

\subsection{Special committees prior to Maastricht}

This section briefly addresses the legal basis and the practice of special committees established before 1993, in the same way as Section 2.2 discusses the pre-Maastricht right of inquiry. Special committees have always had a basis in the Rules of Procedure of the European Parliament. Rule 91 of the 1981 Rules of Procedure stipulated: 'Parliament shall set up standing or temporary, general or special committees, and shall define their powers'. The Rules of Procedure were modified in 1987. From then on, temporary committees as mentioned in Rule 91 Rules of Procedure 1981 were governed by Rule 109 (2) Rules of Procedure 1987521, which read: 'Parliament may at any time set up temporary committees, whose powers, composition, and term of office shall be defined at the same time as the decision to set them up is taken; their term of office shall not exceed twelve months, except where Parliament extends that term on its expiry'. Unlike for the right of inquiry, the legal bases of special committees have never included a material restriction on the right to set up special committees. Whereas committees of inquiry could (and still can) only be established to investigate specific alleged abuses, special committees, by contrast, could (and still can) be established to investigate any matter the Parliament pleases.

\footnotetext{
${ }_{521}$ It should be noted that the special committees were shortly governed by Rule 91 (2) Rules of Procedure 1986 between 1986 and 1987. The wording of Rule 91 (2) Rules of Procedure 1986 is identical to the wording of Rule 109 (2) Rules of Procedure 1987.
} 
Between 1979 and 1993, special committees were generally set up to deal with political problems of general significance which required focused attention for a limited time. The main aim of these committees was to prepare future decisionmaking related to the matters under investigation. ${ }^{522}$ The investigations of these special committees thus correspond with the 'non-accountability investigations', discussed in Section 1.4.3.2. The Parliament established five such committees in the period between 1979 and 1993 (see Figure 3.1 below). ${ }^{523}$

\begin{tabular}{|l|l|}
\hline Year & Investigation \\
\hline 1983 & $\begin{array}{l}\text { European Economic Recovery. In 1983, the Parliament } \\
\text { commissioned two external experts to produce a report on ways to } \\
\text { stimulate European economic development. Parliament set up a } \\
\text { temporary committee to provide a follow-up to this report. }\end{array}$ \\
\hline 1984 & $\begin{array}{l}\text { Budgetary Resources. The Budgetary Resources committee was } \\
\text { established to examine the budgetary problems of the Community and } \\
\text { to take a stance on behalf of the Parliament on a communication from } \\
\text { the Commission regarding the Single European Act. }\end{array}$ \\
\hline 1987 & $\begin{array}{l}\text { Delors I Package. This committee was established to formulate the } \\
\text { Parliament's stance on the first 'Delors Package', the Commission } \\
\text { proposal for a multi-annual financial framework. }\end{array}$ \\
\hline 1990 & $\begin{array}{l}\text { Impact on the European Community of the German Unification. } \\
\text { This committee was established in response to the intended German } \\
\text { unification. The committee was made responsible for considering the } \\
\text { draft legislation necessary to permit the German unification. }\end{array}$ \\
$\begin{array}{l}\text { Delors II package. This committee was established to formulate the } \\
\text { Parliament's stance on the second 'Delors Package', the Commission } \\
\text { proposal for a multi-annual financial framework. }\end{array}$ \\
\hline
\end{tabular}

Figure 3.1 Investigations by special committees between 1979 and 1993

\subsection{Special committees since Maastricht; legal framework}

When the Treaty of Maastricht recognized the right of inquiry as primary law, the Parliament chose to retain the ability to establish special committees in its Rules of Procedure. The main reason for this was the limited scope of the committees of inquiry. ${ }^{524}$ The Parliament thus wanted to remain able to establish a temporary committee in cases where the restricted scope of the right of inquiry would stand in the way of setting up a temporary committee of inquiry. This has proved to be a wise decision. Whereas only three committees of inquiry have been established since 1993, the Parliament has set up twelve special committees in the same period.

In contrast with the right to set up committees of inquiry ex Article 226 TFEU, the establishment of special committees has no basis in the Treaties.

${ }^{522} C f$. Beckedorf (1995), p. 190; European Parliament (1982). Working document on the interpretation of Rule 95 of the Rules of Procedure (PE 80.257, 3.9.1982), p. 5.

${ }^{523}$ Cf. Costa (2001), pp. 166-167 and 218-219.

${ }^{524}$ Driessen (2007), p. 114; Wiersma (2004), p. 225. 
The sole basis for special committees is Rule 184 of the Rules of Procedure, which stipulates: 'On a proposal from the Conference of Presidents, Parliament may at any time set up special committees, whose powers, composition and term of office shall be defined at the same time as the decision to set them up is taken; their term of office may not exceed twelve months, except where Parliament extends that term on its expiry. As the powers, composition and term of office of special committees are decided at the same time as these committees are set up, Parliament cannot subsequently decide to alter their powers either by increasing or reducing them.'

Like committees of inquiry, special committees are set up by simple majority vote. ${ }^{525}$ The Interinstitutional Agreement on the right of inquiry provides for an additional layer of general powers of the European Parliament. Accordingly, committees of inquiry have powers (inter alia regarding the right to invite witnesses and access to documents) which other committees (temporary special committees and standing committees) do not have. ${ }^{526}$ Although special committees thus have fewer powers than committees of inquiry, their possible scope of investigation is broader. Whereas committees of inquiry may only be established in cases of 'alleged contraventions or maladministration' in the EU context, there is no explicit limitation to the scope of investigations carried out by special committees. Even the sub judice rule, according to which committees of inquiry may not investigate issues which are simultaneously being examined before a court of law, does not explicitly exist for special committees. ${ }^{527}$ Whether the European Parliament, in view of the separation of powers doctrine, should investigate matters which are sub judice, is another matter altogether. As the work of special committees can bear a strong resemblance to the work of committees of inquiry, it is reasonable to argue that the Parliament should exert restraint when establishing special committees on issues which are sub judice. Situations should be avoided where the Parliament establishes a special committee instead of a committee inquiry because the latter could not be set up due to the sub judice rule. In such cases, the rationale of the explicit sub judice rule regarding the right of inquiry would be undermined.

Special committees thus have fewer powers but, on the other hand, they encounter fewer formal restrictions and therefore appear to be more flexible. The wide scope of special committees represents a major advantage over committees of inquiry and their rather restricted scope. The committees of inquiry and special committees can be compared schematically as follows:

\footnotetext{
${ }_{525}$ Article 231 TFEU stipulates: "Save as otherwise provided in the Treaties, the European Parliament shall act by a majority of the votes cast. The Rules of Procedure shall determine the quorum".

${ }^{526} \mathrm{Cf}$. Section 2.4.4 on the powers of committees of inquiry.

${ }^{527} \mathrm{Cf}$. Section 2.4.3.1 for more information on the sub judice rule in relation to the right of inquiry.
} 


\begin{tabular}{|c|c|c|}
\hline & Committees of inquiry & Special committees \\
\hline $\begin{array}{l}\text { Relevant legal } \\
\text { arrangements }\end{array}$ & $\begin{array}{l}\text { Article } 226 \text { TFEU, } \\
\text { Interinstitutional } \\
\text { Agreement }{ }^{528} \text {, and Rule } 185 \\
\text { Rules of Procedure }\end{array}$ & $\begin{array}{lll}\text { Rule } 184 & \text { Rules } & \text { of } \\
\text { Procedure } & & \end{array}$ \\
\hline $\begin{array}{l}\text { Quorum needed } \\
\text { to establish the } \\
\text { committee }\end{array}$ & $\begin{array}{l}\text { Simple majority vote (at the } \\
\text { request of at least a quarter of } \\
\text { the MEPs) }\end{array}$ & Simple majority vote \\
\hline $\begin{array}{l}\text { Maximum } \\
\text { duration of its } \\
\text { existence }\end{array}$ & $\begin{array}{l}\text { Twelve months (the term can } \\
\text { be extended twice by three } \\
\text { months by means of a reasoned } \\
\text { decision) }\end{array}$ & $\begin{array}{l}\text { Twelve months (term } \\
\text { can be extended } \\
\text { continuously) }\end{array}$ \\
\hline $\begin{array}{l}\text { Scope of the } \\
\text { investigation }\end{array}$ & $\begin{array}{l}\text { Committees of inquiry may } \\
\text { only investigate alleged } \\
\text { contraventions or } \\
\text { maladministration in the } \\
\text { implementation of EU law } \\
\text { which are concrete and clearly } \\
\text { defined, which have occurred } \\
\text { in the past, and which are not } \\
\text { subjudice }\end{array}$ & $\begin{array}{l}\text { No explicit limitations. } \\
\text { Restraint should however } \\
\text { be exercised for issues } \\
\text { which are subjudice }\end{array}$ \\
\hline $\begin{array}{l}\text { Investigative } \\
\text { powers }\end{array}$ & $\begin{array}{l}\text { The powers of inquiry } \\
\text { committees exceed the general } \\
\text { powers of the European } \\
\text { Parliament and its Members. } \\
\text { These additional powers (right } \\
\text { to invite witnesses, access to } \\
\text { documents et cetera) are laid } \\
\text { down in the } 1995 \\
\text { Interinstitutional Agreement } \\
\text { and can only be used in the } \\
\text { course of an inquiry }\end{array}$ & $\begin{array}{l}\text { The powers of special } \\
\text { committees do not } \\
\text { exceed the general } \\
\text { powers of the European } \\
\text { Parliament and its } \\
\text { Members. }\end{array}$ \\
\hline
\end{tabular}

Figure 3.2 Committees of inquiry and special committees

Please note that the term 'special committee' is invented by Parliament itself. The Parliament replaced the more neutral term 'temporary committee' with the current term 'special committee' after a proposal to that effect by the parliamentary Working Party on Parliamentary Reform. In 2009, the Working Party suggested replacing 'temporary committee' by 'select' or 'special' committee, in order to demonstrate the special nature of these committees,

\footnotetext{
${ }_{528}$ Decision of the European Parliament, the Council and the Commission of 6 March 1995 on the detailed provisions governing the exercise of the European Parliament's right of inquiry (OJ L 1 13, 19.5.1995, pp. 2-4).
} 
while preserving the limited lifespan of such committees by including this aspect in the relevant mandate. ${ }^{529}$

\subsection{Proceedings of special committees}

Section 2.4.1 examines the chronological proceedings regarding investigations by committees of inquiry. Section 3.4.1 does the same for investigations by special committees. Section 3.4.2 discusses single aspects of investigations by these committees in more detail.

\subsubsection{Chronological proceedings}

Rule 184 EP Rules of Procedure stipulates: 'On a proposal from the Conference of Presidents, Parliament may at any time set up special committees [...]'. The Conference of Presidents may thus make a proposal to the Parliament to establish a special committee. The Conference of Presidents is free to determine the subject of the proposal, which may subsequently be amended by the plenary. This contrasts with a proposal to set up a committee of inquiry. The initial impetus for the establishment of a committee of inquiry is given by a request of at least a quarter of the members of the European Parliament. If such a request is made, the Conference of Presidents - and at a later stage the plenary - may not change the subject of the inquiry as proposed initially by the requesting MEPs. The subject of the inquiry can thus either be approved or rejected; it cannot be amended. It goes without saying, however, that this is a somewhat formalistic view. The Conference of Presidents and the plenary de facto do have the ability to change the subject by replying to the requestors: "we only agree with the establishment of a committee of inquiry if you file a new request and change the subject”.

Rule 184 EP Rules of Procedure further stipulates that for special committees the ' $[\ldots]$ powers, composition and term of office shall be defined at the same time as the decision to set them up is taken'. The second sentence of this Rule clarifies that neither the plenum, nor the special committee itself, can subsequently decide to alter this.

Like all committees of the European Parliament, the composition of special committees shall, as far as possible, reflect the composition of Parliament. ${ }^{530}$ Upon a proposal of the Conference of Presidents, the plenum determines the number of members and the composition of a committee of inquiry. ${ }^{531}$ The (vice-) chairperson(s) and rapporteur(s) are elected by the special committee itself at its constituent meeting. ${ }^{532}$ The term of office of special committees may not exceed twelve months. However, the Parliament may extend the term of office upon its expiry. ${ }^{533}$ The decision to set up a special committee is published in the Official Journal of the European Union.

529 European Parliament (2009). Working party on parliamentary reform. Third Interim Report on Committees and Delegations (PE 417.163/CPG/GT/Ann, 26.3.2009), p. 24.

530 Rule 186 (1) Rules of Procedure of the European Parliament.

531 Cf. Rule 186 (1) Rules of Procedure of the European Parliament.

532 In practice, these positions are shared out by agreement among Political Groups on the basis of the number of members within each Group; Cf. Corbett/Jacobs/Shackleton (2011), p. 147 .

${ }_{533}$ Rule 184 Rules of Procedure of the European Parliament. 
When the abovementioned formalities have been accomplished, the investigation can begin. As a general rule, special committees start by collecting information on the matter under investigation. Section 3.6 shows that special committees collect their information in the course of their investigations in a similar way to inquiry committees: they collect oral information through hearings, file requests for written information and conduct on-the-spot fact-finding investigations.

The division of labour among the members of the inquiry committee is similar to that of other committees of the European Parliament. The chairperson leads the committee of inquiry. He or she represents the committee both within the Parliament (in the Conference of Committee Chairs) and outside the Parliament. He or she can further have a powerful role in shaping the agenda of the committee and he or she presides over the committee meetings. ${ }^{534}$ The rapporteur is responsible for the committee's draft report, which can be amended in committee. ${ }^{535}$ Members of a special committee can attach a minority opinion to the report. Finally, the committee rapporteur presents the committee report to the Parliament prior to a plenary debate, which is generally held at the part-session following the submission of the report.

\subsubsection{Individual aspects of the investigations}

The following sections discuss individual aspects of the twelve special committees established since 1993.

\subsubsection{Duration of investigations}

There appears to be no single standard for the duration of special committee investigations. Some committees had a relatively short life of six months (BSE follow-up committee and Improving Safety at Sea committee), whereas other committees needed a year or longer to submit a report to the Parliament. With nineteen months of work, the Climate Change committee and the Financial, Economic and Social Crisis committee had the longest lives.

\subsubsection{Committee meetings}

Special committees generally meet in Brussels during the 'committee-weeks', which immediately follow the plenary session in Strasbourg and which precede the 'political groups week'. Some committees meet once a month, some of them twice. At the first meeting of a special committee (the 'constituent meeting'), the committee elects its bureau (the chair and the vice-chairs) and its rapporteur. ${ }^{536}$ The subsequent meetings are generally used for learning about the matter under investigation. To this end, committees usually organize hearings with (external) experts, but sometimes also conduct fact-finding visits outside the Parliament or discuss the matter of investigation internally. ${ }^{537}$

The busiest time is generally at the end of the investigation, when committees discuss their draft texts and amendments to these texts. The number of

\footnotetext{
${ }^{534}$ Corbett/Jacobs/Shackleton (2011), p. 147.

${ }_{535}$ Ibid. p. 158.

${ }^{536}$ Cf. Rule 191 (1) Rules of Procedure of the European Parliament.

${ }^{537} \mathrm{Cf}$. Section 3.7 on the gathering of information by special committees.
} 
amendments proposed to a draft text can be large. The special committees on Foot and Mouth disease, Human Genetics, and CIA-flights had to deal with some 270, 600 and 700 amendments respectively. In the case of Human Genetics, the plenary session still had to deal with 250 further amendments.

\subsubsection{Bureau, rapporteur, coordinators, and shadow rapporteurs}

Special committees generally consist of a bureau, a rapporteur, and several committee coordinators and shadow rapporteurs. As discussed above, the bureau (the chair and vice-chairs) and the rapporteur are elected by the committee at the constituent meeting. The bureau consists of a chair and several vice-chairs. Every political group may further designate one of their members as coordinator. The committee may delegate the power to take certain decisions to the coordinators, with the exception of decisions concerning the adoption of reports, opinions or amendments. ${ }^{538}$ Moreover, political groups designate shadow rapporteurs, whose task it is to follow the progress of the committee report and to find compromises within the committee on behalf of the political group. ${ }^{539}$

\subsubsection{The role of the rapporteur}

The rapporteur plays an important role in the course of an investigation. It is his or her task to submit a draft report to the committee. Practice shows that the rapporteur is often the driving force behind a special committee. At the outset of an investigation, the rapporteur generally presents a proposal to the committee on its working methods. He or she proposes when meetings will be held, what will be done, and how it will be done. In the course of the Echelon investigation, for example, the working programme proposed by the rapporteur was adopted by the committee. The working programme listed nine topics to be investigated consecutively at the individual meetings. By way of preparation for the meetings, the rapporteur systematically scrutinized and evaluated the material available. ${ }^{540}$

Although the bureau and the shadow rapporteurs must be consulted on important issues, there is inevitably some discretion on the part of the rapporteur to influence the emphasis (and the outcome) of an investigation. The initial appraisal by the rapporteur of material, for example, depends on his or her personal assessment. The ability to influence the investigation (be it consciously or not) further follows from the fact that rapporteurs tend to be better informed on the matters under investigation than other committee members. However, it goes without saying that the rapporteur cannot allow himself/herself too much freedom, as the final report of the committee ultimately needs majority support, both in committee and subsequently in plenary. The rapporteur should thus take into account the views within the committee. The Human Genetics investigation has shown that approval of a

\footnotetext{
538 Cf. Rule 192 Rules of Procedure of the European Parliament.

539 Cf. Rule 192 (3) Rules of Procedure of the European Parliament.

540 European Parliament (2001). Echelon committee. Report on the existence of a global system for the interception of private and commercial communications (ECHELON interception system) (Part 1, A5-0264/2001, 11.7.2001), p. 23.
} 
final text in committee in no sense guarantees that the text will also gain majority support in plenary. ${ }^{541}$ The rapporteur should thus, if possible, also take into account the views outside the special committee. A sense of diplomacy is thus an indispensable quality for any rapporteur in order to produce a report which is supported by a large majority both in committee and in plenary.

\subsubsection{Committee staff}

Special committees are assisted by a staff. In contrast to the US Congress, but not to the national parliaments of the Member States, the staffs assigned to committees of the European Parliament are relatively small. Committees of the European Parliament normally have four to ten administrators, one or two committee assistants who look after the logistics of the meetings, and a number of secretaries. ${ }^{542}$ The committee staff assists rapporteurs with background research and has an important role in briefing members on the past activities and positions adopted within the committee. ${ }^{543}$ In addition, other officials attend committee meetings. The Legal Service of the Parliament advises committees on legal questions, the Directorate-General for Information is represented and researchers from the Policy departments working alongside the committee secretariats also follow the meetings. Committee members are further assisted by staff members from their political group and by their personal assistants.

\subsubsection{Minority opinions}

Members of special committees can attach a minority opinion to the committee's final report. This right is exercised less often for special committees than inquiry committees, where it is common practice to include minority opinions in the final reports. Only the final reports of the special committees into Echelon and Policy Challenges and Budgetary Means of the Enlarged Union included minority opinions.

\subsection{Practice of special committees since 1993}

This section discusses the various investigations carried out by special committees since 1993. Section 1.4.3 highlights the differences between accountability investigations and non-accountability investigations. Only the former is relevant for this book as only accountability investigations serve as a means of holding executive actors to account. Therefore, this section starts by examining the twelve special committees in order to find out what kind of investigations they conducted. Section 3.6 subsequently analyzes the accountability investigations conducted by special committees since 1993 in more detail.

\footnotetext{
${ }^{541}$ The final report of the Human Genetics Committee was rejected in plenary. $C f$. Section 3.5.4.

${ }_{542}$ Corbett/Jacobs/Shackleton (2011), p. 151.

${ }^{543}$ Cf. Ibid.pp. 151-152.
} 


\subsubsection{Employment (1994-1995)}

In July 1994, the European Parliament decided to establish a temporary committee on employment. This temporary committee was set up to examine all aspects of employment policy in order to develop a coherent strategy for combating unemployment and creating sustainable employment. In this context, its task was to monitor the implementation of the Commission White Paper on 'Growth, Competitiveness and Employment', which was approved by the European Council on 11 December 1993 and which recommended increased cooperation in research and development, the adoption of a new development model taking into account the environment and qualitative needs, and action to be taken concerning the employment market. ${ }^{544}$ Furthermore, the committee was set up with a view to formulating initial recommendations on behalf of the European Parliament for the European Council meeting of December 1994. The committee on Employment adopted its final report in June 1995. The committee found that the EU and the Member States should adopt an integrated employment strategy. ${ }^{545}$ The committee also made a series of recommendations concerning boosting investment, working time and working patterns, the promotion of new employment areas, support for small firms, the need to reduce non-wage labour costs, taxation, and specific measures for the most vulnerable in the labour market, such as the young, the unskilled, women and disabled people. ${ }^{546}$ The plenum adopted the committee's final report in July 1995.

The main task of this committee was to examine all aspects of employment policy in order to develop a coherent strategy for combating unemployment and creating sustainable employment and to formulate initial recommendations on behalf of the European Parliament. Hence, it cannot be said that this committee was set up with the principal aim of holding executive actors to account. It should thus be qualified as a non-accountability investigation.

\subsubsection{BSE follow-up (1997)}

The BSE follow-up committee was established in April 1997. This special committee succeeded the temporary committee of inquiry into BSE which had been set up in August 1996 to investigate the handling of the BSE crisis. ${ }^{547}$ This committee of inquiry had revealed mismanagement by the Commission, the Council and the UK government. On the basis of its findings, the inquiry committee formulated over 70 recommendations for the future, the majority of which were addressed to the Commission. In order to emphasize the seriousness of the matter, the Parliament threatened to table a motion of censure against the Commission if the recommendations were not carried out before a reasonable deadline, or by November 1997 at the latest. ${ }^{548}$ The BSE

\footnotetext{
544 Cf. European Commission (1993). Growth, competitiveness, and employment. The challenges and ways forward into the 21 st century (COM /93/700, 05.12.1993).

545 European Parliament (1995). Temporary committee on Employment. Report on a coherent employment strategy for the European Union (A4-0166/95, 28.6.1995), p. 6.

${ }^{546}$ Ibid. pp. 6-14.

${ }^{547}$ Section 2.5.2 examines the work of this temporary committee of inquiry.

${ }_{548}$ Resolution on the results of the Temporary Committee of Inquiry into BSE (OJ C 85, 17.3.1997, p. 61).
} 
follow-up committee was established to monitor the implementation of these recommendations by the Commission. The committee finished its final report in November 1997. It concluded that the Commission had made "a great deal of progress" in a relatively short time, and that the Commission had implemented most of the recommendations in full or in part in the six months following the inquiry into BSE. ${ }^{549}$ The BSE follow-up committee's report was adopted by the plenary in November 1997 and the threat to censure the Commission was withdrawn.

This is a clear example of an accountability investigation. The BSE follow-up committee was established to monitor the implementation by the Commission of the recommendations made by the committee of inquiry into BSE, which preceded the BSE follow-up committee. This type of scrutiny can be described as ongoing, and differs from ex post scrutiny. Ongoing scrutiny implies that the Parliament looks over the executive's shoulder while it operates, whereas $e x$ post scrutiny involves the retrospective assessment of past executive action. Section 2.4.3.1 shows that the right of inquiry can only be used to conduct $e x$ post accountability investigations, as 'alleged contraventions or maladministration in the implementation of Union law' must be on hand. Because the BSE follow-up investigation was an ongoing investigation, the Parliament could not set up a committee of inquiry on this issue. Furthermore, it was not possible to set up another committee of inquiry on the BSE issue, as Article 2 (5) IIA stipulates that re-establishment of a committee of inquiry for matters into which an inquiry has already been held is only allowed after at least twelve months have elapsed since that inquiry was closed and only after new facts have emerged.

\subsubsection{Echelon (2000-2001)}

The Echelon committee was established in response to allegations of the existence of a comprehensive global interception system called Echelon. ${ }^{550}$ The name Echelon was used to describe an intelligence collection and analysis network supposedly operated on behalf of the five signatory states to the socalled UKUSA Agreement (Australia, Canada, New Zealand, the United Kingdom and the United States). The special committee into Echelon was established in July 2000 to verify the existence of this communications interception system and to assess its compatibility with Community law. 551 The Echelon committee adopted its final report in July 2001 and concluded that the existence of a global interception system was no longer in doubt. It found that the system could be used to intercept both private and commercial communications, but that this system was, both technically and practically, not

\footnotetext{
549 European Parliament (1997). BSE follow-up committee. Report on the European Commission's follow-up of the recommendations made by the committee of inquiry into BSE (A4-0362/97, 14.11.1997), p. 50.

${ }_{550}$ European Parliament (2001). Echelon committee. Report on the existence of a global system for the interception of private and commercial communications (ECHELON interception system) (Part 1, A5-0264/2001, 11.7.2001), p. 21.

${ }^{551} \mathrm{Cf}$. Decision to set up the special committee into Echelon (OJ C 121, 24.4.2001, p. 131).
} 
able to intercept all communications. ${ }^{552}$ The committee further concluded that Member States using intelligence systems for purposes other than state security would constitute an infringement of Community law. The committee went on to say that such an intelligence system is at odds with the Member States' duty of loyal cooperation and with the concept of a common market based on free competition if such a system is misused by an EU Member State for the purpose of gathering competitive intelligence. Any interception by such an intelligence system moreover represents serious interference with an individual's right of privacy ex Article 8 of the European Convention on Human Rights. ${ }^{553}$ The Echelon committee's report was adopted by the plenary in September 2001.

The Echelon committee was established after public concern had arisen regarding the alleged existence and use of the Echelon system. Its aim was to find out whether Echelon actually existed and, if so, who was responsible for the existence of this secret system. Hence, the Echelon committee conducted an accountability investigation. The question then arises why the Parliament did not set up a committee of inquiry. Prior to the establishment of the committee, there was indeed debate within the Parliament on what kind of temporary committee should be set up. Some members, particularly MEPs of the European Greens, advocated setting up a committee of inquiry, whereas others, mainly German and British MEPs, preferred that a special committee be established. This resulted in two proposals which were voted upon on 5 July 2000. Only the proposal to set up a special committee gained majority support. In its final report, the Echelon committee explained why the Parliament rejected the proposal to establish a committee of inquiry:

"The European Parliament decided to set up a temporary committee because a committee of inquiry can be set up only to investigate violations of Community law under the EC Treaty (Article 193 TEC), and such committees can accordingly only consider matters governed by it. Matters falling under Titles V (Common Foreign and Security Policy) and VI (Police and Judicial Cooperation in Criminal Matters) of the Treaty on European Union are excluded. Moreover, under the interinstitutional decision, the special powers of a committee of inquiry to call people to appear and to inspect documents apply only if grounds of secrecy or public or national security do not dictate otherwise, which would certainly make it impossible to summon secret services to appear. Furthermore, a committee of inquiry cannot extend its work to third countries, because by definition the latter cannot violate EU law. Thus, setting up a committee of inquiry would only have restricted the scope of any investigations opening up any additional rights, for which reason the idea was rejected by a majority of Members of the European Parliament." ${ }_{554}$

\footnotetext{
552 European Parliament (2001). Echelon committee. Report on the existence of a global system for the interception of private and commercial communications (ECHELON interception system) (Part 1, A5-0264/2001, 11.7.2001), p. 133.

${ }_{553}^{5}$ Ibid. pp. 133-134.

${ }^{554}$ Ibid. pp. 22-23.
} 
This clearly shows how the restricted scope of the right of inquiry withheld the Parliament from establishing a committee of inquiry. Furthermore, Wiersma (a member of the Echelon committee) and Van de Water (an assistant to the PES group in the Parliament) pointed out that there was some fear in the Parliament that particular Member States would challenge the establishment of a committee of inquiry before the European Court of Justice. ${ }^{555}$ According to the legal department of the European Parliament, so Wiersma and Van de Water claim, such an action would have had a great chance of success. ${ }^{556}$ Member States could have indeed challenged the decision to establish a committee of inquiry through an action for annulment (at present laid down in Article 263 TFEU), by claiming that the right of inquiry was being used outside the scope laid down in the Treaty provision. ${ }^{557}$ The committee mandate clearly cut across the prescribed Community pillar, focussing on matters within the second and third pillars of the European Union. It should be noted that the Treaty of Lisbon has made it possible to set up committees of inquiry to look into cases of Union law, thus including the former second and third pillars.

\subsubsection{Human genetics (2001)}

In December 2000, the European Parliament established a temporary committee on human genetics (hereafter: Human Genetics committee). Human genetics was a topical issue due to the quick developments in the field of biotechnology, especially genetic engineering, and as a consequence of the British decision to allow research on embryonic stem cells under certain conditions. The Human Genetics committee was set up to address the ethical, social, legal, and economic issues surrounding human genetics and to gain a better insight into the delicate relation between the need to reconcile freedom of research with the principle of human dignity. ${ }^{558}$ To this end, the committee was commissioned to examine new and potential developments in human genetics, and to investigate the extent to which the public interest required a proactive response to such developments. ${ }^{559}$ The Human Genetics committee adopted its final report in November 2001. While urging support for research in genetics and related technologies, the committee recommended a harmonized European regulatory regime that would, for example, prohibit the use of genetic testing for any 'non-medical' purpose such as in connection with an application for insurance or employment. ${ }^{560}$ The committee also urged a system be set up for evaluating and licensing genetic tests and it expressed the view that a regulatory regime for such tests should incorporate ethical principles. ${ }^{561}$ Finally, the committee suggested that the use of somatic cell nuclear transfer ('therapeutic cloning') in stem cell research and the creation of

\footnotetext{
${ }_{555}$ Wiersma (2004), p. 226; Wiersma/Van de Water (2001), p. 12.

${ }_{556}$ Wiersma/Van de Water (2001), p. 12.

${ }_{557}$ Section 2.4.5.1 discussed the action for annulment regarding the establishment of committees of inquiry.

${ }_{558}$ European Parliament (2001). Human Genetics committee. Report on the ethical, legal, economic and social implications of human genetics (A5-0391/2001, 8.11.2001), p. 33.

559 Ibid. pp. 33-34.

560 Ibid. pp. 17-23.

${ }^{561}$ Ibid. pp. 18-24.
} 
human embryos specifically for research purposes should be banned. ${ }^{562}$ The final report was rejected by the plenum on 29 November $2001^{563}$, after ELDR and PES amendments in favour of 'therapeutic' cloning were approved. This was the first (and to date also the last) time that a final report from a temporary committee of the European Parliament was rejected by the plenum. Why did this occur? Committee Chairman Goebbels pointed out that the rapporteur, Fiori, produced a "mainstream" report avoiding extreme positions. He went on to say that "the subject raised such passions that in a session that lasted seven hours, the committee had to deal with some 600 amendments. This created many inconsistencies in the text. The plenary session still had to deal with 250 amendments, and the final text was so flawed that nobody could identify with it so the report was rejected by Parliament". ${ }^{564}$ Goebbels further pointed out that the division was not left-right. "It went through all political groups. It was more a divide between the 'optimists', enthusiastic about the promise of these new scientific developments, and the 'pessimists', fearful of the dangers. Different coalitions formed around different issues, so that in the end, nobody was satisfied". ${ }^{565}$

This investigation represents a classic example of a non-accountability investigation. The task of the special committee was to get informed and, possibly, prepare for decision-making in the field of human genetics. It thus assisted the Parliament in performing its legislative task, and was in no sense established to hold executive actors to account.

\subsubsection{Foot-and-mouth disease (2002)}

In 2001, outbreaks of foot-and-mouth disease (hereafter: FMD) occurred in the United Kingdom, the Netherlands, and, on a smaller scale, in France and Ireland. A policy of large-scale slaughtering was preferred over vaccination of the animals. Since vaccination would have resulted in a complete ban on the use of the produce from vaccinated animals in the food industry, the majority of British farmers were opposed to vaccination. Millions of animals were slaughtered, which raised public concern throughout Europe and which also had a significant impact on the economy of the countries concerned. ${ }^{566}$ Concerns within the Parliament about the FMD crisis led to the establishment of the FMD committee in January 2002. The task of this committee was to analyse the management of the foot-and-mouth epidemic and to suggest ways of preventing similar outbreaks in the future, in particular with regard to vaccination. The FMD committee adopted its final report in November 2002. The committee criticized the United Kingdom for inadequate handling of the FMD crisis. ${ }^{567}$ The committee was less critical of the handling of the crisis in Netherlands and France, whereas Ireland was praised for its effective and

\footnotetext{
562 Ibid. pp. 26-29.

56337 votes in favour, 316 against and 47 abstentions. Cf. OJ C 153, 27.6.2002, pp. 231-232.

564 Goebbels (2001).

565 Goebbels (2001).

566 European Parliament (2002). FMD committee. Report on measures to control Foot and Mouth Disease in the European Union in 2001 and future measures to prevent and control animal diseases in the European Union (A5-0405/2002, 28.11.2002), p. 33.

567 Ibid. pp. 10-13.
} 
efficient methods for combating FMD. ${ }^{568}$ The FMD committee observed that the Commission responded to the crisis immediately and took the necessary decisions. However, the Commission failed in its review of the Member States' contingency plans. ${ }^{569}$ The committee was of the opinion that the basic nonvaccination policy had assigned undue priority to trade policy aspects. ${ }^{570}$ In order to avoid similar mass slaughter in the future, the committee formulated a large number of recommendations, among which was the recommendation that vaccination be considered a first-choice option in the event of a future outbreak. ${ }^{571}$ The FMD committee's final report was approved by the plenum in December 2002.

This was an investigation of a hybrid nature. On the one hand, this special committee was mandated to find out whether there had been maladministration in the management of the foot-and-mouth disease. On the other hand, the committee's task was to evaluate existing legislation and to prepare new legislation. As there were no concrete allegations of 'contraventions or maladministration in the implementation of Community law', as required at that time in art. $193 \mathrm{EC}$ Treaty (currently in art. $226 \mathrm{TFEU}$ ) to establish a committee of inquiry ${ }^{572}$, setting up a special committee was the most obvious option.

\subsubsection{Improving safety at sea (2003-2004)}

On 19 November 2002 the oil tanker Prestige sank off the coast of Galicia, Spain. This caused an ecological and economic disaster which particularly hit the fishing industry and tourism in Galicia and neighbouring regions. The oil spread over a large area and caused pollution not only on the coast of Spain but also on those of France and Portugal. In November 2003 the Parliament established a temporary committee whose task it was to examine maritime disasters in detail, in particular the Prestige and the Erika (which sank in the Bay of Biscay in 1999) and to further analyze their social and economic consequences, and to assess maritime safety standards more generally and the application of these standards by the Member States in compliance with both EU law and international law. The committee was further commissioned to ensure the implementation of the recommendations contained in the EP resolution of 23 September 2003 and to propose additional measures. ${ }^{573}$ The committee on Improving Safety at Sea adopted its final report in April 2004. The committee criticized the Spanish authorities for decisions taken before, during and after the Prestige disaster ${ }^{574}$ and it formulated recommendations to prevent similar maritime disasters in the future.575 Among the recommendations, the committee called on Member States to set up a

\footnotetext{
${ }^{568}$ Ibid. pp. 13-15.

${ }_{569}$ Ibid. pp. 15-16.

570 Ibid. p. 9.

${ }^{571}$ Ibid. p. 18.

${ }^{572}$ Cf. Corbett/Jacobs/Shackleton (2011), p. 333.

573 European Parliament (2004). Committee on Improving Safety at Sea. Report on improving safety at sea (A5-0257/2004, 7.4.2004), p. 14.

${ }^{574}$ Ibid. p. 7.

${ }^{575}$ Ibid. pp. 7-13.
} 
European coastguard service. ${ }^{576}$ Further recommendations included a call for more powers for the European Agency for Maritime Safety, improved working conditions and safety for seafarers and better protection of the Baltic waters, given that many Russian oil tankers do not meet EU safety standards. ${ }^{577}$ The temporary committee's final report was approved by the plenum on 21 March 2004.

Like the investigation into the foot-and-mouth disease, the investigation on improving safety at sea was an investigation of a hybrid nature. On the one hand, the special committee's task was to examine past maritime disasters in detail and it was commissioned to evaluate the extent to which earlier recommendations had already been translated into policy. On the other hand, the committee was commissioned to assess maritime safety standards more generally and to formulate recommendations for the future. In view of the absence of concrete allegations of 'contraventions or maladministration in the implementation of Community law', as required to establish a committee of inquiry, setting up a committee of inquiry would have been inadmissible. A special committee was furthermore preferred over a committee of inquiry because many maritime safety regulations fall under the authority of the International Maritime Organization (IMO), and which consequently lie beyond the EU sphere. ${ }^{578}$ This was problematic because the scope of the right of inquiry was limited to alleged abuses in the Community sphere (at present: Union sphere).

Selecting a special committee was also a tactical choice. Spanish MEPs of the EPP-ED group were not favourably disposed to an investigation of any kind into the Prestige disaster because of a fear that the centre-right Spanish government would then inevitably come under close scrutiny. Left-wing Spanish MEPs, on the other hand, advocated the establishment of a committee of inquiry. The middle course was adopted by setting up a special committee. Both Spanish camps had their eyes on the committee rapporteur role so they could steer the final report in their respective directions. Also here, the Parliament adopted a middle course by appointing an MEP who was neither Spanish, nor a Member of the centre-right EPP-ED or the centre-left PES, namely the Belgian Liberal Dirk Sterckx (ELDR). ${ }^{579}$

\subsubsection{Policy challenges and budgetary means of the enlarged Union 2007-2013 (2003-2004)}

The Parliament decided to set up a special committee on the Policy Challenges and Budgetary Means of the Enlarged Union 2007-2013 (hereafter: PCBM committee) in September 2004. In doing so, the Parliament followed the previous practice of establishing temporary committees for the consideration of financial perspectives (Delors I and Delors II-packages).580 A 'financial

\footnotetext{
576 Ibid. p. 8.

577 Ibid. p. 10.

578 Wiersma (2004), p. 226.

579 Interview with Dirk Sterckx, 30 June 2011.

580 In 1987 the Parliament established a temporary committee to prepare the first "Delors package". The committee was chaired by Lord Plumb, the EP President at that time, and it had two rapporteurs: Enrique Barón (PES) and Karl von Wogau (EPP). In 1992 the
} 
perspective' is a multiannual financial framework which serves as a reference for the annual budget of the European Union. Before Lisbon, financial perspectives were foreseen by neither primary nor secondary Community law. ${ }^{581}$ Financial perspectives used to be laid down in an interinstitutional agreement between the Commission, the Council and the European Parliament. Before the special committee was established, the Commission had adopted both its proposal for a new financial perspective, the so-called 'Prodi package', and two sets of legislative proposals in order to ensure the continuity of Community legislation. ${ }^{582}$ The PCBM committee was established to determine a common stance before negotiating these proposals with the Commission and the Council. In particular, the Parliament mandated the PCBM committee to define the Parliament's political priorities for the future financial perspective both in legislative and budgetary terms and, in so doing, to ensure coherence between the Parliament's political priorities and its position on the next financial perspective. ${ }^{583}$ The plenary adopted the final report of the PCBM committee in June 2005.

This investigation offers a typical example of a non-accountability investigation. Its aim was to define the Parliament's political priorities for the future financial perspective both in legislative and budgetary terms. The investigation was by no means aimed at holding executive actors to account.

\subsubsection{CIA flights (2006-2007)}

Allegations regarding the existence of secret CIA detention centres in Europe, illegal abductions, and ill-treatment of prisoners led to the establishment of the CIA flights committee in January 2006. Its primary task was to verify the truthfulness of these allegations. The CIA flights committee was further mandated to verify the legality of the alleged violations, and to verify whether Member States, public officials, persons acting in an official capacity or European Union institutions had been involved. The committee was mandated to submit recommendations concerning "the political, legal and administrative conclusions to be drawn at the European level as well as possible consequences for EU relations with third countries". ${ }^{584}$ The CIA flights committee adopted its report in January 2007. The committee concluded that European countries had been "turning a blind eye" to flights operated by the CIA which, "on some occasions, were being used for extraordinary rendition or the illegal

\footnotetext{
Parliament established a temporary committee to prepare the second "Delors package". This committee was chaired by Emilio Colombo (EPP). Thomas Von Der Vring (PES) was appointed as rapporteur. $C f$. Corbett/Jacobs/Shackleton (2011), p. 167.

581 At present, the financial perspective (or 'multiannual financial framework') is provided for in Article 312 TFEU.

582 European Parliament (2004). PCBM committee. Working document (no. 1) on the organisation and working methods (PE 349.837, 21 October 2004), p. 2.

583 European Parliament (2004). PCBM committee. Working document (no. 2) on the financial perspective 2007-2013: state of play (PE 349.838, 21 October 2004), p. 2.

${ }_{584}$ European Parliament decision setting up a temporary committee on the alleged use of European countries by the CIA for the transportation and illegal detention of prisoners (OJ C 287 E, 24.11.2006, p. 159).
} 
transportation of detainees". ${ }^{585}$ The committee stated that in some cases "temporary secret detention facilities in European countries may have been located at US military bases" and that "there may have been a lack of control" over such bases by European host countries. ${ }^{586} 21$ cases of extraordinary rendition were mentioned where rendition victims were transferred through a European country. The committee deplored these renditions "as an illegal instrument used by the USA in the fight against terrorism" and it condemned the "acceptance and concealing of the practice, on several occasions, by the secret services and governmental authorities of certain European countries". ${ }^{587}$ Concerning the use of torture, the committee noted that the majority of cases involved incommunicado detention and torture during interrogations, as was confirmed by the victims and/or their lawyers testifying before the committee. ${ }^{588}$ The plenary adopted the final report in February 2007.

The investigation was in essence an accountability investigation. The CIA flights committee was established to investigate the alleged use of European countries by the CIA for the transportation and illegal detention of prisoners. Why did the European Parliament not use its right of inquiry to investigate this matter? The answer is similar to that for the Echelon investigation. The CIA flights issue was not a first pillar issue and thus did not fall within the scope of the 'pre-Lisbon' right of inquiry. Secondly, in view of the fact that the CIA flights issue also concerned a matter of 'secrecy or public or national security', it was equally questionable whether it would have been useful to establish a committee of inquiry to investigate the matter, as inquiry powers apply only if grounds of secrecy or public or national security do not dictate otherwise.

\subsubsection{Climate change (2007-2008)}

The Parliament established a temporary committee on climate change in April 2007. The committee was set up with the aim of making the challenges presented by climate change a priority on the European and international agenda. ${ }^{589}$ Its task was to analyze and evaluate the state of climate change and the application of relevant Community legislation, to formulate proposals on the EU's future policy on climate change, and to coordinate the Parliament's position in that respect. ${ }^{590}$ The Climate Change committee adopted its final report in December 2008. The committee showed concern that "climate change is both more rapid and more serious in terms of its adverse effects than was

\footnotetext{
585 European Parliament (2007). CIA Flights committee. Report on the alleged use of European countries by the CIA for the transportation and illegal detention of prisoners (A60020/2007, 30.1.2007), p. 11.

${ }_{586}$ Ibid.p. 24.

${ }_{587}$ Ibid.p. 11.

588 Ibid. p. 11.

589 European Parliament (2008). Climate Change Committee. Report on "2050: The future begins today - Recommendations for the EU's future integrated policy on climate change" (A6-0495/2008, 10.12.2008), p. 45.

${ }_{590}$ European Parliament decision of 25 April 2007 on setting up a temporary committee on climate change (OJ C 74 E, 20.3.2008).
} 
previously thought". ${ }^{591}$ It stressed that it was important "not to capitulate in face of the complexity of the problem but to show a visionary desire to make a difference" ${ }^{592}$ In line with this, the committee formulated a large number of recommendations. ${ }^{593}$ The plenary adopted the final report in February 2009.

The investigation was a typical non-accountability investigation. Its main aim was to formulate proposals on the EU's future policy on climate change and to coordinate the position of the European Parliament in that respect.

\subsubsection{Financial, economic, and social crisis (2009-2010)}

The Parliament established a special committee on the financial, economic and social crisis in October 2009. The committee was set up to analyze and evaluate the extent and the impact of the financial, economic and social crisis, and to analyze and evaluate the current implementation of EU legislation in the relevant areas "with a view to combating unemployment and responding to demographic and climate challenges, while complying with the subsidiarity principle". ${ }^{594}$ The special committee's report of was adopted in plenary in July 2011.595

Even just the title of the final report indicates that this special committee conducted a non-accountability investigation: 'Report on the financial, economic and social crisis: recommendations concerning the measures and initiatives to be taken'. The special committee analyzed the causes and the consequences of the financial, economic and social crisis. The main aim of this analysis was to formulate recommendations for the future; not to call those responsible for the crisis to account.

\subsubsection{Policy Challenges and Budgetary Resources for a Sustainable European Union after 2013 (2010-2011)}

In July 2010 the Parliament established a special committee on Policy Challenges and Budgetary Resources for a Sustainable European Union after 2013. The committee succeeded the special committee on the Policy Challenges and Budgetary Means of the Enlarged Union 2007-2013 discussed in Section 3.5.7. The Policy Challenges committee's mandate was to define the European Parliament's political priorities for the new post-2013 multiannual financial framework, both in legislative and budgetary terms and to submit guidelines

\footnotetext{
591 European Parliament (2008). Climate Change Committee. Report on "2050: The future begins today - Recommendations for the EU's future integrated policy on climate change" (A6-0495/2008, 10.12.2008), p. 17.

592 Ibid. pp. 39-40.

${ }_{593} \mathrm{Ibid}$. pp. 16-40.

${ }^{594}$ European Parliament decision of 7 October 2009 on setting up a special committee on the financial, economic and social crisis, and its powers, numerical composition and term of office (OJ C 230 E, 26.8.2010, p. 11).

595 European Parliament (2011). Committee on the financial, economic and social crisis. Report on the financial, economic and social crisis: recommendations concerning the measures and initiatives to be taken (A7-0228/2011, 14.6.2011).
} 
for the resources necessary for the Union to implement these priorities. ${ }^{596}$ The special committee's report was adopted in plenary in June 2011.

This investigation was a non-accountability investigation. Its aim was to define the Parliament's political priorities for the future financial perspective both in legislative and budgetary terms.

\subsubsection{Organized crime, corruption and money laundering}

The Parliament established a temporary committee on organized crime, corruption and money laundering in April 2012. The committee was set up with the aim of evaluating the extent of organized crime's impact on the EU economy and society and recommend legislative and other measures to enable the EU to respond to these threats at international, European and national levels. As this committee is still active at the time of writing, it is not possible to report on the outcomes of this investigation. This investigation will therefore not be discussed further in this book. The committee's mandate, however, points to a non-accountability investigation.

\subsubsection{Types of investigation: concluding remarks}

The above shows that the Parliament uses its special committees both to conduct 'non-accountability investigations' and 'accountability investigations'. It should be recalled that the distinction between the two types of investigation is fairly theoretical and that it is not always possible to make a clear distinction between the two types of investigation in practice. Parliamentary investigations will generally have features of both types of investigations. Nonaccountability investigations could very well be used to call the executive to account and accountability investigations will generally trigger new legislative proposals. The terms do, however, represent the extremes of a spectrum on which all parliamentary investigations can be placed. Single investigations will, as a rule, not match one of the extremes. They will rather be either mainly accountability-type or mainly legislative-type. The investigations into Employment, Human Genetics, Policy Challenges and Budgetary Means of the Enlarged Union 2007-2013, Climate Change, Financial, Economic and Social Crisis, and Policy Challenges and Budgetary Resources for a Sustainable European Union after 2013 were - to differing degrees - in essence nonaccountability investigations. By contrast, the remaining investigations (BSE follow-up, Echelon, Foot and Mouth Disease, Improving Safety at Sea, and CIA flights) were in essence accountability investigations. The latter category is particularly relevant for this book, since these investigations were aimed at holding executive actors to account. Section 3.6 examines these five investigations in further detail.

The question arises whether the Parliament has set up special committees in cases where it could have established a committee of inquiry. If so, that might

\footnotetext{
${ }^{596}$ European Parliament (2011). Committee on Policy Challenges and Budgetary Resources for a Sustainable European Union after 2013. Report on Investing in the future: a new Multiannual Financial Framework (MFF) for a competitive, sustainable and inclusive Europe (A7-0193/2011, 26.5.2011), p. 4.
} 
indicate a preference on the part of the Parliament for the former type of committee.

It is not surprising that special committees were set up to carry out the "nonaccountability investigations' given the fact that the right of inquiry is designed as an instrument to conduct 'accountability investigations'. Establishing a committee of inquiry was simply inadmissible given the fact that there were no 'alleged contraventions or maladministration in the implementation of Union law', as required by Article 226 TFEU. Due to this restriction on the use of the right of inquiry, the Parliament was furthermore unable to establish committees of inquiry for the 'accountability investigations' into Employment, BSE follow-up, Foot and Mouth Disease, and Improving Safety at Sea.

The investigations into Echelon and CIA flights prima facie seem to be cases in which the Parliament could also have established a committee of inquiry (instead of a special committee). In both cases there were alleged contraventions of EU law for which the Parliament wanted to call executive actors to account. Why did the Parliament not set up committees of inquiry in these cases? The main reason is that both investigations concerned second and third-pillar issues ${ }^{597}$, which at that time - before the Treaty of Lisbon - fell outside the scope of the right of inquiry. These investigations would, in this respect, have been admissible under the current provision on the right of inquiry (Article 226 TFEU), which authorizes the Parliament to set up inquiry committees to look into cases of Union law, thus including the former second and third pillar. There were, however, further reasons why the Parliament did not set up a committee of inquiry in both cases. The powers of committees of inquiry, as laid down in the Interinstitutional Agreement on the right of inquiry apply only if grounds of secrecy or public or national security do not dictate otherwise. Therefore it was open to doubt whether setting up a committee of inquiry on these particular issues would have made sense. Finally, the Echelon committee observed that a committee of inquiry cannot extend its work to third countries, because by definition the latter cannot violate EU law (as required by Article 226 TFEU). The Echelon committee concluded: "setting up a committee of inquiry would only have restricted the scope of any investigations opening up any additional rights, for which reason the idea was rejected by a majority of Members of the European Parliament”. ${ }^{598}$

No evidence has been found indicating a general preference for setting up special committees over setting up committees of inquiry. It seems it is not an unwillingness to set up committees of inquiry, but rather the narrow scope of the right of inquiry which accounts for the more frequent use of special committees. In particular, the fact that the establishment of a committee of

\footnotetext{
597 The second pillar was the Common Foreign and Security Policy (CFSP) pillar, which contained foreign policy and military matters. The third pillar was Police and Judicial Cooperation in Criminal Matters (PJCC), which brought together cooperation in the fight against crime. This pillar was originally named Justice and Home Affairs (JHA). The first pillar was the European Communities pillar.

${ }_{598}$ European Parliament (2001). Echelon committee. Report on the existence of a global system for the interception of private and commercial communications (ECHELON interception system) (Part 1, A5-0264/2001, 11.7.2001), pp. 22-23.
} 
inquiry requires the existence of 'alleged contraventions or maladministration in the implementation of Union law' has proven an obstacle for the use of the right of inquiry.

That the Parliament does not have a general preference for its special committees is also indicated by the fact that the Parliament set up a committee of inquiry, and not a special committee, in response to the crisis of the Equitable Life Assurance Society in 2006.599 The two inquiries in the mid-90s (into Transit and $\mathrm{BSE}^{600}$ ), were followed by a decade (1997-2006) during which the Parliament did not make use of its right of inquiry. During this same period, the Parliament set up six special committees (BSE follow-up, Echelon, Human Genetics, Foot and Mouth Disease, Improving Safety at Sea, and Policy Challenges and budgetary means of the enlarged Union 2007-2013). The restricted scope of the right of inquiry meant that the Parliament could not set up a committee of inquiry in any of these six cases. The Equitable Life case did fall within the scope of the right of inquiry, and the Parliament was thus faced with the choice between creating a temporary committee of inquiry and a temporary special committee. The Parliament probably would have set up a special committee had it had a preference for this type of committee but it chose to establish a committee of inquiry.

Finally, reference can be made to one of the recommendations formulated by the special committee into the CIA flights, which read: "the powers of Parliament's temporary inquiry committees should be reinforced and the interinstitutional decision governing the exercise of Parliament's right of inquiry be amended accordingly". ${ }^{601}$ Although the committee did not elaborate on how the Interinstitutional Agreement should be amended, this recommendation does indicate that the Parliament is of the opinion that matters such as the CIAflights should be investigated by committees of inquiry, not by special committees.

\subsection{Accountability investigations by special committees}

This section chronologically analyzes the accountability investigations conducted by special committees since 1993 to the present day: BSE follow-up (Section 3.6.1), Echelon (Section 3.6.2), Foot and mouth disease (Section 3.6.3), Improving Safety at Sea (Section 3.6.4), and CIA flights (Section 3.6.5).

\subsubsection{BSE follow-up}

\subsubsection{Subject, establishment and duration of the investigation}

At the plenary session of 23 April 1997, the Parliament set up the BSE followup committee. In response to the commotion caused by the BSE crisis in the mid-90s, the European Parliament established a committee of inquiry whose task it was to identify any malfunctioning in the handling of the BSE problem

\footnotetext{
${ }^{599} \mathrm{Cf}$. Section 2.5.3.

${ }^{600} \mathrm{Cf}$. Sections 2.5.1 and 2.5.2.

601 European Parliament (2007). CIA Flights committee. Report on the alleged use of European countries by the CIA for the transportation and illegal detention of prisoners (A60020/2007, 30.1.2007), p. 30.
} 
and to formulate conclusions pertaining to public health requirements. ${ }^{602}$ The committee of inquiry found shortcomings on the part of the United Kingdom, the Council and the Commission for the handling of the BSE problem. On the basis of the inquiry committee's final report, the Parliament adopted a resolution calling on the Commission to take urgent and effective action to follow up on the recommendations in the report. ${ }^{603}$ The Parliament threatened to table a motion of censure against the Commission if the recommendations were not been carried out within a reasonable deadline, or by November 1997 at the latest. ${ }^{604}$ After the committee of inquiry ceased to exist, the European Parliament set up a new temporary committee; a special committee. The committee's task was to monitor the action taken by the Commission on the recommendations made by the temporary committee of inquiry into BSE. 605

The BSE follow-up committee was composed of 20 full members and 20 substitutes. The committee started its work in April 1997 under the chairmanship of the German MEP Dagmar Roth-Behrendt (PES) and another German MEP, Reimer Böge (EPP-ED), who previously chaired the committee of inquiry into BSE, as rapporteur. The BSE follow-up committee submitted its report to Parliament in November $1997 .{ }^{606}$

\subsubsection{Committee proceedings}

The BSE follow-up committee held its constituent meeting on 24 April 1997 and adopted its final report six-and-a-half months later on 7 November 1997. Twelve meetings were held at the rate of two per month. Unlike the inquiries discussed in Chapter 2 and the other accountability investigations carried out by special committees which are examined in the course of this chapter, the BSE follow-up investigation was an exercise of ongoing scrutiny. Ongoing scrutiny implies that the Parliament looks over the executive's shoulder while it operates, whereas ex post scrutiny involves retrospective assessment (hence 'after the fact' ${ }^{\prime 07}$ ) of how the executive has operated. In the course of its investigation, the BSE follow-up committee monitored how the Commission implemented the recommendations made by the committee of inquiry into BSE.

\section{Gathering of information}

The BSE follow-up committee organized its work by means of monthly progress reports. The Commission provided the special committee with an overview of the measures that it had taken regarding BSE on a monthly

\footnotetext{
${ }^{602}$ Section 2.5.2 discusses the inquiry into the handling of the BSE crisis.

${ }^{603}$ Resolution on the results of the Temporary Committee of Inquiry into BSE (OJ C 85, 17.3.1997, p. 61).

${ }^{604}$ Resolution on the results of the Temporary Committee of Inquiry into BSE (OJ C 85, 17.3.1997, p. 61).

${ }^{605} \mathrm{Cf}$. Decision on the setting up of a temporary committee instructed to monitor the action taken on the recommendations made concerning BSE (OJ C 150, 19.5.1997, p. 9).

606 European Parliament (1997). BSE follow-up committee. Report on the European Commission's follow-up of the recommendations made by the committee of inquiry into BSE (A4-0362/97, 14.11.1997).

${ }^{607}$ Curtin describes ex post scrutiny as "ascertaining after the fact, to which extent the agent has lived up to its ex ante mandate". Curtin (2009), p. 250.
} 
basis. 608 The monthly progress reports were drawn up according to the structure of the list of recommendations of the inquiry committee. The rapporteur, Böge, considered these monthly Commission progress reports, used by the Parliament for the first time, to be a "valuable tool" since it enabled the temporary committee to deal with individual topics precisely and on a continuous basis. The Commission's positions were continuously developed and modified on the basis of the discussions in the special committee. ${ }^{609}$

The BSE follow-up committee had close contacts with members of the Commission, particularly with Emma Bonino (Health and Consumer Protection), who made herself available for discussions with the committee on many occasions. The main contact in its day-to-day work was Horst Reichenbach, the Director General of Bonino's Directorate General, who attended all committee meetings. ${ }^{610}$ When required - particularly in presenting the monthly progress reports - the Directors General of other DGs concerned (or their representatives) also attended the committee meetings. The attendance of Commission Directors General was anything but a routine event at that time. Böge observed: "these Director Generals initially did not know how to deal with the Parliament due to the fact that this form of parliamentary scrutiny was new. In this sense, the BSE follow-up committee has managed to create a new culture of parliamentary scrutiny". ${ }^{611}$

The committee also held discussions with the representatives of the Commission's Legal Service, the Commission's Inspectorate General, the EU's anti-fraud unit (UCLAF) and the Chairman of the Commission's Multidisciplinary Scientific Committee, which addressed the multi-disciplinary aspects of the BSE epidemic. ${ }^{612}$ The committee held a final exchange of views with the President of the Commission, Jacques Santer, in October 1997. The committee also invited Commissioners Oreja, Fischler and Liikanen to discuss particular relevant points. There was an exchange of views with the British Minister for Agriculture, Jack Cunningham, the successor to Douglas Hogg (who had refused to appear before the BSE inquiry committee ${ }^{613}$ ), and with the President of the Council of Agricultural Ministers, the Luxembourg Minister for Agriculture, Fernand Boden. In addition to its external contacts, the BSE follow-up committee involved MEPs from relevant standing committees (Budgets, Research and Environment) in its work. ${ }^{614}$

The committee was also involved in the preparation of the International Scientific Conference on Meat-and-Bone Meal, held in Brussels in July 1997.

608 European Parliament (1997). BSE follow-up committee. Report on the European Commission's follow-up of the recommendations made by the committee of inquiry into BSE (A4-0362/97, 14.11.1997), p. 27.

${ }^{609} \mathrm{Ibid}$. p. 27.

${ }_{610} \mathrm{Ibid}$. pp. 27-28.

${ }^{611}$ Interview with Reimer Böge, 21 June 2011.

${ }_{612}$ European Parliament (1997). BSE follow-up committee. Report on the European Commission's follow-up of the recommendations made by the committee of inquiry into BSE (A4-0362/97, 14.11.1997), p. 28.

${ }^{613}$ Cf. Section 2.5.2.3.

${ }_{614}$ European Parliament (1997). BSE follow-up committee. Report on the European Commission's follow-up of the recommendations made by the committee of inquiry into BSE (A4-0362/97, 14.11.1997), p. 28. 
For this purpose, it established a four-person working group, comprising vicechair Jové Peres; the rapporteur, Böge; and the coordinators, Graefe zu Baringdorf and Whitehead. The group had several meetings with the Commission officials from the DGs responsible for organizing the conference. The results of the conference were summarized by the rapporteur in a working document ${ }^{615}$ and were reproduced at some points in the BSE follow-up committee's final report (in particular under 3.7 and 3.8). ${ }^{616}$

At the invitation of the British Minister for Agriculture, Cunningham, a committee delegation made an on-the-spot visit in September 1997 to learn about the implementation of BSE-related measures in the United Kingdom and the monitoring of them by the Commission. The delegation consisted of the committee chair, one of the vice-chairs (Santini), the rapporteur and the committee members Corrie, Graefe zu Baringdorf, Kofoed, and Whitehead. Horst Reichenbach, Director-General of DG XXIV, accompanied the delegation as a guest. ${ }^{617}$ Visits were made to the port of Dover, a dairy farm, a slaughterhouse, a meat-and-bone meal plant, a meat-and-bone meal store, and an incineration plant for meat-and-bone meal. The delegation was thus given the opportunity to obtain comprehensive and practical information about the existing BSE-related problems. In addition there were opportunities for talks with the Minister for Agriculture, Cunningham, and representatives of the British victims of the 'human BSE', the new variant of the Creuzfeldt Jacob disease. Rapporteur Böge observed that the visit to the UK took place in an open and constructive atmosphere. He went on to say that representatives of the British Ministry of Agriculture were always available to answer additional questions and to take part in expert discussions. The rapporteur noted that members who had been part of the delegation from the committee of inquiry into BSE, which visited the United Kingdom in December 1996, commented favourably on the improvements in atmosphere and content since the previous visit. ${ }^{618}$

\subsubsection{The committee's final report}

On 14 November 1997, the BSE follow-up committee submitted its report to the Parliament. The committee observed that, given the timeframe generally required for European policy changes, it could not expect that all of the recommendations of the BSE committee would be fully implemented within six months. It concluded, however, that "a great deal of progress" had been made in a relatively short time. ${ }^{619}$ The Commission had implemented most of the recommendations in full or in part. ${ }^{620}$ This applied in particular to the dramatic reorganization of its departments. In order to avoid future intermingling of economic and public health interests, the Commission had placed all seven

\footnotetext{
615 Working Document No 2 of 7 July 1997, PE 221.144.

616 European Parliament (1997). BSE follow-up committee. Report on the European Commission's follow-up of the recommendations made by the committee of inquiry into BSE

(A4-0362/97, 14.11.1997), p. 28.

617 Ibid. p. 28.

618 Ibid. pp. $28-29$.

619 Ibid. p. 50.

620 Ibid. p. 50.
} 
scientific, veterinary and food committees advising on public health, as well as a special unit to evaluate public health risks under the authority of the Directorate General responsible for Consumer Affairs (DG XXIV), and it had almost doubled its staff of 140 officials. ${ }^{621}$ At the same time, DG XXIV was renamed the Directorate-General on Consumer Policy and Consumer Health Protection (now DG SANCO). ${ }^{622}$ The BSE follow-up committee furthermore praised the Commission's efforts to improve transparency, the initiation of proceedings for infringement of the Treaties, its legislative initiatives (the Commission had submitted proposals for application of the co-decision procedure in agricultural matters to the Intergovernmental Conference), and the future strengthening of cooperation on veterinary checks. ${ }^{623}$

Notwithstanding its positive overall impression, the BSE follow-up committee noted that five recommendations (of a total of over sixty) had not been implemented due to "fundamental disagreement" between the Parliament and Commission on these points. ${ }^{624}$ These 'problematic' recommendations were:

- the submission of legislative proposals with a view to making the authorities which had allowed the disease to appear and spread responsible for the financial costs of $\mathrm{BSE}^{625}$;

- the adoption of the necessary personnel and disciplinary measures with regard to the incorrect behaviour of Commission officials ${ }^{626}$;

- the bringing of administrative proceedings against the United Kingdom for repayment of all sums allocated in previous years for the purposes of eradicating $\mathrm{BSE}^{627}$;

- the institution of proceedings against the UK government in the European Court of Justice on the basis of Article 3 (2) IIA and Article 169 of the EC Treaty (at present: Article $258 \mathrm{TFEU}$ ) on account of the failure of the UK Minister of Agriculture to appear before the committee of inquiry ${ }^{628}$; and

- proposals to the Intergovernmental Conference for an amendment of the Treaty enabling a motion of censure to be tabled against individual members of the Commission. ${ }^{629}$

\footnotetext{
${ }_{621}$ Vos (2000), p. 234; Harlow (2002), p. 100; Chambers (1999), p. 105; Shackleton (1998), p. 125; Maurer (2007), p. 96.

${ }^{622} \operatorname{Vos}(2000)$, p. 234.

${ }^{623}$ European Parliament (1997). BSE follow-up committee. Report on the European Commission's follow-up of the recommendations made by the committee of inquiry into BSE (A4-0362/97, 14.11.1997), p. 50.

${ }^{624}$ Ibid. p. 50.

${ }^{625} \mathrm{Ibid}$. pp. 41-42.

${ }^{626}$ Ibid. pp. 42-44.

${ }^{627}$ Ibid. pp. 44-45.

${ }^{628}$ Ibid. p. 46.

${ }^{629} \mathrm{Ibid}$. p. 47.
} 


\subsubsection{Plenary debate of 18 November 1997}

The BSE follow-up committee's report was debated in plenum on 18 November 1997.630 The chairwoman, Roth-Behrendt, pointed out that, although the debate was about the Commission, she would prefer to talk about the Council:

"if we thought and are still thinking about a possible vote of no confidence, the Council would have deserved this vote of no confidence [...] but if we as the European Parliament, out of all the institutions, can only speak about the Commission, and evaluate what the Commission has achieved in the last halfyear, the assessment [...] shows very clearly that things are moving! Suddenly movement is there. Suddenly transparency is there. Suddenly an effort by the Commission can be recognized. Effort! That is a word we never heard in the early years, since 1987/1988, in connection with BSE. Where once there was cover-up, now there is transparency. There could not be a bigger contrast. And suddenly the efforts are achievable, to an extent that no member of the BSE follow-up Committee, in any group, had believed possible six months ago. We would never have believed that we would get to where we are. All the committee members said that they did not trust the Commission to move in this way. Neither did I, to be honest! That it took the threat of a vote of no confidence to get the Commission moving or to put it under pressure, is regrettable on the one hand, but gratifying on the other, because it shows what a Moloch like the Commission can achieve if it has to".

The chairwoman, however, acknowledged that there were still "perhaps few, perhaps not the most important" unfulfilled demands of the European Parliament.

In his speech to the Parliament, the President of the Commission, Santer, mentioned the five recommendations which the Commission had not implemented. On the recommendation to institute proceedings against the UK Government on account of Douglas Hogg's refusal to appear before the BSE inquiry committee, he (rightly) stated: "Legally, according to our interpretation, such a recourse would have no chance of success". Santer, however, pointed out that he supported the Parliament's demand for the obligatory appearance of government members of Member States before committees of inquiry of the European Parliament, and that he advocated a revision of the Interinstitutional Agreement on this point. On the recommendation to enable Parliament to censure individual Commissioners, Santer responded: "the Commission would not want to abandon the essential principle of collective responsibility. It is the guarantee of the independent exercise of the Commission's responsibilities in the general interest. Any sanction against the Commission, just like its responsibilities, could only be collective and collegiate". At the end of his speech, Santer reiterated the Commission's full commitment to continuing "the fruitful cooperation" with the Parliament within the context of the work of its standing committees.

630 The transcripts of the plenary debate of 18 November 1997 are online available under: http://www.europarl.europa.eu/calendar/calendar?APP=DEBATS\&LANGUE=EN (click on '18 November 1997' and subsequently on 'BSE'). 
Notwithstanding the five recommendations which had not been implemented by the Commission, the Parliament's overall impression of the Commission's follow-up to the recommendations of the BSE committee was positive. The threat to censure the Commission was therefore withdrawn and the committee's report was adopted with an overwhelming majority (427 in favour, 33 against, 45 abstentions). The importance of such a large majority should not be underestimated. In this respect, Böge observed: "As a matter of course opinions differed between the political groups on the question which way forward regarding BSE. However, like in the BSE inquiry committee, the special committee managed to reach a compromise which attracted wide support in the Parliament. That is the formula for success. A coincidental majority does not suffice if the Parliament really wants to achieve something. Only an overwhelming majority will be taken seriously by the Commission and the Council". ${ }^{631}$

\subsubsection{Follow-up to the investigation}

Even after the work of the BSE follow-up committee had ended, the Parliament kept a constant eye on the BSE issue. Its demand to put public health and consumer protection under the co-decision procedure was ultimately complied with in the Treaty of Amsterdam. This Treaty, which was signed on 2 October 1997, could not have been discussed at a better time for the Parliament. It was commonly known that France was opposed to the idea of giving the Parliament a strong say in the legislative process for public health and consumer protection. However, France ultimately gave in to the enormous public pressure which had arisen as a consequence of the BSE crisis and it accepted that these matters would be transferred from the consultation procedure to the co-decision procedure (at present: the ordinary legislative procedure). ${ }^{632}$

In 2001 the Parliament and the Council laid down rules in a regulation for the prevention, control and eradication of certain transmissible spongiform encephalopathies ('TSEs'), including BSE. ${ }^{633}$ The regulation established, for the first time, a uniform legal basis for the control and prevention of TSEs by consolidating all previous EU legislation governing TSEs. In addition, the Parliament and the Council concluded a regulation in 2004 introducing official controls for the verification of compliance with feed and food law, animal health and animal welfare rules. ${ }^{634}$

The (standing) committee on the Environment, Public Health and Food Safety (ENVI committee) of the Parliament adopted a report in 2011 in which it took stock of the measures taken following the BSE crisis. ${ }^{635}$ The rapporteur of the report was Dagmar Roth-Behrendt (PES), who had previously chaired the BSE follow-up committee. Roth-Behrendt was satisfied with the fact that the number of positive BSE cases in the EU had decreased from 2167 in 2001 to 67

\footnotetext{
${ }^{631}$ Interview with Reimer Böge, 21 June 2011.

632 Ibid.

${ }^{633}$ Regulation (EC) No 999/2001 of the European Parliament and the Council of 22 May 2001.

${ }^{634}$ Regulation (EC) No 882/2004 of the European Parliament and the Council of 29 April 2004.

${ }^{635}$ Cf. Section 4.4.4.
} 
in 2009. She considered this important evidence that the EU's TSE eradication measures had been successful. ${ }^{636}$ Reimer Böge, who chaired the BSE inquiry committee and who was the rapporteur of the BSE follow-up committee, agreed with Roth-Behrendt. According to Böge, the legislation accounted for the fact that the EHEC virus, which had caused the death of dozens of people (mainly) in Germany in 2011, could be traced considerably quicker than would have been the case without the new rules. ${ }^{637}$

\subsubsection{Echelon}

\subsubsection{Subject, establishment and duration of the investigation}

There was initial debate in the Parliament on the kind of temporary committee that should be established to investigate the existence of the Echelon interception system. Two proposals were put before Parliament: one to establish a committee of inquiry and another to establish a special committee. Only the latter proposal gained majority support at the plenary session of 5 July 2000.

The establishment of the special committee was prompted by two studies commissioned by STOA $^{638}$ concerning the so-called Echelon system. The author of the first STOA report (of 1997) claimed that all e-mail, telephone and fax communications in Europe were routinely intercepted by the US National Security Agency. As a result of this report, the alleged existence of a comprehensive global interception system called Echelon was brought to the attention of people throughout Europe. The name Echelon was used to describe an intelligence collection and analysis network operated on behalf of the five signatory states to the UKUSA Agreement (Australia, Canada, New Zealand, the United Kingdom and the United States). The second STOA report (of 1999) suggested that Echelon had moved away from its original purpose of defence against the Eastern Bloc and was currently being used for industrial espionage. Examples of alleged industrial espionage were given in support of the claim. In particular, it was stated that Airbus and Thomson CFS had been damaged as a result. James R. Woolsey, the former director of the CIA, reacted to the STOA report in March 2000: “The European Parliament's recent report on Echelon [...] has sparked angry accusations [...] that U.S. intelligence is stealing advanced technology from European companies so that we can [...] give it to American companies and help them compete. My European friends, get real. True, in a handful of areas European technology surpasses American, but $[\ldots]$ the number of such areas is $[\ldots]$ very small. Most European technology just isn't worth our stealing. Why, then, have we spied on you? The answer is [...] (that) we have spied on you because you bribe". ${ }^{639}$ Concerns

636 European Parliament (2011). ENVI committee. Report on EU legislation on Transmissible Spongiform Encephalopathies (TSE) and on related feed and food controls implementation and outlook (A7-0195/2011, 26.5.2011), p. 10.

637 Cf. Interview with Reimer Böge, 21 June 2011.

638 STOA (Scientific and Technological Options Assessment) is a department of the Directorate-General for Research of the European Parliament which conducts research at the request of parliamentary committees.

639 Woolsey (2000). 
over the alleged existence and use of this Echelon system led to the establishment of the Echelon committee. ${ }^{640}$

The Echelon committee was composed of 36 full members and 33 substitutes. The committee started its work in September 2000 under the chairmanship of the Spanish MEP Carlos Coelho (EPP) and the German MEP Gerhard Schmid (PES) as rapporteur. The Echelon committee was mandated:

“- to verify the existence of the communications interception system known as ECHELON, whose operation is described in the STOA report published under the title 'Development of surveillance technology and risks of abuse of economic information';

- to assess the compatibility of such a system with Community law, in particular Article 286 of the EC Treaty and Directives 95/46/EC and $97 / 66 / \mathrm{EC}$, and with Article 6(2) of the EU Treaty, in the light of the following questions:

- are the rights of European citizens protected against activities of secret services?

- is encryption an adequate and sufficient protection to guarantee citizens' privacy or should additional measures be taken and if so what kind of measures?

- how can the EU institutions be made better aware of the risks posed by these activities and what measures can be taken?

- to ascertain whether European industry is put at risk by the global interception of

communications;

- possibly, to make proposals for political and legislative initiatives." $64 \cdot 1$

The Echelon committee submitted its report to the plenary in July 2001, one year after its establishment. ${ }^{642}$

\subsubsection{Committee proceedings}

The Echelon committee held its constituent meeting on 9 July 2000 and published its final report one year later, on 11 July 2001. Thirteen meetings were held, at the rate of roughly one per month.

The Echelon committee was not tasked with proving the existence of the Echelon interception system, but rather with identifying whether or not it existed at all. Wiersma (a member of the Echelon committee) and Van de Water (an assistant to the PSE group in the Parliament) observed that the committee rejected the attitude of trying to declare the US guilty as quickly as

${ }_{640}$ European Parliament (2001). Echelon committee. Report on the existence of a global system for the interception of private and commercial communications (ECHELON interception system) (Part 1, A5-0264/2001, 11.7.2001), pp. 21-22.

${ }^{641}$ Decision to set up the special committee into Echelon (OJ C 121, 24.4.2001, p. 131).

${ }_{642}$ European Parliament (2001). Echelon committee. Report on the existence of a global system for the interception of private and commercial communications (ECHELON interception system) (Part 1, A5-0264/2001, 11.7.2001). 
possible, and that it was determined not to give in to media pressure to come up with 'James Bond-stories'. The committee rather preferred a meticulous working method, trying to establish bit by bit, step by step, whether or not Echelon actually existed.643 To that end, a programme of work proposed by the rapporteur was adopted by the committee. The programme of work listed nine topics which were to be investigated: 1. Certain knowledge about Echelon; 2. Debate by national parliaments and governments; 3 . Intelligence services and their operations; 4. Communications systems and the scope for interception ; 5 . Encryption; 6. Industrial espionage; 7. Aims of espionage and protective measures; 8. Legal context and protection of privacy, and 9. Implications for the EU's external relations. ${ }^{644}$ The topics were considered consecutively at the individual meetings. By way of preparation for the meetings, the rapporteur systematically scrutinized and evaluated the material available. Wiersma and Van de Water observed that the committee members became fascinated by the matters under investigation and that there was even competition between members to find relevant information first. ${ }^{645}$

\section{Gathering of information}

In accordance with the requirements of the nine topics listed by the rapporteur, the committee invited witnesses to attend committee meetings. ${ }^{646}$ A total of 84 persons were heard by the committee, of which 28 were heard during factfinding visits to Paris, London and Washington DC. The Echelon committee held talks with:

- $\quad$ representatives of national administrations (particularly secret services);

- representatives of national parliaments in their capacity as bodies responsible for monitoring secret services;

- legal experts;

- experts in the fields of communications and interception technology, business security and encryption technology with both academic and practical backgrounds;

- journalists and authors who had investigated Echelon;

- three Commissioners (Christopher Patten (External Relations), António Vitorino (Justice and Home Affairs), and Erkki Liikanen (Enterprise and the Information Society));

- high officials of the Commission;

- representatives of the Council presidency-in-office;

- Council officials;

${ }_{643}$ Wiersma/Van de Water (2001), p. 25.

${ }_{644}$ European Parliament (2001). Echelon committee. Report on the existence of a global system for the interception of private and commercial communications (ECHELON interception system) (Part 1, A5-0264/2001, 11.7.2001), p. 23.

${ }_{645}$ Wiersma/Van de Water (2001), p. 27.

${ }_{646}$ European Parliament (2001). Echelon committee. Report on the existence of a global system for the interception of private and commercial communications (ECHELON interception system) (Part 1, A5-0264/2001, 11.7.2001), p. 23. 
- $\quad$ ECB officials; and

- $\quad$ a Council of Europe official. ${ }^{647}$

The meetings were generally held in public, although some sessions were also held behind closed doors where this was felt to be advisable in the interests of obtaining information. ${ }^{648}$ The committee used its sessions in November 2000 to hear representatives of national parliaments. The British and Danish parliaments refused to participate in these meetings. The sessions were also used to question national civil servants. Wiersma and Van de Water described the evidence giving of Ernst Uhrlau, Coordinator of the Intelligence Community within the German Federal Chancellor's Office as a highlight. Uhrlau provided the committee, albeit in camera, with useful information on the abilities and limitations of the German Federal Intelligence Service ('Bundesnachrichtendienst') in intercepting international communications"'.649

In the January 2001 session, the rapporteur, Schmid, introduced a Draft Interim Document to the committee. The committee had an exchange with authors, writers and journalists specialized in Echelon-related issues. Two of the five persons invited did not manage to attend the meeting. Further experts and Commission officials were heard during the February 2001 session. It is worth mentioning the hearing of high Commission official Desmond Perkins, who testified in his capacity as Head of the Commission's Cyber Office. To the surprise of the committee members, Perkins declared that the US routinely inspected the European Commission's encryption system. "I have always had very good contacts with the NSA in Washington, and they usually check our systems to see that they are being well looked after and not being misused", he said. The Commission immediately reacted by stating that Perkins' words had been misunderstood. The Commission denied that the US had access to the Commission's encryption methods or could decode its messages.

Meanwhile, there were developments in unravelling the mystery of Echelon. Whereas the existence of Echelon had previously been categorically denied by official authorities, things started to change in the early part of 2001. In February 2001, for example, the Dutch government reported, after years of denying the existence of Echelon, to the Dutch parliament: "Although the Dutch government does not have official confirmation of the existence of Echelon by the governments related to this system, it thinks it is plausible this network exists. The government believes not only the governments associated with Echelon are able to intercept communication systems, but that it is an activity of the investigative authorities and intelligence services of many countries with governments of different political background". ${ }^{650}$

\footnotetext{
${ }^{647}$ A list of experts who appeared before the Committee can be found in the final report: European Parliament (2001). Echelon committee. Report on the existence of a global system for the interception of private and commercial communications (ECHELON interception system) (Part 1, A5-0264/2001, 11.7.2001), pp. 150-152.

648 Ibid. p. 23.

649 Wiersma/Van de Water (2001), p. 27.

650 Letter from Frank de Grave, the Dutch Defence minister, of 19 January 2001. Cf. Proceedings of the Dutch Lower House of the States-General 2000-2001, 27 591, nr. 1.
} 


\section{Fact-finding visits}

In addition to the committee hearings, the committee chairman and the rapporteur visited London and Paris to meet people who for a wide variety of reasons were unable to attend meetings with the committee but whose involvement in the investigation nonetheless seemed advisable. During the visit to Paris on 18-19 January 2001, the chairman and the rapporteur held talks with officials from the French secret service, the Sécretariat Générale de la Défense Nationale (SGDN) and civil servants working in the ministries of Interior Affairs and Defence.651 One week later, the chairman and the rapporteur visited London, where they met several House of Commons committee chairs. They further held talks with inter alia the Secretary of State of the Home Department and the Security Service Coordinator. ${ }^{652}$ By so doing, the committee managed to gather information from persons who, due to the initial refusal of the British parliament to cooperate in the course of the investigation, otherwise would not have held talks with the Echelon committee. The committee's bureau, the coordinators and the rapporteur made the third, and last, fact-finding visit to Washington DC, where meetings with representatives of the Congressional Oversight committee, the US Administration, and NGOs were scheduled. Due to a last-minute cancellation, the meetings with the US Department of State, the Advocacy Centre of the Department of Commerce, the CIA and the NSA could not take place. The committee chairman deplored this last-minute cancellation. ${ }^{653}$ He stressed the political significance of the cancellation of these meetings and the "coincidence" that they had all been cancelled simultaneously without satisfactory explanation. ${ }^{654}$ The cancellation of the meetings raised suspicions within the committee that there was something to hide. ${ }^{655}$ The other meetings (with the committee of Congress responsible for monitoring the secret services, with representatives of the US Department of Justice, with former CIA director James R. Woolsey and with representatives of US civil society) were not cancelled. According to the chairman, these conversations had been frank and cordial. ${ }^{656}$ Wiersma and Van de Water observed that the working method of the committee proved successful: "Especially the cooperation with members of national parliaments had been stimulating. Reports on the limited success of investigatory committees of the French, Belgian and Italian parliaments made clear that those committees only revealed few new facts. Their own secret services hardly cooperated throughout the investigations, let alone the foreign secret services. It became clear that the national parliaments placed their hope

\footnotetext{
651 European Parliament (2001). Echelon committee. Report on the existence of a global system for the interception of private and commercial communications (ECHELON interception system) (Part 1, A5-0264/2001, 11.7.2001), p. 152.

652 Ibid. p. 152.

653 Roxburgh (2001).

654 Minutes of the Echelon committee meeting of 15 May 2001. Online available under: http://www.europarl.europa.eu/comparl/tempcom/echelon/minutes.htm.

655 See also: Wiersma/Van de Water (2001), p. 62.

656 Minutes of the Echelon committee meeting of 15 May 2001. Online available under: http://www.europarl.europa.eu/comparl/tempcom/echelon/minutes.htm.
} 
in the committee of the European Parliament, which strengthened its will to do better and to reveal harder and more facts". ${ }^{657}$

\subsubsection{The committee's final report}

On 11 July 2001, the Echelon committee adopted its final report and recommendations for submission to the Parliament.658 The findings, the conclusions, and the recommendations are discussed hereafter. The minority opinions of committee members are discussed subsequently.

\section{The committee's findings and conclusions}

After twelve months of investigative work, the Echelon committee concluded that the existence of a global interception system used by the USA, the UK, Canada, Australia and New Zealand was no longer in doubt. The committee observed: "It may be assumed, in view of the evidence and the consistent pattern of statements from a very wide range of individuals and organizations, including American sources, that the system or parts of it were, at least for some time, code-named ECHELON. What is important is that its purpose is to intercept private and commercial communications, and not military communications. Analysis has revealed that the technical capabilities of the system are probably not nearly as extensive as some sections of the media had assumed. Nevertheless, it is worrying that many senior Community figures, in particular European Commissioners, who gave evidence to the Temporary Committee, claimed to be unaware of this phenomenon". ${ }^{659}$

Concerning the technical possibilities of the interception system, the committee ascertained that the majority of communications cannot be intercepted by earth stations, but only by tapping cables and intercepting radio signals. The committee noted that the UKUSA states only have access to a very limited proportion of cable and radio communications, and owing to the large numbers of personnel required, they can only analyse an even smaller proportion of those communications. It went on to say that the extremely high volume of traffic meant that exhaustive, detailed monitoring of all communications is impossible in practice. ${ }^{660}$

The committee stated that an intelligence system is at odds with the Member States duty of loyal cooperation and with the concept of a common market based on free competition if such a system is misused by an EU Member State

\footnotetext{
${ }_{657}$ Wiersma/Van de Water (2001), p. 27.

${ }_{658}$ The Committee's final report consists of two parts. Part 1 is the main part, containing the committee's findings, conclusions and recommendations. Cf. European Parliament (2001). Echelon committee. Report on the existence of a global system for the interception of private and commercial communications (ECHELON interception system) (Part 1, A50264/2001, 11.7.2001). Part 2 includes the minority opinions of committee members and some annexes with inter alia a list of witnesses who provided the committee with information. Cf. European Parliament (2001). Echelon committee. Report on the existence of a global system for the interception of private and commercial communications (ECHELON interception system) (Part 2, A5-0264/2001, 11.7.2001).

${ }_{659}$ European Parliament (2001). Echelon committee. Report on the existence of a global system for the interception of private and commercial communications (ECHELON interception system) (Part 1, A5-0264/2001, 11.7.2001), p.133.
}

${ }_{660}$ Ibid. p. 133. 
(the United Kingdom) for the purpose of gathering competitive intelligence. Any interception by such an intelligence system, the committee went on to say, moreover represents serious interference with an individual's right of privacy ex Article 8 of the European Convention on Human Rights (the ECHR). Such interference is only justified if it is 'prescribed by law', if it pursues a 'legitimate aim' and if it is 'necessary in a democratic society'. The committee concluded that an intelligence system which intercepts communications permanently and at random without legal basis clearly violates Article 8 ECHR. 661

Concerning the alleged industrial espionage through Echelon, the committee revealed that the US intelligence services do intercept communications between firms, particularly where contracts are being awarded, and that they justify this on the grounds of combating attempted bribery. The committee observed that detailed interception poses the risk that information may be used as competitive intelligence, rather than for combating corruption, even though the US and the United Kingdom state that they do not do so. Although it was frequently maintained that Echelon was used for economic reasons, the committee noted that no such case had been substantiated. 662

In short, the committee concluded that there is a global interception system, which, however, cannot intercept all communications, but which might be used to intercept both private and commercial communications.

The Echelon committee formulated 36 recommendations related to the following issues:

- the conclusion and amendment of international agreements on the protection of citizens and firms;

- $\quad$ national legislative measures to protect citizens and firms;

- $\quad$ specific legal measures to combat industrial espionage;

- measures concerning the implementation of the law and the monitoring of that implementation;

- $\quad$ measures to encourage self-protection by citizens and firms; and

- $\quad$ measures to improve security in the institutions. ${ }^{663}$

Seven members of the Echelon committee delivered minority opinions to the committee's final report. Giuseppe di Lello, Pernille Frahm, and Alain Krivine (GUE/NGL) stressed that an interception system such as Echelon infringes the citizens' right of privacy and they regretted the fact that "the European Union is more preoccupied with industrial espionage than with individual monitoring". ${ }^{664}$ Patricia McKenna and Ilka Schröder (Greens/EFA) assented to these statements. Furthermore, McKenna and Schröder considered it hypocritical for the European Parliament to criticize the Echelon interception practice while taking part in plans to establish a European Secret Service. They went on to say that: "No effective public control mechanism of secret services

\footnotetext{
${ }^{661} \mathrm{Ibid}$. pp. 133-134.

662 Ibid. p. 134.

${ }^{663}$ Ibid. pp. 10-20.

${ }_{664}$ European Parliament (2001). Echelon committee. Report on the existence of a global system for the interception of private and commercial communications (ECHELON interception system) (Part 2, A5-0264/2001, 11.7.2001), p. 4.
} 
and their undemocratic practices exists globally. It is in the nature of secret services that they cannot be controlled. They must therefore be abolished. This report serves to legitimise a European Secret Service which will infringe fundamental rights - just as Echelon does". 665 Jean-Charles Marchiani (UEN) showed himself dissatisfied with the final report: "From the outset, a majority within Parliament had clearly indicated its intentions, preferring to set up this temporary committee rather than a full-blown committee of inquiry. Accordingly, it had nothing else to fear from proceedings where the rapporteur's ability to create regular diversions was in no way threatened by a band of malcontents whose motives were too disparate. Our message is crystalclear: Mr Schmid's efforts have been unable to conceal either the existence of the Echelon system or the active or passive involvement of several Member States". ${ }^{666}$ Maurizio Turco (non-attached Member) ${ }^{667}$ was dissatisfied with the fact that no reference was made to the states which made use of interception systems as well, namely Germany, the Netherlands and, probably, France. Contrary to the solution presented in the final report, he further stated that better parliamentary scrutiny should help to promote the protection of privacy, not more powerful encryption methods. ${ }^{668}$

\subsubsection{Plenary debate of 5 September 2001}

The Echelon committee presented its report to the plenum during the session of 5 September 2001. The report was debated with Commissioner Erkki Liikanen (Enterprise and Information Society), and a representative of the (Belgian) Presidency-in-Office of the Council, Annemie Neyts-Uyttebroeck. The representative of the Presidency-in-Office of the Council complimented the Echelon committee on its work: "With this report by Mr Schmid drawn up on behalf of the Temporary ECHELON Committee, Parliament has more than met what is expected within the Union in terms of quality. Therefore, Parliament and the Schmid report are fundamental to greater awareness of this issue. The Council and the presidency, each within their own remit, will make every effort to guarantee fully respect for private and family life and data protection, both within the Union and elsewhere". ${ }^{669}$

Dybkjaer, a Danish MEP (ELDR) pointed out: "This is one of the best examples of the European Parliament's being able to make a difference and of its being able to perform a task which otherwise could not have been carried out because the individual parliaments would not have been up to the job".

Although not all speakers endorsed the conclusions and recommendations in the final report, there was wide agreement that the committee, and its

\footnotetext{
665 Ibid. p. 5.

666 Ibid. p. 6.

667 Non-attached Members of the European Parliament are so-called because they do not belong to one of the political groups. For further reading, Cf. Judge/Earnshaw (2008), pp.133-134.

668 European Parliament (2001). Echelon committee. Report on the existence of a global system for the interception of private and commercial communications (ECHELON interception system) (Part 2, A5-0264/2001, 11.7.2001), p. 6.

669 The literal transcripts of the plenary debate of 12 March 1997 are online available on the website of the European Parliament: http://www.europarl.europa.eu.
} 
rapporteur in particular, did a great job by proving the existence of Echelon. Commissioner Liikanen informed the Parliament of the steps the Commission was planning to take in response to the Echelon investigation. He announced inter alia that the Commission intended to allocate additional resources to security.

Directly after the debate, the Parliament endorsed the committee's report (367 votes in favour, 159 against and 39 abstentions). Caudron (PSE) added an explanation to his vote. He noted: "I was one of those who had called for a committee of inquiry. For the sake of efficiency, I then endorsed the idea of a temporary committee. Today, I have no regrets! Our committee (of which I was a member) did sterling work and Mr Gerhard Schmid, its rapporteur, proved highly capable. A few months ago, most of the political leaders quite simply denied the existence of Echelon. Now in early September 2001, everyone (or nearly everyone) recognises that this American illegal espionage network covers much of the world and is 'watching' the commercial markets and the citizens' private lives!".

MEPs called on the Member States to develop European encryption software and to raise awareness among the public and among companies of the need to protect themselves. The Commission was called on to strengthen its own security systems, and companies were invited to cooperate more closely with the counter-espionage services.

\subsubsection{Follow-up to the investigation}

The recommendations of the Echelon committee were ignored by most of the EU Member States. According to Wiersma this was hardly surprising because otherwise the Member States would have implicitly recognized the competence of the European Parliament in this intergovernmental domain.670 Wiersma observed that the Echelon investigation essentially was a consciousness-raising exercise concerning the vulnerability of communication systems. ${ }^{671}$ However, some concrete actions were taken by the Commission in response to the Echelon investigation. In answer to a parliamentary question from MEP Niall Andrews (UEN), the Commission reported that it had added security provisions in its internal rules, that it was implementing Regulation (EC) No $45 / 2001$ on the protection of individuals with regard to the processing of personal data by the Community institutions and bodies and on the free movement of such data, and that it had proposed Directive 2002/58/EC concerning the processing of personal data and the protection of privacy in the electronic communications sector, which subsequently had been adopted by the Parliament and the Council. ${ }^{672}$ The Commission went on to say that it set up the European Network and Information Security Agency (ENISA), with the purpose to "enhance the capability of the Community, the Member States and,

\footnotetext{
670 Wiersma (2004), p. 226.

${ }^{671}$ Interview with Jan Marinus Wiersma, 13 September 2011.

${ }^{672}$ Answer to the oral question of MEP Niall Andrews (UEN) (H-0 154/O4) by the European Commission, 22 April 2004.
} 
as a consequence, the business community to prevent, address and to respond to network and information security problems". ${ }^{673}$

\subsubsection{Foot-and-mouth disease}

\subsubsection{Subject, establishment and duration of the investigation}

At its plenary session of 16 January 2002, The European Parliament decided to set up a special committee on foot-and-mouth disease (hereafter: FMD). In 2001, outbreaks of FMD occurred in the United Kingdom, the Netherlands, and, on a smaller scale, in France and Ireland. A policy of large-scale slaughtering was preferred over vaccination of the animals. Since vaccination would have resulted in a complete ban on the use of the produce from vaccinated animals in the food industry, the majority of British farmers were opposed to vaccination. Millions of animals were slaughtered, which raised public concern throughout Europe and which also had a significant impact on the economy of the countries concerned. Concerns within the Parliament about the FMD crisis led to the establishment of the FMD committee.

The FMD committee was composed of 30 full members and 27 substitutes. The committee started its work in September 2000 and was chaired by the Spanish MEP Encarnación Redondo Jiménez (EPP). The rapporteur was the German MEP Wolfgang Kreissl-Dörfler (PES). The mandate of the FMD committee was:

"(a) to assess EU policy and the control of meat imports from third countries in the context of the epidemic;

(b) to analyse the management of the foot-and-mouth epidemic and the implementation of Community law in this regard to date, and to invite representatives of the Commission and of governments, as well as officials responsible, to attend hearings of the committee;

(c) to analyse the total impact on Community funds of the footand-mouth epidemic so far;

(d) on this basis to make proposals to look into vaccination policy in particular and for political and legislative initiatives with regard to the prevention and fighting of diseases in the agricultural sector in general”. ${ }^{674}$

\subsubsection{Committee proceedings}

The FMD committee held its constituent meeting on 21 February 2002 and published its final report nine months later, on 28 November 2002. A total of 21 meetings were held, at the rate of roughly two per month.

${ }^{673} \mathrm{Cf}$. Article 2 (1) Regulation (EC) No 460/2004 of the Parliament and of the Council of 10 March 2004 establishing ENISA.

${ }^{674}$ Decision of the European Parliament establishing a special committee on foot-and-mouth disease (OJ C 271, 7.11.2002, pp. 51-52). 


\section{Gathering of information}

The FMD committee heard a total of 93 persons. The diverse range of persons that gave evidence to the committee were:

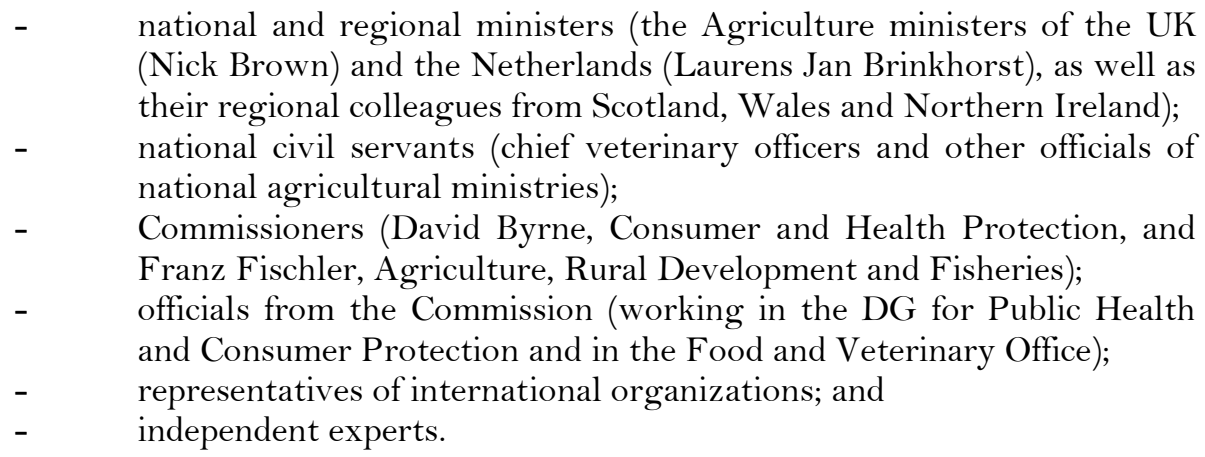

Most meetings (16 out of 21) were used to hear experts who were invited to speak on the various aspects covered by the committee's mandate.

\section{Fact-finding visits}

The FMD committee sent four delegations on fact-finding missions to the regions most severely affected by the FMD crisis. The north of England (Northumberland and Cumbria) and the south of Scotland were visited in April 2002. During this visit, the committee delegation held talks with farmers, veterinarians and local authorities (about 50 people in total) who were directly involved in the crisis. Farms were visited and at a public meeting anyone who wished to take the floor was invited to do so. The delegation also received twelve written submissions during the visit. 675

A committee delegation visited the Dutch provinces of Gelderland, Overijssel, Flevoland and Friesland in May of the same year. During this visit four public meetings were held, and the delegation visited three farms and the Central Institute for Animal Disease Control in Lelystad. The delegation spoke with a total of 30 people (farmers and veterinarians, but also a policeman, a school director, a minister, representatives of farmers' organizations and of local and regional authorities and a director of a zoo). The delegation received 34 written submissions and three petitions during the visit. About 700 members of the general public attended the meetings. ${ }^{676}$

The third fact-finding visit was made to Wales, Devon and Gloucestershire in June 2002. Seven public meetings were held. Twenty experts gave evidence to the delegation. A total of 400 people attended the meetings, of whom 80 members of the public requested the floor and were given the opportunity to speak. The delegation visited a farm as well as the Epynt disposal site and it received 34 written submissions. 677

\footnotetext{
${ }^{675}$ European Parliament (2002). FMD committee. Activity report (PE 319.300, 19.12.2002), p. 4.

${ }^{676}$ Ibid. p. 4.

${ }^{677}$ Ibid. p. 4.
} 
Finally, in September 2002, a committee delegation visited the port of Rotterdam in order to discuss the problem of meat and animal imports with domestic authorities. In a personal capacity, the chairman and the rapporteur visited various countries in Latin America (Argentina, Brazil, Uruguay and Paraguay) where they met national and regional authorities as well as farmers and representatives of farmers' organizations. The rapporteur also took the opportunity during his visit to South Africa to obtain information about South African policy on FMD. ${ }^{678}$

\subsubsection{The committee's final report}

The FMD committee adopted its report unanimously on 28 November 2002.679 The first part of the report is a motion for a resolution, in which the committee listed its conclusions and recommendations. ${ }^{680}$ The second part is an 'explanatory statement', which contains general information and findings of the committee.681

The FMD committee criticized the United Kingdom for inadequate handling of the FMD crisis. ${ }^{682}$ The committee was less critical with regard to the handling of the crisis in the Netherlands and France and it praised Ireland for its effective and efficient method of combating FMD. ${ }^{683}$ The FMD committee observed that the Commission responded to the crisis immediately and that it took the necessary decisions. It stressed, however, that the Commission failed to review the Member States' contingency plans within an appropriate timeframe following the introduction of the ban on prophylactic vaccination in 1992. At the time of the crisis it had still not reviewed the implementation either of the UK's contingency plan or of those of the Netherlands or France. ${ }^{684}$ In its motion for a resolution, the FMD committee formulated a large number of recommendations. The recommendations concerned inter alia prevention, contingency plans and methods of controlling animal diseases, import controls, compensation, and research and development. The committee was of the opinion that the basic non-vaccination policy had assigned undue priority to trade-policy aspects. ${ }^{685}$ In order to avoid similar mass slaughter in the future, the committee recommended that vaccination be considered a first-choice option in the event of an outbreak. 686

\subsubsection{Plenary debate of 17 December 2002}

The Parliament debated the FMD committee's report during its plenary session of 17 December 2002.

${ }^{678}$ Ibid. p. 4.

679 European Parliament (2002). FMD committee. Report on measures to control Foot and Mouth Disease in the European Union in 2001 and future measures to prevent and control animal diseases in the European Union (A5-0405/2002, 28.11.2002).

680 Ibid. pp. 5-29.

${ }^{681}$ Ibid. pp. 30-78.

682 Ibid. pp. 10-13.

${ }^{683}$ Ibid. pp. 13-15.

${ }^{684}$ Ibid. pp. 15-16.

${ }^{685}$ Ibid. p. 9.

${ }^{686}$ Ibid. p. 18. 
The contributions of two speakers underline the function which investigations by the European Parliament may have. Firstly, the contribution by Nick Clegg (ELDR): "I see that the PSE Group and the rapporteur have tabled some amendments to protect the reputation of the United Kingdom Government. I would only suggest to my colleagues that they should not be so over-sensitive. It is simply part and parcel of the independence of a committee of inquiry such as this that there should be some critical remarks. Frankly, it is an aspect of independence that the government has deliberately shunned by refusing to hold its own public inquiry in the UK". The latter sentence highlights one of the functions of investigations conducted by the European Parliament. Executive dominance on the national level may withhold national parliaments from investigating delicate issues. If such a delicate matter is not purely national in nature, the European Parliament can fill this national democratic gap on the European level by starting an investigation to clarify the issue. By so doing, it can ensure that matters of public concern do not get swept under a carpet of executive dominance at the national level. Where national parliaments fail to clarify delicate issues on behalf of their voters, the European Parliament may well be able to serve those same voters. The contribution by Jonathan Evans (EPP-DE) is linked to this observation: "I [ ...] want to begin by thanking the committee for visiting Welshpool, Builth Wells and Sennybridge and meeting people within my constituency who said to $\mathrm{Mr}$ Kreissl-Dörfler that the European Parliament was the only official body that came to listen to their views. That addresses, in my view, the issue of the relevance of the European Parliament. Setting up the committee has been a worthwhile exercise".

Directly after the debate, the Parliament endorsed the committee's report with an overwhelming majority (481 in favour, 32 against, 13 abstentions).

\subsubsection{Follow-up to the investigation}

Nine months after the FMD investigation, the Council adopted a Directive on foot-and-mouth disease.687 The preamble of the Directive states that "the Resolution of 17 December 2002 of the European Parliament on the foot-andmouth disease epidemic in 2001 in the European Union, based on the conclusions of the Temporary Committee on Foot-and-Mouth Disease of the European Parliament should be taken into account in this Directive". ${ }^{688}$ The Directive provides for measures to control and eradicate the disease with the aim of regaining the disease and infection-free status of the affected territory. The control measures are based on destroying infected and in-contact herds, which is at odds with the Parliament's recommendation to consider vaccination the first-choice option in the event of an FMD outbreak so as to avoid the mass

687 Council Directive 2003/85/EC of 29 September 2003 on Community measures for the control of foot-and-mouth disease repealing Directive 85/511/EEC and Decisions 89/531/EEC and 91/665/EEC and amending Directive 92/46/EEC (OJ L 306, 22.11.2003, p. 2$)$.

${ }_{688}$ Council Directive 2003/85/EC of 29 September 2003 on Community measures for the control of foot-and-mouth disease repealing Directive 85/511/EEC and Decisions 89/531/EEC and 91/665/EEC and amending Directive 92/46/EEC (OJ L 306, 22.1 1.2003, p. 2). 
slaughter of infected herds. ${ }^{689}$ In line with the Parliament's recommendations, however, the Directive includes provisions on the use of emergency vaccination and it obliges Member States to have contingency plans.

\subsubsection{Improving safety at sea}

\subsubsection{Subject, establishment and duration of the investigation}

At its plenary session of 6 November 2003, the Parliament set up a special committee on improving safety at sea. On 19 November 2002, the oil tanker Prestige sank off the coast of Galicia, Spain. This caused an ecological and economic disaster which particularly hit the fishing industry and tourism in Galicia and neighbouring regions. The oil spread over a large area and caused pollution not only on the coast of Spain but also on those of France and Portugal. Immediately after the sinking of the Prestige, the European Parliament adopted two resolutions expressing its concern about the developing ecological disaster. On 19 and 20 March 2003, the Parliament held a public hearing with various experts in Brussels and a parliamentary delegation visited the affected area in Galicia in March 2003, followed by a visit to various maritime organizations and institutes in Brest, France. The findings were recorded in a report and the Parliament adopted a resolution on 23 September 2003 calling for the establishment of a temporary committee on improving safety at sea.690 Six weeks later such a temporary committee was established.

The Improving Safety at Sea committee was composed of 44 full members and 34 substitute members. The committee started its work in November 2003 and it was chaired by the German MEP Georg Jarzembowski (EPP-ED). The establishment of a special committee was also a compromise. Spanish MEPs from the EPP-ED group were not favourably disposed to an investigation of any kind into the Prestige disaster because of a fear that the centre-right Spanish government would then inevitably be closely scrutinized. Left-wing Spanish MEPs, however, advocated the establishment of a committee of inquiry. The middle course was adopted by establishing a special committee. According to Dirk Sterckx, the committee's rapporteur, this was the right decision: "A heated discussion within Parliament on whether or not to establish a committee of inquiry would cost a lot of energy and it would mean that you fight a political war even before the actual investigation starts. At the end of such a political fight, there is always a group of winners and a group of losers in Parliament, which would definitely not contribute to a successful inquiry”. ${ }^{691}$ After the decision was taken to set up a special committee, a new discussion arose in the Parliament. Both Spanish camps within the Parliament - the centre-right allies of the Spanish government, and the oppositional left-wing MEPs - had their eyes on the role of the rapporteur on the committee so as to

689 European Parliament (2002). FMD committee. Report on measures to control Foot and Mouth Disease in the European Union in 2001 and future measures to prevent and control animal diseases in the European Union (A5-0405/2002, 28.11.2002), p. 18.

${ }^{690}$ Cf. European Parliament (2004). Committee on Improving Safety at Sea. Report on improving safety at sea (A5-0257/2004, 7.4.2004), p. 14.

${ }^{691}$ Interview with Dirk Sterckx, 30 May 2011. 
be able to steer the final report into their respective directions. In order to prevent a one-sided report and constant wrangling over every single issue, the Parliament chose to adopt a middle course by appointing a rapporteur who was neither Spanish, nor member of one of the two largest political groups, namely the Belgian Liberal Dirk Sterckx (ELDR). 692

According to Jan Marinus Wiersma, a member of this special committee, the ultimate mandate of the committee illustrates the fact that temporary committees always have a political background and that they do not only emanate from sheer indignation over a particular event. Wiersma describes how the then centre-right Spanish Government of José Maria Aznar, which was criticized heavily for the Prestige disaster, mobilized its political friends in the European Parliament to broaden the mandate of the special committee. As a consequence, the mandate concentrated not only on the details of recent maritime disasters, but also on wider, future-oriented issues. During the special committee's work, Aznar's allies in the Parliament continued to stress that the committee should look at the future, whereas MEPs from Spanish oppositional parties wanted to put the spotlight exclusively on the disaster itself. Wiersma rightly notes that the aim should be to combine a thorough ex post investigation of such disasters with advancing recommendations for the prevention of such disasters in the future. ${ }^{693}$ The special committee's mandate was:

“(a) to examine in detail maritime disasters, in particular the Prestige, the Erika and other recent accidents and incidents; (b) to further analyse their social and economic consequences, with regard in particular to fisheries, industry and tourism, as well as the environment and health;

(c) to assess maritime safety standards more generally and the application of these standards by the Member States in compliance with EU and international law;

(d) to seek to ensure implementation of the recommendations contained in its resolution of 23 September 2003;

(e) to propose additional measures which are found to be necessary." 694

The Improving Safety at Sea committee completed its final report in April 2004.

\subsubsection{Committee proceedings}

Between November 2003 and April 2004, the committee held seven meetings, at the rate of roughly one per month. At the outset of the investigation, the committee adopted a working programme which reflected the committee's

\footnotetext{
${ }^{692}$ Cf. Interview with Dirk Sterckx, 30 May 2011.

693 Wiersma (2004), p. 226.

694 European Parliament (2004). Committee on Improving Safety at Sea. Report on improving safety at sea (A5-0257/2004, 7.4.2004), p. 14.
} 
mandate. The committee meeting of December 2003 was devoted to part A and $\mathrm{B}$ of the mandate. Part $\mathrm{C}$ was dealt with in the January 2004 meeting, and part $\mathrm{D}$ and $\mathrm{E}$ were handled in the course of the February 2004 meeting. The rapporteur subsequently presented a draft report to the committee at the March 2004 meeting. The committee adopted the final text one month later, in April 2004.

The committee did not analyze the Prestige and the Erika maritime disasters with a view to finding out who was to blame for these accidents. These incidents were rather an interesting subject of investigation because lessons could be learned from them for the future. The chairman said that the committee would above all investigate how existing EU legislation on maritime safety was implemented into national legislation by the Member States. He went on to say that it was the committee's top priority to ensure that maritime disasters like those involving the Prestige or the Erika would never happen again. ${ }^{695}$

The Improving Safety at Sea committee gathered oral information from 28 persons. Talks were held with:

- The Vice-President of the European Commission, Ignacia Loyola de Palacio (Energy and Transport);

- Officials from the European Commission (working in the DGs Environment and Regional Policy);

- The Irish President-in-Office of the Transport Council, Dermot Ahern;

- The executive director of the European Maritime Safety Agency (EMSA), Willem de Ruiter;

- The captain of the Prestige, Apostolos Mangouras;

- The chairman of the French Assembly's inquiry committee on maritime safety, Edouard Landrain;

- National civil servants (such as the representative of the Bahamas maritime authority (the flag state of the Prestige), the Spanish government commissioner on the Prestige disaster, the Director of the Irish Coastguard, and a UK Secretary of State representative);

- Representatives of various organizations (such as the World Wildlife Fund (WWF) and the International Maritime Organization (IMO);

- Independent experts.

\section{Fact-finding visits}

The captain of the Prestige, Apostolos Mangouras, was the only person who held talks with the committee outside Brussels. Since the Prestige disaster in November 2002, the Greek captain had been under house arrest pending his trial in Spain. The Spanish judicial authorities did not react to a request made by the committee to grant Mangouras authorization to leave Spain for an

${ }_{695}$ Published on the website of the Improving Safety at Sea committee, available online under: http://www.europarl.europa.eu/comparl/tempcom/mare/pdf/news__en.pdf. 
exchange of views with the committee in Brussels. ${ }^{696}$ Mangouras and his lawyer subsequently informed the committee that they were prepared to meet a committee delegation in Barcelona, albeit under certain conditions. The meeting should take place in camera and the committee's delegation should be limited to eight MEPs. Furthermore, no interpretation should take place and questions were only to be asked in English by one speaker from the delegation. ${ }^{697}$ A committee delegation, composed of the chair, the rapporteur, and four other MEPs ${ }^{698}$, subsequently held an interview with Mangouras in Barcelona in February 2004. At this meeting, the captain answered questions on a range of issues. Mangouras told the delegation inter alia that an enormous environmental maritime disaster could have been prevented if the Spanish authorities had allowed him to take his ship to a place of refuge. But to his surprise, the authorities had ordered a tugboat to pull the ship in a northerly and later in a north-westerly direction, where the Prestige ultimately sank. ${ }^{699}$ A few days after the visit to Barcelona, on 10 February 2004, the Parliament received a rejection from the Spanish judicial authorities to the request to authorize Mangouras to travel to Brussels. ${ }^{700}$ The visit to Barcelona was the only fact-finding visit conducted by the committee.

\subsubsection{The committee's final report}

The Improving Safety at Sea committee adopted its final report on 7 April 2004.701 The committee criticized the Spanish authorities for the decisions taken before, during and after the Prestige oil tanker disaster. Particular condemnation was expressed for the decision to tow the vessel away from the coast, and for the Spanish authorities' statement that they would take the same action again. ${ }^{702}$ The committee further deplored the fact that the captain of the Prestige, Apostolas Mangouras, was not being allowed to leave Spain pending his trial. It called on the Spanish judicial authorities to allow Mangouras to return to his country pending his trial, to relax the requirement that he report daily to the authorities, and to clarify the starting date and timetable for the legal case against him as soon as possible. ${ }^{703}$

Before the accident, there were 77,000 tonnes of heavy oil on board the Prestige. According to the Spanish authorities' statistics, 14,000 tonnes

696 European Parliament (2004). Committee on Improving Safety at Sea. Report on improving safety at sea (A5-0257/2004, 7.4.2004), p. 14.

${ }_{697} C f$. the Minutes of the meeting of 18 February 2004 in Brussels. Available online under: http://www.europarl.europa.eu/meetdocs/committees/mare/20040308/525150en.pdf.

698 Rosa Miguelez Ramos (PES), Carlos Ripoll Y Martinez De Bedova (EPP-ED), Camilo Nogueira Roman (Greens/EFA), and Koldo Gorostiaga Atxalandabaso (Ind).

${ }^{699}$ Cf. EP Press Release of 18 February 2004 ('Meeting of MEPs with Prestige captain in Barcelona').

700 European Parliament (2004). Committee on Improving Safety at Sea. Report on improving safety at sea (A5-0257/2004, 7.4.2004), p. 15.

701 Ibid.

702 This statement was made during the Committee meeting of 2 December 2003 by the Spanish government commissioner responsible for dealing with the Prestige, Mr. Uría Fernández.

703 European Parliament (2004). Committee on Improving Safety at Sea. Report on improving safety at sea (A5-0257/2004, 7.4.2004), pp. 6-7. 
remained and some 43,000 tonnes had been cleaned up after the accident. This left 20,000 tonnes unaccounted for. The committee expressed concern regarding the probability that these 20,000 tonnes were still left in Galician waters. ${ }^{704}$

The committee further called on Member States to set up a European coastguard service with the powers to ensure: (1) maritime safety and the protection of the marine environment (including fisheries, piracy, maritime crime and terrorism), (2) the strict monitoring of adherence to certain shipping routes and prosecution for the illegal entry of vessels, (3) swift coordination of measures in the event of an accident at sea, including the assignment of emergency moorings and ports. ${ }^{705}$ Other recommendations included a call for more powers for the European Maritime Safety Agency (EMSA), improved working conditions and safety for seafarers and better protection of the Baltic waters, given that many Russian oil tankers do not meet EU safety standards. ${ }^{706}$ Rapporteur Sterckx observed that the Improving Safety at Sea committee managed to resist the temptation to call for drastic measures. "We concluded that most rules were there, but that the implementation of these rules had been inadequate", he said.707

\section{Remarks by the rapporteur}

At the end of the report, rapporteur Sterckx added some remarks quoted here at length regarding the usefulness of the committee's work:

"Your rapporteur observes that the setting-up of the MARE committee (i.e. the special committee on improving safety at sea, C.N.S) made it possible for the European Parliament to build further on the work already done in preparation for the first Prestige report. At the three public hearings and during the interview with the master of the Prestige, useful additional information was presented concerning both the Prestige disaster (and its handling) and the scope for improving safety at sea in Europe and worldwide. For half a year, the MARE committee also provided a framework in which policy-makers from, inter alia, the EP, Council, Commission, EMSA and IMO could exchange views on ways of improving safety at sea. This guaranteed constant political attention for maritime safety. Sometimes it also yielded direct results. For example, Commissioner De Palacio and IMO SecretaryGeneral Mitropoulos took the opportunity provided by their attendance at one of the public hearings to reach practical agreement, in the margins of the meeting, on further cooperation between their organizations. The MARE committee accordingly proved its usefulness as an international forum.

The MARE committee and this report also provided an opportunity to evaluate the extent to which the recommendations made in the Prestige report of September 2003 had already been translated into policy. In a number of cases the conclusions were positive: measures have been taken, for instance, to ban old single-hulled tankers carrying heavy oil from European waters and a

\footnotetext{
${ }^{704}$ Ibid. p. 6.

705 Ibid. p. 8.

${ }^{706}$ Ibid. pp. 8-12.

${ }^{707}$ Interview with Dirk Sterckx, 30 May 2011.
} 
good deal of progress has been made with the conferral of additional powers on EMSA.

Moreover, the Commission has announced that during 2004 it will submit a package of supplementary measures which will fulfil a number of the EP's previous requests. [...]. However, the European Parliament's recommendations have not yet been acted upon in all respects. For example, some Member States have not yet complied with their legal obligation to designate ports of refuge and draw up emergency plans; this was one of the most important points in the resolution of September 2003. The Council has also made little or no progress with other elements, such as membership of the IMO for the Union and penalties for polluting the sea. In the motion for a resolution, your rapporteur therefore reiterates various requests which have been made previously, as well as making a number of new recommendations". ${ }^{708}$

\subsubsection{Plenary debate of 20 April 2004}

The report of the Improving Safety at Sea committee was debated in plenum on 20 April 2004. Most speakers were favourable towards the committee's report. The Spanish authorities were criticized for the handling of the Prestige accident and most speakers supported the suggestion to set up a European coastguard service. Both the Parliament and the Commission (represented by its Vice-President Loyola de Palacio), however, did not have high expectations of the Council for the handling of the recommendations outlined in the report.

Speaking on behalf of the rapporteur, Herman Vermeer (ELDR) said that the committee had made an important step towards safer seas. He hoped that the implementation of these recommendations would prevent more Erika and Prestige-like disasters in the near future.

Miguélez Ramos (PES) observed that the Parliament proved its value by establishing the special committee: "The institution [...] carried out its responsibility for political monitoring of what was and continues to be a European disaster that goes beyond the limits of a single Member State and took on board the consequences by promoting the sea traffic policy, which is the responsibility of Community and international bodies, although the decisions to implement it are left in the hands of the leaders of the Member States."

Several speakers posed questions to the Commission regarding the fate of captain Mangouras. To these questions, the Vice-President of the Commission, De Palacio, rightly replied: "the Commission is not able to intervene in the legal systems of the Member States. Neither can the governments intervene in the legal decisions of the Member States. There is a separation of powers. In this respect, I suspect, as has already been indicated, that a political change in the Spanish Government will have little effect on the opinion of the judge on duty. It would be catastrophic and disastrous if the judge on duty were to obey the political impulses of the ideals of the government in power".

708 European Parliament (2004). Committee on Improving Safety at Sea. Report on improving safety at sea (A5-0257/2004, 7.4.2004), p. 16. 
The Parliament approved the committee's report with 396 votes in favour, 24 against and 13 abstentions. Given the controversy in the Parliament prior to the investigation, especially between the Spanish members of the two largest political groups, this is an overwhelming majority. The Spanish MEPs from the EPP-ED group indeed voted against the final report, but the fact that the other members of their group voted in favour indicates that rapporteur Sterckx succeeded in writing a report which enjoyed wide support throughout the Parliament.

\subsubsection{Follow-up to the investigation}

Even before the investigation was over, the Commission had promised to submit a new package of measures to improve safety at sea. The Commission fulfilled this promise in 2005 when it submitted the "Third package of legislative measures on maritime safety in the European Union'709 to the Parliament, in which it built on the conclusions of the Improving Safety at Sea committee. ${ }^{710}$ According to the rapporteur of the special committee, this 'Third package' may be attributed largely to the Improving Safety at Sea committee. Sterckx went on to say that the European Parliament "would not have achieved this if it had established a committee of inquiry on this matter". ${ }^{711}$

Along with other measures, the Commission launched a specific programme to monitor the conformity and application of the maritime safety legislation. The Commission pointed out that this programme had already resulted in an increase in the number of infringement procedures brought against Member States, as requested by the Parliament. ${ }^{712}$

\subsubsection{CIA flights}

\subsubsection{Subject, establishment and duration of the investigation}

At its plenary session of 18 January 2006, the European Parliament set up a special committee on the alleged use of European countries by the CIA for the transport and illegal detention of prisoners (hereafter: CIA flights committee). In the autumn of 2005, statements by American officials, newspaper reports and allegations made by NGOs referred to the existence of secret CIA detention centres in Europe, illegal abductions and the ill-treatment of prisoners. ${ }^{713}$ These allegations raised concerns within the Parliament and led to the establishment of the CIA flights committee. ${ }^{714}$

\footnotetext{
${ }^{709}$ European Commission (2005). Third package of legislative measures on maritime safety in the European Union (COM/2005/585, 23.11.2005).

${ }_{710}$ Ibid. pp. 2-3.

711 Interview with Dirk Sterckx, 30 May 2011.

712 European Commission (2005). Third package of legislative measures on maritime safety in the European Union (COM/2005/585, 23.11.2005), p. 5.

713 A chronology of events which raised concerns within the European Parliament was drawn up by the rapporteur, Giovanni Claudio Fava; $C f$. European Parliament (2006). CIA Flights committee. Working document No 2 on a chronology of events (PE 374.338, 1.6.2006).

${ }^{714}$ Section 3.5.8 discussed in more detail the reasons for setting up this special committee.
} 
The CIA flights committee was composed of 46 full members and 46 substitute members. The committee started its work in January 2006, and was chaired by the Portuguese MEP Carlos Coelho (EPP-ED). The rapporteur was the Italian MEP Giovanni Claudio Fava (PES).

The mandate of the CIA flights committee was:

“(a) to collect and analyse information to find out whether:

- the CIA or other US agents or intelligence services of other third countries have carried out abductions, 'extraordinary rendition', detention at secret sites, detention incommunicado or torture or other cruel, inhuman or degrading treatment of prisoners on the territory of the European Union, including accession and candidate countries, or have used that territory to those ends, for example through flights;

- such actions, allegedly carried out in the territory of the European Union in the framework of the fight against terrorism, could be considered a violation inter alia of Article 6 of the Treaty on European Union, Articles 2, 3, 5 and 6 of the European Convention for the Protection of Human Rights and Fundamental Freedoms, the Charter of Fundamental Rights, the UN Convention against Torture and Other Cruel, Inhuman or Degrading Treatment or Punishment, the EU-US agreements on extradition and on mutual legal assistance and other international treaties and agreements concluded by the European Union/Community and its Member States, including the North Atlantic Treaty and its related agreements on the status of forces and the Convention on International Civil Aviation;

- citizens of the European Union or the candidate countries, or any other person entitled to protection from, or otherwise under the jurisdiction of, the EU, the Member States or the candidate countries have been among those involved in or subjected to abductions, 'extraordinary rendition' operations, detention at secret sites, detention incommunicado or torture or other cruel, inhuman or degrading treatment in the territory of the European Union or elsewhere;

- Member States, public officials, persons acting in an official capacity or European Union institutions have been involved or complicit in the illegal deprivation of liberty of individuals, including abduction, rendition, transfer, detention or torture, either by act or omission;

(b) to submit to the plenary any recommendation that the committee deems necessary in this matter, notably concerning the political, legal and administrative conclusions to be drawn at the 
European level as well as possible consequences for EU relations with third countries;"715

The CIA flights committee finished its final report in January 2007.

\subsubsection{Committee proceedings}

The CIA flights committee held its constituent meeting on 26 January 2006 and adopted its final report on 23 January 2007. A total of 33 meetings were held, at the rate of roughly three per month. As a general rule, committee meetings were held in public, except where there was explicit need for a meeting behind closed doors.

At the outset of the investigation, the committee approved a working document drafted by the rapporteur. ${ }^{716}$ The working document prescribed close cooperation with the Council of Europe, national governments and national parliaments. It further suggested that EU Member States and third countries, especially those where parliamentary inquiries were being conducted, be asked to provide all relevant information to the CIA flights committee. ${ }^{717}$ The rapporteur further suggested organizing fact-finding visits to the United States and to other countries. The working document contained a list of persons to be heard in the course of the investigation, divided into eight categories: (1) Council of Europe, (2) EU institutions, (3) UN High Commissioner for human rights, (4) Human Rights organizations, (5) Member States' (and other countries') officials, (6) journalists, (7) witnesses, and (8) victims. ${ }^{718}$

The topic under investigation was highly controversial within the Parliament. At the outset of the investigation, the largest political group (EPP-ED) denied the possibility of illegal CIA practices on European territory. This changed somewhat in September 2006, when US President George W. Bush officially confirmed that the CIA was operating a secret detention programme outside the USA. Nevertheless, the EPP-ED group remained unsympathetic towards the CIA investigation. According to Sophie in 't Veld (ALDE) - who was a member of the CIA flights committee - the MEPs of the two largest groups were particularly reluctant to investigate the actions of national governments that their respective parties were part of. ${ }^{719}$

\section{Oral evidence}

The CIA flights committee heard evidence from 173 persons. ${ }^{720}$ These persons were heard both during committee meetings in Brussels and in the course of

\footnotetext{
715 European Parliament decision setting up a temporary committee on the alleged use of European countries by the CIA for the transportation and illegal detention of prisoners (OJ C 287 E, 24.11.2006, p. 159).

716 European Parliament (2006). CIA Flights committee. Working document on TDIP Temporary Committee work programme (PE 370.642, 14.2.2006).

717 Ibid. p. 3.

718 Ibid. pp. 6-8.

719 Interview with Sophie in 't Veld, 4 July 2011.

720 A list is provided in the final report of the CIA flights Committee. Cf. European Parliament (2007). CIA Flights committee. Report on the alleged use of European countries
} 
fact-finding visits by the committee. The diverse range of persons that gave evidence to the committee consisted of:

- Franco Frattini, vice-President of the European Commission;

- Javier Solana, EU High Representative for the CFSP;

- the EU's Counter-terrorism Coordinator;

- $\quad$ several national ministers;

- $\quad$ heads of national intelligence services;

- a former CIA director;

- presidents of national parliaments;

- members of national parliaments (such as chairmen of inquiry committees);

- national prosecutors;

- $\quad$ the Secretary-General of the Council of Europe;

- $\quad$ high officials of international organizations (such as the UN);

- $\quad$ alleged victims of CIA-practices (and their lawyers);

- $\quad$ people working for NGOs (such as Amnesty International and Human Rights Watch);

- journalists; and

- academics.

There were, however, also a large number of persons who refused a request to give evidence to the CIA flights committee. ${ }^{721}$ Among the 71 persons who declined to give evidence were the former and the current Secretary-General of NATO, a large number of national ministers, and a large number of Members of the US House of Representatives and US Senate. Many of these persons gave no reason for their refusal. Others declared that they did not have time, that they were not authorized by their superiors, or that they could not give evidence due to a policy of confidentiality. The Austrian and the Polish ministers of Foreign Affairs and the Danish Minister of Transportation refused to appear before the committee because they were of the opinion that they did not have additional relevant information. ${ }^{722}$

Sophie in ' $t$ Veld (ALDE) observed that authorities (such as the Council, the Member State governments, the EU High Representative for the CFSP, the EU's Counter-terrorism Coordinator and NATO) were not ready to cooperate with the CIA flights committee. They preferred to sweep the issue of illegal CIA activities under the carpet. However, In ' $t$ Veld noted that on several occasions relevant information reached the CIA flights committee through anonymous sources. ${ }^{723}$

by the CIA for the transportation and illegal detention of prisoners (A6-0020/2007, 30.1.2007), pp. 50-63.

${ }^{721}$ A list of persons who refused to cooperate with the CIA flights Committee is provided in the CIA flights Committee's final report. $C f$. European Parliament (2007). CIA Flights committee. Report on the alleged use of European countries by the CIA for the transportation and illegal detention of prisoners (A6-0020/2007, 30.1.2007), pp. 70-76.

${ }_{722}$ Cf. Ibid.p. 70.

${ }^{723}$ Interview with Sophie in 't Veld, 4 July 2011. 


\section{Fact-finding visits}

The CIA flights committee sent seven delegations on fact-finding missions. The delegations visited Skopje, Washington DC, Berlin, London, Bucharest, Warsaw and Lisbon to hold talks with a wide range of persons, varying from members of national parliaments to alleged victims of CIA practices. ${ }^{224}$ The experiences were reported to the other members of the CIA flights committee after each fact-finding visit. These reports contained summaries of the hearings held during the visits and general remarks regarding the visits. After the visit to Washington DC, the chairman of the committee reported that the availability of the US Administration and of Congress had been far better than he had experienced during the visit of the temporary committee on Echelon to Washington DC in 2001.725

\subsubsection{The committee's final report}

The CIA flights committee adopted its final report on 30 January 2007.726 The report, which was adopted with 28 votes in favour, 17 against and 3 abstentions, consists of a draft motion for a resolution and four annexes, including an overview of the committee's activities (Annex I), an overview of the persons the committee had heard (Annex II), the degree of cooperation shown by national governments (Annex III), and a list of people who declined to cooperate in the course of the investigation (Annex IV).

\section{Cooperation by national governments}

At the start of the investigation, the committee chairman sent a letter to all permanent representatives of the Member States, in which he requested the Member States (and Turkey) to forward relevant information regarding the committee's mandate to the committee. In Annex III of its final report, the committee gives an overview of the response to this letter. ${ }^{727}$ The overview shows that 15 out of 28 (Member) States did not even reply. Eight Member States provided the committee with information which the committee considered "useful". A short remark should, however, be made here. At the same time as the parliamentary investigation into the CIA flights issue was taking place, the Council of Europe conducted an investigation on the same issue. ${ }^{728}$ Three of the Member States which provided the parliamentary

${ }^{724}$ A list of persons who held talks with the CIA flights Committee is provided in the CIA flights Committee's final report. Cf. European Parliament (2007). CIA Flights committee. Report on the alleged use of European countries by the CIA for the transportation and illegal detention of prisoners (A6-0020/2007, 30.1.2007), pp. 60-63.

725 European Parliament (2006). CIA Flights committee. Notice to members (376.444, 5.7.2006), p. 31.

726 European Parliament (2007). CIA Flights committee. Report on the alleged use of European countries by the CIA for the transportation and illegal detention of prisoners (A60020/2007, 30.1.2007).

727 Ibid. pp. 64-69.

728 This investigation was conducted by the Committee on Legal Affairs and Human Rights of the Parliamentary Assembly of the Council of Europe. The rapporteur of the Committee was Dick Marty (Switzerland); Cf. Council of Europe Parliamentary Assembly (2006). Committee on Legal Affairs and Human Rights. Alleged secret detentions in Council of Europe Member States (22.1.2006). 
committee with useful information on the CIA flights issue did no more than send a copy of the information they had previously sent to the Council of Europe.

Michael Shackleton suggested that the CIA flights committee did not add very much to the work that had already been done by Dick Marty on behalf of the Parliamentary Assembly of the Council of Europe.729 This view was partially refuted by Sophie in 't Veld, who observed: "The investigations of the Council of Europe and the European Parliament were complementary. Dick Marty, due to his stronger legal powers, was able to gather the lion's share of the evidence, but it was the European Parliament which managed to place the illegal CIA activities in Europe on the political agenda". 730

\section{The committee's findings, conclusions, and recommendations}

The CIA flights committee concluded that European countries had "turned a blind eye" to flights operated by the CIA which "on some occasions, were being used for extraordinary rendition or the illegal transportation of detainees". ${ }^{731}$ The committee stated that in some cases "temporary secret detention facilities in European countries may have been located at US military bases" and "there may have been a lack of control" over such bases by European host countries.732 The committee revealed that at least 1245 CIA flights flew into European airspace or stopped over at European airports between the end of 2001 and the end of 2005. It noted, however, that not all of those flights had been used for extraordinary rendition purposes.733 The committee mentioned 21 welldocumented cases of extraordinary rendition where the victims were transferred through a European country. With this in mind, the committee called on the European countries involved to compensate the innocent victims of extraordinary renditions. ${ }^{734}$ The committee deplored the renditions "as an illegal instrument used by the USA in the fight against terrorism" and it condemned the "acceptance and concealing of the practice, on several occasions, by the secret services and governmental authorities of certain European countries". 735 They therefore called on the Council and the Member States "to issue a clear and forceful declaration calling on the US Administration to put an end to the practice of extraordinary arrests and renditions". ${ }^{736}$

On the use of torture, the committee noted that the majority of cases involved incommunicado detention and torture during interrogations, as was confirmed by the victims and/or their lawyers who testified to the committee. ${ }^{737}$ In the light of the available evidence, the committee concluded that there was a

\footnotetext{
${ }^{729}$ Interview with Michael Shackleton, 15 April 2010.

${ }^{730}$ Interview with Sophie in 't Veld, 4 July 2011.

731 European Parliament (2007). CIA Flights committee. Report on the alleged use of European countries by the CIA for the transportation and illegal detention of prisoners (A60020/2007, 30.1.2007), p. 11.

732 Ibid. p. 24.

${ }^{733}$ Ibid. p. 11.

${ }^{734}$ Ibid. p. 29.

${ }^{735}$ Ibid. p. 11.

${ }_{736}$ Ibid. p. 6.

${ }^{737}$ Ibid. p. 11.
} 
"strong possibility that some European countries may have received [...] information obtained under torture". ${ }^{738}$

The committee further deplored the lack of cooperation by many Member States and the Council in the course of the investigation. It observed that "the serious lack of concrete answers to the questions raised by victims, NGOs, media and parliamentarians has only strengthened the validity of already welldocumented allegations". ${ }^{739}$ The committee deemed it "wholly unacceptable" that the Council initially withheld and then provided only partial information pertaining to regular discussions with high-level US officials. ${ }^{740}$ The committee observed that the duty of loyal cooperation had not been respected. ${ }^{741}$ The governments of Austria, Italy, Poland, Portugal and the UK were specifically criticized for their unwillingness to cooperate in the course of the investigation. The committee also complained about "omissions" in statements by Javier Solana, the Council's High Representative for the CFSP, on the Council's discussions about fighting terrorism with US representatives. Mr Solana, the committee observed, "was unable to supplement the evidence already in the possession of the temporary committee". ${ }^{742}$ The committee finally elaborated on its own position. It stressed: "In view of the powers it was provided with and of the time which it had at its disposal, and the secret nature of the investigated actions, that the Temporary Committee was not put in a position fully to investigate all the cases of abuses and violations falling within its remit and that its conclusions are therefore not exhaustive". ${ }^{743}$ This conclusion led to the following recommendation regarding the right of inquiry of the European Parliament: "the powers of Parliament's temporary inquiry committees should be reinforced and the inter-institutional decision governing the exercise of Parliament's right of inquiry be amended accordingly". ${ }^{744}$ The CIA flights committee did not elaborate on how the interinstitutional agreement should be amended. It did, however, touch upon the treatment of confidential information. Because the CIA flights committee felt hampered at several points by the national governments' refusals to provide the committee with information, the committee considered it necessary "to review by limiting and restrictively defining the exceptions that flow from the notion of 'State secret', also in the framework of the impending review of Regulation 1049/01745, as well as the adoption of common principles by the EU institutions as regards the treatment of confidential information, to avoid abuses and deviations that are more and more unacceptable in modern democratic States and that

\footnotetext{
738 Ibid. p. 5.

739 Ibid. p. 7.

${ }^{740}$ Ibid. p. 8.

${ }_{741}$ Ibid. p. 33.

${ }_{742}$ Ibid. p. 8.

743 Ibid. p. 33.

${ }_{744}$ Ibid. p. 30.

${ }_{745}$ Regulation (EC) No 1049/2001 of the European Parliament and of the Council of 30 May 2001 concerning public access to European Parliament, Council and Commission documents (OJ L 145, 31.5.2001, pp. 43-48).
} 
contradict human rights obligations". ${ }^{746}$ The committee therefore deemed it necessary: "to establish specific mechanisms to allow for access to secret information by parliaments and judges, as well as for the release of the information after a certain period of time". ${ }^{747}$

The CIA flights committee further encouraged governments and/or national parliaments to launch (or to pursue) independent investigations into the precise nature of CIA activities on their territory. ${ }^{748}$ The committee also formulated a large number of recommendations which were directly connected to the object of investigation. ${ }^{749}$

\subsubsection{Plenary debate of 14 February 2007}

On 14 February 2007, the committee's final report was debated in plenary, in presence of the Vice-President of the Commission, Franco Frattini, and a representative of the German Council Presidency, Günter Gloser.

Carlos Coelho, the chairman of the committee, thanked the Commission for its "outstanding" cooperation throughout the investigation. However, he condemned the lack of cooperation from the Council, which sent the committee "truncated, incomplete documents, passing them off as authentic and original", which Coelho considered "unacceptable under the principle of close collaboration between the institutions". Furthermore, Coelho was disappointed by the poor degree of cooperation shown by several Member States. Günter Gloser, representing the German Council Presidency, went further into this matter. Gloser denied the allegation that Member States failed to cooperate in the course of the investigation. He stressed that in many areas investigated by the CIA flights committee, especially the monitoring of intelligence services, the EU has no power to act. Therefore, with the subsidiarity principle in mind, he observed that the national level, not the European level, is the right level at which to hold such investigations.

The plenary debate showed that the Parliament was divided into roughly two camps on the CIA flights committee's draft report: one which supported the draft report and another which claimed that the report made many accusations based on little evidence. There were also several MEPs who claimed that there was nothing new in the report that was not already in the report the Council of Europe had adopted at an earlier stage. However, ultimately a parliamentary majority adopted the committee's report amidst considerable media interest. The result of the vote (382 votes in favour, 256 against and 74 abstentions) indeed shows that the Parliament was divided into two camps. The PES group accounted for the largest number of 'yes' votes whereas members of the EPPED group voted in large numbers against the report.

\footnotetext{
${ }^{746}$ European Parliament (2007). CIA Flights committee. Report on the alleged use of European countries by the CIA for the transportation and illegal detention of prisoners (A60020/2007, 30.1.2007), p. 29.

${ }^{747} \mathrm{Ibid}$. p. 29.

748 Ibid. p. 29.

749 Ibid. pp. 28-34.
} 


\subsubsection{Follow-up to the investigation}

In February 2008, one year after the investigation, the former rapporteur of the CIA flights committee, Claudio Fava (PES), proposed carrying out a second report taking into account recent developments and inquiries into abductions and renditions flights. He also wanted to document what actions Member State governments, the Commission and the Council had taken in response to the recommendations made by the CIA flights committee. However, MEPs from the centre-right EPP-ED political group opposed this idea arguing that there was no new information to record. ${ }^{750}$ Furthermore, it was said that the German and Swedish Socialist MEPs were also reluctant to carry out a follow-up report because they wanted to avoid damaging figures in their national parties. ${ }^{751}$ There was thus no majority in the Parliament in favour of preparing a second report on the CIA flights issue.

In February 2009, two years after the investigation, the Parliament adopted a resolution in which it denounced "the lack of action taken so far by the Member States and the Council to shed light on the extraordinary rendition programme and to implement Parliament's recommendations". ${ }^{752}$ The resolution had been adopted after new evidence had been found at the Member State level confirming the conclusions of the CIA flights committee.

In January 2011, the Parliament organized a workshop on the follow-up to the CIA flights investigation. Julia Hall (Amnesty International) and Manfred Nowak (a former UN Special Rapporteur on Torture) presented reports to the Parliament which concluded that the CIA flights investigation had not been properly followed up. ${ }^{753}$

In conclusion, it seems that the CIA flights investigation was a consciousnessraising exercise regarding illegal CIA activities on EU territory, but that its conclusions and recommendations did not land on fertile soil in the Council and the individual EU Member States. However, in a similar way as for the Echelon investigation, one of the reasons for this may be that Member States want to avoid an implicit recognition of the competence of the European Parliament in this intergovernmental domain.

\subsection{Gathering of information}

The five case studies above demonstrate that special committees, like committees of inquiry, collect their information through oral hearings, requests for written information, and on-the-spot fact-finding visits.

\subsubsection{Oral information}

Special committees make full use of their ability to invite persons to appear before them. As shown in Section 2.4.4.1 for committees of inquiry, this section

\footnotetext{
${ }^{750}$ Crosbie (2008).

751 Brunsden (2008).

752 European Parliament resolution of 19 February 2009 on the alleged use of European countries by the CIA for the transportation and illegal detention of prisoners (OJ C 76E, pp. 51-54).

${ }^{753}$ EP Press Release of 26 January 2011 ('More follow-up needed to secret rendition practices says report').
} 
distinguishes between three categories of person from whom oral evidence can be gathered: (1) members of an institution or a body of the European Union or the government of a Member State, (2) officials and servants, and (3) other persons.

\section{Members of an institution or a body of the European Union or the government of a Member State}

Special committees frequently organize hearings with members of the Commission. The case studies show that the close ties between the Parliament and the Commission ensure the presence of Commissioners before special committees on the latter's request.

The picture is, however, somewhat different for national ministers. Like the committees of inquiry, the special committees faced some difficulties when they tried to gather oral information from national ministers (whether or not in their capacity as members of the Council). It is true that many national ministers did appear before special committees, and that some of them proved cooperative in the course of investigations. ${ }^{754}$ However, the CIA flights investigation in particular showed that there is another side to the coin. A large number of national ministers declined to give information to the CIA flights committee. Some of them gave no reason for their refusal. Others declared that they did not have time, that they were not authorized by their superiors, that they could not give information due to a policy of confidentiality, or that they just did not have relevant information. ${ }^{755}$ However, it is by all means reasonable to argue that Member State authorities were neither legally, nor morally, obliged to cooperate in the CIA flights case, as this case lay beyond the scope of the European Parliament's sphere of competence. The CIA flights issue mainly centred on the question of whether national administrations (even of non-EU Member States) had been involved in secret CIA activities on the territory of the European Union. This falls under the Common Foreign and Security Policy (CFSP), which is an intergovernmental policy area in which the Parliament only plays a marginal role and where national parliaments seem to be the appropriate forums to hold 'their' respective national governments to account.

\section{Officials and servants}

Special committees make full use of their ability to hear both national and EU civil servants. The Echelon committee managed to hear a large number of representatives of national administrations. Many of them were working for the secret services. This special committee further heard several high officials

\footnotetext{
${ }^{754}$ For example, in the course of the investigation into the foot-and-mouth disease outbreak, when the Agriculture ministers of the UK (Nick Brown) and the Netherlands (Laurens Jan Brinkhorst), as well as their regional colleagues from Scotland, Wales and Northern Ireland made themselves available for the special committee. $C f$. European Parliament (2002). FMD committee. Activity report (PE 319.300, 19.12.2002), p. 1.

${ }^{755} \mathrm{~A}$ list of persons who refused to cooperate with the CIA flights Committee is provided in the CIA flights committee's final report. $C f$. European Parliament (2007). CIA Flights committee. Report on the alleged use of European countries by the CIA for the transportation and illegal detention of prisoners (A6-0020/2007, 30.1.2007), pp. 70-76.
} 
from the Commission, the Council and the ECB. The FMD committee heard the chief veterinary officers and other officials from national agricultural ministries and Commission officials working in the DG for Public Health and Consumer Protection and in the Food and Veterinary Office. The Improving Safety at Sea committee managed to talk to the Spanish government's commissioner on the Prestige disaster. The CIA flights committee heard the EU's Counter-terrorism Coordinator, several heads of national intelligence services and national prosecutors.

The special committees thus managed to obtain oral information from a wide range of officials and servants, both on the national and the EU level. Given the fact that many of these officials and servants - particularly those working for secret services - were not even under a duty to give information to a committee of inquiry, that may be seen as quite a satisfying result for the special committees.

\section{Other persons}

The special committees further heard numerous persons whom cannot be linked to one of the two categories discussed above. This last group consists inter alia of members of national parliaments, technical experts, academic experts, journalists, authors, and representatives of NGOs and other types of organization.

The Human Genetics committee and the Climate Change committee heard a large number of external experts who informed them on the rather technical issues under investigation. The special committees into the foot-and-mouth disease outbreak and the CIA flights also offered victims of foot-and-mouth disease and of alleged CIA practices the opportunity to give an account of their experiences. The Improving Safety at Sea committee arranged meetings with representatives of various organizations (such as the World Wildlife Fund (WWF) and the International Maritime Organization (IMO)). The CIA flights committee had to deal with many refusals to testify before it. The then Secretary-General of NATO, Jaap de Hoop Scheffer, and his predecessor, Lord Robertson, and a large number of Members of the US House of Representatives and US Senate refused to talk to the special committee. ${ }^{756}$ Many of them gave no reason for their refusal.

\subsubsection{Written information}

Special committees also collected written information. Sometimes the written information reached the special committees following a request, as was the case for numerous expert studies which were commissioned by special committees. The Council of Europe conducted an investigation into the alleged CIA practices in Europe at the same time as the CIA flights committee. The Parliament's committee relied heavily on the findings of the Council of Europe's investigative committee. ${ }^{757}$ The BSE follow-up committee organized

\footnotetext{
${ }^{756}$ Ibid. 9.

${ }^{757}$ This investigation was conducted by the Committee on Legal Affairs and Human Rights of the Parliamentary Assembly of the Council of Europe. The rapporteur of the Committee was Dick Marty (Switzerland); cf. Council of Europe Parliamentary Assembly (2006).
} 
its work on the basis of written information submitted to it by the Commission. The Commission informed the special committee via monthly progress reports providing an overview of the measures it had taken on the committee's recommendations. ${ }^{758}$ The rapporteur of the special committee considered the progress reports a "valuable tool", since it enabled the temporary committee to deal with individual topics precisely and on a continuous basis. ${ }^{759}$

Sometimes written information reached the special committees without an explicit request being made. The CIA flights committee received written information from anonymous sources, and the FMD committee collected a large part of its written information ( 80 written submissions and three petitions) in the course of its fact-finding visits.

\subsubsection{Fact-finding visits}

Like committees of inquiry, special committees undertake on-the-spot factfinding visits in the course of their investigations. Such fact-finding visits mainly serve two purposes. Firstly, fact-finding visits enable members of the committees to view specific locations in person. Secondly, these visits enable the committees to hold talks with persons who normally for different reasons would not have come to a committee meeting in the European Parliament.

A delegation from the BSE follow-up committee made a visit to the United Kingdom to learn about the implementation of BSE-related measures in the UK and the monitoring of them by the Commission. ${ }^{760}$ The Echelon committee visited London, Paris and Washington DC to meet people who were unable to attend the committee meetings but whose involvement in the committee's work nonetheless seemed advisable. ${ }^{761}$ The Improving Safety at Sea committee sent a delegation to Barcelona, where a meeting was arranged with the captain of the Prestige, Apostolos Mangouras, who was under house arrest pending his trial in Spain. A delegation from the FMD committee visited the regions in the UK and the Netherlands which were heavily affected by the foot-and-mouth disease outbreak. During these visits the committee delegations held talks with farmers, veterinarians and local authorities who were directly involved in the crisis. By doing so, the FMD committee's fact-finding visits served a third purpose, namely representing EU citizens. MEP Jonathan Evans (EPP-DE) expressed this aptly: "I [...] want to begin by thanking the committee for visiting Welshpool, Builth Wells and Sennybridge and meeting people within my constituency who said $[\ldots]$ that the European Parliament was the only

Committee on Legal Affairs and Human Rights. Alleged secret detentions in Council of Europe Member States (22.1.2006).

758 European Parliament (1997). BSE follow-up committee. Report on the European Commission's follow-up of the recommendations made by the committee of inquiry into BSE (A4-0362/97, 14.11.1997), p. 27.

759 Ibid.p. 27.

${ }^{760}$ Ibid. pp. 28-29.

${ }^{761}$ European Parliament (2001). Echelon committee. Report on the existence of a global system for the interception of private and commercial communications (ECHELON interception system) (Part 1, A5-0264/2001, 11.7.2001), p. 152. 
official body that came to listen to their views. That addresses, in my view, the issue of the relevance of the European Parliament". ${ }^{762}$

\subsection{Conclusion}

Since the right of inquiry was formally recognized in the EC Treaty in 1993, the Parliament has set up three temporary committees of inquiry, whereas in the same period twelve temporary special committees have been established. The more frequent use of the special committees raises several questions, such as: does the Parliament prefer to establish special committees over committees of inquiry? For what purpose are special committees established? And how do these special committees conduct their investigations?

\section{Legal status and legal aspects of temporary special committees}

In contrast with the right to set up committees of inquiry ex Article 226 TFEU, the establishment of special committees has no basis in the TFEU. The sole basis of special committees is Rule 184 of the Rules of Procedure of the European Parliament. Whereas the Interinstitutional Agreement on the right of inquiry provides for an additional layer of the general powers of the European Parliament, special committees do not have additional powers of investigation. Special committees thus have weaker powers but encounter fewer formal restrictions than committees of inquiry. Whereas committees of inquiry may only be established in cases of alleged contraventions or maladministration' in the EU context, special committees can be set up to investigate any object or subject.

The wide scope of the right to establish special committees explains why special committees have been established to conduct different kinds of investigations. Whereas committees of inquiry, due to their restricted scope, can only investigate alleged abuses in the EU sphere, special committees can be used to conduct all sorts of parliamentary investigations. The case studies have shown that the Parliament has established special committees both to hold executive actors to account and for 'non-accountability' purposes, such as preparing legislative decision-making and defining future budgetary priorities.

\section{Usefulness of temporary special committees}

Special committees have proved useful specifically because they provide a middle course in situations where setting up a committee of inquiry would be too heavy-handed, but where the Parliament nonetheless wants to establish a temporary committee to investigate a specific issue in-depth. Setting up special committees is furthermore useful if a committee of inquiry cannot be established because of the restricted scope of the right of inquiry. Another advantage is more political in nature. The use of the right of inquiry, the strongest control power of the Parliament, may be controversial within the Parliament and establishing a committee of inquiry therefore runs the risk that the political groups which initially reject the establishment of an inquiry committee frustrate its work when such a committee is nonetheless set up. The

${ }^{762} \mathrm{Cf}$. Plenary debate on the Foot and Mouth Disease committee's final report on 17 December 2002. 
Improving Safety at Sea case has shown that it can be useful to adopt a middle course in such cases by setting up a formally less-powerful special committee. Other advantages of the special committees are common to all temporary committees, meaning they also apply to temporary committees of inquiry. A first advantage of temporary committees is that they bring together MEPs from several standing committees with specific knowledge of the issues under investigation. Establishing a temporary committee prevents fights over which standing committee should deal with a given issue. Another important advantage is that issues are taken out of standing committees which are generally overloaded anyway. One could say that if an issue is not dealt with by a temporary committee, it is not possible to really deal with it in-depth. Additionally, there is an agenda-setting argument. Setting up a temporary committee guarantees that the spotlight is put on a specific issue and that the issue will appear not only on the committee agenda, but also on the plenary agenda and in all probability even on agendas outside the Parliament. The investigations into Echelon and CIA flights have proved to be consciousnessraising exercises in which special committees managed to bring alarming issues to light which were as good as unknown to the public before the Parliament put the spotlight on them.

No evidence has been found indicating a general preference for setting up special committees over setting up committees of inquiry. It seems it is not an unwillingness to set up committees of inquiry, but rather the narrow scope of the right of inquiry, which accounts for the more frequent use of special committees. In particular, the fact that the establishment of a committee of inquiry requires the existence of 'alleged contraventions or maladministration in the implementation of Union law' has proven an obstacle for a more frequent use of the right of inquiry.

\section{Proceedings of temporary special committees}

The proceedings of the special committees examined here bear a strong resemblance to those of committees of inquiry. At the outset of the investigation, special committees elected their chair and vice-chair(s) and their rapporteur, who is responsible for the report. The special committees subsequently gathered information on the matter under investigation. To that end, like committees of inquiry, they organized hearings, collected written information, and they generally conducted fact-finding visits. Cooperation was on several occasions refused by executive actors. As for the inquiries, the close ties between the Parliament and the Commission ensured the cooperation of the latter with investigations by special committees. The picture is somewhat different for national authorities. In particular, a large number of national ministers declined to give information to the CIA flights committee. However, it is by all means reasonable to argue that Member State authorities were neither legally, nor morally, obliged to cooperate in the CIA flights case, as this case lay beyond the scope of the European Parliament's sphere of competence. The CIA flights issue mainly centred on the question of whether national administrations (even of non-EU Member States) had been involved in secret CIA activities on the territory of the European Union. This falls under the Common Foreign and Security Policy (CFSP), which is an intergovernmental 
policy area in which the Parliament only plays a marginal role and where national parliaments, not the European Parliament, are the more appropriate forum to hold 'their' respective national governments to account.

Like the committees of inquiry, the special committees also made serious endeavours to become acquainted with the matters under investigation. This indicates that special committees are also willing to substantiate their conclusions on the basis of a thorough study. The resemblance of parliamentary inquiries and investigations by special committees was particularly strong for the investigations of the Echelon committee and the CIA flights committee, which can therefore be typified as 'quasi-inquiries'. These investigations could not be conducted by committees of inquiry due to the fact that both cases concerned issues outside the first (Community) pillar of the European Union. It should be noted that the Treaty of Lisbon has extended the scope of the right of inquiry from Community issues to Union issues, thus including the former second and third pillars.

There are, however, also differences between inquiries and investigations by special committees. The committee of inquiry into the Community Transit system strictly adhered to the legal framework of the right of inquiry. The Transit committee accepted that inquiry committees were limited in power and that witnesses were no more than 'voluntary co-operators'. As a consequence, in order to avoid the embarrassment of a refusal, the Transit committee did not invite national ministers to appear before it. Such considerations to exert restraint obviously factored less for the other two committees of inquiry. Even though special committees have fewer formal powers than committees of inquiry, the special committees displayed no restraint when gathering evidence. The special committees into Echelon and - in particular - the CIA flights did not hesitate to invite high-level office holders, such as national ministers, EU Commissioners, the EU High Representative for the CFSP, and the secretary-general of the Council of Europe. It seems these special committees took a 'nothing-to-lose' approach. Furthermore, there is a striking difference between the ways committees of inquiry and special committees dealt with refusals to cooperate in the course of investigations. Whereas the refusal of the UK agricultural minister, Douglas Hogg, to appear before the BSE inquiry committee led to great indignation in the Parliament, the mass refusal of national ministers to cooperate with the Echelon special committee was accepted with hardly a word of protest. This is all the more striking when one considers that neither inquiry committees nor special committees have a right to summon national ministers. The Transit inquiry presents a similar example. The tobacco manufacturer Philip Morris Europe was reluctant to appear before the Transit committee. Whereas special committees generally accept refusals without protest, the Transit committee insisted on Philip Morris' cooperation. Note that Philip Morris is a private company, over which committees of inquiry have no formal powers.

\section{Special committees vs. committees of inquiry; difference in standing}

The different attitudes of committees of inquiry and special committees discussed above can be explained by their difference in standing. Committees of inquiry are set up on the basis of a Treaty provision, whereas special 
committees are a type of internal parliamentary working group. Hence, a parliamentary inquiry is a more serious procedure than an investigation conducted by a special committee. The right of inquiry is used less often than the procedure to establish a special committee. Both types of committee create a different atmosphere. Committees of inquiry create a serious, almost inquisitorial atmosphere in which an issue of public concern is to be clarified. Even in cases where formal powers are lacking, the Parliament seems to presuppose some sort of moral obligation on persons, Member States, EU institutions and other bodies to cooperate in the course of an inquiry. In order to enforce these claims of a moral obligation to cooperate, the Parliament tends to remind non-cooperative Member States and EU institutions - mostly wrongfully - of the duty of sincere cooperation ex Article 4 (3) EU Treaty. The work of special committees, by contrast, generally seems to be part of the 'daily business' of the European Parliament. These investigations have a more informal character. If a witness does attend, that is a bonus, and if someone decides not to accept an invitation, that is not considered a disgrace but part of the game. 


\section{INVESTIGATIONS BY STANDING COMMITTEES}

\subsection{Introduction}

The Parliament handles a lot of tasks and so divides them among parliamentary committees. The standing committees, of which there are currently 20, carry out the preparatory work for the plenary sittings. They play a pivotal role in the work of the European Parliament. In the words of Sir Julian Priestley, the standing committees are the "principal repositories of parliamentary expertise on areas within their competence and for this reason any compromise reached in committee is unlikely to be ditched in the full EP session except in exceptional circumstances". ${ }^{763}$

The standing committees assist the plenary not only with the Parliament's legislative task by submitting legislative reports, but they also play an important role in the scrutiny and control of the executive. The presence of individual Commissioners, members of the Council, directors of EU agencies, the President of the ECB, and both national and Union civil servants at meetings of standing committees has become routine. ${ }^{764}$

The previous chapters on temporary committees of inquiry (Chapter 2) and temporary special committees (Chapter 3) revealed that the Parliament regularly sets up temporary committees to conduct accountability investigations. ${ }^{765}$ This chapter analyzes the investigative role of the Parliament's standing committees. Executive actors appearing before standing committees are generally held to account by means of questions from committee members. However, rather than discussing the full array of methods standing committees use to hold executive actors to account, this chapter focuses solely on parliamentary investigations. The main questions which will be addressed are: do standing committees carry out investigations in order to hold the executive to account? And if so, what kind of accountability investigations do they conduct and how do these investigations differ from the accountability investigations carried out by temporary committees?

Firstly, Section 4.2 discusses the standing committees of the European Parliament in general. Section 4.3 subsequently describes the position of standing committees when gathering information from executive actors in the course of investigations. Section 4.4 zooms in on the four types of investigations conducted by standing committees: inquiry-type investigations (Section 4.4.1); investigations following petitions (Section 4.4.2); investigations in the course of the discharge procedure (Section 4.4.3); and investigations regarding the implementation of EU legislation (Section 4.4.4). Conclusions are drawn in Section 4.5.

\footnotetext{
${ }^{763}$ Priestley (2008), p. 3.

${ }^{764}$ Cf. Corbett/Jacobs/Shackleton (2011), pp. 314-315.

${ }_{765} \mathrm{Cf}$. Section 1.4 .3 on the difference between 'accountability investigations' and 'nonaccountability investigations'.
} 


\subsection{Standing committees of the European Parliament}

In its current and seventh term (2009-2014), the European Parliament has 20 standing committees. The size, responsibilities ${ }^{766}$ and number of standing committees is generally decided during the July session of a newly elected Parliament, and again, albeit with limited changes, at the half-way point of the parliamentary term (after two-and-a-half years).

\subsubsection{Sectoral and functional committees}

The 22 standing committees (including two sub-committees) of the European Parliament are listed below (see Table 1).

\begin{tabular}{|c|c|c|c|}
\hline Committee & Acronym & Sectoral & Functional \\
\hline Foreign Affairs & AFET & $\mathrm{V}$ & \\
\hline - Human Rights ${ }^{767}$ & DROI & $\mathrm{V}$ & \\
\hline - Security and Defence ${ }^{768}$ & SEDE & $\mathrm{V}$ & \\
\hline Development & DEVE & $\mathrm{V}$ & \\
\hline International Trade & INTA & $\mathrm{V}$ & \\
\hline Budgets & BUDG & & $\mathrm{V}$ \\
\hline Budgetary Control & CONT & & $\mathrm{V}$ \\
\hline Economic and Monetary Affairs & $\mathrm{ECON}$ & $\mathrm{V}$ & \\
\hline Employment and Social Affairs & EMPL & $\mathrm{V}$ & \\
\hline $\begin{array}{l}\text { Environment, Public Health and Food } \\
\text { Safety }\end{array}$ & ENVI & $\mathrm{V}$ & \\
\hline Industry, Research and Energy & ITRE & $\mathrm{V}$ & \\
\hline $\begin{array}{l}\text { Internal Market and Consumer } \\
\text { Protection }\end{array}$ & IMCO & $\mathrm{V}$ & \\
\hline Transport and Tourism & TRAN & $\mathrm{V}$ & \\
\hline Regional Development & REGI & $\mathrm{V}$ & \\
\hline Agriculture and Rural Development & AGRI & $\mathrm{V}$ & \\
\hline Fisheries & $\mathrm{PECH}$ & $\mathrm{V}$ & \\
\hline Culture and Education & CULT & $\mathrm{V}$ & \\
\hline Legal Affairs & JURI & & $\mathrm{V}$ \\
\hline Civil Liberties, Justice and Home Affairs & LIBE & $\mathrm{V}$ & \\
\hline Constitutional Affairs & $\mathrm{AFCO}$ & & $\mathrm{V}$ \\
\hline Women's Rights and Gender Equality & FEMM & $\mathrm{V}$ & \\
\hline Petitions & PETI & & $\mathrm{V}$ \\
\hline
\end{tabular}

Figure 4.1 Standing committees of the European Parliament

\footnotetext{
766 The responsibilities of the individual standing committees are laid down in Annex VII of the Rules of Procedure. On the basis of these terms of reference it is decided which committee deals with a given issue.

767 The Committee on Human Rights (DROI) is a sub-committee of the Committee on Foreign Affairs (AFET).

768 The Committee on Security and Defence (SEDE) is a sub-committee of the Committee on Foreign Affairs (AFET).
} 
Standing committees deal with issues ranging from fisheries to constitutional affairs, and women's rights to agriculture. The activities of these standing committees are almost as multifaceted as the issues they deal with. Most committees (17 including the two sub-committees) are responsible for one or more specific policy areas and all of their activities relate to these specific policy area(s). These committees, the 'sectoral committees', are involved in some way whenever their policy area is touched on, irrespective of whether budgetary activities, scrutiny activities, or the preparation of legislative acts. Another category of committee composes those which concentrate on a specific function rather than on a specific policy area. This category could be called 'functional committees'. The Parliament currently has five such committees. The committee on Budgets and the committee on Budgetary Control are responsible for the exercise of the Parliament's budgetary function. The committee on Legal Affairs fulfils the function of Parliament's legal adviser and the committee on Constitutional Affairs is responsible for institutional aspects regarding the European Union. The committee on Petitions, lastly, deals with petitions from EU citizens.

Whereas sectoral committees are involved whenever their policy area is touched on, functional committees are involved whenever their function is required. It follows that several committees can be involved in one dossier simultaneously. Take for example the preparation of the EU budget for the European Regional Development Fund.769 The committee on Budgets will be primarily responsible for this dossier, but the committee on Regional Development can (and, as a rule, will) send its observations to the committee on Budgets in the form of an 'opinion' ( $c f$. Rule 49 Rules of Procedure of the European Parliament). Another example is the handling of petitions concerning gender issues, where the committee on Petitions will be primarily responsible, but where the committee on Women's Rights and Gender Equality may send an opinion to the committee on Petitions.

A relevant question in the context of this book is which of the standing committees may conduct parliamentary investigations. Whereas it goes without saying that sectoral committees may scrutinize executive action in the field of their specific policy area(s), it is not self-evident whether functional committees may engage in accountability activities. This depends on the specific function a committee fulfils. For the committee on Budgetary Control and the committee on Petitions it can be said that scrutinizing executive action is their raison d'etre ${ }^{770}$ - the function of the former being to exercise control over the implementation of the EU budget and of the latter the examination of petitions filed to the Parliament. It can thus be expected that they conduct

\footnotetext{
769 The European Regional Development Fund, which is managed by the European Commission, aims to strengthen economic and social cohesion in the European Union by correcting imbalances between its regions. $\mathrm{C}$. http://ec.europa.eu/regional_policy/thefunds/regional/index_en.cfm.

770 The parliamentary investigations conducted by these standing committees will be discussed in Section 4.4.2 (Committee on Petitions) and Section 4.4.3 (Committee on Budgetary Control).
} 
accountability investigations. ${ }^{771}$ The functions of the three other functional committees (Budgets, Legal Affairs, and Constitutional Affairs) are, however, not related to the scrutiny of executive action. It is therefore not surprising that these committees do not conduct accountability investigations.

\subsubsection{Committee members}

The memberships of standing committees are allocated following a proposal from the Conference of Presidents. ${ }^{772}$ The political groups, represented by their chairpersons in the Conference of Presidents, determine the committee assignments in rough proportion to their respective seats in plenary. The groups also endeavour to maintain a proportionate national balance on the committees. ${ }^{773}$ Most MEPs serve as a full member on one committee and as a substitute member on another. Substitute members have full speaking rights during committee meetings and if full members are absent (which generally is the case) they also have full voting rights. ${ }^{774}$ Substitutes may serve as rapporteurs or draftspersons. In 2012, the size of committees ranged from 25 MEPs (committee on Fisheries and committee on Legal Affairs) to 64 MEPs (committee on Environment, Public Health and Food Safety) and 76 MEPs (committee on Foreign Affairs), excluding substitute members.

\subsubsection{Committee bureaux}

All committees have a bureau, which consists of a committee chair and vicechairs (generally four). The chair presides over the committee meetings, speaks for it in plenary sessions at a time of sensitive votes or decisions, and represents the committee at the meeting of committee chairs. The chair can further have a powerful role in shaping the agenda of the committee and in acting as its representative outside Parliament. ${ }^{775}$ Formally speaking, the chair and vice-chairs are elected at the constituent meeting of a committee. ${ }^{776}$ In practice, however, these positions are - prior to the constituent committee meetings - shared out by agreement among political groups based on the size of each group. Groups choose posts in accordance with the proportional d'Hondt system, in group-size order. In 2004, for example, the EPP-ED group had the right to the first, third, fifth, seventh, ninth, twelfth, seventeenth, nineteenth and twenty-first choices, the Socialists to the second, fourth, eighth, tenth, sixteenth, twentieth and twenty-third choices, the Liberals to the sixth, thirteenth and twenty-second choices, the Greens to the eleventh choice, the GUE group to the fifteenth choice, Independence and Democracy to the eighteenth choice and UEN to the twenty-fourth choice. ${ }^{777}$

\footnotetext{
771 Section 4.4.2 examines the investigative role of the Committee on Petitions and Section 4.4.3 addresses the investigative role of the Committee on Budgetary Control.

772 Cf. Rule 183 Rules of Procedure of the European Parliament.

773 Cf. Judge/Earnshaw (2008), p. 172.

${ }_{774}$ Cf. Rule 187 (1) Rules of Procedure.

775 Cf. Corbett/Jacobs/Shackleton (2011), p. 147.

776 Cf. Rule 191 (1) Rules of Procedure.

777 Cf. Corbett/Jacobs/Shackleton (2011), pp. 147-148; Judge/Earnshaw (2008), p. 173.
} 


\subsubsection{Rapporteurs, draftspersons and shadow rapporteurs}

For every report or opinion a committee intends to draw up, it nominates a rapporteur (if the committee is primarily responsible) or a draftsperson (if it has to draw up an opinion for another committee). It is the rapporteur's job to prepare for initial discussions in the committee. Subsequently he or she presents a draft text to the committee which, if necessary, is amended to take account of committee's observations or new developments. After the report is adopted in committee, the rapporteur presents it in plenary. For legislative reports, the rapporteur must also follow developments after the first reading in the Parliament and prepare a recommendation for the second reading. ${ }^{778}$

Draftspersons of opinions are appointed by the committee asked for an opinion. Before they draft their opinion, draftspersons prepare an initial discussion in committee. In the case of legislative documents, the opinion consists of draft amendments to the text referred to the committee. In the case of nonlegislative texts, the opinion consists of suggestions for the motion for a resolution submitted by the committee responsible. All adopted opinions are annexed to the report of the committee responsible.

Draftspersons and - especially - rapporteurs can be highly influential. In order to prevent conflicts between political groups as to which group may assign a rapporteur or draftspersons, a special system has been created. Each political group receives a number of points corresponding to its size. With these points the political groups can bid on a report. The highest bidding group may assign a rapporteur or draftsperson. ${ }^{779}$ This system ensures that smaller groups may also sometimes assign a rapporteur or draftsperson. Ken Collins, a former MEP, has described the system as "a combination of a kind of auction and a kind of elaborate game of poker because the technique of the group spokesman is to spend the minimum points for his or her group, and to get the maximum number of reports, which means you have to bid up for things that you do not actually want". 780

Each political group may also designate a shadow rapporteur to follow the progress of a specific report and to find compromises within the committee on behalf of the group. ${ }^{781}$

\subsubsection{Group coordinators}

Each political group may designate one of its members as coordinator within a standing committee. ${ }^{782}$ These so-called group coordinators play an important role in the work of standing committees. Together with the committee's bureau, the group coordinators facilitate the working of the committee by arranging the agenda and by discussing forthcoming votes, amendments and broader political problems before they are considered in full committee. ${ }^{783}$ An

\footnotetext{
${ }_{778} C f$. Rule 63 (3) Rules of Procedure; and: Corbett/Jacobs/Shackleton (2011), p. 158.

$779 \mathrm{Cf}$. Corbett/Jacobs/Shackleton (2011), pp. 158-159; Judge/Earnshaw (2008), pp. 177-178.

780 Wurzel (1999), p. 12.

${ }^{781} \mathrm{Cf}$. Rule 192 (3) Rules of Procedure.

782 Cf. Rule 192 (1) Rules of Procedure.

783 Cf. Rule 192 (2) Rules of Procedure; Corbett/Jacobs/Shackleton (2011), p. 151; Judge/Earnshaw (2008), pp. 176-177.
} 
important task of group coordinators is to share out rapporteurships (following the system described above). Once a rapporteurship has been assigned to a specific political group, the coordinator of that group generally decides which member of the group becomes rapporteur. The group coordinator also decides which substitute member may vote in the absence of a full member of the group. ${ }^{784}$

As Judge and Earnshaw describe, the group coordinators perform many of the functions associated with 'party whips' in other legislatures: convening premeetings to formulate the group's position on forthcoming votes in the full committee, working out a schedule of speakers, ensuring attendance at important votes, and communicating the work of the group in the standing committee to the political group outside the committee. ${ }^{785}$

\subsubsection{Committee staff}

Each standing committee has a full-time staff consisting of a head of unit, between four and ten administrators, one or two committee assistants and a number of secretaries. The committee staff assists rapporteurs with background research and has an important role in briefing members on the past activities and positions adopted within the committee. ${ }^{786}$

In addition, other officials attend committee meetings. The Legal Service of the Parliament advises committees on legal questions, the Directorate-General for Information is represented and researchers from the Policy departments working alongside the committee secretariats also follow the meetings. Political groups also designate staff (up to three persons for a big group in a large committee) to follow an individual committee. Finally, members have their own personal assistants who can attend the committee meetings. ${ }^{787}$

Compared to the US Congress this looks rather modest, but compared to national parliaments in Europe, the European Parliament has one of the largest staffs. ${ }^{788}$ None of the persons interviewed in the course of this research observed that committees of the European Parliament (both temporary and standing) were 'understaffed'.

\subsubsection{Own-initiative reports}

In addition to legislative or other proposals referred to them, parliamentary committees may examine specific issues on their own initiative. In such cases, committees have to ask the Conference of Presidents for permission to prepare an 'own-initiative report'. Typical reasons for rejecting requests for approval include that the subject matter falls within the remit of another committee, that the issue has been recently handled by the Parliament, or that the plenary agenda is overloaded. ${ }^{789}$ Annex XVIII of the Rules of Procedure of the European Parliament lists five types of own-initiative reports:

\footnotetext{
${ }^{784} \mathrm{Cf}$. Corbett/Jacobs/Shackleton (2011), p. 151; Judge/Earnshaw (2008), p. 176.

${ }^{785}$ Judge/Earnshaw (2008), p. 176.

${ }^{786} \mathrm{Cf}$. Corbett/Jacobs/Shackleton (2011), pp. 151-152.

787 Ibid. p. 152.

788 Cf. Shapiro (1998), pp. 199-207.

789 Cf. Corbett/Jacobs/Shackleton (2011), p. 155.
} 
(a) legislative own-initiative reports, drawn up on the basis of Article 225 TFEU;

(b) strategic reports, drawn up on the basis of non-legislative strategic and priority initiatives included in the Commission's annual legislative and work programme;

(c) non-legislative own-initiative reports, not drawn up on the basis of a document of another institution or body of the European Union;

(d) annual activity and monitoring reports as listed in Annex 1 of Annex XVIII of the Rules of Procedure;

(e) implementation reports on the transposition of EU legislation into national law and the implementation and enforcement thereof in Member States.

To avoid an overfull plenary agenda, the Rules of Procedure of the European Parliament provide for a ceiling of six own-initiative reports which may be drafted simultaneously by one committee, and committees may not adopt reports within three months of authorization. Legislative own-initiative reports (category a) are not subject to the ceiling of six reports. Conversely, committees may only draft one implementation report (category e) per year. ${ }^{790}$

\subsection{Gathering of information: legal procedures and informal practices}

The gathering of information is an "essential prerequisite" in the process of holding executive actors to account. ${ }^{791}$ A thorough examination and assessment of executive action requires the Parliament to have relevant information at its disposal. It is exactly for this reason that temporary committees of inquiry have additional powers for the gathering of evidence compared to other committees of the European Parliament. The standing committees and the special committees rely on the general array of powers of the European Parliament and its members. But what exactly are these powers? And which informal practices have developed over time for the gathering of information from executive actors? This section addresses these questions with regard to the main executive actors on the European level: the European Commission, the European Council, the Council, EU agencies, and the European Central Bank.

\subsubsection{European Commission}

The European Commission is generally seen as the "core executive" of the European Union. ${ }^{792}$ The relationship between the Parliament and the Commission is mainly governed by the TFEU and the so-called 'Framework Agreement'793, an interinstitutional agreement concluded between the Parliament and the Commission.

\footnotetext{
$790 \mathrm{Cf}$. Article 1 (2) Annex XVIII of the Rules of Procedure of the European Parliament.

791 Curtin (2009), p. 256.

792 See for example: Hix (2005), p. 32.

793 Framework Agreement on relations between the European Parliament and the European Commission (OJ L 304, 20.11.2010, pp. 47-62).
} 
Article 230 TFEU puts the Commission under an obligation to answer questions put to it 'by the European Parliament or its Members'. By posing questions to the Commission, the Parliament can obtain specific information from the Commission or the Commission can be asked for its opinion on specific issues. Parliamentary questions can be tabled in three ways. Firstly, any MEP may put questions to the Commission for a written answer. ${ }^{794}$ Secondly, any MEP may put questions to the Commission during question time. Question time with the Commission is held at each part-session of the Parliament. Questions which cannot be answered orally within the ninety minute period are answered in writing. ${ }^{795}$ Thirdly, questions for oral answer with debate may be tabled by a parliamentary committee, a political group, or at least forty MEPs.796 The Framework Agreement adds to these three procedures a periodical 'Question Hour' with the President of the Commission, comprising of two parts: the first with political group leaders conducted on an entirely spontaneous basis, and the second devoted to a policy topic agreed upon in advance but without prepared questions. ${ }^{797}$ The Framework Agreement also provides for the introduction of a 'Question Hour' with members of the Commission, (including the Vice-President for External Relations/High Representative of the Union for Foreign Affairs), with the aim of reforming the existing question time discussed above. In addition to these procedures, some standing committees have introduced question time to the Commission as regular events in their committee. The Commission generally delegates a specialized civil servant - rather than a Commissioner - to these events. This form of question time in committee is more informal and provides a greater opportunity for follow-up questions than its plenary equivalent. ${ }^{798}$

In addition to debates following parliamentary questions, the Parliament can discuss specific issues with the Commission following statements made by the Commission. The Commission is expected to explain its actions before the Parliament on a regular basis and to present its major policy initiatives to the Parliament before they are made known to the press. ${ }^{799}$ Statements made by the Commission are generally followed by a debate in plenary and the Parliament may conclude the debate with a resolution. Debates with the Commission take place both in plenary and in committee. Debates with individual members (including the Vice President/High Representative) and civil servants from the Commission at meetings of standing committees have become a routine event. ${ }^{800}$ The Treaties do not contain a general legal obligation for the Commission to appear before the Parliament if the Parliament so requests. However, the Framework Agreement stipulates that the Commission shall give priority to its presence, if requested, at the plenary sittings or meetings of parliamentary committees, over other competing events

\footnotetext{
${ }^{794}$ Rule 117 Rules of Procedure of the European Parliament.

795 Rule 116 Rules of Procedure of the European Parliament.

796 Rule 115 Rules of Procedure of the European Parliament.

797 Article 46 of the Framework Agreement on relations between the European Parliament and the European Commission (OJ L 304, 20.11.2010, pp. 47-62).

798 Cf. Corbett/Jacobs/Shackleton (2011), p. 317.

799 Ibid. p. 314.

800 Ibid. p. 315.
} 
or invitations. ${ }^{801}$ The Framework Agreement further stipulates that the Commission shall ensure that, as a general rule, Members of the Commission are present at plenary sittings for agenda items falling under their responsibility, whenever Parliament so requests'. ${ }^{802}$

Moreover, the Parliament receives information from the Commission through reporting obligations and practices. Some of these reporting mechanisms are provided for in the Treaties ${ }^{803}$ and others have developed as a practice over time. Under Article 318 TFEU, the Commission must 'submit annually to the Council and the European Parliament the accounts of the preceding financial year relating to the implementation of the budget'. Together with the annual report of the Court of Auditors and its 'statement of assurance', the accounts submitted by the Commission form the focus of the Parliament's annual discharge examination. Article 319 (2) TFEU stipulates that the Commission shall submit any necessary information to the Parliament at the latter's request in the course of the discharge procedure. ${ }^{804}$ Another well-known example of a reporting obligation enshrined in the Treaties is Article 249 (2) TFEU, which obliges the Commission to publish annually a general report on the activities of the European Union. Some other reporting obligations are laid down in Article 25 TFEU (reports every three years on the application of the citizenship provisions of the Treaty), Article 159 TFEU and 161 TFEU (annual report on social policy and social developments), Article 175 TFEU (reports every three years on economic and social cohesion), Article 190 TFEU (annual report on research and technological developments activities), and, finally, Article 5 of the Protocol on the application of the principles of subsidiarity and proportionality (annual report on the application of these principles). The Commission further produces regularly follow-up reports on how specific pieces of legislation are working in practice. Such follow-up reports can be called for in legislation and/or they can be sent to the Parliament on the latter's request. Reporting mechanisms are an indispensable tool for the Parliament in its quest to hold the Commission to account. In the words of Corbett et al. "these reports provide formal, public, quotable information, the essential raw material for adequate control and scrutiny". ${ }^{805}$

\subsubsection{European Council}

The European Council - since Lisbon an official EU institution - consists of the Heads of State or Government of the EU Member States, together with its

\footnotetext{
801 Article 45 of the Framework Agreement on relations between the European Parliament and the European Commission (OJ L 304, 20.11.2010, pp. 47-62).

802 Ibid.

803 The best-known example of such a reporting obligation enshrined in the Treaties is Article 249 (2) TFEU, which stipulates that the Commission shall publish annually, not later than one month before the opening of the session of the European Parliament, a general report on the activities of the Union. Another example can be found in Article 319 (3) TFEU, which stipulates that the Commission, at the request of the European Parliament, shall report on the measures taken in the light of Parliament's observations regarding the giving of discharge.

${ }^{804}$ Section 4.4.3 discusses the discharge procedure.

${ }^{805}$ Corbett/Jacobs/Shackleton (2011), p. 318.
} 
President and the President of the Commission. ${ }^{806}$ Article 15 (1) TEU underlines the steering role of the European Council: 'the European Council shall provide the Union with the necessary impetus for its development and shall define the general political directions and priorities thereof. It shall not exercise legislative functions'. The constitutional ties between the European Council and the Parliament are substantially less close than the ties between the Commission and the Parliament. This finds expression inter alia in the limited information arrangements between the European Council and the Parliament. A reporting practice which has developed over time is that the European Council presents an annual written report to the Parliament on the progress achieved by the European Union. 807

The Treaty of Lisbon called the office of European Council President into existence and assigned this office-holder inter alia with the task of representing the European Council before the Parliament. This task is laid down in Article 15 (6), sub d, TEU, which stipulates that the President of the European Council shall present a report to the European Parliament after each of the meetings of the European Council. This means in practice that the President of the European Council appears in the Parliament after European Council summits to inform the Parliament on the outcomes of these summits. Rule 117 of the Rules of Procedure of the European Parliament further stipulates that any MEP may address written questions to the President of the European Council. It will be interesting to watch how the informal contacts between the Parliament and the European Council President develop in the future.

\subsubsection{Council of the European Union}

The Council of the European Union ('the Council') consists of representatives of each Member State at ministerial level, who may commit their government and cast its vote. 808 The presidency of the Council rotates between Member States every six months.

The Council informs the Parliament regularly of its activities. Information is given on the basis of informal mechanisms that have been established over time, rather than as a result of legally binding reporting obligations. Even though this has not been formalized in the Treaties, conventions have grown in practice whereby the Council replies to written and oral parliamentary questions and whereby it engages in debates with the Parliament.809 Represented by the Presidency or by senior Council officials, the Council regularly attends both plenary and committee meetings of the European Parliament. Jack Cunningham, the then UK agriculture minister, pointed out that in the first month of the 1998 UK Presidency he had appeared more times before EP committees than he had before House of Commons committees during his whole term of office as minister. ${ }^{810}$ Although these conventions do not create legal obligations as such, they do impose constraints on the Council.

\footnotetext{
806 The High Representative of the Union for Foreign Affairs and Security Policy further takes part in its work. $C f$. Article $15(2)$ of the Treaty on the European Union.

${ }^{807}$ Cf. Corbett/Jacobs/Shackleton (2011), p. 319.

${ }^{808} \mathrm{Cf}$. Article 16 (2) of the Treaty on the European Union.

809 Chalmers (2006), p. 118; Driessen (2007), pp. 88-89.

${ }^{810} C f$. Corbett/Jacobs/Shackleton (2011), p. 315.
} 
Interinstitutional conventions differ from mere practice in that there is an element of perceived obligation. On the other hand, they differ from customary law in that there is no legal, but rather a political obligation. 811

A right to pose questions to the Council and the High Representative of the Union for Foreign Affairs and Security Policy concerning the common foreign and security policy is provided for in Article 36 TEU. In contrast with questions to the Commission under Article 230 TFEU, this provision does not contain an explicit obligation for the Council or the High Representative to respond to these questions.

The Council has several reporting obligations. Under Article 121 (2) TFEU, the Council shall inform the Parliament of any recommendation on broad guidelines for economic policies in the Member States, and the President of the Council and the Commission must report on 'multilateral surveillance' of Member State economic policies, while the President of the Council may be invited to appear before the competent standing committee of the European Parliament if any recommendation has been made public (Article 121 (5) TFEU). Under Article 126 TFEU, the President of the Council must further inform the Parliament of any measure taken against a Member State as part of the excessive deficit procedure, and under Article 300 TFEU, the Council must inform the Parliament of any decision suspending an international agreement or taking a position in relation to an international agreement that has legal effects.

\subsubsection{European Central Bank}

The European Central Bank (hereafter: ECB) is the central bank for Europe's single currency, the euro. The ECB's main official task is to maintain price stability in the euro area. To this end, the ECB is equipped with executive powers, such as the exclusive right to authorize the issue of euro banknotes within the euro zone (Art. 128 TFEU). Article 282 (3) TFEU stipulates that the ECB 'shall be independent in the exercise of its powers and in the management of its finances. Union institutions, bodies, offices and agencies and the governments of the Member States shall respect that independence'. The independence of the ECB, however, by no means implies that it cannot be held to account for its actions. The ECB website puts this as follows: "it is a founding principle of democratic societies that any independent institution bestowed with a public function should be accountable to citizens and their elected representatives. Accountability is therefore an important counterpart of central bank independence”. ${ }^{812}$

The European Central Bank informs the European Parliament regularly about its activities. An important event is the annual plenary debate with the ECB President on the annual report on the activities of the European System of Central Banks (ESCB) and on the monetary policy of both the previous and current year (Article 284 (3) TFEU). Moreover, the ECB President reports every three months on the ECB's monetary policy and its other tasks during

\footnotetext{
${ }^{811} C f$. Driessen (2007), p. 37.

${ }^{812} \mathrm{Cf}$. Official website of the European Central Bank:

http://www.ecb.europa.eu/ecb/orga/accountability/html/index.en.html.
} 
hearings before the Parliament's committee on Economic and Monetary Affairs. Although not legally obliged to do so, Wim Duisenberg, the first ECB President, agreed to this arrangement and his successors, Jean-Claude Trichet and Mario Draghi have continued the practice. Corbett et al. point out that this has become the most important mechanism for scrutinizing the ECB's actions. ${ }^{813}$ Other members of the ECB's Executive Board also appear before the European Parliament. In addition, informal discussions take place between ECB representatives and MEPs on ECB policies and a convention has grown whereby the ECB replies to written questions put to it by MEPs. ${ }^{814}$

Jabko observes that this willingness to comply voluntarily with informal arrangements with the European Parliament stems from the ECB's desire to gain more democratic legitimacy. ${ }^{815}$ According to Jabko, the informal arrangements with the Parliament actually served as an instrument for the ECB "to increase its legitimacy and defend its independence". ${ }^{816}$

\subsubsection{EU agencies}

The recent decades have witnessed an explosion of 'new' executive actors in the European Union: the EU agencies. Their increasing number and powers including powers to adopt decisions that are legally binding on third parties require appropriate accountability mechanisms to keep them in check. ${ }^{817}$

As there is no general arrangement governing contacts between the Parliament and EU agencies, the picture of both legal and informal information arrangements between the Parliament and EU agencies can be aptly described as "patchy". ${ }^{118}$ In order to keep an eye on agencies, the Parliament has assigned specific (sectoral ${ }^{819}$ ) standing committees to specific agencies. The committee on Environment, Public Health and Food Safety, for example, is responsible for monitoring the European Environment Agency (EEA), the European Chemical Agency (ECHA), the European Medicines Agency (EMA), the European Centre for Disease Prevention and Control (ECDC), and the European Food Safety Authority (EFSA). ${ }^{820}$ Standing committees, for their part, assign individual MEPs as 'liaison MEPs' to specific agencies. The MEPs scrutinize the agency and, in general, act as a contact person between the Parliament and the agency.

In the course of the discharge procedure, agencies subject to discharge are - at the Parliament's request - under an obligation to submit any necessary information to the Parliament and must report on the measures taken

${ }^{813}$ Corbett/Jacobs/Shackleton (2011), p. 315.

${ }^{814} \mathrm{Cf}$. Official website of the European Central Bank:

http://www.ecb.europa.eu/ecb/orga/accountability/html/index.en.html.

815 Jabko (2003), p. 719.

816 Ibid. p. 721.

817 For a description of the 'explosion of agencies' in the European Union, $c f$. Curtin (2009), pp. 146-150. For specific reading on the accountability of EU agencies, $c f$. Busuioc (2010a).

818 Busuioc (2010a), pp. 98 and further.

${ }^{819}$ Cf. Section 4.2.1.

$820 C f$. ANNEX VII Rules of procedure of the European Parliament on the powers and responsibilities of standing committees. 
following previous discharge decisions. ${ }^{821}$ Specific legal arrangements between the Parliament and EU agencies can be found in the basic regulations of individual agencies. Whereas the Parliament has managed to agree legal reporting obligations with most $\mathrm{EU}$ agencies, it plays a low-key role in scrutinizing the so-called 'self-funded agencies' (e.g. the CPVO and OHIM), which are not subject to discharge by the Parliament. 822

Practice shows that where formal powers are lacking, informal arrangements have as a rule been established in order to fill the gap. One of many examples of such informal arrangements is the convention whereby the committee on Environment, Public Health and Food Safety holds annual hearings with the European Medicines Agency (EMA), despite the fact that the EMA is under no legal obligation to attend these hearings. It has not always been the Parliament which urged such informal arrangements with agencies. Busuioc has pointed out that the agencies themselves have pressed for closer contacts. In a similar way to that described above for the ECB, this can be explained by the agencies' desire to gain more democratic legitimacy. In the words of Busuioc: "given that these bodies have often come under attack for their independence and insulation from political accountability, the set up of voluntary accountability links to the Parliament can help increase their legitimacy". ${ }^{823}$ Another, perhaps more important, reason for some agencies proving eager to establish and maintain close ties with the Parliament is the quest for budget support. Considering the Parliament's budgetary role, parliamentary support for the agencies' activities is of vital importance. It could be assumed that the Parliament is less tempted to cut the budgets of cooperative agencies than of uncooperative agencies. ${ }^{824}$

\subsection{Accountability investigations by standing committees}

Standing committees play an important role in both preparing legislation and holding EU executive actors to account. Their investigative activities are multifaceted. Standing committees conduct investigations with the aim of holding executive actors to account ('accountability investigations') as well as for other purposes, such as preparing legislative decision-making ('nonaccountability investigations'). Non-accountability investigations form the lion's share of the investigative work carried out by the Parliament's standing committees. Standing committees regularly draw up own-initiative reports to put specific issues on the Commission's legislative agenda and, even more often, they scrutinize the legislative proposals which are put to the Parliament by the Commission. However, as this book concentrates exclusively on 'accountability investigations's25, this chapter addresses only those investigations aimed at holding executive actors to account. There are four types of accountability investigations conducted by standing committees:

\footnotetext{
821 Cf. Article 95 (3) and Article 96 (2) Commission Regulation No. 2343/2002 of 23 December 2002. Section 4.4.3 discusses the discharge procedure in more detail.

${ }^{822}$ Busuioc (2010a), pp. 98-100.

${ }^{823}$ Ibid. p. 111.

${ }^{824}$ Cf. Ibid. pp. 111-112.

${ }^{825} \mathrm{Cf}$. Section 1.4.3.
} 
- inquiry-type investigations;

- $\quad$ investigations following petitions;

- $\quad$ investigations in the course of the discharge procedure; and

- investigations regarding the implementation of EU legislation.

\subsubsection{Inquiry-type investigations}

It is important to ask whether standing committees, like temporary committees, also conduct inquiry-type investigations which aim to clarify responsiblity for specific past incidents. The answer to this question is affirmative, although the inquiry-type investigations conducted by standing committees are different to those carried out by temporary committees. The difference lies mainly in the scale of the respective investigations. Temporary committees generally consist of approximately 20 MEPs; they rely on the support of their own secretariat, and meetings are organized specifically for the sake of their investigations. Investigations by standing committees, however, are carried out by one rapporteur and, as a rule, some shadow-rapporteurs. Their work is carried out alongside the large volume of work which standing committees generally have. The rapporteur thus shares the secretariat of the standing committee with the other committee members and he or she does not have the financial facilities which temporary committees have. Furthermore, temporary committees generally attract a higher degree of media coverage.

The restrictions caused by the relatively small scale of standing committee investigations make the ability to establish temporary committees indispensable. Without the ability to set up temporary committees, the Parliament could not have conducted investigations into large-scale issues, such as the handling of the BSE crisis ${ }^{826}$ and the alleged CIA rendition flights ${ }^{827}$. Standing committees are simply not in the luxurious position of being able to carry out such large-scale investigations at the same time as their other tasks. Hence, as Shackleton summarized: "if an issue is not being dealt with by a temporary committee, it won't be possible to really deal with it indepth". ${ }^{828}$

An example of a small scale inquiry-type investigation conducted by a standing committee is the investigation into the management of the $\mathrm{H}_{1} \mathrm{~N}_{1}$ influenza cases in 2009-2010 in the European Union.

The management of the H1N1 influenza cases in 2009-2010 in the European Union $\mathrm{H}_{1} \mathrm{~N}_{1}$ is a subtype of the influenza A virus. In June 2009, the World Health Organization (WHO) declared the H1N1 outbreak - often called 'swine flu' or 'Mexican flu' - to be a pandemic. The virus spread worldwide and had caused about 17,000 deaths by the start of 2010 . In reaction to this pandemic, several EU Member States purchased large amounts of vaccines to prevent the spread of $\mathrm{H} 1 \mathrm{~N} 1$. In April 2010, more than $200 \mathrm{MEPs}$ filed a request to set up a special committee to investigate the response to the $\mathrm{H}_{1} \mathrm{~N} 1$ pandemic. In a letter to the President of the European Parliament, the Greens/EFA group in

\footnotetext{
${ }^{826}$ Cf. Section 2.5.2.

${ }^{827}$ Cf. Section 3.6.5.

${ }^{828}$ Interview with Michael Shackleton, 15 april 2010.
} 
the Parliament argued that Member States spent billions of Euros on anti$\mathrm{H} 1 \mathrm{~N} 1$ vaccines despite the fact that shortly after $\mathrm{H}_{1} \mathrm{~N} 1$ emerged, it was found to cause only mild illness. ${ }^{829}$ They went on to say that countries that did not purchase anti-H1N1 vaccines (such as Poland) registered significantly fewer victims than other countries of similar population size (e.g. France). The MEPs went on to point out that the vaccines were authorized through a fasttrack procedure based on very little safety data. A request to set up a special committee on this issue was refused for subsidiarity reasons on 20 May 2010 as the Conference of Presidents was of the opinion that it was not the European Parliament's task to scrutinize the reaction of EU Member States to the $\mathrm{H}_{1} \mathrm{~N} 1$ pandemic. However, in compensation for this refusal, the Conference of Presidents granted permission to the committee on the Environment, Public Health and Food Safety (ENVI committee) to produce an own-initiative report on the management of the $\mathrm{H}_{1} \mathrm{~N} 1$ Influenza outbreak. Michèle Rivasi (Greens/EFA) was appointed as rapporteur in July 2010. Her task was to concentrate on European issues rather than national issues. More particularly, the brief was to find answers to the following questions: Has the EU reacted in an appropriate, responsible and transparent manner to $\mathrm{H}_{1} \mathrm{~N}_{1}$ ? Has there been careful consideration of risks and benefits on the basis of available data on $\mathrm{H}_{1} \mathrm{~N} 1$ for the authorization of vaccines and anti-viral medication? Have there been deficiencies with regard to independence, excellence and transparency of decision-making? Secondly, the task was to find out what changes should be made to EU response planning, in particular with regard to ensuring independence, excellence and transparency of decision-making. On 5 October 2010 the ENVI committee organized a workshop to discuss these issues with representatives from the Commission, the (former) Swedish Council Presidency, the Belgian Council Presidency, the European Medicines Agency (EMA), and the European Centre for Disease Prevention and Control (ECDC). The workshop proved helpful for the Parliament, not only because it brought together relevant players regarding $\mathrm{H}_{1} \mathrm{~N}_{1}$, but also because it facilitated a debate between these stakeholders and the Parliament. Further evidence was gathered through meetings with the Commission, the Belgian Council Presidency, and with the two EU agencies involved: the European Centre for Disease Prevention (ECDC) and the European Medicines Agency (EMA). Moreover, documents were received from the French Senate and the Assemblée Nationale, which had launched inquiries into the handling of $\mathrm{H} 1 \mathrm{~N} 1$.

The report and the resolution on the management of the $\mathrm{H}_{1} \mathrm{~N}_{1}$ influenza in 2009-2010 in the European Union were adopted in committee on 25 January 2011 and in plenary on 8 March 2011. The rapporteur, Rivasi, commented that the report was "an important attempt to highlight the concerns that have been raised about the disproportionate response to the swine flu in Europe, as

${ }^{829} C f$. Letter of 21 April 2010 from MEP Rebecca Harms and MEP Daniel Cohn-Bendit, on behalf of the Greens/EFA Group, to the President of the European Parliament (PE $440.810 / \mathrm{CPG})$. 
well as the potential influence of pharmaceutical companies in response processes". ${ }^{830}$

The report criticizes the "disproportionate" response to the outbreak of the $\mathrm{H} 1 \mathrm{~N} 1$ virus in 2009-2010. ${ }^{83} \mathrm{H}_{1 \mathrm{~N}} 1$ had caused 2900 deaths in Europe by April 2010, which compares with 40,000 for seasonal flu in a moderate year. The moderate severity of $\mathrm{H}_{1} \mathrm{~N}_{1}$ influenza was officially recognized by the WHO as early as May 2009 by Margaret Chan, the Head of the World Health Organization (WHO) - which is to say one month prior to the WHO issuing a level-6 'pandemic' alert over H1N1. Member States and European institutions accepted this maximum-level alert, triggering costly measures in some Member States which were disproportionate to the actual - and known severity of $\mathrm{H}_{1} \mathrm{~N}_{1}$ influenza. The report suggests that the WHO should urgently revise its definition to include the severity of a disease in its definitions of the stages of a pandemic to allow for more appropriate responses. The report also called for better cooperation between Member States and more coordination of the European Centre for Disease Prevention and Control (ECDC) in the response to pandemics. ${ }^{832}$ According to the rapporteur, the analysis of the management of $\mathrm{H}_{1} \mathrm{~N} 1$ influenza in Europe highlighted an underlying problem: a lack of independent evaluation by national and/or European health authorities, and a resulting failure to adapt the public health measures, as best as possible and in real time, to the actual information available. The report suggests that ECDC should fully apply its competences as an independent agency to assess and communicate the severity of infection risk and be given adequate means for carrying out all its tasks. The rapporteur stressed that there is a need for studies on vaccines and antiviral medications that are independent of the pharmaceutical companies. ${ }^{833}$ The report concluded that greater transparency is needed in the evaluation of vaccines. Experts that advised the European public health authorities had conflicts of interests, which led to suspicions of undue influence. The report recommended that such conflicts of interest should thus be avoided. According to the rapporteur, at the very least, declarations of interests of those experts should be published. ${ }^{834}$

The $\mathrm{H}_{1} \mathrm{~N}_{1}$ investigation can be typified as a small-scale inquiry. The investigation was conducted by a rapporteur and six shadow-rapporteurs (from other political groups). On a somewhat smaller scale, these MEPs proceeded in the same way as a committee of inquiry would have. In order to evaluate the allegations of maladministration, they held hearings, organized a workshop, and collected documents. There are no indications that the (shadow) rapporteur(s) were hampered by the small scale of their investigation in terms of time, personnel (only one administrator was assigned to the

\footnotetext{
830 Cf. EP Press Release of 25 January 2011 ('Swine flu: lessons to learn from "disproportionate" EU response').

${ }^{831}$ European Parliament (2011). ENVI committee. Report on evaluation of the management of $\mathrm{H} 1 \mathrm{~N} 1$ influenza in 2009-2010 in the $\mathrm{EU}$ (A7-0035/2011, 9.2.2011), p. 7.

832 Ibid. p. 13.

839 Ibid. p. 14.

${ }^{834}$ Ibid. p. 14.
} 
dossier), and budget. However, it may be assumed that a temporary committee would have had attracted more media coverage for this sensitive public health issue. As discussed earlier in this book, the degree of publicity attracted by a specific investigation can be useful both in the course of an investigation and afterwards, with regard to the follow-up to recommendations formulated by the Parliament. 835

All in all, the $\mathrm{H}_{1} \mathrm{~N}_{1}$ investigation shows that an inquiry-type investigation conducted by a standing committee is a useful tool for the European Parliament, not only as a type of consolation prize if a temporary committee cannot be set up (for whatever reason), but also when the Parliament wants to investigate issues which, because of their small scale, are not suited for a fullblown temporary committee.

\subsubsection{Investigations following petitions}

The committee on Petitions deserves particular attention for the very reason that conducting accountability investigations is its raison d'être. The committee website underscores this by stating that the committee on Petitions "is an investigative committee, not a legislative committee". ${ }^{836}$ Its task is to investigate petitions from EU citizens and to resolve possible infringements of citizens' rights under the Treaty. By so doing, observes the chairwoman of the committee, Erminia Mazzoni, the committee on Petitions "plays a vital role in reconnecting with European citizens and in reinforcing the democratic legitimacy and accountability of the EU decision-making process". ${ }^{837}$

Article 227 TFEU gives any citizen of the European Union, acting individually or in association with others, the right to petition the European Parliament on a matter within the Union's fields of activity. The 2009 Annual Report of the committee on Petitions describes the right to petition as "a tool empowering citizens to bring before the Parliament their concerns with the impact of different EU policies and legislation on their everyday life". ${ }^{838}$ The committee on Petitions receives between 1500 and 2000 petitions every year. ${ }^{839}$ Petitions concerning a field of activity of the European Union will normally be declared admissible by the committee on Petitions. 'Environment' was in 2008, 2009 and 2010 the main field of concern for petitioners, followed by 'fundamental rights', 'justice' and 'internal market'. 840

The petitions process has various functions. Firstly, it offers EU citizens an easily accessible way to voice their concerns to the European Parliament and the Parliament can facilitate redress for petitioners in specific cases. Secondly, and more generally, it can make a positive contribution to better law-making,

\footnotetext{
${ }^{835} \mathrm{Cf}$. Section 2.7 .

${ }^{836} C f$. Website of the Committee on Petitions:

http://www.europarl.europa.eu/committees/en/PETI/home.html.

837 Ibid.

838 European Parliament (2010). PETI committee. Annual report of the Petitions committee 2009 (A7-0186/2010, 7.6.2010), p. 11.

839 The European Parliament received a number of 1655 petitions in 2010, 1924 in 2009, and 1849 in 2008.

${ }^{840}$ European Parliament (2010). PETI committee. Annual report of the Petitions committee 2009 (A7-0186/2010, 7.6.2010), p. 6.
} 
notably by identifying areas indicated by petitioners where existing EU law is weak or ineffective. Thirdly, the petitions process can make a contribution to the identification of instances in which Member States are not correctly applying Union law, which may lead to the initiation by the Commission of infringement procedures under Article 258 TFEU.

The Petitions committee decides for every admissible petition what type of action should be taken. Depending on the circumstances it may:

- $\quad$ ask the European Commission to conduct a preliminary investigation and provide information regarding compliance with relevant Community legislation or contact SOLVIT ${ }^{841}$;

- $\quad$ refer the petition to other parliamentary committees for information or further action (a committee might, for example, take account of a petition in its legislative activities);

- in some exceptional cases prepare and submit a full report to the Parliament to be voted upon in plenary; or conduct a fact-finding visit to the country or region concerned and issue a committee report containing its observations and recommendations;

- or take any other action considered appropriate to try to resolve an issue or deliver a suitable response to the petitioner. ${ }^{842}$

As of 2004, the Petitions committee has received a significant number of petitions from British, German and Irish citizens in relation to the collapse of the Equitable Life Assurance Society, a British life insurance company. The petitioners argued that UK regulators had failed to supervise adequately the ability of the Equitable Life Assurance Society to meet its regulatory financial requirements and that the actions and omissions of the past regulators were in breach of UK rules and the corresponding EU Directives. ${ }^{843}$ The Petitions committee called successfully for the establishment of a committee of inquiry on this issue. ${ }^{844}$ Interestingly, both the chairperson and the rapporteur of this inquiry committee (Mairead McGuinness (EPP-ED) and Diana Wallis (ALDE)), were members of the Petitions committee. An example of a case where the Petitions committee chose to investigate a specific issue itself is described below.

\footnotetext{
${ }^{841}$ SOLVIT is an online problem solving network in which EU Member States work together to solve without legal proceedings problems caused by the misapplication of Internal Market law by public authorities. The European Commission coordinates the network, which is operated by the Member States. $C f$. http://ec.europa.eu/solvit/site/about/index_en.htm.

${ }^{842} C f$. http://www.europarl.europa.eu/aboutparliament/en/00533cec74/Petitions.html.

843 European Parliament (2007). Equitable Life committee. Report on the crisis of the Equitable Life Assurance Society. Final Report (A6-0203/2007, 23.5.2007), p. 18.

${ }^{844}$ Section 2.5.3 discusses the inquiry into the collapse of the Equitable Life Assurance Society.
} 


\section{Natura 2000}

Many of the petitions to the Parliament concern environmental issues. ${ }^{845}$ The committee on Petitions receives a large amount of petitions regarding 'Natura 2000' every year. Natura 2000 is an EU-wide network of nature protection areas established under the Habitats Directive ${ }^{846}$. The main objective of Natura 2000 is to "contribute towards ensuring bio-diversity through the conservation of natural habitats and of wild fauna and flora in the European territory of the Member States". ${ }^{847}$ A large number of petitions signalling potential damage to Natura 2000 sites throughout the European Union induced the committee on Petitions to make a number of fact-finding visits to specific sites.

In 2005, the Petitions committee received several petitions concerning a decision by the Polish authorities to construct a dual-carriage roadway (the 'Via Baltica'), destined for heavy goods vehicles, through the Rospuda Valley, which is a Nature 2000 area in north-east Poland. Following discussions between the Petitions committee and the Commission on the issue, the Commission investigated the case and referred it to the European Court of Justice in March 2007, successfully requesting an interim measure to stop damage caused by the project. $^{848}$ The Petitions committee sent a delegation on a fact-finding mission to Poland in June 2007. The objective of the mission was to investigate with all interested parties the situation regarding the planned route for the 'Via Baltica' and the conformity of the existing plans with EU Directives, notably concerning the environmental impact of the project. ${ }^{849}$ The delegation concluded that the Polish authorities had breached the Habitats Directive. ${ }^{850}$ In October 2009, the Polish Government ultimately changed the initial route of the 'Via Baltica' in favour of an alternative route which did not affect the Natura 2000 areas. ${ }^{851}$

Other cases where the Petitions committee started investigations following petitions include, for example, the consequences of urbanization in Spain, and the lack of waste management in the European Union.

There is an overlap between the Parliament's activities concerning petitions under Article 227 TFEU and the work of the European Ombudsman under Article 228 TFEU, who can investigate complaints by the same set of persons as under Article 227 TFEU. An important difference, however, is that the Ombudsman can only investigate 'instances of maladministration' of authorities at the EU level, whereas Parliament may be petitioned on matters which come 'within the Union's fields of activity', and which thus include the activities of Member States.

\footnotetext{
${ }^{845}$ European Parliament (2010). PETI committee. Annual report of the Petitions committee 2009 (A7-0186/2010, 7.6.2010), pp. 14-16.

${ }^{846}$ Council Directive 92/43/EEC of 21 May 1992 on the conservation of natural habitats and of wild fauna and flora ('Habitats Directive', OJ L 206, 22.7.1992, pp. 7-50).

${ }^{847} \mathrm{Cf}$. Article 2 of the Habitats Directive.

${ }^{848}$ Cf. Case C-193/07, European Commission v Poland.

849 European Parliament (2007). PETI committee. Report on the Fact Finding Mission to Poland "Via Baltica" (Warszawa-Bialystok-Augustow) (PE 376.717, 16.7.2007), p. 17.

850 Ibid. p. 9.

${ }^{851} \mathrm{Cf}$. European Parliament (2010). ENVI committee. Report on the implementation of EU legislation aiming at the conservation of biodiversity (A7-0241/2010, 25.8.2010), p. 27.
} 
In the course of its work, the Petitions committee makes contacts with the Commission, the European Ombudsman, other parliamentary committees, European bodies, EU agencies, networks and Member States. As members of the Petitions committee regularly rely on the expertise of the Commission's services when investigating matters raised in petitions, the Petitions committee considers the Commission its 'natural partner'. ${ }^{852}$ Although the 2009 Annual Report of the Petitions committee states that the working relationship with the Commission has constantly improved, there remain issues which the Petitions committee deems problematic. A constant point of criticism appears to be the Commission not informing the Petitions committee about the progress of infringement proceedings directly linked to petitions. ${ }^{853}$ In its 2010 Annual Report, the Petitions committee observed that Member States remained reluctant to cooperate actively with the Petitions committee, and fail, for example, to attend meetings of the committee or to reply to letters sent to them. ${ }^{854}$

Through its annual reports, the Petitions committee regularly indicates its desire to further enhance its own independent investigatory facilities, notably through the reinforcement of its secretariat and its legal, linguistic and political expertise. ${ }^{855}$ In its 2008 Annual Report, the Petitions committee recommended the negotiation of a new interinstitutional agreement incorporating reinforced powers for committees of inquiry. ${ }^{856}$ It would not be a surprise if this recommendation was formulated by the members of the Petitions committee who had also been members of the committee of inquiry into the Equitable Life Assurance Society. ${ }^{857}$

\subsubsection{Investigations in the course of the discharge procedure}

Another functional committee ( $c f$. Section 4.2.1) of the European Parliament is the committee on Budgetary Control. The committee's main task is to scrutinize the implementation of the EU budget. Article 319 TFEU stipulates that the European Parliament, acting on a recommendation from the Council, shall give discharge to the Commission in respect of the implementation of the budget. By granting discharge, the Parliament formally states that it is

\footnotetext{
${ }_{852}$ European Parliament (2010). PETI committee. Annual report of the Petitions committee 2009 (A7-0186/2010, 7.6.2010), p. 20.

${ }^{853}$ European Parliament (2011). PETI committee. Annual report of the Petitions committee 2010 (A7-0232/2011, 17.6.2011), p. 7; European Parliament (2010). PETI committee. Annual report of the Petitions committee 2009 (A7-0186/2010, 7.6.2010), p. 20; European Parliament (2009). PETI committee. Annual report of the Petitions committee 2008 (A60232/2009, 3.4.2009), p. 15.

${ }^{854}$ European Parliament (2011). PETI committee. Annual report of the Petitions committee 2010 (A7-0232/2011, 17.6.2011), p. 3.

855 Cf. European Parliament (2010). PETI committee. Annual report of the Petitions committee 2009 (A7-0186/2010, 7.6.2010), p 10; European Parliament (2009). PETI committee. Annual report of the Petitions committee 2008 (A6-0232/2009, 3.4.2009), p. 17.

856 Cf. European Parliament (2009). PETI committee. Annual report of the Petitions committee 2008 (A6-0232/2009, 3.4.2009), p. 15.

857 The Equitable Life Committee formulated a similar recommendation, $c f$. European Parliament (2007). Equitable Life committee. Report on the crisis of the Equitable Life Assurance Society. Final Report (A6-0203/2007, 23.5.2007), p. 369.
} 
satisfied with the implementation of the budget over a specific financial year. The discharge procedure first and foremost concerns the Commission, which is responsible for implementing the EU Budget. However, it also concerns other EU Institutions (such as the Parliament, the Council, the Court of Auditors and the Court of Justice) and other bodies which spend EU money (such as EU agencies and the European Development Fund).

The Parliament's budgetary function is generally distinguished from its legislative and scrutiny functions. However, this distinction denies the fact that the discharge procedure is actually a textbook example of an accountability procedure through which executive actors are held to account for their implementation of the EU budget. The discharge procedure is therefore discussed in more detail hereafter.

\subsubsection{Timetable of the discharge procedure}

The discharge procedure for the budget of year $X$ is as follows. At the end of financial year $X$, which runs from January to December, institutions, bodies and agencies of the European Union must draw up their audited accounts for submission to the European Court of Auditors. The Court of Auditors is responsible for examining the legality, regularity and sound financial management of all revenue and expenditure. ${ }^{858}$ After the close of financial year $X$, the Court of Auditors lays down its findings over the financial year $X$ in Annual Reports. At the end of year $X+1$, by 15 November at the latest ${ }^{859}$, these reports are forwarded to the Council and the European Parliament for consideration under the annual discharge procedure (Article 319 TFEU). On the basis of the annual reports of the Court of Auditors, the committee on Budgetary Control subsequently investigates whether or not the Parliament should grant discharge for the budget of year $X$. To this end, the Commission and other institutions, agencies and bodies are invited to give statements before the committee on Budgetary Control and to answer questions regarding the implementation of the budget. In this context, the Commission is under an obligation to submit any necessary information to the Parliament at the latter's request. ${ }^{860}$ The committee on Budgetary Control finishes its work by submitting its report by 30 April of the year $X+2 .{ }^{861}$ This committee can give two types of recommendation to the plenary: either to grant discharge to the budget of year $X$ or to postpone this decision. The latter advice could be prompted by findings of irregularities of any nature or by the fact that the committee needs more time to submit solid advice to the plenary. The plenary shall subsequently decide before 15 May of year $X+2$ whether or not it grants discharge to the Commission for the implementation of the budget for year

\footnotetext{
858 Article 287 TFEU.

859 Article 153 (5) Council Regulation (EC, Euratom) No 1605/2002 of 25 June 2002 on the Financial Regulation applicable to the general budget of the European Communities (OJ L 248, 16.9.2002, pp. 1-48).

$860 \mathrm{Cf}$. Article 319 (2) TFEU.

${ }^{861} \mathrm{Cf}$. Article 2 (1) of the "Procedure for the consideration and adoption of decisions on the granting of discharge"; Annex VI to the Rules of Procedure of the European Parliament.
} 
$X .{ }^{862}$ If it decides to do so, the financial year $X$ can be closed. If it decides to postpone this decision, the Parliament has a further six months to consider whether to grant or refuse discharge for financial year $X$ and the Commission shall be informed of the reasons of the postponement. ${ }^{863}$ The six-month period between the postponement and the final vote is designed to put maximum pressure on the Commission (and other executive actors) to respond to the reasons for postponement. ${ }^{864}$

A financial year thus can be closed by granting discharge for that year. But what if the European Parliament refuses to grant discharge? Neither the Treaties, nor any legislation derived from the Treaties, provide an answer to this question. It goes without saying that a refusal to grant discharge does not place the Commission under a legal duty to resign, since that would offer a simple parliamentary majority the ability to sidestep the option of censuring the Commission by qualified majority vote in accordance with Article 234 TFEU. From a political perspective, however, things might be quite different. In 1977, the British Commissioner Tugendhat, who at the time was responsible for the budget, told the Parliament that a "refusal to grant discharge is a political sanction which would be extremely serious; the Commission thus censured would, I think, have to be replaced". 865 A refusal to grant discharge to the Commission indeed represents a major political reprimand. By refusing discharge, the Parliament publicly states that the Commission has failed in one of its central tasks: its management of the budget has either been irregular and/or uneconomical or has failed to respect the political objectives set when the budget was adopted. ${ }^{866}$

\subsubsection{Holding the executive to account through the discharge procedure}

The committee on Budgetary Control uses the discharge procedure to look into issues of budgetary implementation in detail. To that end, it examines documents, notably the annual reports of the Court of Auditors, and invites executive actors, such as Commissioners and directors of EU agencies, to account for budgetary issues. The committee on Budgetary Control finds itself in a strong position in the course of its activities. This can be explained by the fact that the ability to refuse to grant discharge represents a serious threat to executive actors. Other committees of the European Parliament lack such direct trump cards which can be used to ensure a cooperative attitude from the executive. Generally speaking, parliamentary committees, even committees of inquiry, are in a weak position to do anything about a refusal by an executive actor to disclose specific information to it. The committee on Budgetary Control, by contrast, can threaten to postpone, or even give a refusal, to grant

${ }^{862}$ Cf. Article 156 (1) Council Regulation (EC, Euratom) No 1605/2002 of 25 June 2002 on the Financial Regulation applicable to the general budget of the European Communities (OJ L 248, 16.9.2002, pp. 1-48).

${ }^{863}$ Cf. Article 156 (2) Council Regulation (EC, Euratom) No 1605/2002 of 25 June 2002 on the Financial Regulation applicable to the general budget of the European Communities (OJ L 248, 16.9.2002, pp. 1-48).

864 Corbett/Jacobs/Shackleton (2011), p. 290.

865 Ibid. p. 288.

${ }^{866}$ Ibid. pp. 287-288. 
discharge. Hence, in the words of Lenaerts and Verhoeven, discharge has become "an instrument to ensure a proper flow of information to the European Parliament". ${ }^{867}$

Practice shows that the committee on Budgetary Control has increasingly pressed its right to be fully informed on budgetary matters. It has been probing specific allegations of financial mismanagement, irregularity, fraud and corruption with ever-greater insistence. ${ }^{868}$ The ultimate outcome of this insistence was the crisis of 1999, when allegations regarding fraud, mismanagement and nepotism in the European Commission came to light. The Commission had been reluctant to provide the Parliament with certain kinds of information requested for the purpose of discharging the 1996 budget. The European Parliament responded strategically to this non-cooperative attitude by postponing the decision on discharge, and thereby making it clear to the Commission that it insisted on receiving the requested information. In its decision to postpone the discharge for the 1996 financial year, the committee on Budgetary Control included a threat: "In proposing that the discharge be postponed, it is by no means your rapporteur's intention to start a witch hunt against the Commission leading eventually to its inevitable resignation. On the contrary, this is constructive criticism, and your rapporteur $[\ldots]$ just wants to set the ball rolling. The Commission must be aware, however, that if it fails to heed the barking of the watchdogs, no one will protect it from the bloodhounds". ${ }^{869}$

This dispute between the committee on Budgetary Control and the Commission resulted in the establishment of a Committee of Independent Experts whose task it was to investigate charges of serious mismanagement levelled against the Commission. Following the publication of its devastating conclusions $^{870}$, the Santer Commission resigned on 15 March 1999. ${ }^{871}$ According to Jan Mulder (ALDE), chair of the committee on Budgetary Control, this event still influences the contacts between the Commission and the Parliament in the sense that the fear of a refusal to grant discharge ensures the cooperation of the Commission throughout the discharge procedure. 872

Granting discharge is more than a formal statement by the Parliament that it endorses the implementation of the budget over a specific financial year. It is not a purely ex post exercise. A strategic use of the discharge procedure offers the Parliament the opportunity to influence ex ante future executive action. The procedure is as follows: the Parliament lays down ex ante observations and comments regarding the future implementation of the budget in the decisions when giving discharge, and subsequently scrutinizes ex post whether these

\footnotetext{
${ }^{867}$ Lenaerts/Verhoeven (2002), p. 63.

868 Corbett/Jacobs/Shackleton (2011), p. 287.

869 European Parliament (1998). CONT committee. Report on postponement of the discharge to be given to the Commission in respect of the implementation of the general budget of the European Community for the 1996 financial year (A4-0097/98, 18.3.1998), p. 20.

${ }^{870}$ Cf. Committee of Independent Experts (1999).

${ }^{871}$ For an inside report of the events that led to the fall of the Santer Commission see: Priestley (2008), pp. 144-202.

872 Interview with Jan Mulder, 30 May 2011.
} 
observations and comments have been taken into account by the executive. Because of the Parliament's increasing strategic use of the discharge procedure, discharge has become "as much a power as a procedure". ${ }^{873}$ At the same time, however, one must not get overexcited about the discharge procedure, due to the fact that scrutiny is limited by the time gaps involved. Executive action in the year $X$ is scrutinized by the Parliament in year $X+2 .{ }^{874}$

\subsubsection{Discharge to the Commission}

The general budget managed by the Commission represents by far the biggest share of the EU budget. In view of the complexity of EU budgetary matters, the committee on Budgetary Control has enhanced its ability to monitor the EU expenditure by allocating specific sectors to each of its members for a number of years. These members prepare the Parliament's response to special reports by the Court of Auditors in their specialist sector, which are subsequently used by the rapporteur who has the overall responsibility for drawing up the draft report on the discharge. Some of the other standing committees have also introduced systems whereby they are informed by the Commission every few months on the implementation of their areas of the budget. ${ }^{875}$ These standing committees forward their conclusions and recommendations to the committee on Budgetary Control.

Before giving discharge to the Commission, or for any other purpose in connection with the exercise of its powers over the implementation of the budget, the Parliament may ask to hear the Commission with regard to the execution of expenditure or the operation of financial control systems. The Commission is under a legal duty to submit any necessary information to the Parliament at the latter's request ( $c f$. Article 319 (2) TFEU). The Commission shall take all appropriate steps to act on the observations in the decisions giving discharge and on other observations by the European Parliament relating to the execution of expenditure, and, at the request of the Parliament or the Council, the Commission shall report on the measures taken in the light of these observations and comments ( $c f$. Article 319 (3) TFEU).

It has been described above that scrutiny through the discharge procedure is limited by the fact that executive action in year $X$ is scrutinized by the Parliament in year $X+2$. When it comes to discharge of the Commission's budget specifically, there are further factors which limit scrutiny through the discharge procedure. Firstly, the position of the Parliament is less strong if a discharge decision concerns a preceding Commission. ${ }^{876}$ Secondly, it must be noted that direct management by the Commission applies only to a limited part of the budget, as some $80-85 \%$ of EU funds are managed or monitored primarily by Member State authorities (the system of 'shared management'). ${ }^{877}$ The Commission is ultimately responsible for the spending under the system of

\footnotetext{
${ }^{873}$ Corbett/Jacobs/Shackleton(2011), p. 287.

874 Ibid. p. 290.

${ }^{875}$ Cf. Ibid. p. 290; and: European Parliament (2009). CONT committee. Handbook 2009 for New Members of the Committee on Budgetary Control (June 2009), pp. 10-11.

${ }^{876}$ Corbett/Jacobs/Shackleton (2011), p. 290.

877 European Parliament (2009). CONT committee. Handbook 2009 for New Members of the Committee on Budgetary Control (June 2009), p. 10.
} 
'shared management', but its ability to effectively steer the way in which these funds are managed is limited. In recent years, the spending by Member States under the system of 'shared management' has constantly been a controversial issue in the discharge procedure. In March 2010, the committee on Budgetary Control "regretted" that there were still "large-scale errors" in rural development, structural funds, research, energy and transport, enlargement and external action. ${ }^{878}$ In November 2010, the rapporteur, Jorgo Chatzimarkakis (ALDE), insisted that "the Commission should impose sanctions on countries with sloppy financial management and should be less sensitive to political pressure not to do so." He mentioned the example of Greece, where "for ten years money was sent without having an EU-compliant audit system in place. Here the taxpayer is literally fooled. If countries break rules, there should be consequences", he said. ${ }^{879}$ In March 2011, the committee on Budgetary Control nonetheless advised the plenum to grant discharge to the Commission. Chatzimarkakis said that "the choice as to whether to postpone or grant the discharge was a difficult one". He continued: "I still have a problem with the lack of transparency when it comes to spending by Member States under what we call 'shared management'. It is hard to explain to our citizens that we can't say exactly what $80 \%$ of the EU's budget is spent on and how. But this is a problem that cannot be addressed by the Commission alone, even though they are responsible in the end". ${ }^{800}$ Jan Mulder, the chairman of the committee on Budgetary Control, observed: "the fear of a refusal to grant discharge ensures the cooperation of the Commission throughout the discharge procedure. The problem, however, is that $80 \%$ of its money is being spent by the Member States. If we want to change anything, we have to change the culture in individual Member States. Year in year out, we make comments on that, but the Member States do not seem to take notice of that". 881

Despite the criticism voiced by the Parliament in recent years on the management of EU funds under the responsibility of the Commission, discharge has repeatedly been granted to the Commission. It is however doubtful whether the Parliament will continue to accept the situation that not all Member States seem to give full account of their spending under the shared management system. The Parliament is attempting with ever great insistence to force these Member States - via the Commission - to give full account for their spending. In April 2011, the committee on Budgetary Control recalled "its repeated invitations to the Commission to present a proposal for the introduction of mandatory national management declarations (NMDs) issued and signed at ministerial level, made public and duly audited by an independent auditor so far as such declarations are a necessary and indispensable first step

\footnotetext{
${ }^{878} C f$. European Parliament (2010). CONT committee. Report on discharge in respect of the implementation of the European Union general budget for the financial year 2008, Section III - Commission and executive agencies (A7-0099/2010, 26.3.2010); and EP Press Release of 23 March 2010 ('Signing off the 2008 budget: MEPs' proposals for better monitoring of EU spending').

${ }^{879}$ EP Press Release of 10 November 2010 ('Discharge: MEPs critical of EU 2009 budget implementation').

880 Ibid.

${ }^{881}$ Interview with Jan Mulder, 30 May 2011.
} 
to improve the efficiency of national systems and to enhance national accountability for the use of Union money”. ${ }^{882}$ In March 2012, the committee on Budgetary Control once again criticized inter alia the lack of sanctions for mismanagement in Member States. The Commissioner responsible for discharge issues, Algirdas Semeta, assured the committee that he would strive to improve management in this area. ${ }^{883}$ The discharge was subsequently given. However, it remains to be seen whether the Parliament will grant discharge in the future if the Commission does not take strong action against mismanagement in Member States.

\subsubsection{Discharge to EU agencies: two case studies}

EU agencies have not been discussed in depth in this book so far. This is definitely not because they are not important. On the contrary, their accountability - or perhaps better: their alleged lack of accountability - has received considerable academic interest. ${ }^{884}$ The limited attention paid to EU agencies in this book so far results from the fact that there has neither been an investigation by a committee of inquiry nor by a special committee into their actions. Standing committees do, however, endeavour to monitor their activities. This is particularly true for the committee on Budgetary Control, which scrutinizes the implementation of EU agency budgets in the course of the annual discharge procedure. Although the Treaty solely mentions giving discharge to the Commission, Financial Regulation No 1605/2002 extends the discharge procedure to $\mathrm{EU}$ agencies as well. ${ }^{885}$ Two cases concerning EU agencies - namely the European Police College (CEPOL) and the European Medicines Agency (EMA) - have arisen in the discharge procedure and are addressed below.

\subsection{The CEPOL-case}

The first case concerns the European Police College (hereafter: CEPOL). CEPOL is based some 70 kilometres from London in Bramshill. According to its website, it "brings together senior police officers across Europe with the aim to encourage cross-border cooperation in the fight against crime and maintenance of public security and law and order". ${ }^{886}$ In the course of the discharge procedure in 2009 (for the financial year 2007), the Parliament expressed concerns about findings of the Court of Auditors that members of

\footnotetext{
882 European Parliament (2011). CONT committee. Report on discharge in respect of the implementation of the general budget of the European Union for the financial year 2009, Section III - Commission and executive agencies (A7-0134/2011, 14.4.2011), p. 31.

883 Cf. EP Press Release of 26 March 2012 ('Budgetary Control Committee approves Commission spending for 2010').

884 Some examples of academic publications on the accountability of EU agencies are: Busuioc (2010a); Busuioc (2010b); Busuioc (2009); Curtin (2009), pp. 144-165; Vos (2003).

885 The Financial Regulation defines EU agencies as "the bodies set up by the Communities and having legal personality which actually receive grants charged to the budget"; $c f$. Article 185 (1) and (2) Council Regulation (EC, Euratom) No 1605/2002 of 25 June 2002 on the Financial Regulation applicable to the general budget of the European Communities (OJ L 248, 16.9.2002, pp. 1-48).

886 Website of CEPOL: http://www.cepol.europa.eu/.
} 
CEPOL's staff had used public money for private purposes. The European Anti-Fraud Office (OLAF) had already opened an internal investigation into these allegations. ${ }^{887}$ Nonetheless, discharge was ultimately granted for the financial year 2007.

CEPOL, however, lost all credit one year later. The Parliament stated: "the College's replies to the Court of Auditors' remarks are once again inadequate and the remedial measures it puts forward are too vague and non-specific to enable the discharge authority adequately to determine whether the College is capable of improving in future".888 CEPOL failed on the grounds of transparency as it did not publish any information on its website, among other things, about the governing board. It did not launch an external evaluation which had been specified in the Court of Auditors' findings in the 2007 financial report, it had weaknesses in procurement procedures, it did not comply with the rules governing expenditure on courses and seminars (which accounted for about $64 \%$ of its operational expenditure) and there were other irregularities, such as the absence of "a budgetary commitment preceding the legal commitment in nine cases covering a total of EUR 244 200". ${ }^{889}$ The Parliament further discussed some structural problems in CEPOL, such as its location in Bramshill, which the Parliament considered "a disadvantage, inter alia as regards recruitment and public transport links”. Another structural problem was the small size of CEPOL, which called into question its capacity to handle effectively the complexities of the EU's financial and staff regulations. Lastly, the Parliament "wondered" whether consideration should not be given to attaching CEPOL to Europol. 890 The Parliament consequently postponed the decision to grant discharge in May 2010.891 Five months later, the postponement was followed by a refusal to grant discharge for the implementation of the CEPOL budget for the financial year 2008. This was the first time that the European Parliament gave a negative discharge decision to an EU agency. An overwhelming majority (618 in favour, none against, 7 abstentions) found the lack of professionalism of the director responsible for the implementation of the 2008 CEPOL budget unacceptable. The Parliament also criticized the governing board for the failure to take disciplinary action against the director, for which the Parliament "insisted" that the governing board "must be held responsible". 892

\footnotetext{
887 European Parliament (2010). CONT committee. Report on discharge in respect of the implementation of the budget of the European Police College for the financial year 2008 (A7-0075/2010, 26.3.2010), p. 9.

888 Ibid. p. 7.

889 Ibid. p. 9.

890 Ibid. p. 7.

${ }^{891}$ European Parliament decision of 5 May 2010 on the closure of the accounts of the European Police College for the financial year 2008 (C7-0198/2009 - 2009/2127(DEC)).

892 European Parliament's decision of 7 October 2010 on discharge in respect of the implementation of the budget of the European Police College for the financial year 2008 (C7-0198/2009-2009/2127(DEC)).
} 
The CEPOL saga continued in May 2011, when the Parliament again postponed the decision to grant discharge to CEPOL. ${ }^{893}$ This decision was taken due to CEPOL's "persistent lack of compliance with the Financial Regulation" ${ }^{894}$ The Parliament further observed that the multi-annual action plan - which the Parliament requested - lacked clarity and CEPOL's progress reporting was considered insufficient to allow a clear understanding of the implementation of concrete actions. ${ }^{895}$ The threat to refuse discharge apparently had effect. The committee on Budgetary Control concluded in October 2011 that CEPOL had improved its procurement procedures and practices, that its current director (appointed in February 2010) was more open about the accounts, and that CEPOL was moving towards meeting its targets. ${ }^{896}$ Accordingly, the Parliament granted discharge for the financial year 2009. ${ }^{897}$ Interestingly, this discharge decision did not address whether CEPOL should be abolished or attached to Europol. This seems to confirm that the Parliament merely threatened to do so in order to urge CEPOL to get things right.

The CEPOL case shows how the Parliament can hold an EU agency to account. It first informed itself thoroughly about CEPOL's implementation of the budget. The Parliament, notably the committee on Budgetary Control, subsequently debated its findings with CEPOL. As CEPOL did not manage to give a satisfying justification for the findings of financial maladministration, the Parliament chose to penalize CEPOL by refusing to grant discharge.

\subsection{The EMA case}

The second case concerns the London-based European Medicines Agency (hereafter: EMA ${ }^{898}$ ). The EMA is responsible for the scientific evaluation of medicines developed by pharmaceutical companies for use in the European Union. The European Commission decides on the basis of the outcome of EMA's evaluations whether or not a specific medicine can be authorized for the European market.

In May 2011, the Parliament postponed the decision to grant discharge to the EMA's 2009 budget. The committee on Budgetary Control reported that there was no proper guarantee of the independence of experts hired to carry out scientific evaluations of medicines and that some experts had conflicting interests in the case of the evaluation of a specific anorectic medicine,

893 European Parliament decision of 10 May 2011 on discharge in respect of the implementation of the budget of the European Police College for the financial year 2009 (OJ L 250, 27 September 2011, p. 260).

${ }^{894} C f$. European Parliament resolution of 10 May 2011 with observations forming an integral part of its Decision on discharge in respect of the implementation of the budget of the European Police College for the financial year 2009 (OJ L 250, 27 September 2011, pp. 261-267), p. 262.

895 Ibid. p. 266.

${ }^{896}$ European Parliament (2011). CONT committee. Second report on discharge in respect of the implementation of the budget of the European Police College for the financial year 2009 (A7-0330/2011, 6.10.2011), p. 9.

${ }^{897}$ Ibid.

${ }^{898}$ Note that this is an unofficial acronym and that the agency is sometimes referred to as 'EMEA'. 
Benfluorex. Moreover, the EMA's management of procurement procedures and its lack of criteria for recruiting staff were criticized. ${ }^{899}$ Concerning conflicting interests, the committee was critical of EMAs former executive director, Thomas Lönngren, who accepted a position at a consultancy firm that advises drug companies on developing new treatments and on reducing the period to market introduction. According to the committee, "this move casts some doubt on the actual independence of the Agency". ${ }^{900}$ The Parliament therefore urged the EMA to undertake, by 30 June 2011, a thorough verification of the effective use of the existing procedures regarding the identification and management of conflicts of interest for its staff and experts, and to adopt an action plan to remedy the shortcomings in the procurement procedures. ${ }^{901}$

Michèle Rivasi (Greens/EFA) observed directly after the vote on the discharge decision: "The EP has today sent a strong message to the EMA to pull up its socks. Conflicts of interests of its staff, problems with access to documents, poor quality scientific analysis, accounting irregularities... the list of problems repeatedly highlighted by the Court of Auditors is long. This agency does not operate properly and the EMA needs to urgently undergo deep surgery". ${ }^{902}$

At the end of June 2011, the EMA sent a reply to the Parliament in which it stressed that improvement actions had already been taken on all areas where issues had been raised by the Parliament. ${ }^{903}$ The Parliament acknowledged the EMA's actions to remedy shortcomings by granting discharge for the 2009 financial year. However, some concerns remained. The Parliament expressed its desire that the impartiality and independence of EMA experts should be assessed thoroughly upon their appointment. Furthermore, the Parliament called on the EMA to improve procurement procedures and to keep the Parliament better informed of the results of actions requested. Discharge was ultimately granted in October 2011 for the financial year 2009.904

However, in May 2012, the Parliament postponed the decision to grant discharge to the EMA for the financial year 2010.905 The committee on Budgetary Control inter alia asked for an action plan to improve procurement

${ }^{899}$ European Parliament (2011). CONT committee. Report on discharge in respect of the implementation of the budget of the European Medicines Agency for the financial year 2009 (A7-0153/2011, 15.4.2011), pp. 8-12.

900 Ibid.p. 10.

${ }_{901}$ Ibid.p. 13.

902 This quotation was taken from the Greens/EFA website: http://www.greensefa.eu/budget-discharge-3757.html.

${ }_{903}$ EMA's reply of 23 June 2011 to the European Parliament committee on Budgetary Control. The letter is online available under:

http://www.europarl.europa.eu/meetdocs/2009_2014/documents/cont/dv/emea_replies_/ emea_replies_en.pdf.

904 European Parliament decision of 25 October 2011 on discharge in respect of the implementation of the budget of the European Medicines Agency for the financial year 2009 (OJ L 313, 26.11.2011, pp. 27-28).

905 European Parliament decision of 10 May 2012 on discharge in respect of the implementation of the budget of the European Medicines Agency for the financial year 2010 (OJ L 286, 17.10.2012, p. 377). 
and contract management and it sought assurances as to the impartiality of the EMA's employees and of national experts temporarily seconded to it. ${ }^{906}$

Interestingly, the EMA case shows that Parliament uses the discharge procedure for purposes other than solely scrutinizing 'the implementation of the budget' as prescribed by the TFEU and the Financial Regulation. ${ }^{907}$ The question of whether or not the EMA's experts are sufficiently independent has no direct connection to the way in which the EMA implemented its budget in a specific year. The Parliament thus deploys its discharge procedure (or perhaps better: its discharge power ${ }^{908}$ ) to force through its desires, even beyond the implementation of the budget.

\subsection{Other sanctions vis-à-vis EU agencies}

The refusal to grant discharge is only one of various ways in which the Parliament can sanction EU agencies which do not implement their budget properly. In its capacity as a budgetary authority (together with the Council), the Parliament can further use the 'power of the purse' by cutting down the budgets of agencies (or merely threatening to do so). The Parliament regularly uses its budgetary power in a strategic way by setting up so-called budgetary reserves. The procedure is as follows: in the course of drafting a budget, the budgetary authority may set up reserves to specific budget lines "where there are serious grounds for doubting the adequacy of the appropriations or the possibility of implementing [...] the appropriations entered on the lines concerned". 909 If the Parliament makes use of this ability, it can formulate conditions, such as a request for an explanation or extra information, for these reserves to be released. The Parliament makes full use of this opportunity, but as the conditions for releasing the reserves are as a rule fulfilled even before the budgetary procedure is finalized, this generally does not appear in the ultimate budget. This ability to set up budgetary reserves was also used as a pressure mechanism in 2010 vis-à-vis CEPOL, when the Budgets committee decided to freeze a sum of EUR 425,000 for CEPOL until it received satisfactory information on the follow-up to be given in response to the negative discharge decision of 7 October 2010.910

If $\mathrm{EU}$ agencies fail to comply with the obligations deriving from parliamentary comments accompanying the discharge decision ${ }^{911}$, the Parliament can also

${ }_{906}$ European Parliament (2012). CONT committee. Report on discharge in respect of the implementation of the budget of the European Medicines Agency for the financial year 2010 (A7-0107/2012, 4.4.2012).

${ }_{907} \mathrm{Cf}$. Article 319 TFEU in conjunction with Article 145 Council Regulation (EC, Euratom) No $1605 / 2002$ of 25 June 2002 on the Financial Regulation applicable to the general budget of the European Communities (OJ L 248, 16.9.2002, pp. 1-48).

${ }_{908}$ Cf. Corbett/Jacobs/Shackleton (2011), p. 287.

${ }^{909} \mathrm{Cf}$. Article 43 (1) sub b Council Regulation (EC, Euratom) No 1605/2002 of 25 June 2002 on the Financial Regulation applicable to the general budget of the European Communities (OJ L 248, 16.9.2002, pp. 1-48).

910 Phillips (2010).

911 Cf. Article 319 (3) TFEU in conjunction with Article 147 Council Regulation (EC, Euratom) No 1605/2002 of 25 June 2002 on the Financial Regulation applicable to the general budget of the European Communities (OJ L 248, 16.9.2002, pp. 1-48). 
bring an action before the CJEU pursuant to Article $265 \mathrm{TFEU}$ for failure to implement its budget properly. ${ }^{912}$ It must be noted, however, that the power of the purse and the discharge procedure apply only vis-à-vis the large majority of agencies which are funded from the EU budget. The Parliament cannot deploy the discharge procedure and the power of the purse to gain influence over selffunded agencies, notably the Office for Harmonization in the Internal Market (OHIM) and the Community Plant Variety Office (CPVO).

In its capacity as a legislative authority (again with the Council), the Parliament can also try to pass secondary legislation to restructure or even to abolish agencies. ${ }^{913}$ The Parliament actually hinted at this option in its discharge decisions of 2010 concerning CEPOL. It changed its tone from a more tentative 'wondering' (in May 2010) to a more decisive 'suggesting' (in October 2010) when referring to the abolishment of CEPOL by means of attaching it to another EU agency (Europol). ${ }^{914}$ In May 2011, the Parliament went further by explicitly recommending that CEPOL be merged with Europol in the near future ${ }^{915}$, but this recommendation was interestingly not voiced again in October 2011, when the Parliament granted discharge to CEPOL. It thus seems that the Parliament deploys its power to restructure or abolish agencies strategically in order to gain influence over the functioning of specific EU funded agencies.

As a matter of course, the Parliament can always exert political pressure on agencies by criticizing them. The effectiveness of this mechanism should not be underestimated. The Danish MEP Anne Jensen (ALDE) observed: "I can tell you that managers of the agencies do not find it nice to come and be exposed to this public criticism. So, our experience is that they actually do deal with it." 916

\subsubsection{Investigations regarding the implementation of EU legislation}

Although the Parliament lacks a formal right to initiate legislation in any significant policy field, it can block legislation by veto in a large range of policy areas and it therefore plays a vital role in the EU legislative process. There appears to be consensus amongst its Members that the Parliament should pay a great deal of attention to its legislative task (and it does). However, Shackleton signals a difference in culture in the Parliament when it comes to what should happen after a piece of legislation has been adopted. He observes that there are a number of MEPs who tend to think that everything that happens after the legislation is passed, namely the implementation, "is kind of less noble". ${ }^{917} \mathrm{He}$ notes that that this is a sort of "Mediterranean view", whereas a more "northern view" is that implementation is what really counts for EU citizens. In line with this "northern view", Shackleton argues that the Parliament should

\footnotetext{
912 Cf. Article 6 (3) Annex VI, European Parliament's Rules of Procedure.

913 Cf. Scholten (2010), p. 9.

914 Ibid. p. 13.

915 Cf. European Parliament resolution of 10 May 2011 with observations forming an integral part of its Decision on discharge in respect of the implementation of the budget of the European Police College for the financial year 2009 (OJ L 250, 27 September 2011, pp. 261-267), p. 267.

916 Cf. Scholten (2010), p. 8.

917 Interview with Michael Shackleton, 15 April 2010.
} 
check whether legislation is being implemented properly. ${ }^{918}$ Although the main focus still lies on making legislation, Shackleton signals that the Parliament seems to concentrate more and more on the implementation of EU legislation: "I tend to feel that there is a sense in which the Parliament will be driven to consider the actual implementation of legislation more over time because Parliament is now jointly responsible for the legislation that generates consequences. Before, Parliament was in a position to say 'well, you might have accepted this or that to happen' because it was only done by the Council. But now, suddenly problems arise in relation to Directives that Parliament was involved in some years ago". .19

There are various ways in which the Parliament scrutinizes the implementation of EU legislation. The most obvious and commonly used of these is the questioning of executive actors - such as Commissioners and EU agency directors - on the way in which they implemented a certain piece of EU legislation. A more thorough way of scrutinizing the implementation of EU legislation is the conduct of in-depth investigations. Such investigations may be conducted for a specific reason, for example following allegations of inadequate implementation, but also as a routine event. Investigations into the implementation of EU legislation may further differ as to who conducts them. Sometimes standing committees conduct such investigations themselves, but the Parliament may also set up a temporary committee (a committee of inquiry or a special committee) to carry out such an investigation. Standing committees may further mandate external experts to do this, as was the case for the investigations into the implementation of inter alia the EU legislation on air passenger rights, the legislation on the European Arrest Warrant, the Services Directive, the Habitats Directive, and Article 80 TFEU on the principle of solidarity in the field of Border Checks, Asylum and Immigration. 920

If a standing committee decides to investigate the implementation of $\mathrm{EU}$ legislation itself, it can draw up an own-initiative report. An example of an investigation of the implementation of EU legislation is discussed below.

\section{The implementation of EU legislation on Transmissible Spongiform} Encephalopathies (TSE) and related feed and food controls

Transmissible Spongiform Encephalopaties (TSEs) are a family of diseases occurring in human and animals and are characterized by a degeneration of brain tissue resulting in a 'sponge-like' appearance and eventually leading to death. The TSE family includes diseases such as Creutzfeld Jakob Disease in humans, Bovine Spongiform Encephalopathy (BSE) in cattle, scrapie in small ruminants (sheep and goats) and Chronic Wasting Disease (CWD) in cervids. BSE is considered to be transmissible to humans by the oral route causing

\footnotetext{
918 Ibid.

919 Ibid.

920 These investigations were conducted by Price Waterhouse Coopers, the European Institute of Public Administration (EIPA), Rambøll Management Consulting, Milieu Ltd., and Eurasylum Ltd. respectively.
} 
variant Creutzfeld-Jacob Disease (vCJD). ${ }^{921}$ BSE reached epidemic proportions in Europe in the mid 1990s. Section 2.5.2 discusses the work of the committee of inquiry which investigated the handling of the BSE crisis. Section 3.6.1 addresses the work of the BSE follow-up committee (the special committee which monitored the follow-up to the BSE inquiry). The parliamentary inquiry into the handling of the BSE crisis (and its follow-up) led to the introduction of a series of measures aimed at eradicating BSE and other TSEs. About fifteen years after the BSE crisis hit its peak, the (standing) committee on the Environment, Public Health and Food Safety (ENVI committee) wrote a report in which it took stock of the measures taken following the BSE crisis. The rapporteur was Dagmar Roth-Behrendt (PES), who had previously chaired the BSE follow-up committee. Roth-Behrendt declared herself satisfied with the fact that the number of positive BSE cases in the EU had decreased from 2167 cases in 2001 to 67 cases in 2009. She considered this "important evidence that the EU's TSE eradication measures have been successful”. ${ }^{922}$ However, the rapporteur pointed out that "this downward trend must not lead to less stringent control and surveillance measures in the future" and that "the highest level of consumer protection and food safety should always be the overarching goal of any measures in this field". ${ }^{923}$ There were also some critical remarks. The report was critical of changes proposed by the Commission to relax surveillance mechanisms and it condemned the bad quality of reporting by some Member States. ${ }^{924}$

Investigations into the implementation of EU legislation demonstrate that the Parliament is not only interested in drafting legislation, but that it also cares about its implementation. Investigations of this kind also show that the Parliament is not only willing to hold the executive to account when it is likely that it can make political heads roll. In fact the contrary is true. The ENVI committee's report is just one of many reports which the Parliament produces on the implementation of legislation. These reports may indeed seem less exciting than reports on highly controversial topics, such as the handling of the BSE crisis ${ }^{925}$ or the alleged use of European countries by the CIA for the transport and illegal detention of prisoners ${ }^{926}$. However, it cannot be said that this kind of reports is less important for EU citizens as it is not the legislation alone - rather its implementation - which really counts. It is therefore necessary to regularly examine whether or not existing legislation is implemented properly in practice.

\footnotetext{
921 European Parliament (2011). ENVI committee. Report on EU legislation on Transmissible Spongiform Encephalopathies (TSE) and on related feed and food controls implementation and outlook (A7-0195/2011, 26.5.2011), p. 9.

922 Ibid. p. 10.

923 Ibid. p. 10.

924 Ibid. pp. 10-11.

${ }_{925} \mathrm{Cf}$. Section 2.5.2.

${ }^{926} \mathrm{Cf}$. Section 3.6.5.
} 


\subsection{Conclusion}

The bulk of parliamentary work is done within Parliament's standing committees. Chapter 2 and Chapter 3 have shown that temporary committees are used to investigate issues which have raised particular public concern in depth. Standing committees, however, are generally responsible for day-to-day issues. The fact that temporary committees usually attract more media coverage for their scrutiny work than standing committees by no means implies that the latter's activities are less important. Standing committees endeavour to keep executive actors in the European Union in check in an ongoing manner. They do so by questioning executive actors, such as the Commission, the Council and EU agencies, on what they do and why, and by examining reports received from them.

\section{Four types of accountability investigations}

This chapter addressed the investigations which the standing committees conduct as a means of holding executive actors to account. Standing committees conduct four types of such investigations.

The first category, the inquiry-type investigations, resembles the investigations conducted by the temporary committees described in the previous chapters. Inquiry-type investigations aim to clarify who is responsible for a specific past incident. This type of investigation is a useful tool for standing committees to hold executive actors to account. However, inquirytype investigations conducted by standing committees are on a considerably smaller scale than the investigations conducted by temporary committees. The smaller scale applies inter alia to the number of MEPs who are actively involved, the number of meetings specifically held for the investigation, the amount of staff support given to it, and the degree of media coverage. Due to these restrictions, the Parliament cannot do without temporary committees, as standing committees are simply not equipped to investigate large-scale issues such as the handling of the BSE crisis or the CIA flights.

The second category is investigations conducted by the Parliament's committee on Petitions in response to petitions filed to the Parliament by EU citizens. These investigations can facilitate redress for petitioners in specific cases and the petitions filed to the Parliament may draw the Parliament's attention to abuses or irregularities in the EU sphere which it can subsequently investigate more thoroughly. Depending on the nature of a petition, the Petitions committee may choose to investigate an issue on its own or it may refer the matter to another parliamentary committee. The 'Equitable Life case' is an example of this. A significant number of petitions regarding the collapse of the Equitable Life Assurance Society, a British life insurance company, ultimately lead to the establishment of a committee of inquiry whose task it was to investigate alleged contraventions or maladministration in the application of an EU Directive (Directive 92/96/EEC) by the UK.

The third category is investigations the Parliament conducts in the course of the discharge procedure. In order to decide whether or not the Parliament should grant discharge to EU executive actors, it investigates whether these executive actors properly implemented their budget over a specific financial year. By so doing, the Parliament finds itself in a strong position, as the ability 
to refuse to grant discharge represents a serious threat to executive actors. The Parliament uses its strong position strategically in order to ensure a cooperative attitude from executive actors. The Commission seems very sensitive to this pressure. The problem, however, is that direct management by the Commission only applies to a limited part of the budget, as some $80-85 \%$ of EU funds are managed or monitored primarily by Member States authorities (the so-called system of 'shared management'). The Commission is ultimately responsible for the spending under the system, but its ability to effectively steer the way in which these funds are managed seems limited. EU agencies also seem very sensitive to pressure from the Parliament exerted during the discharge procedure. Two case studies of EU agencies (CEPOL and EMA) demonstrate specifically how the Parliament makes a strategic use of its budgetary powers to force through its political desires. The CEPOL case shows how the Parliament deploys the discharge procedure to urge reforms within CEPOL. The Parliament increased the pressure on CEPOL by setting up so-called budgetary reserves and by formulating conditions for releasing these reserves. The EMA case demonstrates how the Parliament uses the discharge procedure not only to investigate the implementation of the budget, but also to investigate issues which are not directly connected. The reason for this is that the discharge procedure offers the best prospect of success for securing political commitments from these executive actors, because of their fear that the Parliament will refuse to discharge their budget. The Parliament thus uses a procedure for a purpose other than that for which it was initially created. This strategic use of its powers is not new for the Parliament. Rather it is yet another example of what Chambers has described as "the European Parliament's tradition of exploiting new methods to gain influence". ${ }^{927}$

The fourth category is investigations into the implementation of $\mathrm{EU}$ legislation. In the course of these investigations, the Parliament scrutinizes the way EU legislation is implemented in practice. Although the main focus still lies on making legislation, the Parliament seems to concentrate ever more on the implementation of EU legislation. The main explanation for this is the fact that the Parliament's role in the legislative process has become more important over time. The more influence the Parliament has on the adoption of EU legislation, the more concerned it seems to be about the actual implementation of this legislation. The increasing parliamentary interest in the actual implementation of EU legislation is applaudable, as it is the implementation of legislation which really counts for EU citizens. It is therefore necessary to ascertain regularly that existing legislation is being implemented properly.

\section{The importance of investigative activities of standing committees}

Whereas accountability investigations conducted by temporary committees may appeal more to the imagination, this chapter has shown that accountability investigations conducted by standing committees are an indispensable tool for the accountability activities of the European Parliament.

\footnotetext{
927 Chambers used these words to describe the conditional motion of censure which the Parliament adopted following the inquiry into the handling of the BSE crisis ( $c f$. Section 2.5.2); $c f$. Chambers (1999), p. 96.
} 
Firstly, because these investigations enable the Parliament to investigate issues which fall outside the scope of the right of inquiry or for which there is no majority support for establishing a temporary committee. Secondly, these investigations are different from investigations conducted by temporary committees. Temporary committees mainly concentrate ex post on specific past incidents on an ad-hoc basis. They examine what happened, they pass a judgement, and they put forward recommendations for the future. Thereupon the temporary committee ceases to exist and the scrutiny of the follow-up actions lies in the hands of the standing committees. Standing committees, unlike temporary committees, concentrate on executive action on a continuous basis. In particular the discharge procedure shows that the Parliament's scrutiny activities are not only of an ex post nature, but also ongoing and ex ante. The discharge decision generally goes further than merely giving an (ex post) approval or refusal for the discharge of the handling of the budget in a preceding financial year. It also contains ex ante recommendations and the Parliament scrutinizes the follow-up of these recommendations in an ongoing manner. In this context, ex ante, ex post and ongoing scrutiny mutually influence and reinforce one another. The strength of this scrutiny lies mainly in its continuous nature and the degree of specialization, which is generally higher in the standing committees than in the temporary committees.

This chapter has shown that the activities of standing committees and the activities of temporary committees partly overlap. However, rather than being in competition with one another, it can be concluded that standing committees and temporary committees complement each other in the Parliament's efforts to hold executive action in the EU to account. 


\section{CONCLUSION}

Academic literature assumes that executive power escapes accountability in the European Union. The argument goes that the considerable increase in executive power in the European Union in recent decades has not been matched by an equivalent increase in mechanisms to keep this power in check. As the only directly elected institution at the EU level, the European Parliament has an important role to play in holding executive power in the EU to democratic account. To that end, the Treaties grant the European Parliament several powers. Questions can be asked, reports and other written documents can be requested, debates can be held with executive actors, and investigations can be conducted into executive action.

This book has examined parliamentary investigations as a means of holding executive actors in the EU to account. In the context of this book, 'parliamentary investigation' is defined as 'a study carried out by a parliamentary committee under the authority of the Parliament. The parliamentary committee gathers information and, once complete, forwards its conclusions to the Parliament, which can take action on that basis'. Not all of the kinds of investigations of the European Parliament have been analysed. A distinction has been made between 'accountability investigations' and 'nonaccountability investigations', the former being investigations aimed at holding executive actors to account and the latter being investigations with other objectives, such as preparing legislative decision-making. With the central topic of alleged accountability deficits in mind, only the 'accountability investigations' have been examined. In particular, this book has examined how the European Parliament uses its investigative powers to hold executive actors in the European Union to account.

To that end, the legal position of the European Parliament's investigative function and the practice of investigations by the European Parliament to date have been analyzed.

\subsection{Three types of committees}

The European Parliament deploys three types of committees to conduct parliamentary investigations: the temporary committees of inquiry, the temporary special committees, and the standing committees.

\section{Temporary committees of inquiry}

Temporary committees of inquiry are specifically designed to conduct 'accountability investigations'. Article 226 TFEU stipulates that they can be established to investigate 'alleged contraventions or maladministration in the implementation of Union law, except where the alleged facts are being examined before a court and while the case is still subject to legal proceedings'. Committees of inquiry are equipped with more powers than other committees of the European Parliament. These powers, which are laid down in an interinstitutional agreement concluded in 1995 between the Parliament, the Commission and the Council, include powers inter alia concerning the hearing 
of witnesses and access to documents. These powers are fairly weak compared to those held by many committees of inquiry of Member State parliaments. Committees of inquiry of the European Parliament cannot summon specific persons, they cannot administer oaths, they cannot issue penalties for false testimonies, and - even though they have a formal right of access to documents - they lack an autonomous right to seize documents from executive actors.

Since 1993, when the right of inquiry was recognized in primary EU law for the first time, the Parliament has set up three committees of inquiry. The committees were on several occasions effectively hampered by their fairly weak legal position. They experienced difficulties inter alia with ensuring the attendance of witnesses and ensuring access to relevant documents. The weak position was felt particularly in the relations with the Council and the Member States. The close ties with the Commission, however, ensured a responsive attitude from the Commission in the course of the inquiries.

An important indicator for determining the success of an inquiry is the impact that it has had on the issue under investigation. Despite the legal constraints, the three inquiries did have considerable impact in their respective domains. Besides putting the respective issues on the agenda, the three inquiries all had a life beyond the conclusion of the final reports. The issues remained on the political agenda even after the committees of inquiry ceased to exist. Furthermore, the inquiries, especially the Transit and BSE inquiries, led to concrete changes in policy and legislation which almost certainly would not have taken place had the inquiries not been conducted.

\section{Temporary special committees}

The second type is the temporary special committees. In contrast with the right of inquiry ex Article 226 TFEU, the establishment of special committees has no basis in the TFEU. These committees are set up on the basis of the Rules of Procedure of the European Parliament. Whereas since 1993 three inquiries were held, the Parliament has set up twelve temporary special committees in the same period. Unlike the temporary committees of inquiry, special committees do not have additional powers of investigation. Special committees, however, encounter fewer formal restrictions than committees of inquiry. The scope of the right of inquiry is restricted to 'cases of alleged contraventions or maladministration' and to matters which are not being examined simultaneously by a court. Special committees are not subject to such restrictions. As a consequence, special committees have been established to conduct several sorts of investigations, including 'non-accountability investigations'. This book examined five 'accountability investigations' conducted by temporary special committees.

The fact that the Parliament establishes special committees more frequently than committees of inquiry could indicate a general preference for setting up special committees over setting up committees of inquiry. However, no evidence has been found in support of such a general preference. It seems it is not an unwillingness to set up committees of inquiry, but rather the narrow scope of the right of inquiry, which accounts for the more frequent use of special committees. In particular, the fact that the establishment of a committee of inquiry requires the existence of 'alleged contraventions or 
maladministration in the implementation of Union law' has proved an obstacle for a more frequent use of the right of inquiry.

The proceedings of the special committees bear a strong resemblance to the proceedings of committees of inquiry. Special committees also experienced difficulties in holding the Council and Member State authorities to account.

To avoid the embarrassment of a refusal to cooperate, the temporary committees of inquiry (in particular the 'Transit committee') sometimes exerted restraint in their quest to gather evidence from executive actors. Even though special committees have fewer formal powers than committees of inquiry, the special committees displayed no such restraint. It seems as if these special committees took a 'nothing-to-lose' approach. There is also a striking difference in the way committees of inquiry and special committees dealt with refusals to cooperate in the course of investigations. Refusals to cooperate in the course of inquiries generally led to great indignation in the Parliament, even though the executive actors were not legally obliged to cooperate. Special committees, however, accepted refusals in the course of their investigations with hardly a word of protest. This different attitude can be explained by the difference in standing; whereas special committees represent an internal parliamentary working group, committees of inquiry are set up on the basis of a Treaty provision and they are equipped with additional investigative powers. Hence, a parliamentary inquiry is a more serious procedure than an investigation conducted by a special committee. The right of inquiry is also used less often than the procedure to establish a special committee. Both types of committee consequently create a different atmosphere. Even in cases where formal powers are lacking, the European Parliament seems to presuppose some sort of moral obligation on persons, Member States, EU institutions and other bodies to cooperate in the course of an inquiry. In order to enforce these claims of a moral obligation to cooperate, the Parliament tends to remind noncooperative Member States and EU institutions - mostly wrongfully - of the duty of sincere cooperation ex Article 4 (3) EU Treaty. The work of special committees, in contrast, generally seems to be rather part of the 'daily business' of the European Parliament. These investigations have a more informal character. If a witness does attend, that is a bonus, and if someone decides not to accept an invitation, that is not considered a disgrace but it is accepted as part of the game.

\section{Standing committees}

The third type is the standing committees. The bulk of parliamentary work is done by its standing committees. Whereas temporary committees are generally used to investigate issues which have raised particular public concern in depth, standing committees are responsible for handling more day-to-day issues. Standing committees conduct various types of 'accountability investigations': inquiry-type investigations, investigations following petitions, investigations in the course of the discharge procedure, and investigations regarding the implementation of EU legislation.

Inquiry-type investigations resemble those conducted by temporary committees, but are on a considerably smaller scale. The smaller scale applies inter alia to the number of MEPs who are actively involved, the number of 
meetings specifically held for the investigation, the amount of staff support given to it, and (generally) the degree of media coverage. Due to these restrictions, the Parliament cannot do without its temporary committees, as standing committees are simply not equipped to investigate large-scale issues such as the handling of the BSE crisis and the CIA flights thoroughly.

Investigations following petitions are generally conducted by the Parliament's committee on Petitions. These investigations can facilitate redress for petitioners in specific cases and the petitions filed to the Parliament may also draw the Parliament's attention to abuses or irregularities in the EU sphere which it can subsequently investigate more thoroughly.

The Parliament also conducts investigations in the course of the discharge procedure. In order to decide whether the Parliament grants discharge to EU executive actors, it investigates whether they implemented their budget over a preceding financial year properly. By so doing, the Parliament finds itself in a strong position, as the ability to refuse to grant discharge represents a serious threat to executive actors. The Parliament's standing committees have proved able to use this threat strategically, not only in order to ensure a cooperative attitude from executive actors in the course of the discharge procedure, but also as a means of gaining influence over executive actors, especially over EU agencies.

Most of the standing committees also conduct investigations into the implementation of EU legislation. In the course of these investigations, the Parliament scrutinizes how EU legislation is being implemented in practice. Although the main focus still lies on making legislation, the Parliament seems to concentrate ever more on scrutinizing the implementation of EU legislation. The increasing parliamentary interest in the actual implementation of EU legislation is applaudable, as it is the implementation of legislation which really counts for EU citizens. It is therefore necessary to ascertain regularly that existing legislation is being implemented properly.

'Accountability investigations' thus are conducted by three types of committees of the European Parliament. Temporary committees bear some inherent advantages over standing committees. A first advantage of temporary committees is that they bring together MEPs from several standing committees with specific knowledge of the issues under investigation. The establishment of a temporary committee further prevents arguments as to which standing committee should deal with a given issue. Another central advantage is that issues are taken out of standing committees which are generally already overrun. One could say that if an issue is not being dealt with by a temporary committee, it will not be possible to really deal with it in depth. Additionally, there is an agenda-setting argument. The establishment of a temporary committee guarantees that the spotlight is put on a specific issue and that the issue appears not only on the committee agenda, but also on the plenary agenda and, in all probability, even on agendas outside the Parliament. Despite the advantages of temporary committees, it must be noted that also standing committees are indispensable for the investigative activities of the European Parliament. Firstly, because these investigations enable the Parliament to investigate issues which fall outside the scope of the right of 
inquiry and/or for which there is no majority support to establish a temporary committee. Secondly, these investigations are different to those conducted by temporary committees. Temporary committees mainly concentrate ex post on specific past incidents on an ad-hoc basis. They pass a judgement and they put forward recommendations for the future. Thereupon the temporary committee ceases to exist and the scrutiny of the follow-up actions lies in the hands of the standing committees. Standing committees are more concerned than temporary committees with executive action on a continuous basis. The discharge procedure in particular shows that the Parliament's scrutiny activities are not only of an ex post nature, but also 'ongoing' and ex ante. Discharge decisions generally go further than merely stating (ex post) an approval or a refusal to discharge the actor for the handling of the budget in a preceding financial year. They usually also contain ex ante recommendations for the future, and the Parliament scrutinizes the follow-up to these recommendations in an ongoing manner. In this context, ex ante, ex post and ongoing scrutiny mutually influence and reinforce one another. The strength of this scrutiny mechanism lies mainly in its continuity and the degree of speciality, which are generally safeguarded better in the standing committees than in the temporary committees.

The activities of standing committees and the activities of temporary committees thus partly overlap. However, rather than being in competition with one another, it may be concluded that standing committees and temporary committees complement each other in the Parliament's efforts to hold executive actors in the EU to account.

\subsection{Formal investigative powers; status quo and future perspectives}

Whereas temporary special committees and standing committees rely on the general array of powers of the European Parliament, temporary committees of inquiry are granted additional powers of investigation. The 1995 Interinstitutional Agreement on the detailed provisions governing the exercise of the European Parliament's right of inquiry includes powers concerning inter alia the hearing of witnesses and access to documents. However, these powers are fairly weak. On the basis of the 1995 Interinstitutional Agreement, committees of inquiry can require Member States and institutions and bodies of the European Union to designate officials or servants to a committee of inquiry. However, this still falls short of a general right of summons, since it is the authorities that decide which person they designate. Other persons, such as national ministers, agency directors, and private persons, can only be invited (i.e. not summoned) to appear before committees of inquiry. Inquiry committees also lack legal mechanisms to enforce the attendance of witnesses and they lack direct legal mechanisms to penalize unjustified refusals to appear before committees of inquiry.

The 1995 Interinstitutional Agreement also stipulates that authorities of the Member States and the EU institutions or bodies shall provide a temporary committee of inquiry, where it so requests or on their own initiative, with the documents necessary for the inquiry, save where prevented from doing so by reasons of secrecy or public or national security. However, committees of inquiry lack a right to seize files to prevent the authorities under investigation 
from concealing incriminating information. This means practically, that the authorities under investigation are in the strong position of being able to decide which documents they forward to committees of inquiry, and when they do so. Furthermore, committees of inquiry have no legal mechanisms to enforce the release of documents and they lack direct legal mechanisms to penalize unjustified refusals to forward documents.

Unlike the committees of inquiry of many Member State parliaments, European Parliament inquiry committees cannot swear in witnesses and witnesses cannot be punished if they give false testimony. Witnesses appearing before committees of inquiry of the European Parliament also have a unilateral right to provide testimony in camera.

The 1995 Interinstitutional Agreement was the result of laborious negotiations between the European Parliament, the Commission and the Council. Although the Council, which advocated weak powers for committees of inquiry, came off best, the European Parliament nevertheless accepted the result, stating: "The European Parliament may not be entirely satisfied with the compromise reached. However, the result seems acceptable and necessary as a means of acquiring experience of parliamentary committees of inquiry over the next few years. Rejection of the compromise would prevent the creation of this important means of parliamentary scrutiny for an indefinite period. Instead, the compromise will make it possible to examine in public any shortcomings in the present rules on the basis of practical examples and thereby to create the necessary political pressure to bring about a revision of the provisions". ${ }^{928}$

\section{Parliamentary proposals for a new regulation on the right of inquiry}

More than fifteen years after its adoption, the 1995 Interinstitutional Agreement is still in place. The Lisbon Treaty has granted the Parliament an exclusive right of initiative for a new regulation on the detailed provisions governing the exercise of the right of inquiry. On 30 November 2009, one day before the Lisbon Treaty entered into force, the British Labour MEP David Martin was appointed as rapporteur to prepare such a regulation on the right of inquiry. The standing committee on Constitutional Affairs adopted a first Draft Proposal for such a regulation in October 2011. This Draft Proposal of 2011 included strong powers for committees of inquiry, such as a right to summon any EU resident, a right to swear in witnesses, a right to require national judicial and other authorities to assist committees of inquiries in the course of their proceedings, and a far-reaching right of access to documents. Probably as a result of informal interinstitutional bargaining, these farreaching proposals had been moderated somewhat by the plenary in May 2012. Undoubtedly under pressure from the Council, the initial proposals for giving committees of inquiry strong powers vis-à-vis persons and authorities at the Member State level have been amended in the new proposal, the Draft Proposal of 2012. For example, the assistance of national authorities in the course of inquiries can no longer be required, as the Draft Proposal 2011 stipulated, but can only be asked for. Hence there is no explicit legal obligation

\footnotetext{
${ }_{928}$ European Parliament (1995). Committee on Institutional Affairs. Report on the right of
} inquiry of the European Parliament (A4-0003/95, 12.1.1995), p. 14. 
to cooperate. Furthermore, in contrast with the Draft Proposal of 2011, the Draft Proposal of 2012 does not contain an arrangement for swearing in witnesses. However, despite these moderations, the Draft Proposal of 2012 still includes far-reaching powers, such as a right to summon any EU resident via the competent national authorities. Furthermore, the Draft Proposal of 2012 includes a provision which obliges Member States to punish infringements in the course of inquiries, such as groundless refusals to send documents or appear before committees of inquiry. It is doubtful whether the Commission and, particularly, the Council will ultimately agree with these proposals. The proposed powers vis-à-vis persons and authorities at the Union level, on the contrary, may very well survive the interinstitutional negotiations. At present, the European Ombudsman has stronger investigative powers vis-à-vis persons and authorities at the Union level than committees of inquiry of the European Parliament. The European Ombudsman can summon any official and servant of the European Union to testify before him and EU authorities are obliged to supply the Ombudsman with any information he has requested from them. It would be reasonable to bring the powers of committees of inquiry of the directly elected European Parliament at least into line with the powers of the European Ombudsman, who is appointed by the European Parliament.

\section{Proposals based on the book's findings}

This book has revealed several bottlenecks in the legal position of committees of inquiry. It has been concluded that, in a formal legal sense, the right of inquiry is rather weak. However, despite this de jure weak position, committees of inquiry have proved to be de facto in a rather strong position vis-à-vis the 'core EU executive' ${ }^{299}$, the European Commission. Relations with authorities at the Member State level have proved problematic, both de jure and de facto. With this in mind, it would perhaps be tempting to recommend that committees of inquiry should be equipped with stronger legal powers vis-à-vis all EU executive actors, both at the European level and at the Member State level. However, such a recommendation would allow constitutional and democratic considerations to be ignored too easily.

A fundamental question is which executive actors the Parliament actually should hold to account. In view of its direct democratic legitimacy at the European level, it is reasonable to assume that the European Parliament is the principal actor that should hold actors with executive powers at the European level (such as the Commission and EU agencies) to political account. However, the situation is somewhat different concerning executive actors at the national level, notably national governments. They are first and foremost accountable to 'their' respective national parliaments. It follows that the European Parliament should not be overambitious when it comes to holding them to account. Rather it should engage the principal forums - the national parliaments - in this respect if it wishes to hold national authorities to account. The powers of inquiry vis-à-vis executive actors at the national level thus should not be amended radically.

929 Hix (2005), p. 32. 
The situation is different for the legal position of committees of inquiry vis-àvis executive actors at the European level. The de jure weak position of committees of inquiry vis-à-vis these executive actors should be strengthened. On the basis of the book's findings, the following recommendations can be made regarding the right of inquiry.

\section{Subjudice rule}

Article 226 TFEU stipulates that committees of inquiry may not investigate 'alleged facts' which are being examined by a court at the Member State level or at the EU level. This broadly formulated sub judice rule has the potential to paralyse the right of inquiry. A simple claim for damages before a national court regarding 'alleged facts' may frustrate the establishment of a committee of inquiry on these 'alleged facts'.

A fair balance should be struck between, on the one hand, the rationale of the sub judice rule (the doctrine of the separation of powers) and the ability of the Parliament to hold an inquiry into alleged abuses in the EU sphere. To this end, the sub judice rule should be redefined in the TFEU. A more balanced wording of the sub judice rule would be: 'Committees of inquiry may not enter into concrete legal questions which are simultaneously being considered by a court of law'. This wording mitigates the risk that the right of inquiry is paralysed too easily, while observing the doctrine of the separation of powers at the same time.

\section{Right of summons}

In order to fulfil its task of holding EU actors to account through inquiries, committees of inquiry should be able to gather evidence from any person working for these actors. Inquiry committees should therefore be given a right to summon any person working directly for the EU at the European level, ranging from members of the Commission, the President of the European Council and the President-in-office of the Council to administrators working for the European Central Bank or EU agencies. It should be noted that the European Ombudsman, who is elected by the Parliament, already has a right of summons vis-à-vis all officials and other servants of EU authorities.

The current provisions governing the invitation of officials and servants of a national Member State, as well as those regulating the invitation of members of national governments, should be extended with a duty to inform committees of inquiry extensively on any reasons for a refusal to appear before it.

\section{Questioning of witnesses}

In order to increase the reliability of evidence given, the right of summons should be combined with the ability for committees of inquiry to swear in witnesses.

The witnesses who have specific inside information on alleged abuses under investigation are generally officials and servants. Access to their information is therefore of vital importance for committees of inquiry. Under the current Interinstitutional Agreement, officials and servants testify on behalf of and as instructed by their governments or institutions. In order to prevent these 
witnesses from concealing relevant information from committees of inquiry, they should be bound to testify on their own authority.

\section{Access to documents}

Executive actors should be discouraged from concealing information from committees of inquiry by issuing a blanket claim that the information is too sensitive to be forwarded. Therefore, arrangements should be made which ensure that committees of inquiry are informed properly of the reasons why information cannot be forwarded to them, without running the risk of making sensitive information, such as state secrets, available to the public.

The President of the European Parliament could be given a mediating role in this respect. If authorities do not want to provide committees of inquiry with information because of its sensitive nature, they should be under a duty to inform the President of the Parliament of the reasons for this. The President of the Parliament may try to find a solution, for example by proposing that the sensitive parts be withheld and the rest forwarded to the committee of inquiry. If the authorities in question insist on concealing the information from the committee of inquiry, the President of the Parliament should verify the correctness of that decision in the light of the provisions on access to documents. The President subsequently informs, without necessarily divulging the grounds for his or her decision, whether or not the Member State in question could rightfully conceal the information from the committee of inquiry.

Furthermore, committees of inquiry can discuss the conditions for treatment of classified information covered by obligations of professional secrecy with the authorities in question in advance. It is, for example, conceivable that an executive actor might forward specific information to a committee of inquiry (or only to some of its members) on the condition that the information remains confidential.

\section{Public proceedings}

With a view to optimizing the public character of inquiries, the current unilateral right of witnesses to testify in camera should be abolished, as it is appropriate to give committees of inquiry, not the witnesses, the final say over the organization of inquiry proceedings.

\section{Fact finding visits}

Although committees of inquiry as a rule undertake on-the-spot fact-finding visits in the course of their inquiries, the current Interinstitutional Agreement on the right of inquiry is silent on this issue. The opportunity for committees of inquiry to conduct fact-finding visits should be provided for explicitly.

\section{Quick access to CJEU}

Committees of inquiry should not only be equipped with extra powers, but there should also be a possibility for them to call on the CJEU directly when they consider that their rights have been infringed. Executive actors should be discouraged from deploying blocking tactics against committees of inquiry, for example by responding slowly to requests for documents. Such blocking tactics 
may hinder the work of committees of inquiry substantially, given the fact that they are generally under the time pressure of their temporary mandate. The CJEU should therefore deal with such requests from committees of inquiry quickly, in order to enable them to conduct their investigations.

\section{Legal protection}

If committees of inquiry are to gain stronger powers vis-à-vis witnesses in the future, the need to lay down explicitly the rights of these witnesses grows. The rights of witnesses, such as the right to legal assistance and the duty to inform witnesses of their rights and obligations, should be laid down explicitly.

Executive actors and (natural and legal) persons under investigation should have the ability to contest directly decisions of committees of inquiry, by submitting a complaint to the Parliament. If the Parliament refuses the objection or fails to take a timely decision, it should be possible to make a direct appeal to the CJEU to request a judgement on the lawfulness of a decision of the committee of inquiry.

\subsection{Beyond formal powers; incentives to investigate and to cooperate}

The parliamentary proposals to equip committees of inquiry with stronger powers are discussed above. According to the rapporteur on this dossier, David Martin (S\&D), these proposals appear "appropriate enough to ensure that the political control exercised by the European Parliament - the only directly elected Union institution - is ultimately serious, efficient and in line with the European citizens' expectations of democratic accountability and good governance". ${ }^{930}$ By making this statement, the rapporteur jumps to conclusions too easily. Although the formal position of committees of inquiry should indeed be strengthened, there is not a one-to-one correlation between the strength of the legal powers to investigate executive action and the degree of success had by parliamentary investigations. Much depends not only on the investigative powers of the European Parliament and its skills in conducting investigations, but also on the incentives for the Parliament to investigate executive action and the incentives for executive actors to cooperate with parliamentary investigations.

Even if the Parliament were to gain every conceivable power to conduct investigations, existing accountability deficits would not be reduced if a parliamentary majority, for whatever reason, did not want to investigate executive action. The highly interwoven nature of governments and coalitional majorities in parliaments at the national level means that many national parliaments in the European Union appear unwilling to critically investigate executive action taken by their respective governments. It generally does not help ambitious parliamentary backbenchers in their political career if they adopt a rather critical attitude vis-à-vis a government in which their political

\footnotetext{
${ }^{930}$ European Parliament (2011). AFCO committee. Report on a proposal for a regulation of the European Parliament on the detailed provisions governing the exercise of the European Parliament's right of inquiry and repealing Decision 95/167/EC, Euratom, ECSC of the European Parliament, the Council and the Commission (A7-0352/2011, 14.10.2011), p. 29.
} 
party is represented. Although party (and national) discipline undeniably plays a role in the behaviour of the European Parliament, this discipline seems less apparent than in national parliaments. The main reasons for this is the lack of a clear link between the EU executive and the European Parliament and the resulting lack of a clear coalition and an opposition within the Parliament. Furthermore, the internal cohesion of the political groups in the Parliament is limited, and the interference of national political parties in the behaviour of their MEPs in the European Parliament is restricted. It thus seems that political groups and Members of the European Parliament have fewer incentives to refrain from investigating executive action than their counterparts at the national level, which self-evidently is a positive precondition from the perspective of accountability at the European level.

This book has shown that executive actors can be held to account if they have proper incentives to account for their actions. Legal obligations on executive actors (such as duties to provide the Parliament with oral and written information) do create such incentives, as it may be assumed that executive actors generally prefer to act in accordance with the law rather than to contravene it. Executive actors thus can be legally compelled to give information, but it is difficult to force them to forward information which is relevant, reliable and complete in practice. After all, how can the Parliament secure specific documents if it is not even aware of their existence? And how can the Parliament be sure that it receives all of the relevant information? In spite of legal obligations to do so, on many occasions (mainly) the Council and Member State authorities provided only limited written documents - or none at all - to committees of the European Parliament. Hence, legal obligations alone do not suffice. It is exactly for this reason that one should not concentrate exclusively on legal provisions when attempting to reinforce the investigative function of the European Parliament. Besides investigative powers, there must be additional incentives to induce executive actors to account for their actions. This book has shown a correlation between the degree of interdependence between the European Parliament and executive actors, and the degree of cooperation that the Parliament enjoys from executive actors in the course of its investigations. The European Commission needs the Parliament if it wants to achieve its goals, and a good relationship with the Parliament is therefore essential. As a rule, the Commission thus displays a cooperative and responsive attitude in its contacts with the Parliament. The Parliament has shown that it does not shy away from putting pressure on the Commission if it deems it necessary. The BSE case provides a good example in this respect, as the Parliament threatened to table a motion of censure against the Commission if the Commission did not follow up on recommendations which had been put forward by a parliamentary committee of inquiry. This threat served to ensure that the Commission indeed followed up on the recommendations made by the Parliament. The strategic use of the motion of censure by the Parliament thus created a strong incentive for the Commission to cooperate with Parliament both during and after its parliamentary investigation. The Parliament has demonstrated a similar strategic use of its powers vis-à-vis EU agencies in the course of the annual discharge procedure. The threat to refuse discharge has 
proved a useful instrument to get a grip on EU agencies and to hold them to account not only for the management of their budget but even beyond budgetary issues and for their performances in general. The Parliament can also put pressure on agencies by holding budget in reserve or by cutting their budgets (or by the mere threat to do so). In its capacity as co-legislator, the Parliament can further press for legislation to restructure agencies, to change their powers and tasks, or even to abolish them.

Things are, however, quite different in the relationship between the European Parliament and the Council and Member States authorities, where it is hard - if not impossible - to speak of a relationship of interdependence and where incentives for the Council and Member States to cooperate are consequently considerably less self-evident. It is inter alia for this reason that it is more difficult for the Parliament to hold them to account for their actions.

Besides the legal obligations and the degree of interdependence with the Parliament described above, there is a third factor which influences the incentives to cooperate in the course of parliamentary investigations, namely public pressure. Wide publicity ensures that executive actors are held to public account and means that executive actors run the risk of suffering a loss of face if they do not cooperate properly in the course of a parliamentary investigation or if they break their promises. The pressure on persons appearing before parliamentary committees to give a true statement is considerably higher if these witnesses know that they are held to public account. The same is true for access to documents, as publicity raises the pressure to forward documents which authorities perhaps initially did not want to release. Furthermore, wide publicity increases the chance that relevant information finds its way from other sources, such as journalists, scientists and whistleblowers, to parliamentary committees. In this sense, publicity may reinforce the Parliament's position vis-à-vis the executive in terms of information, which would make it easier for the Parliament to conduct investigations and would make it more difficult for executive actors to withhold information and to evade the process of account-giving. In comparison with Member States, the European Union lacks its own public sphere and 'European issues' - apart from a few exceptions - still seem to matter little when compared to 'national issues'. Parliamentary inquiries conducted by national parliaments generally attract substantial media coverage. Public hearings held by national committees of inquiry are regularly broadcasted live on national television and form a major item on the TV news, and journalists scrutinize the proceedings of the inquiry committees closely. The situation is quite different at the European level, where the mere existence of a temporary committee of inquiry is generally not known outside Brussels and Strasbourg. Apart from specific exceptions, such as the BSE case in the mid-90s, it thus seems more difficult for the European Parliament than for national parliaments to use publicity as an instrument for putting pressure on executive actors in the course of parliamentary investigations. It follows that the weapon of 'naming and shaming' with regard to executive actors is generally less strong at the European than at the national level. 
The European Parliament has shown that it is able to hold the Commission and $\mathrm{EU}$ agencies to account by means of parliamentary investigations. However, it faced difficulties in holding the Council and Member States authorities to account. It seems the likely ambition of the Parliament to make success stories out of its investigations has led it to focus mainly on the actors it feels it can hold to account. The BSE inquiry is illustrative in this respect. The Commission was called to account on issues for which mainly one Member State (the United Kingdom) and the Council were to blame. Hence, a mismatch arose between who was responsible and who was ultimately held to account. As national parliaments are the appropriate democratic forum for holding their respective national governments to account, it is by all means valid that the European Parliament exerts restraint when it comes to holding national governments (and other national authorities) to account. The situation in respect of the Council is different. Although national parliaments should hold national governments to account for their actions as part of the Council, none of them is able to hold the Council to account, as it is a composition of 27 Member State governments. The Council, as such, should be held to political account by the European Parliament. From this perspective, it is problematic that the Council proved intangible for the European Parliament.

\subsection{Mutual influence between stages of accountability}

The introductory chapter has shown that any process of accountability consists of three stages: the information stage, during which the Parliament collects information from executive actors to gain a thorough picture of the way they have performed their tasks, the debating stage, during which the Parliament debates its findings with these accountability actors and during which accountability actors can explain or justify their performances, and the judgment stage, during which the Parliament can deliberate on possible sanctions (formal or informal) to impose on executive actors. Existing literature tends to present these as three clearly separate stages. This book has however demonstrated that these stages cannot be distinguished clearly from one another.

It has been argued above that much depends on incentives. If the Parliament has the ability to hurt an executive actor, and it is feasible that the Parliament might actually do this, then executive actors have incentives to cooperate in the course of investigations. EU agencies funded from the EU budget are aware that their destiny lies, in part, in the hands of the European Parliament. In the judgement stage of accountability, the Parliament may sanction EU agencies by refusing discharge. This is not a consideration which suddenly comes up within agencies once the first two stages of accountability have been completed. Quite the contrary; agencies are aware of the existence of this Damoclean sword during the two preceding stages of accountability. The mere knowledge the sword might fall provides an incentive to cooperate during the first two stages of accountability. This book has provided similar examples that relate to the Commission, most clearly in the BSE case. The threat of a motion of censure served to ensure the cooperation of the Commission in the course of the parliamentary investigation scrutinizing the implementation of the recommendations put forward by the BSE committee of inquiry. 
It is not only the third stage of accountability which is interwoven with the first two stages, but there is also a link between the first two stages. The mere fact that executive actors are aware that they may have to explain their actions (second stage), may very well influence their willingness to provide the Parliament with relevant information (first stage). Whether sanctions are ultimately imposed on executive actors depends on the events in the two earlier stages.

This book thus has shown that the possibility of punishment, of whatever nature, is a sine qua non for any accountability relationship. If the Parliament has no ability to hurt executive actors, then these executive actors will most probably only have weak incentives to give a proper account of their actions. This explains, to a large extent, the book's findings that the Commission and EU agencies proved more cooperative than the Council and individual Member States in the course of parliamentary investigations.

The influence of single accountability stages on other accountability stages can be shown schematically as follows:

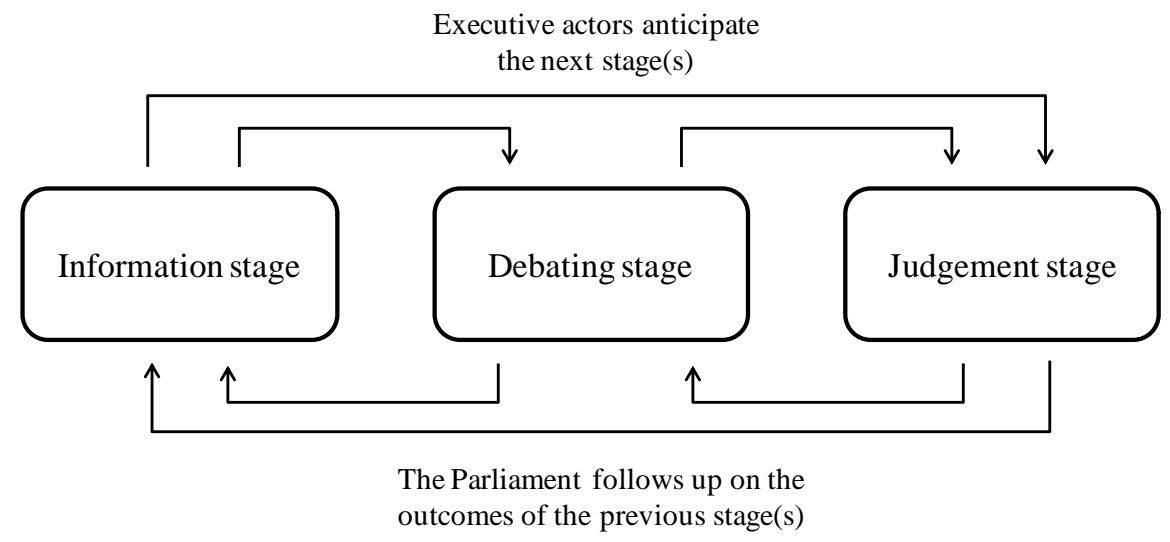

Figure 5.1 Mutual influence and reinforcement of the stages of accountability

\subsection{Strengthening the investigative function of the Parliament}

This book has shown several examples where the Parliament held executive actors to account by means of parliamentary investigations. It has thus been established that parliamentary investigations can be a useful instrument in the European Parliament's accountability toolbox. It must be emphasized that it can be a useful instrument, and not that it necessarily is a useful instrument. A formally strong instrument may be weak if used incorrectly and, conversely, a formally weak instrument may be strong if used in a strategic way. Much depends not only on legal arrangements, but also - perhaps mainly - on the way in which the Parliament makes use of its investigative power. On the basis of the findings, the following recommendations can be made to strengthen the investigative function of the European Parliament. 
Firstly, the powers of committees of inquiry should be strengthened. The current powers of committees of inquiry are laid down in an interinstitutional agreement concluded in 1995. The polity of the European Union and the institutional balance within the European Union has been changed significantly between 1995 and the present. The sphere of activity of the European Union has been extended at the expense of exclusive national authority and within the EU institutional structure the European Parliament has become a mature player. Not only in its legislative task, where it has become a fully fledged colegislator in virtually all fields of activity of the European Union, but also in its scrutiny task, the Parliament has shown that it can no longer be marginalized as a powerless 'talking shop'. However, the 1995 Interinstitutional Agreement on the right of inquiry of the European Parliament still reflects the situation as it was when it was written. Upon its codification in the Maastricht Treaty in 1993, the right of inquiry of the European Parliament was defined as the strongest control power in the armoury of the European Parliament. However, in terms of formal investigative powers, the committees of inquiry of the European Parliament have since been surpassed by the European Ombudsman, who is appointed by the European Parliament. The 1995 Interinstitutional Agreement is thus in need of a revision to bring the European Parliament's right of inquiry up to date with the European Union as it now stands and with the position the European Parliament has acquired within it. The 1995 Interinstitutional Agreement should be revised to give the European Parliament the necessary tools to achieve the very purpose for which the right of inquiry was laid down in the Treaties: holding executive actors in the EU to account. Article 226, third paragraph, TFEU commissions the Parliament explicitly to determine the detailed provisions governing its right of inquiry ('The detailed provisions governing the exercise of the right of inquiry shall be determined by the European Parliament, acting by means of regulations on its own initiative in accordance with a special legislative procedure, after obtaining the consent of the Council and the Commission'). Section 5.2 contains specific recommendations for giving committees of inquiry stronger powers.

\section{The European Parliament should make strategic use of its investigative powers}

The ability of the Parliament to hold executive actors to account in the EU sphere depends not only on legal arrangements, but also (and perhaps mainly) on the way in which the Parliament uses its ability to investigate executive action. This book has shown that when the Parliament uses its investigative powers strategically, it can hold executive actors to account by means of investigations. Making a strategic use of investigative powers means, in short, that (1) the Parliament should identify the right issues (2) to be investigated by the proper committee (3) in an effective manner, and (4) the Parliament should scrutinize the follow-up given to its investigations.

(1) The Parliament should identify the right issues...

Firstly, the Parliament should identify the right matters to investigate. To this end, it should assess critically which matters it wants to investigate and which not. Although it might be understandable that the Parliament is tempted to 
investigate any matter it deems important, it is advisable that it investigates issues which fall within the competence of the European Parliament. In particular, the investigations into Equitable Life and the CIA flights have shown that the more the Parliament departs from its sphere of competence, the more resistance it encounters in the course of its investigations. In addition, investigative activities outside the sphere of competence of the Parliament have little prospect of success when it comes to the follow-up phase, as Parliament, ipso facto, has no say in that. Recommendations put forward the Parliament on matters which fall outside its own sphere of competence are thus likely to be ignored by the authorities to which they are directed. ... to be investigated by the proper committee...

Secondly, the Parliament should choose the appropriate type of committee to investigate issues which fall within its sphere of competence. The bulk of the Parliament's work is done by its standing committees, which is also true for parliamentary investigations. Standing committees are indispensable for the investigative activities of the European Parliament as they can investigate issues which fall outside the scope of the right of inquiry and/or for which there is no majority support to establish a temporary committee. Temporary committees mainly concentrate ex post on specific past incidents on an ad-hoc basis. They pass a judgement and they put forward recommendations for the future. Thereupon the temporary committee ceases to exist and the scrutiny of the follow-up activities lies in the hands of the standing committees. Standing committees are more concerned than temporary committees with executive action on a continuous basis. The discharge procedure in particular shows that the Parliament's scrutiny activities are not only of an ex post nature, but also 'ongoing' and ex ante. The discharge decision generally goes further than merely giving (ex post) an approval or a refusal for the handling of the budget in a preceding financial year. It also contains ex ante recommendations for the future, and the Parliament scrutinizes the follow-up to these recommendations in an ongoing manner. In this context, ex ante, ex post and ongoing scrutiny mutually influence and reinforce one another. The strength of this scrutiny lies mainly in its continuous nature and the degree of specialization, which are generally better safeguarded in the standing committees than the temporary committees.

There are, however, situations where it is advisable to establish a temporary committee to conduct a specific investigation. This is the case, for example, when an issue is too important or too comprehensive to be left to the standing committees, which are generally already overloaded. Temporary committees have the advantage that they bring together MEPs from several standing committees with specific knowledge of the issue under investigation. The establishment of a temporary committee further prevents disputes as to which standing committee should deal with a given issue. One could say that if an issue is not being dealt with by a temporary committee, it will not be possible to really deal with it in-depth. Additionally, there is an agenda-setting argument. Establishing a temporary committee guarantees that the spotlight is put on a specific issue and that the issue appears not only on the committee agenda, but also on the plenary agenda and in all probability even on agendas 
outside the Parliament. The investigations into Echelon and CIA flights have proved to be consciousness-raising exercises in which special committees managed to bring alarming issues to light which were as good as unknown to the public before Parliament put the spotlight on them. This is particularly striking given the fact that these issues fell outside the sphere of competence of the Parliament. It is highly doubtful whether these issues would have attracted similar attention had they been examined by standing committees.

Temporary committees of inquiry have more investigative powers than temporary special committees. Therefore they are more usefully employed in cases where the Parliament needs to collect evidence from executive actors and where it is likely that this evidence will not be given on a voluntary basis. Temporary special committees are particularly useful because they provide a middle-course in situations where setting up a committee of inquiry would be a disproportionately strong action, but where the Parliament nonetheless wants to establish a temporary committee to investigate one specific issue in depth. Moreover, setting up a special committee is useful if the restricted scope of the right of inquiry prohibits the establishment of a committee of inquiry. Another advantage is more political in nature. The use of the right of inquiry, the strongest control power of the Parliament, may be controversial within the Parliament and the establishment of a committee of inquiry therefore runs the risk that those political groups which initially reject the establishment of an inquiry committee frustrate its work if such a committee is nonetheless set up.

It is advisable that the Parliament make prudent use of temporary committees, as using them too frequently may reduce their impact. In general, it can be said that the use of an extraordinary instrument requires an extraordinary reason. The conduct of a parliamentary investigation, in itself, is a time consuming event, which thus should only be initiated if a matter of public concern needs to be clarified. As a general standard, it can be said that general matters of public concern should be dealt with by standing committees and that matters of extraordinary public concern should be investigated by temporary committees, whereby the standard should be higher for committees of inquiry than for special committees.

\section{(3)} ...in an effective manner...

Thirdly, executive actors should be held to account effectively. That is to say, the Parliament should get to the bottom of the matter under investigation to prevent executive actors from evading accountability. Executive actors should be required to give account for their actions and, where appropriate, they should suffer consequences and/or put matters right if it appears that errors have been made. Holding executive actors to account effectively requires the Parliament to inform itself thoroughly on the matter under investigation. It should therefore endeavour to obtain relevant information from the executive actors involved and it should be willing to benefit from the knowledge of other actors, such as national parliaments, the EU Ombudsman, national ombudsmen, the European Court of Auditors, national courts of auditors, NGOs, academics and other experts. The Parliament should also make strategic use of the publicity given to investigations, which means that the Parliament should actively seek media coverage under certain circumstances. 
Wide publicity can be useful as it may raise the pressure on executive actors to inform the Parliament fully and accurately. Wide publicity further increases the chance that relevant information reaches the Parliament without an explicit request, for example through well-informed academics, journalists or whistleblowers.

The investigation should ultimately lead to a final report in which the Parliament establishes the conduct of one or more executive actors. Such a report should, however, go further than that. If abuses have been identified, the report should also contain recommendations to prevent such abuses in the future. It is, however, not self-evident that the Parliament's recommendations are automatically followed-up on by the competent actors. To that end, the final report should be a solid and credible document which reflects the findings of a meticulous investigation. A biased, one-sided report weakens its credibility and legitimacy and thus makes it easier to be ignored. Moreover, it is of vital importance that the final report be adopted by a large majority in the Parliament, as a 'coincidental' majority does not suffice if the Parliament really wants to achieve something. Only an overwhelming majority will be taken seriously by the Commission and the Council. From this perspective, a compromise with great support may be more likely to fall on fertile ground than a pronounced recommendation supported by only a narrow majority.

(4) ... and the Parliament should scrutinize the follow-up given to its investigations.

Lastly, the Parliament should closely scrutinize the follow-up given to a final report by executive actors. It should make sure that executive actors do not only promise improvements, but that they also live up to their promises in practice. This book has shown some clear examples of situations where the Parliament closely scrutinized the follow-up to an investigation. In the BSE case, the Parliament set up a special committee directly after the committee of inquiry into BSE ceased to exist. The sole task of the special committee was to scrutinize the extent to which the Commission had followed up on the recommendations put forward by the committee of inquiry. The special committee's close scrutiny made it nearly impossible for the Commission to ignore the parliamentary recommendations. A similar pattern has been witnessed with regard to $\mathrm{EU}$ agencies in the context of the discharge procedure, where agencies cannot simply ignore parliamentary recommendations, as it is plausible that the Parliament will scrutinize the follow-up in the following year's annual discharge procedure. Whereas Section 5.4 demonstrates that single stages within one accountability process mutually influence and reinforce one another, it can be added that the same is true for subsequent accountability processes. A parliamentary committee which builds on earlier investigative work can take advantage of both the findings of the earlier investigations and it can scrutinize whether executive actors have lived up to the promises they made. The mere knowledge that the Parliament will not be satisfied with only promises, but that it will also scrutinize on a later occasion whether these promises have translated into actions, may further induce executive actors to keep their promises. The executive actors will anticipate future parliamentary investigations in which they will be held to account for the follow-up given to a previous investigation on the same subject. 
If the Parliament does not scrutinize the follow-up given to its investigations, it may be tempting for executive actors to 'forget' their promises made when a specific issue was still important to the Parliament. Ongoing scrutiny activities are thus needed to prevent executive actors from evading accountability. The way in which subsequent parliamentary investigations may strengthen each other can be shown schematically as follows:

\section{Executive actors anticipate future investigations}

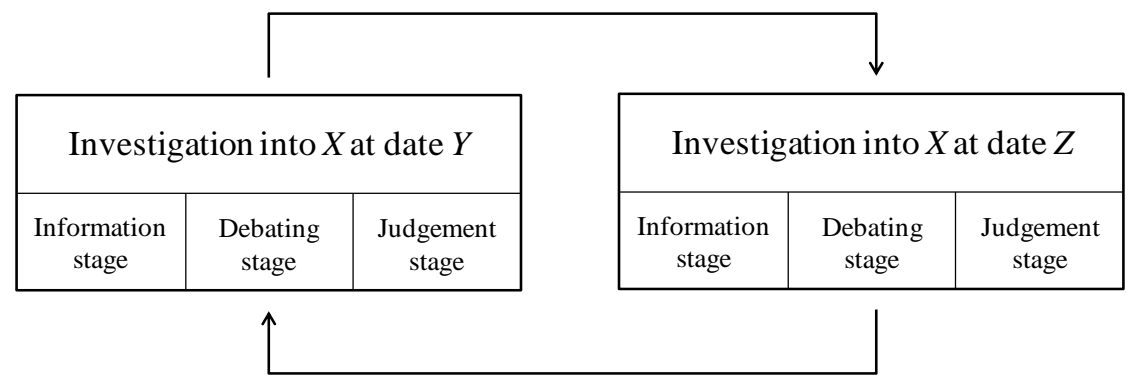

The Parliament follows up on previous investigations

Figure 5.2 Reinforcing accountability through ongoing investigative activities

\subsection{Outlook}

Standing committees have proved able to fulfill the task of investigating executive action on an ongoing and systematic basis. The temporary committees have proved useful tools for the in-depth investigation of issues of public concern which go beyond the 'general' agenda of the European Parliament. This book has given examples of the European Parliament's ability to hold the Commission to account for its actions through parliamentary investigations. The Parliament has managed to do this through a strategic use of its investigative powers and the creative deployment of its other instruments, such as its budgetary powers and the (threat of a) motion of censure, in the course of its investigations. The Parliament has further shown that it is able to use its budgetary authority to hold EU agencies to account. These findings may be welcomed from the perspective of accountability. Even though the Commission thus seems to be an accountable institution according to some even the most controlled executive in the world ${ }^{931}$-, the 'bureaucratic' Commission still appears to be unaccountable to European citizens. This 'accountability paradox'932, as Wille claims, can be remedied by personalizing the politics of the Commission by linking its nomination directly to the result of the European elections. ${ }^{933}$ This suggestion can be welcomed

\footnotetext{
${ }^{931}$ Lord (2004).

932 Wille (2010), pp. 84-86.

933 Ibid. pp. 85-86.
} 
from a democratic perspective, as it implies a direct democratic chain of delegation from the European citizens via the European Parliament to the Commission. However, it may endanger the constitutional perspective of accountability by facilitating executive dominance. Linking the nomination of the Commission directly to the outcome of European elections would probably, as in many Member States, result in a parliamentary coalition supporting the Commission on the one hand and a parliamentary opposition on the other. As discussed earlier, the highly interwoven nature of governments and coalitional majorities in parliaments at the national level means in practice that many national parliaments in the European Union appear unwilling to critically investigate executive action taken by their respective governments. The overall conclusion that it would be desirable, from an accountability perspective, to link the nomination of the Commission directly to the European elections therefore seems rather hasty.

When it comes to holding the Council and Member States to account for their actions by means of parliamentary investigations, the picture is less optimistic. The interdependence of the Parliament on the one hand, and the Commission and $\mathrm{EU}$ agencies on the other, ensures a high degree of responsiveness from the Commission and the EU agencies in their dealings with the European Parliament. Such an interdependence hardly exists (if at all) between the Parliament and both the Council and individual Member States. Consequently, the Council and individual Member States are less incentivized to give a proper account of their actions.

In its capacity as the only directly elected body, the European Parliament is an important political accountability forum at the European level. It follows that the European Parliament is the appropriate body to hold executive actors at the European level to account. This book has, however, shown several examples where the Parliament has attempted to hold Member State governments directly to account. The parliamentary proposals to equip committees of inquiry with strong powers vis-à-vis Member State authorities further shows the Parliament's eagerness to hold Member States to account for their actions in the future. It is, however, doubtful whether the European Parliament is the most appropriate forum to do this. As national governments are created, be it directly or indirectly, via national parliamentary elections, it follows that they are in the first place politically accountable to 'their' respective national parliaments. Notions such as multilevelness and subsidiarity not only describe and set the norm regarding the exercise of executive functions, they apply mutatis mutandis to the European Parliament. In spite of its great ambitions, the European Parliament should firstly recognize that where there is multilevel governance, there should be multilevel accountability, and, secondly, that executive actors should be held to account at the most appropriate level.

This does not mean that the European Parliament should not keep an eye on the way European law is implemented at the national level. On the contrary, Article 226 TFEU mandates committees of inquiry to investigate alleged abuses in the EU sphere, including abuses allegedly perpetrated by Member State authorities. The subsidiarity considerations mentioned above imply rather that the European Parliament should exert restraint when holding 
national authorities to account directly. It follows that if the European Parliament deems it appropriate to hold a national authority to account, it should in the first place encourage the national parliament to take the appropriate action. One can also imagine a situation where the European Parliament and national parliaments act in combination to hold national authorities to account. It is, however, conceivable that national parliaments are not always willing to hold 'their' respective governments to account. In such cases, it is fully legitimate for the European Parliament to make an attempt to hold the national authority to account by itself. The Parliament can also bring alleged abuses at the national level to the attention of the European Council, the Council, and the Commission. Thereupon, these institutions can take action to hold the national authorities to account. The European Council, for example, can place the alleged abuse on its agenda, and the Commission can request a Member State submit its observations regarding an alleged abuse, possibly leading to infringement proceedings against the Member State in question. These considerations can be shown schematically as follows:

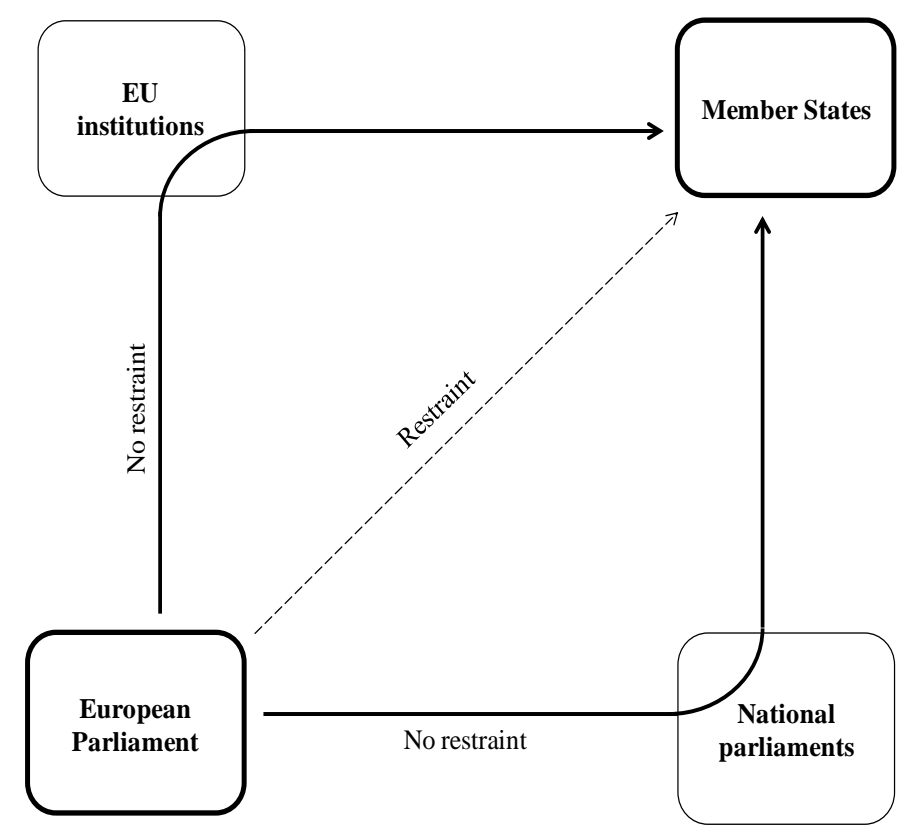

Figure 5.3 Holding Member State authorities to account directly or via other actors

The Council, as a composition of 27 Member State governments, can only be held to account for its actions at the European level. The finding that the European Parliament faces difficulties in its attempts to get a grip on the Council is therefore more problematic. The question, however, is how the Parliament can hold the Council to account for its actions. The fact that the presidency of the Council rotates every six months does not only have 
implications for its degree of continuity, but also makes it difficult for the Parliament to establish a fruitful accountability relationship with the Council. In order to prevent 'accountability gaps', the European Parliament should involve its national counterparts in holding the apparently untouchable Council to account. In the words of Bovens et al., "it is not possible to get to grips with and hold complex multilevel and multifaceted actors to account without having a combination of political forums at both national and supranational levels". 934 Therefore, 'networks of accountability' should be established to exchange information and enable cooperation between the European Parliament and national parliaments. Harlow and Rawlings have made valuable suggestions in this regard. For them, a network of accountability is a network of agencies specialising in a specific method of accountability, such as investigation, adjudication or audit, which come together or coalesce in a relationship of mutual support, fortified by shared professional expertise and ethos. ${ }^{935}$ The proper functioning of such a network would require a sense of a common purpose among the individual players within the network. The common objective of the European Parliament and the national parliaments should be to hold the Council to account for the exercise of its executive powers. However, mainly at the national level but also at the European level, executive dominance over parliaments may represent a threat to the proper functioning of such a network.

The Treaty of Lisbon weakened the position of the Council, but formalized and strengthened the position of another representative of the EU Member States, namely the European Council. The problem of the apparently intangible Council thus seems to have been replaced in part by the challenge of having to hold the European Council to account for its actions as well. It still remains to be seen how the position of the European Council and its President evolve in the institutional framework of the European Union. However, the fact that the President of the European Council is appointed for a term of two and a half years (renewable once), may offer the European Parliament an opportunity to build up an accountability relationship with the European Council. A formal framework agreement defining information and consultation mechanisms between the European Parliament and the European Council would be a step in the right direction. However, just as the Council cannot be held to account by either the European Parliament or national parliaments acting alone, the European Council should be held accountable for its actions both at the European level (the President of the European Council) and at the national level (the individual heads of state or government as members of the European Council). Despite positive developments ${ }^{936}$, the absence of formal powers to penalize the European Council means it remains highly questionable whether a fruitful accountability relationship will develop between the European Parliament and the European Council. It thus remains mainly for the national parliaments to hold the European Council to account by closely scrutinizing

\footnotetext{
${ }_{934}$ Bovens/Curtin/'t Hart (2010b), p. 194.

935 Harlow/Rawlings (2007), p. 546.

${ }^{936}$ Cf. Van de Steeg (2010), p. 143.
} 
the actions of their respective members in the context of the European Council's activities. 


\section{SAMENVATTING}

Het Europees Parlement heeft zich in de afgelopen decennia ontwikkeld van een tandenloos adviesorgaan, bestaande uit nationale parlementariërs, tot een zelfstandig en volwassen parlement met rechtstreekse democratische legitimatie. Die transformatie is het duidelijkst zichtbaar voor wat betreft zijn wetgevende functie. Sinds de recente inwerkingtreding van het Verdrag van Lissabon heeft het Europees Parlement een beslissende stem met betrekking tot de meeste Europese wetgeving. Wellicht minder zichtbaar, maar daarom niet noodzakelijk minder belangrijk, is de toegenomen betekenis van het Europees Parlement als controleur van de macht die wordt uitgeoefend in EU verband. Door de voortschrijdende Europese integratie zijn steeds meer uitvoerende bevoegdheden overgeheveld van het nationale naar het Europese niveau. In de wetenschappelijke literatuur wordt er in dit verband op gewezen dat de toename van uitvoerende bevoegdheden op Europees niveau niet is samengegaan met een gelijkwaardige toename van democratische controle op de uitoefening van die bevoegdheden. Daardoor zou de Europese Unie te kampen hebben met een verantwoordingstekort, waarmee wordt bedoeld dat er in Europees verband onvoldoende verantwoording wordt afgelegd over uitvoerend handelen. Als enige rechtstreeks gekozen instelling op Europees niveau heeft het Europees Parlement de belangrijke taak om de uitvoerende organen, zoals de Europese Commissie, maar bijvoorbeeld ook de Raad van de Europese Unie, de Europese Raad, nationale lidstaten en Europese agentschappen, ter verantwoording te roepen voor hun handelen. Het Europees Parlement kan op verschillende manieren invulling geven aan zijn controletaak. Daarbij kan worden gedacht aan het stellen van parlementaire vragen aan deze organen, het houden van debatten met hen en het verrichten van parlementair onderzoek naar hun handelen. In dit proefschrift staat het onderzoeksrecht van het Europees Parlement centraal. De hoofdvraag is of het huidige onderzoeksrecht van het Europees Parlement voldoet als instrument om uitvoerende organen ter verantwoording te roepen. Daartoe wordt onderzocht welke onderzoeksbevoegdheden het Europees Parlement heeft en hoe het deze in de praktijk gebruikt.

Parlementaire onderzoeken worden niet verricht door het Europees Parlement als geheel, maar door zijn parlementaire commissies: de tijdelijke enquêtecommissies, de tijdelijke onderzoekscommissies en de vaste commissies. Aan de onderzoeksactiviteiten van ieder type commissie wijdt het proefschrift een hoofdstuk.

\section{Parlementair onderzoek door tijdelijke enquêtecommissies}

Sinds de inwerkingtreding van het Verdrag van Maastricht beschikt het Europees Parlement, net als vele nationale parlementen, over het recht van enquête. Het recht van enquête is specifiek bedoeld als instrument om parlementaire onderzoeken te verrichten. Het Europees Parlement kan op basis van artikel 226 van het Verdrag betreffende de werking van de Europese Unie (VwEU) tijdelijke enquêtecommissies instellen om 'vermeende inbreuken op het recht van de Unie of gevallen van wanbeheer bij de toepassing van het recht van de Unie' te onderzoeken. Een belangrijk verschil tussen tijdelijke 
enquêtecommissies en andere parlementaire commissies is dat de tijdelijke enquêtecommissies beschikken over specifieke enquêtebevoegdheden. Deze bevoegdheden, die onder meer betrekking hebben op het horen van getuigen en het opvragen van documenten, zijn in 1995 door het Europees Parlement, de Raad en de Commissie neergelegd in een interinstitutioneel akkoord. De tamelijk zwakke enquêtebevoegdheden, vooral ten aanzien van nationale autoriteiten, laten zien dat de Raad bij die onderhandelingen aan het langste eind heeft getrokken.

Het Europees Parlement heeft sinds 1993 drie enquêtecommissies ingesteld. In 1996-1997 werden twee enquêtes gehouden; een over vermeende fraude in het communautair douanevervoer en de tweede, die meer stof heeft doen opwaaien, over de BSE-crisis. De derde tijdelijke enquêtecommissie, die onderzoek deed naar de ondergang van de Britse levensverzekeraar Equitable Life, werd ingesteld in 2007. Hoewel de drie enquêtecommissies hinder ondervonden van hun bescheiden enquêtebevoegdheden, wisten zij veel boven tafel te krijgen en veranderingen af te dwingen. Vooral de BSE-enquête heeft laten zien hoe het Europees Parlement door een zorgvuldige werkwijze en handig gebruik van andere bevoegdheden het gebrek aan sterke enquêtebevoegdheden heeft kunnen compenseren. Een gedegen onderzoek resulteerde in een breed gedragen rapport met heldere conclusies en een zestigtal aanbevelingen aan de Europese Commissie. Om te voorkomen dat de aanbevelingen genegeerd zouden worden, stelde het Europees Parlement een tijdelijke commissie in die als enige taak had om toe te zien op de vervolgstappen van de Commissie. Daarbij gaf het Parlement de Commissie te verstaan dat het een motie van wantrouwen tegen de Commissie zou aannemen als de Commissie niet binnen een periode van zes maanden na de enquête een positief gevolg zou hebben gegeven aan de zestig aanbevelingen. Dat dreigement bleek effectief; het bewoog de Commissie tot ingrijpende wijzigingen op het gebied van landbouw en volksgezondheid.

De contacten met de Raad van de Europese Unie en de lidstaten verliepen moeizamer. Bij ontbreken van sterke drukmiddelen tegenover deze actoren moest het Europees Parlement lijdzaam toezien hoe er niet altijd gehoor werd gegeven aan verzoeken om te getuigen of om documenten te overleggen en hoe de aanbevelingen van de enquêtecommissies regelmatig werden genegeerd.

De drie enquêtes lieten zien dat de organen die de meeste verantwoordelijkheid droegen voor ontstane misstanden niet vanzelfsprekend de organen waren die het meest nadrukkelijk ter verantwoording werden geroepen. Waarschijnlijk ingegeven door het streven om de enquêtes succesvol te laten zijn, richtten de tijdelijke enquêtecommissies zich namelijk vooral op de Commissie, zelfs als misstanden in hogere mate aan de Raad of aan afzonderlijke lidstaten konden worden toegeschreven.

\section{Parlementair onderzoek door tijdelijke onderzoekscommissies}

Vaker dan van het recht van enquête, maakt het Europees Parlement gebruik van de mogelijkheid om tijdelijke onderzoekscommissies (niet zijnde tijdelijke enquêtecommissies) in te stellen. Veel van de tijdelijke onderzoekscommissies verrichten parlementaire onderzoeken die - vanwege hun gelijkenis met enquêtes - het best omschreven worden als quasi-enquêtes. Tijdelijke 
onderzoekscommissies beschikken niet over enquêtebevoegdheden. Daar staat echter tegenover dat zij niet zijn gebonden aan de beperkte reikwijdte van de enquêtebevoegdheid, die zich slechts uitstrekt tot onderzoeken naar 'vermeende inbreuken op het recht van de Unie of gevallen van wanbeheer bij de toepassing van het recht van de Unie' die bovendien niet gelijktijdig voorwerp zijn van een gerechtelijke procedure.

De parlementaire onderzoeken verricht door tijdelijke onderzoekscommissies laten een met de tijdelijke enquêtecommissies vergelijkbaar beeld zien: meer medewerking van de Commissie dan van de Raad van de Europese Unie en de lidstaten. Daarbij moet worden aangetekend dat tijdelijke onderzoekscommissies onderzoeken hebben verricht naar vermeende misstanden die zich afspeelden op het terrein van de intergouvernementele pijlers van de Europese Unie, waarover de bevoegdheden van het Europees Parlement zich niet uitstrekken. Zouden de Raad en de lidstaten toch medewerking hebben verleend aan de parlementaire onderzoeken op die terreinen, bijvoorbeeld met betrekking tot het veronderstelde gebruik door de CIA van Europese landen voor het vervoer en illegaal vasthouden van gevangenen, dan zouden zij daarmee impliciet de competentie van het Europees Parlement op die terreinen hebben erkend.

\section{Parlementair onderzoek door vaste commissies}

Het leeuwendeel van het parlementaire werk wordt verricht door de vaste commissies van het Europees Parlement. Hoewel de meeste van deze commissies zich hoofdzakelijk concentreren op de beoordeling van wetsvoorstellen, verrichten zij ook parlementair onderzoek. De onderzoeken verricht door vaste commissies variëren van enquêteachtige onderzoeken, waarin vermeende misstanden - al dan niet naar aanleiding van binnengekomen petities - worden onderzocht tot onderzoeken naar de implementatie van wetgeving en onderzoeken in het kader van de jaarlijkse kwijtingprocedure. Laatstgenoemde procedure wordt door het Parlement niet alleen benut om zoals wettelijk voorgeschreven - de uitvoering van de begroting achteraf te beoordelen, maar ook om het gevoerde beleid in bredere zin onder de loep te nemen en aanbevelingen te formuleren voor toekomstig te voeren beleid. Wordt er vervolgens niets met die aanbevelingen gedaan, dan kan het Europees Parlement de goedkeuring van de begroting in het volgende jaar weigeren. Met name Europese agentschappen blijken gevoelig voor deze druk, waardoor het Europees Parlement zijn invloed over het beleid van deze agentschappen kan doen gelden.

\section{Drie typen commissies vergeleken}

Het is van de omstandigheden van het geval afhankelijk welk type commissie het meest geschikt is om een parlementair onderzoek te verrichten. De 'zwaarste' commissies, de enquêtecommissies, hebben de sterkste bevoegdheden en zij zijn om die reden vooral bruikbaar om grootschalige onderwerpen te onderzoeken waarbij het voorzienbaar is dat niet op vrijwillige basis medewerking aan die onderzoeken zal worden verleend. Tijdelijke onderzoekscommissies zijn vooral bruikbaar als middenweg tussen de 'zware' enquête en het vaak kleinschaliger onderzoek door vaste commissies. 
Bovendien hebben tijdelijke onderzoekscommissies een ruime reikwijdte, waardoor zij kunnen worden ingesteld als het houden van een enquête door de beperkte reikwijdte van artikel $226 \mathrm{VwEU}$ niet mogelijk is. Voorts is het instellen van een tijdelijke onderzoekscommissie een praktische compromisoptie als er bij een deel van het Europees Parlement felle weerstand bestaat tegen het instellen van enquêtecommissie.

In vergelijking met de vaste commissies hebben de twee typen tijdelijke commissies als voordeel dat zij zijn samengesteld uit leden van verschillende vaste commissies van het Europees Parlement die beschikken over specifieke kennis met betrekking tot het voorwerp van onderzoek. Het instellen van een tijdelijke commissie voorkomt bovendien gesteggel over de vraag welke vaste commissie het meest geschikt is om een bepaald onderwerp te onderzoeken. Daar komt bij dat tijdelijke commissies de vaste commissies ontlasten, die vaak toch al zijn overladen met werk en dus geen tijd hebben voor diepgaande onderzoeken. De instelling van een tijdelijke commissie garandeert, ten slotte, dat een onderwerp niet alleen hoog op de agenda van een parlementaire commissie, maar ook hoog op de plenaire agenda en op agenda's buiten het Europees Parlement komt te staan.

Ondanks deze voordelen van tijdelijke commissies zijn vaste commissies onmisbaar voor de onderzoeksfunctie van het Europees Parlement. Allereerst omdat tijdelijke commissies onderzoeken kunnen verrichten die buiten de reikwijdte van het enquêterecht vallen en zij onderwerpen kunnen onderzoeken ten aanzien waarvan geen parlementaire meerderheid gevonden kan worden voor het instellen van een tijdelijke commissie. Voor tijdelijke commissies geldt bovendien dat zij ophouden te bestaan nadat zij hun eindrapport hebben afgerond. Daarin schuilt het gevaar dat vervolgens niemand zich geroepen voelt om na te gaan of er ook daadwerkelijk iets met dat eindrapport gebeurt. Vaste commissies kunnen daarentegen een constante vinger aan de pols houden, waardoor effectieve controle na een parlementair onderzoek beter gewaarborgd is. Ook specialiseren vaste commissies zich en bouwen zij een collectief geheugen op, waardoor uitvoerende organen minder eenvoudig kunnen ontsnappen aan het afleggen van verantwoording.

\section{Conclusie}

Het proefschrift concludeert dat de betrekkelijk zwakke enquêtebevoegdheden, die sinds 1995 ongewijzigd zijn, versterkt zouden moeten worden. Daartoe doet het proefschrift concrete voorstellen en plaatst het die tegen de achtergrond van de voorstellen die het Europees Parlement recentelijk zelf heeft gedaan.

De kracht van de onderzoeksfunctie is echter niet alleen afhankelijk van de onderzoeksbevoegdheden die het Europees Parlement tot zijn beschikking heeft. Sterke onderzoeksbevoegdheden helpen immers weinig als parlementen niet bereid zijn ze te gebruiken. Terwijl door monistische verhoudingen de bereidheid van nationale parlementen om nationale regeringen ter verantwoording te roepen vaak ontbreekt, is dat in mindere mate het geval bij het Europees Parlement, dat zich overwegend dualistisch verhoudt tot uitvoerende organen. Bovendien garanderen sterke onderzoeksbevoegdheden niet dat de uitvoerende organen die ter verantwoording worden geroepen ook 
daadwerkelijk medewerking verlenen aan parlementaire onderzoeken. De enkele bevoegdheid om een getuige te dagvaarden en onder ede te horen verzekert immers nog niet dat die getuige alle voor het parlement relevante informatie zal prijsgeven. Evenmin is met een sterke bevoegdheid om documenten op te vragen veiliggesteld dat elk relevant document de parlementaire onderzoekscommissie ook daadwerkelijk bereikt. Om uitvoerende organen ertoe te bewegen verantwoording af te leggen over hun handelen of nalaten is er dus meer nodig dan alleen sterke onderzoeksbevoegdheden.

Allereerst moet het Europees Parlement een serieus tegenwicht kunnen bieden aan de uitvoerende organen die het ter verantwoording roept. Dat veronderstelt niet alleen dat het Europees Parlement tegenover de doorgaans beter geïnformeerde uitvoerende organen moet beschikken over voldoende dossierkennis, maar ook dat parlementaire onderzoeken niet worden gefrustreerd door politieke tegenstellingen binnen het Parlement. Dit proefschrift laat zien dat de onderzoeken van het Europees Parlement zelden worden gegijzeld door interne politieke conflicten en dat onderzoekscommissies door middel van zorgvuldig onderzoek doorgaans tot een gedegen en breed gedragen eindrapport komen. Het belang hiervan mag niet worden onderschat, omdat een ongeloofwaardig en niet breed gedragen eindrapport eenvoudig kan worden genegeerd door uitvoerende organen.

Voorts kan het gebrek aan sterke onderzoeksbevoegdheden worden gecompenseerd door op handige wijze gebruik te maken van andere parlementaire bevoegdheden. Dit proefschrift toont voorbeelden waarin de dreiging met een wantrouwensvotum en de dreiging met budgettaire consequenties effectieve drukmiddelen bleken om de Europese Commissie, respectievelijk Europese agentschappen, ter verantwoording te roepen.

Het Europees Parlement kan uitvoerende organen bovendien ertoe bewegen om verantwoording af te leggen door ruchtbaarheid te geven aan zijn onderzoeken. Op die manier worden uitvoerende organen door een breder publiek dan alleen door de leden van het Europees Parlement ter verantwoording geroepen. Naarmate een parlementair onderzoek meer in de schijnwerpers staat, is het voor uitvoerende organen lastiger om te ontsnappen aan het afleggen van verantwoording. Bovendien zullen journalisten, wetenschappers, NGO's, klokkenluiders en andere personen en organisaties met relevante informatie eenvoudiger hun weg naar het Europees Parlement weten te vinden als zij op de hoogte zijn van een lopend parlementair onderzoek. Door het ontbreken van een Europese 'public sphere' valt het echter niet mee om parlementaire onderzoeken breed onder de aandacht te brengen. Waar op nationaal niveau parlementaire enquêtes vaak voorpaginanieuws zijn, is het enkele bestaan van een enquêtecommissie van het Europees Parlement in de regel vrijwel onbekend buiten Brussel en Straatsburg.

Voor effectieve verantwoording is het voorts essentieel dat het Europees Parlement nauwkeurig toeziet op het gevolg dat uitvoerende organen geven aan de conclusies en aanbevelingen van een parlementair onderzoek. Juist nadat het eindrapport is uitgebracht moet het Europees Parlement er intensief 
op toezien dat gedane beloften daadwerkelijk gestand worden gedaan en geconstateerde fouten worden hersteld.

Hoewel dit proefschrift verschillende voorbeelden laat zien waarin de Commissie en Europese agentschappen door het Europees Parlement tot het afleggen van verantwoording worden bewogen, blijkt het lastiger om de Raad van de Europese Unie en nationale regeringen ter verantwoording te roepen. De Europese Raad is nog niet onderwerp geweest van parlementair onderzoek, en dus ook niet van dit proefschrift. Het ligt echter in de lijn der verwachtingen dat het ook lastig zal zijn voor het Europees Parlement om deze instelling ter verantwoording te roepen. Dit proefschrift concludeert dat er een verband bestaat tussen, enerzijds, de mate waarin uitvoerende organen afhankelijk zijn van een goede verstandhouding met het Europees Parlement en, anderzijds, hun bereidwilligheid om verantwoording af te leggen aan het Europees Parlement. De Commissie en de Europese agentschappen zijn in hun dagelijkse functioneren veelal afhankelijk van het Europees Parlement en zij kunnen het zich dus nauwelijks permitteren om medewerking aan parlementaire onderzoeken te weigeren en om eindrapporten van onderzoekscommissies te negeren. Voor de Raad van de Europese Unie, voor nationale regeringen en voor de Europese Raad ligt dit anders. Zij hebben doorgaans niet veel van het Europees Parlement te duchten en kunnen daarom eenvoudiger ontsnappen aan het afleggen van verantwoording. Het resulterende gevaar van verantwoordingstekorten kan deels op nationaal niveau worden ondervangen door de nationale parlementen, die 'hun' nationale regeringen en hun vertegenwoordigers in de Raad van de Europese Unie en de Europese Raad ter verantwoording roepen. Echter, geen enkel nationaal parlement is in staat om de Raad van de Europese Unie en de Europese Raad als geheel ter verantwoording te roepen. Hier is aldus de schone taak weggelegd voor het Europees Parlement om verantwoordingstekorten te verkleinen en te voorkomen door zowel de interinstitutionele contacten met de Europese Raad en de Raad van de Europese Unie, als de contacten met nationale parlementen te intensiveren. 


\section{BIBLIOGRAPHY}

Arnull/Wincott (2002)

Arnull, A. and D. Wincott (2002). Accountability and legitimacy in the European Union. Oxford etc., Oxford University Press.

Aucoin/Heintzman (2000)

Aucoin, P. and R. Heintzman (2000). 'The dialectics of accountability for performance in public management reform.' International Review of Administrative Sciences 66: 45-55.

Beckedorf (1997)

Beckedorf, I. (1997). 'Das Untersuchungsrecht des Europäischen Parlaments. Eine erste Bestandsaufnahme nach zwei parlamentarischen Untersuchungen.' Europa Recht 3: 237-260.

Beckedorf (1995)

Beckedorf, I. (1995). Das Untersuchungsrecht des Europäischen Parlaments. Berlin, Duncker \& Humblot.

Berner (2004)

Berner, A. (2004). Die Untersuchungsbefugnisse des Europäischen Amtes für Betrugsbekämpfung (OLAF) gegenüber dem Europäischen Parlament: gleichzeitig eine Auseinandersetzung mit dem Rechtsinstitut der europäischen parlamentarischen Immunität. Frankfurt am Main etc., Lang.

Bovens/Curtin/'t Hart (2010a)

Bovens, M. A. P., D. M. Curtin, P. 't Hart (2010). Studying the Real World of EU Accountability: Framework and Design. The Real World of EU Accountability. What Deficit? M. A. P. Bovens, D. M. Curtin and P. 't Hart. Oxford; New York, Oxford University Press: 31-62.

Bovens/Curtin/'t Hart (2010b)

Bovens, M. A. P., D. M. Curtin, P. 't Hart (2010). The Real World of EU Accountability: Comparisons and Conclusions. The Real World of EU Accountability. What Deficit? M. A. P. Bovens, D. M. Curtin and P. 't Hart. Oxford; New York, Oxford University Press: 174-197.

Bovens/Schillemans/'t Hart (2008)

Bovens, M. A. P., T. Schillemans, P. 't Hart (2008). 'Does Public Accountability Work? An Assessment Tool.' Public Administration 86(1): 225-242.

Bovens (2007)

Bovens, M. A. P. (2007). 'Analysing and Assessing Public Accountability. A Conceptual Framework.' European Law Journal 13(4): 447-468. 
Brunsden (2008)

Brunsden, J. (2008). Socialist opposition casts doubt on CIA follow-up. European Voice.

Busuioc (2010a)

Busuioc, M. (2010). The Accountability of European Agencies. Legal Provisions and Ongoing Practices. Delft, Eburon.

Busuioc (2010b)

Busuioc, M. (2010). European Agencies: Pockets of Accountability. The Real World of EU Accountability: What Deficit? M. A. P. Bovens, D. M. Curtin and P. 't Hart. New York, Oxford University Press: 87-116.

Busuioc (2009)

Busuioc, M. (2009). 'Accountability, Control and Independence: The Case of European Agencies.' European Law Journal 15(5): 599-615.

Castle (1996)

Castle, S. (1996). Major tells Euro-MPs: 'Go boil your heads' The Independent.

Chalmers/Monti (2008)

Chalmers, D. and G. Monti (2008). European Union law: text and materials: updating supplement. Cambridge etc., Cambridge University Press.

Chalmers (2006)

Chalmers, D. (2006). European Union law: text and materials. Cambridge etc., Cambridge University Press.

Chambers (1999)

Chambers, G. R. (1999). The BSE crisis and the European Parliament. EU Committees: Social regulation, law and politics. C. Joerges and E. Vos. Oxford, etc., Hart: 95-106.

Clegg/Van Hulten (2004)

Clegg, N. and M. Van Hulten (2004). 'Reforming the European Parliament.' Online available under: http://fpc.org.uk/fsblob/130.pdf.

Committee of Independent Experts (1999a)

Committee of Independent Experts (1999). First Report on Allegations regarding Fraud, Mismanagement and Nepotism in the European Commission.

Committee of Independent Experts (1999b)

Committee of Independent Experts (1999). Second report on Reform of the Commission. Analysis of current practice and proposals for tackling mismanagement, irregularities and fraud (Volume I). 
Committee of Independent Experts (1999c)

Committee of Independent Experts (1999). Second report on Reform of the Commission. Analysis of current practice and proposals for tackling mismanagement, irregularities and fraud (Volume II).

Corbett/Jacobs/Shackleton (2011)

Corbett, R., F. Jacobs, M. Shackleton (2011). The European Parliament. London, John Harper Publishing.

Corbett/Jacobs/Shackleton (2007)

Corbett, R., F. Jacobs, M. Shackleton (2007). The European Parliament. London, John Harper Publishing.

Costa (2001)

Costa, O. (2001). Le Parlement européen, assemblée délibérante. Bruxelles, Editions de l'Université de Bruxelles.

Council of Europe Parliamentary Assembly (2006). Committee on Legal Affairs and Human Rights. Alleged secret detentions in Council of Europe Member States (22.1.2006).

Council of Ministers (1994). Proposal of the Council on parliamentary committees of inquiry (SN 1338/94, 3.2.1994).

Craig/De Búrca (2011)

Craig, P. and G. de Búrca (2011). EU law: text, cases, and materials. Oxford etc., Oxford University Press.

Craig (2000)

Craig, P. (2000). 'The Fall and Renewal of the Commission: Accountability, Contract and Administrative Organisation.' European Law Journal 6(2): 98116.

Crosbie (2008)

Crosbie, J. (2008). MEPs split over launch of another CIA report. European Voice.

\section{Curtin (2009)}

Curtin, D. M. (2009). Executive Power of the European Union; Law, Practices, and the Living Constitution. Oxford, Oxford University Press.

\section{Curtin (2004)}

Curtin, D. M. (2004). Mind the Gap: The Evolving EU Executive and the Constitution. Groningen, Europa Law Publishing.

Dehousse (2008)

Dehousse, R. (2008). 'Delegation of powers in the European Union: the need for a multi-principals model.' West European Politics 4: 789-805. 
De Witte (2008)

De Witte, B. (2008). Legal Instruments and Law-Making in the Lisbon Treaty. The Lisbon Treaty: EU Constitutionalism Without a Constitutional Treaty? S. Griller and J. Ziller. Wien - New York, Springer Verlag: 79-108.

De Witte (1995)

De Witte, B. (1995). Interpreting the EC Treaty like a constitution: the role of the European Court of Justice in comparative perspective. Judicial control: comparative essays on judicial review. R. Bakker, A. W. Heringa and F. A. M. Stroink. Antwerpen - Apeldoorn, MAKLU Uitgevers.

Driessen (2007)

Driessen, B. (2007). Interinstitutional Conventions in EU Law. London, Cameron May Ltd.

Editorial Comment, Common Market Law Review (1999)

Editorial Comment (1999). Common Market Law Review 36: 269-272.

European Commission (2008). Green Paper on Consumer Collective Redress (COM/2008/794, 27.11.2008).

European Commission (2006). A strategic review of Better Regulation in the European Union (COM/2006/689, 14.11.2006).

European Commission (2005). Third package of legislative measures on maritime safety in the European Union (COM/2005/585, 23.11.2005).

European Commission (2001). European Governance: A White Paper (COM/2001/428, 25.7.2001).

European Commission (2000). Reforming the Commission: A White paper, Part I (COM/2000/200, 5.4.2000).

European Commission (1997). Action plan for transit in Europe - a new customs policy (OJ C 176, 10.6.1997).

European Commission (1995). Fraud in the Transit Procedure, Solutions Foreseen and Perspectives for the Future (COM/95/108, 29.03.1995).

European Commission (1993). Growth, competitiveness, and employment. The challenges and ways forward into the 21st century (COM /93/700, 05.12.1993).

European Court of Auditors (2006). Special Report No. 11/2006 on the Community transit system, together with the Commission's replies (OJ C 44, 27.2.2007).

European Court of Auditors (1995). Annual Report for 1994 (OJ C 303, 14.11.1995). 
European Ombudsman (2000). Annual Report for 1999 (1.4.2000).

European Ombudsman (1996). Annual Report for 1995 (22.4.1996).

European Parliament (2012). CONT committee. Report on discharge in respect of the implementation of the budget of the European Medicines Agency for the financial year 2010 (A7-0107/2012, 4.4.2012).

European Parliament (2011). AFCO committee. Report on a proposal for a regulation of the European Parliament on the detailed provisions governing the exercise of the European Parliament's right of inquiry and repealing Decision 95/167/EC, Euratom, ECSC of the European Parliament, the Council and the Commission (A7-0352/2011, 14.10.2011).

European Parliament (2011). CONT committee. Second report on discharge in respect of the implementation of the budget of the European Police College for the financial year 2009 (A7-0330/2011, 6.10.2011).

European Parliament (2011). PETI committee. Annual report of the Petitions committee 2010 (A7-0232/2011, 17.6.2011).

European Parliament (2011). Committee on the financial, economic and social crisis. Report on the financial, economic and social crisis: recommendations concerning the measures and initiatives to be taken (A7-0228/2011, 14.6.2011).

European Parliament (2011). Committee on Policy Challenges and Budgetary Resources for a Sustainable European Union after 2013. Report on Investing in the future: a new Multiannual Financial Framework (MFF) for a competitive, sustainable and inclusive Europe (A7-0193/2011, 26.5.2011).

European Parliament (2011). ENVI committee. Report on EU legislation on Transmissible Spongiform Encephalopathies (TSE) and on related feed and food controls - implementation and outlook (A7-0195/2011, 26.5.2011).

European Parliament (2011). CONT committee. Report on discharge in respect of the implementation of the budget of the European Medicines Agency for the financial year 2009 (A7-0153/2011, 15.4.2011).

European Parliament (2011). CONT committee. Report on discharge in respect of the implementation of the general budget of the European Union for the financial year 2009, Section III - Commission and executive agencies (A70134/2011, 14.4.2011).

European Parliament (2011). ENVI committee. Report on evaluation of the management of $\mathrm{H}_{1 \mathrm{~N}} 1$ influenza in 2009-2010 in the EU (A7-0035/2011, 9.2.2011). 
European Parliament (2010). ENVI committee. Report on the implementation of EU legislation aiming at the conservation of biodiversity (A7-0241/2010, 25.8.2010).

European Parliament (2010). PETI committee. Annual report of the Petitions committee 2009 (A7-0186/2010, 7.6.2010).

European Parliament (2010). CONT committee. Report on discharge in respect of the implementation of the European Union general budget for the financial year 2008, Section III - Commission and executive agencies (A7-0099/2010, 26.3.2010).

European Parliament (2010). CONT committee. Report on discharge in respect of the implementation of the budget of the European Police College for the financial year 2008 (A7-0075/2010, 26.3.2010).

European Parliament (2009). CONT committee. Handbook 2009 for New Members of the Committee on Budgetary Control (June 2009).

European Parliament (2009). PETI committee. Annual report of the Petitions committee 2008 (A6-0232/2009, 3.4.2009).

European Parliament (2009). Working party on parliamentary reform. Third Interim Report on Committees and Delegations (PE 417.163/CPG/GT/Ann, 26.3.2009).

European Parliament (2008). Climate Change Committee. Report on '2050: The future begins today - Recommendations for the EU's future integrated policy on climate change' (A6-0495/2008, 10.12.2008).

European Parliament (2008). Working party on parliamentary reform. Second Interim Report on Legislative Activities and Interinstitutional Relations (Part B, PE 406.309/CPG/GT/B, 15.5.2008).

European Parliament (2007). PETI committee. Report on the Fact Finding Mission to Poland 'Via Baltica' (Warszawa-Bialystok-Augustow) (PE 376.717, 16.7.2007).

European Parliament (2007). Equitable Life committee. Report on the crisis of the Equitable Life Assurance Society. Final Report (A6-0203/2007, 23.5.2007).

European Parliament (2007). AFCO committee. Parliamentary committees of inquiry: a survey (31.1.2007).

European Parliament (2007). CIA Flights committee. Report on the alleged use of European countries by the CIA for the transportation and illegal detention of prisoners (A6-0020/2007, 30.1.2007). 
European Parliament (2006). CIA Flights committee. Notice to members (376.444, 5.7.2006).

European Parliament (2006). CIA Flights committee. Working document No 2 on a chronology of events (PE 374.338, 1.6.2006).

European Parliament (2006). Equitable Life Committee. Working document on lines of action arising from mandate for inquiry into the collapse of Equitable Life Assurance Society (2006/2026 (INI), 9.3.2006).

European Parliament (2006). CIA Flights committee. Working document on TDIP Temporary Committee work programme (PE 370.642, 14.2.2006).

European Parliament (2004). PCBM committee. Working document (no. 2) on the financial perspective 2007-2013: state of play (PE 349.838, 21 October 2004).

European Parliament (2004). PCBM committee. Working document (no. 1) on the organisation and working methods (PE 349.837, 21 October 2004).

European Parliament (2004). Committee on Improving Safety at Sea. Report on improving safety at sea (A5-0257/2004, 7.4.2004).

European Parliament (2002). FMD committee. Activity report (PE 319.300, 19.12.2002).

European Parliament (2002). FMD committee. Report on measures to control Foot and Mouth Disease in the European Union in 2001 and future measures to prevent and control animal diseases in the European Union (A5-0405/2002, 28.11.2002).

European Parliament (2001). Human Genetics committee. Report on the ethical, legal, economic and social implications of human genetics (A50391/2001, 8.11.2001).

European Parliament (2001). Echelon committee. Report on the existence of a global system for the interception of private and commercial communications (ECHELON interception system) (Part 1, A5-0264/2001, 11.7.2001).

European Parliament (2001). Echelon committee. Report on the existence of a global system for the interception of private and commercial communications (ECHELON interception system) (Part 2, A5-0264/2001, 11.7.2001).

European Parliament (2001). Echelon committee. Working document in preparation for a report on the existence of a global system for intercepting private and commercial communications (ECHELON interception system) (PE $300.153,4.5 .2001)$. 
European Parliament (1998). CONT committee. Report on postponement of the discharge to be given to the Commission in respect of the implementation of the general budget of the European Community for the 1996 financial year (A4-0097/98, 18.3.1998).

European Parliament (1997). BSE follow-up committee. Report on the European Commission's follow-up of the recommendations made by the committee of inquiry into BSE (A4-0362/97, 14.11.1997).

European Parliament (1997). Transit committee. Chairman's report on the working methods of the Committee of Inquiry into the Community Transit System (PE 220.696/rev., 21.2.1997).

European Parliament (1997). Transit committee. Report on the Community Transit System (Volume I, A4-0053/97, 20.2.1997).

European Parliament (1997). Transit committee. Report on the Community Transit System (Volume II, A4-0053/97, 20.2.1997).

European Parliament (1997). Transit committee. Report on the Community Transit System (Volume III, A4-0053/97, 20.2.1997).

European Parliament (1997). BSE committee. Report on alleged contraventions or maladministration in the implementation of Community law in relation to BSE (Part AI and AII, A4-0020/97/A, 7.2.1997).

European Parliament (1997). BSE committee. Report on alleged contraventions or maladministration in the implementation of Community law in relation to BSE (Part AIII, A4-0020/97/AIII, 7.2.1997).

European Parliament (1997). BSE committee. Report on alleged contraventions or maladministration in the implementation of Community law in relation to $\mathrm{BSE}$ (Part B, A4-0020/97/B, 7.2.1997).

European Parliament (1997). BSE committee. Report on alleged contraventions or maladministration in the implementation of Community law in relation to BSE (Part C, A4-0020/97/C, 7.2.1997).

European Parliament (1997). BSE committee. Chairman's observations on institutional aspects of the work of the committee of inquiry (PE 220.853, 7.1.1997).

European Parliament (1995). Committee on Institutional Affairs. Report on the right of inquiry of the European Parliament (A4-0003/95, 12.1.1995).

European Parliament (1995). Temporary committee on Employment. Report on a coherent employment strategy for the European Union (A4-0166/95, 28.6.1995). 
European Parliament (1992). Proposal of the European Parliament on parliamentary committees of inquiry (A3-0302/O2, OJ C 21, 25.1.92, pp. 147$151)$.

European Parliament (1986). Working document incorporating proposed amendments to the Rules of Procedure concerning committees of inquiry (A2$100 / 86,15.8 .1986)$.

European Parliament (1982). Working document on the interpretation of Rule 95 of the Rules of Procedure (PE 80.257, 3.9.1982).

Fisher (2004)

Fisher, E. (2004). 'The European Union in the Age of Accountability.' Oxford Journal of Legal Studies: 24(3).

Follesdal/Hix (2005)

Follesdal, A. and S. Hix (2005). 'Why There is a Democratic Deficit in the EU: A Response to Majone and Moravcsik.' European Governance Papers $($ EUROGOV)(C-05-02): 1-27.

Goebbels (2001)

Goebbels, R. (2001). Conference: Stem cells: therapies for the future?, Brussels, 18-19 december 2001. Online available under: http://ec.europa.eu/research/quality-of-life/stemcells/pro_goebbels2_en.html.

Harlow/Rawlings (2007)

Harlow, C. and R. Rawlings (2007). 'Promoting Accountability in Multilevel Governance: A Network Approach.’ European Law Journal 13(4): 542-562.

Harlow (2002)

Harlow, C. (2002). Accountability in the European Union. Oxford etc., Oxford University.

Hix (2005)

Hix, S. (2005). The political system of the European Union. Basingstoke etc., Palgrave Mac.

Höpfner (2004)

Höpfner, S. (2004). Parlamentarische Kontrolle in Deutschland und in der Europäischen Union: das Recht der parlamentarischen Untersuchungsausschüsse des Deutschen Bundestages und des Europäischen Parlaments. Hamburg, Kovac.

Hummer (2007)

Hummer, W. (2007). 'From 'Interinstitutional Agreements' to 'Interinstitutional Agencies/Offices'?' European Law Journal 13(1): 47-74. millan. 
Jabko (2003)

Jabko, N. (2003). 'Democracy in the age of the Euro.' Journal of European Public Policy 10(5): 710-739.

Jacqué (2004)

Jacqué, J.-P. (2004). 'The principle of institutional balance.' Common Market Law Review 41: 383-391.

Jones (2008)

Jones, R. (2008). EU pressure on Brown over Equitable row. The Guardian.

Jones (2005)

Jones, R. (2005). Equitable Life victims given new hope with European inquiry. The Guardian.

\section{Judge/Earnshaw (2008)}

Judge, D. and D. Earnshaw (2008). The European Parliament. Basingstoke, Palgrave Macmillan

Judge/Earnshaw (2002)

Judge, D. and D. Earnshaw (2002). "The European Parliament and the Commission Crisis: A New Assertiveness?' Governance 15(3): 345-374.

Lenaerts/Verhoeven (2002)

Lenaerts, K. and A. Verhoeven (2002). Institutional balance as a guarantee for democracy in EU governance. Good governance in Europe's integrated market. C. Joerges and R. Dehousse. Oxford ; New York, Oxford University Press: 3588.

Lequesne/Rivaud (2003)

Lequesne, C. and P. Rivaud (2003). 'The Committees of Independent Experts: expertise in the service of democracy?' Journal of European Public Policy 10(5): 695-709.

Lord (2004)

Lord, C. (2004). A Democratic Audit of the European Union. Basingstoke, Palgrave Macmillan.

Lord (2001)

Lord, C. (2001). 'Assessing Democracy in a Contested Polity.' Journal of Common Market Studies 39(4): 641-661.

Lord (2000)

Lord, C. (2000) 'Legitimacy, Democracy and the EU: when abstract questions become practical policy problems'. Policy Paper 03/00. 
Majone (2006)

Majone, G. (2006). 'The Common Sense of European Integration.' Journal of European Public Policy 13(5): 607-626.

Majone (2005)

Majone, G. (2005). Dilemmas of European integration. Oxford, Oxford University Press.

Mann (1997)

Mann, M. (1997). 'Euro MPs pull no punches in BSE inquiry.' European Voice.

Maurer (2007)

Maurer, A. (2007). The European Parliament between Policy-Making and Control. Debating the democratic legitimacy of the European Union. B. Kohler-Koch and B. Rittberger. Lanham, Rowman \& Littlefield: 75-101.

Mehde (2009)

Mehde, V. (2009). Political Accountability in Europe. Political Accountability and European Integration. L. F. M. Verhey, P. Kiiver and S. C. Loeffen. Groningen, Europa Law Publishing: 73-77.

Monar (1994)

Monar, J. (1994). 'Interinstitutional Agreements: The Phenomenon and its New Dynamics after Maastricht.' Common Market Law Review 31: 693-719.

Mulgan (2000)

Mulgan, R. (2000). 'Accountability': An ever-expanding concept?' Public Administration 78(3): 555-573.

Nugent (2001)

Nugent, N. (2001). The European Commission, Palgrave Macmillan.

Oliver (2003)

Oliver, D. (2003). Constitutional reform in the United Kingdom. Oxford etc., Oxford University Press.

Papadopoulos (2007)

Papadopoulos, Y. (2007). 'Problems of Democratic Accountability in Network and Multilevel Governance.' European Law Journal 13(4): 469-486.

Phillips (2010)

Phillips, L. (2010). Parliament freezes EU Police College funds over dodgy accounts. EUobserver.

Priestley (2008)

Priestley, J. (2008). Six battles that shaped Europe's Parliament. London, John Harper Publishing. 
Rittberger (2005)

Rittberger, B. (2005). Building Europe's parliament: democratic representation beyond the nation-state. Oxford etc., Oxford University Press.

Roxburgh (2001)

Roxburgh, A. (2001). EU investigators 'snubbed' in US. BBC News. Online available under: http://news.bbc.co.uk/2/hi/europe/1325186.stm.

Scott (2000)

Scott, C. (2000). 'Accountability in the regulatory state.' Journal of Law and Society 27(1): 38-60.

Scharpf (1999)

Scharpf, F. (1999). Governing in Europe: Effective and Democratic? Oxford, Oxford University Press.

Schmitter (2000)

Schmitter, P. C. (2000). How to Democratize the European Union...and Why Bother? Lanham, Rowman \& Littlefield.

Scholten (2010)

Scholten, M. O. (2010). What If the European Parliament Says 'No'?: The Strength of European Parliament's Discharge Power. Online available under: http://ssrn.com/abstract=1909450.

Schulte (2003)

Schulte, M. (2003). 'Das Recht der Untersuchungsausschüsse.' Jura 8: 505-512.

Sebag (2012)

Sebag, G. (2012). EP tries to drive wedge between Council and Commission. Europolitics. Online available under: http://www.europolitics.info/ep-tries-todrive-wedge-between-council-and-commission-art333149-32.html.

Senden (2003)

Senden, L. (2003). Soft law in European Community law. Oxford, Hart Publishing Ltd.

\section{Senden (2005)}

Senden, L. (2005). 'Soft Law, Self-Regulation and Co-Regulation in European Law: Where Do They Meet?' Electronic Journal of Comparative Law 9.1: 1-27.

Shackleton (1998)

Shackleton, M. (1998). 'The European Parliaments New Committees of Inquiry: Tiger or Paper Tiger?' Journal of Common Market Studies 36(1): 115130. 
Shapiro (1998)

Shapiro, M. (1998). The Politics of Information: US Congress and European Parliament. Lawmaking in the European Union. P. P. Craig and C. Harlow. London, Kluwer Law International.

Strøm (2003)

Strøm, K. (2003). Delegation and accountability in parliamentary democracies. Oxford etc., Oxford University Press.

Tomkins (1999)

Tomkins, A. (1999). 'Responsibility and Resignation in the European Commission.' The Modern Law Review 62(5): 744-765.

Van de Steeg (2010)

Van de Steeg, M. (2010). The European Council's Evolving Political Accountability. The Real World of EU Accountability. M. A. P. Bovens, D. M. Curtin and P. 't Hart. Oxford; New York, Oxford University Press: 117-149.

\section{Van Gerven (2009)}

Van Gerven, W. (2009). Some Remarks Concerning Commissioners. Political Accountability and European Integration. L. F. M. Verhey, P. Kiiver and S. C. Loeffen. Groningen, Europa Law Publishing: 115-123.

\section{Verhey/Claes (2008)}

Verhey, L. F. M. and M. L. H. K. Claes (2008). Introduction: Political Accountability in a European Perspective. Political Accountability in Europe: Which Way Forward? A Traditional Concept of Parliamentary Democracy in an EU Context. L. F. M. Verhey, J. L. W. Broeksteeg and I. A. Van den Driessche. Groningen, Europa Law Publishing: 1-23.

Verhey/Claes/Broeksteeg (2008)

Verhey, L. F. M., M. L. H. K. Claes, et al. (2008). Political Accountability in the European Union: Conceptual Analysis and Future Prospects. Political Accountability in Europe: Which Way Forward? A Traditional Concept of Parliamentary Democracy in an EU Context. L. F. M. Verhey, J. L. W. Broeksteeg and I. A. Van den Driessche. Groningen, Europa Law Publishing: 299-338.

\section{Vos (2003)}

Vos, E. (2003). Agencies and the European Union. Agencies in European and Comparative Law. T. Zwart and L. F. M. Verhey. Antwerpen - Oxford - New York, Intersentia: 113-148.

\section{Vos (2000)}

Vos, E. (2000). 'EU Food Safety Regulation in the Aftermath of the BSE Crisis.' Journal of Consumer Policy 23: 227-255. 
Weatherill/Beaumont (1999)

Weatherill, S. and P. Beaumont (1999). EU Law. London, Penguin Books.

Westlake (1997)

Westlake, M. (1997). 'Mad Cows and Englishmen' - The Institutional Consequences of the BSE Crisis.' Journal of Common Market Studies 35: 11-36.

Westlake (1994)

Westlake, M. (1994). The Commission and the Parliament: Partners and Rivals in the European Policy-Making Process. London, Butterworths.

Wiersma (2004)

Wiersma, J. M. (2004). 'De parlementaire enquête op z'n Brussels.' Nederlands Juristenblad 5: 225-228.

Wiersma/Van de Water (2001)

Wiersma, J. M. and R. Van de Water (2001). Spionage in het hoogste Echelon. Amsterdam, Podium.

Wille (2010)

Wille, A. (2010). The European Commission's Accountability Paradox. The Real World of EU Accountability. M. A. P. Bovens, D. M. Curtin and P. 't Hart. Oxford; New York, Oxford University Press: 63-86.

Woolsey (2000)

Woolsey, J. R. (2000). Why We Spy on Our Allies. Wall Street Journal.

Wurzel (1999)

Wurzel, R. (1999). 'The Role of the European Parliament: Interview with Ken Collins MEP.' The Journal of Legislative Studies 5(2): 1-23. 


\section{CURRICULUM VITAE}

Christian Syrier was born on 11 December 1983 in Maastricht. While studying law at Maastricht University (2002-2007) he worked as a junior court clerk at the District Court of Maastricht and was an intern at the Directorate of Legislation of the Dutch Ministry of Justice in The Hague. After obtaining his degree in Dutch law, with a specialisation in constitutional and administrative law, he took several courses in German constitutional law at the Humboldt University of Berlin. From 2008 to 2012 he worked as a junior researcher at the law faculty of Maastricht University. Besides writing his doctoral thesis, he taught several courses in the field of constitutional and administrative law, was a member of the central electoral committee of Maastricht University (20082011), and was a secretary on the editorial staff of the legal periodical European Human Rights Cases (2008-2010). From May to September 2010 he was a visiting scholar at the 'Verfassung jenseits des Staates' graduate school at the Humboldt University in Berlin. He has worked as a legal counsel at the Directorate of Legislation of the Dutch Ministry of Security and Justice in The Hague since April 2012. 